EDUARDO PESSOA NOCETTI CROITOR

A GESTÃO DE PROJETOS APLICADA À REABILITAÇÃO DE EDIFÍCIOS: ESTUDO DA INTERFACE ENTRE PROJETO E OBRA

São Paulo 
EDUARDO PESSOA NOCETTI CROITOR

\section{A GESTÃO DE PROJETOS APLICADA À REABILITAÇÃO DE EDIFÍCIOS: ESTUDO DA INTERFACE ENTRE PROJETO E OBRA}

Dissertação apresentada à Escola Politécnica da Universidade de São Paulo para obtenção do título de Mestre em Engenharia.

Área de Concentração:

Engenharia de Construção Civil e Urbana

Orientador:

Prof. Dr. Silvio Burrattino Melhado

São Paulo

2008 
EDUARDO PESSOA NOCETTI CROITOR

\section{A GESTÃO DE PROJETOS APLICADA À REABILITAÇÃO DE EDIFÍCIOS: ESTUDO DA INTERFACE ENTRE PROJETO E OBRA}

Dissertação apresentada à Escola Politécnica da Universidade de São Paulo para obtenção do título de Mestre em Engenharia.

Área de Concentração:

Engenharia de Construção Civil e Urbana

Orientador:

Prof. Dr. Silvio Burrattino Melhado

São Paulo 


\section{FICHA CATALOGRÁFICA}

Croitor, Eduardo Pessoa Nocetti

A gestão de projetos aplicada à reabilitação de edifícios : estudo da interface entre projeto e obra / E.P.N. Croitor. -- São Paulo, 2008.

$176 \mathrm{p}$.

Dissertação (Mestrado) - Escola Politécnica da Universidade de São Paulo. Departamento de Engenharia de Construção Civil.

1. Edifícios (Reabilitação) 2. Administração de projetos I. Universidade de São Paulo. Escola Politécnica. Departamento de Engenharia de Construção Civil II. t. 


\section{DEDICATÓRIA}

À Lulu, meu amor,

que me inspira com sua alegria e me faz entender e sentir o amor. 


\section{AGRADECIMENTOS}

À Luciana, minha esposa, pela amizade, companheirismo, tolerância etc. À minha querida amiga, Luciana Oliveira, pela sua imensa generosidade, carinho e estímulo.

Às amadas Sylvia e Déborah, e elas sabem bem o porquê.

Ao prof. Silvio Melhado, pela orientação e paciência nesses anos. À profa. Mércia e ao prof. Qualharini, que foram essenciais para o amadurecimento deste trabalho. Aos professores do PCC, em especial aos prof. Francisco Cardoso e Ubiraci Espinelli.

Às empresas que abriram suas portas para a elaboração dos estudos de caso: Tecnisa, CDHU e Pierre Nallet.

Aos amigos: Josmária e Sidnei, pela injeção de ânimo na reta final deste trabalho; Ércio e Cláudio Mitidieri, que me ensinaram a amar ainda mais a Engenharia.

Ao meu pai, Jair Croitor, pela sua habilidade de me impulsionar em meus projetos pessoais; e à minha família, que eu amo tanto. 


\section{RESUMO}

$\mathrm{Na}$ construção civil, de uma forma geral, a gestão de projetos pode contribuir positivamente com resultados de um empreendimento. Entretanto, ao longo do desenvolvimento desta pesquisa, constatou-se que a gestão de projetos pode ser ainda mais relevante nos processos de reabilitação de edifícios.

Naturalmente, os níveis de complexidade da reabilitação variam conforme o grau de intervenção que se deseja, o que influenciará a formatação do modelo mais adequado de gestão do empreendimento. Mas a organização do empreendimento, sempre que baseada em princípios de gestão de projetos adequados, pode contribuir para a estabilidade no canteiro e para que haja condições que promovam harmonia na relação entre os agentes envolvidos, principalmente entre as equipes de projeto e de obra.

O presente trabalho se propõe a aprofundar a discussão sobre essas questões, apresentando os resultados de uma pesquisa bibliográfica sobre o assunto que busca caracterizar os empreendimentos de reabilitação, as interfaces entre projeto e obra, além de discutir o papel da coordenação de projetos no contexto da reabilitação de edifícios. Serão apresentados, ainda, os resultados das pesquisas de campo realizadas em dois empreendimentos de reabilitação: dois em São Paulo, Brasil e, um outro, na cidade de Lyon, na França.

Palavras-chave: gestão de projetos, reabilitação, retrofit, interface projeto - obra. 


\begin{abstract}
In civil construction the management of design may positively contribute to the results of an enterprise in general way. However, throughout the development of this research, we realize that the management of designs can be much more relevant in building rehabilitation.

Of course, the levels of complexity in rehabilitation process vary according to the grade of intervention desired and this affects the formatting of a more adequate model of the enterprise management. Management of designs, whenever it is based on appropriate principles and methods, may contribute to the results at the building site in order to provide a balanced relationship among the agents involved, mainly between the two groups responsible for the designs and its carrying out.

This work intends to go deeper into the discussion of these issues by presenting the results of a bibliographical research on the matter, to mark the enterprises in rehabilitation, interfaces between design and work, and to discuss the role coordination of designs plays in the building rehabilitation context. Besides this, it shows the results of field surveys carried out in two rehabilitation enterprises in São Paulo-Brazil and one in Lyon-France.
\end{abstract}

Key words: design management, rehabilitation, retrofit. 


\section{LISTA DE FIGURAS}

Figura 1 - Reabilitação de edifício na cidade de Paris, França (arquivo do autor) .....2 Figura 2 - Evolução dos investimentos na construção civil na Áustria

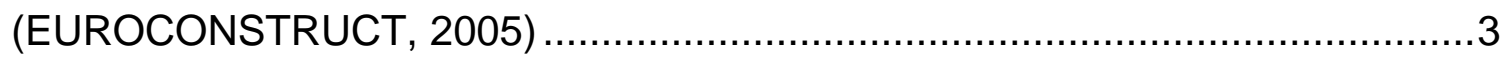

Figura 3 - Agentes envolvidos no processo de reabilitação de edificações (adaptado

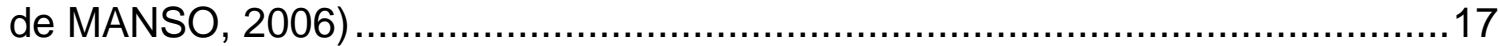

Figura 4 - Edificação localizada no centro de São Paulo, com sinais evidentes de degradação (arquivo do autor) 20

Figura 5 - Desempenho de um edifício comercial (adaptado de CUSHMAN \& WAKEFIELD SEMCO, 2005)

Figura 6 - Migração dos investimentos no mercado de edifícios comerciais de escritórios da cidade de São Paulo, SP (adaptado de CUSHMAN \& WAKEFIELD SEMCO, 2005)

Figura 7 - Condomínio residencial localizado na cidade de Osasco - SP: obra inacabada e abandonada (arquivo do autor).

Figura 8 - Nova central de ar condicionado com termoacumulação da Bolsa de Mercadoria e Futuros, no centro da cidade de São Paulo (Revista Téchne n46)

Figura 9 - Edifício Wilson Mendes Caldeira, localizado na Av. Nações Unidas - São

Paulo 28

Figura 10 - Antiga fábrica têxtil convertida em hipermercado na cidade de São

Paulo, SP (arquivo do autor) 32

Figura 11 - Revestimento danificado devido à infiltração de água pela cobertura....34

Figura 12 - Modelo de processo de projeto para reabiliação (adaptado de Roders, 2006).

Figura 13 - Esquema da relação dos intervenientes nas diferentes fases do processo de reabilitação (FREITAS e SOUSA, 2003) ..... 45

Figura 14 - Instalação hidráulica adaptada em edifício, na cidade de Lyon, França (arquivo do autor) 48

Figura 15 - Atividades da etapa de diagnóstico (BARRIENTOS, 2004). 52

Figura 16 - Canteiros e acessos em edifícios antigos em São Paulo-SP e Veneza, Itália (arquivo do autor) 
Figura 17 - Modelo de processo de projeto para reabilitação (adaptado de Roders, 2006)

Figura 18 - Proposta para o processo de desenvolvimento do projeto com a ação de quatro participantes do empreendimento (adaptado de MELHADO, 1994) .......58

Figura 19 - Balancim elétrico instalado na fachada de edifício, na cidade de Nápoles, Itália (esq.) e "kit sanitário" na cidade de Florença, Itália (dir.) - arquivo do autor. 62

Figura 20 - À esquerda, vista inferior da laje: após início das obras de reabilitação se verificou a necessidade de executar a recuperação estrutural. À direita, sifonamento identificado após remoção do revestimento (arquivo do autor) .....66

Figura 21 - Canteiro de obras: índices para elaboração de orçamento mais preciso (arquivo do autor)

Figura 22 - Execução de serviços de reabilitação: pré-qualificação de fornecedores necessária (arquivo do autor).

Figura 23 - À esquerda, mapeamento das fachadas na etapa de diagnóstico. À direita, abertura de parede para nova parada de elevador (arquivo do autor) ...71

Figura 24 - Proposta de estruturação de equipe multidisciplinar envolvida no desenvolvimento do projeto (adaptado de MELHADO, 1994)

Figura 25 - Fachada dos fundos do Ed. Ana Cintra: antes (esq.) e após a reabilitação (dir.) - fonte: arquivo do autor

Figura 26 - Setores básicos de intervenção (SEADE-CDHU, 2002) 96

Figura 27 - Revestimento em mármore no piso da escadaria (esq.) e vista do hall de elevadores no pavimento térreo (dir.) - fonte: arquivo do autor 97

Figura 28 - Planta do projeto de reabilitação: $1^{\circ}$ ao $6^{\circ}$ pavimentos (fonte: $\mathrm{CDHU}$ )...98 Figura 29 - Planta do projeto de reabilitação: $7^{\circ}$ ao $10^{\circ}$ pavimentos (fonte: $\left.\mathrm{CDHU}\right) .99$

Figura 30 - Planta do projeto de reabilitação: $11^{\circ}$ pavimento (fonte: $\mathrm{CDHU}$ )..... .99

Figura 31 - Ciclos do empreendimento sob atuação da equipe de gestão do PAC (fonte: dados coletados junto à $\mathrm{CDHU}$ ) 100

Figura 32 - Cronologia dos eventos: projeto e execução das obras de reabilitação (fonte: dados coletados junto à $\mathrm{CDHU}$ ). 101

Figura 33 - Famílias do Movimento Sem-teto do Centro que ocuparam o Ed. Ana Cintra (CDHU-SGPAC, 2002) . 102

Figura 34 - Parte dos caixilhos e persianas de madeira foram substituídos caixilhos de PVC na reabilitação (dir.) - fonte: arquivo do autor 102 
Figura 35 - Materiais aplicados na edificação: reutilização descartada (esq.). Piso de taco de madeira e tijolos de barro removidos das paredes demolidas (dir.) fonte: arquivo do autor

Figura 36 - Vista parcial do $6^{\circ}$ pavimento após remoção do forro (esq.) e área de convivência sobre laje de cobertura do $6^{\circ}$ pav., executada na reabilitação (dir.) arquivo do autor

Figura 37- Remoção das instalações não prevista no projeto básico (esq.). À direita, medição individual do consumo de água dos apartamentos executada - arquivo do autor.

Figura 38 - Marcação de alvenaria (esq.) aguarda liberação para início da execução (dir) - fonte: arquivo do autor .....

Figura 39 - Ambiente com diferentes tipos de revestimentos antes da reabilitação (esq.). À direita, reaproveitamento do material é evidenciado na descontinuidade do piso (fonte: arquivo do autor)

Figura 40 - Piazza San Pietro antes (esq.) e após a reabilitação (dir.) - arquivo do autor

Figura 41 - Agentes envolvidos no início do empreendimento (dados coletados junto à Tecnisa)

Figura 42 - Ensaios de resistência (esq.) e de integridade dos elementos estruturais (dir.): verificação do projeto não foi realizada na etapa de estudo de viabilidade (arquivo do autor)

Figura 43 - Participação das diversas áreas da empresa para a elaboração do estudo de viabilidade (dados coletados junto à Tecnisa).

Figura 44 - Linha do tempo: paralisações e retomadas comprometem a padronização dos serviços e procedimentos (dados coletados junto à Tecnisa)

Figura 45 - Resíduo de demolição das alvenarias de vedação externas compactado e utilizado como sub-base para o piso da garagem (arquivo do autor). 122

Figura 46 - Fluxo de informações: interdependência entre as áreas de projeto e obra (dados coletados junto à Tecnisa)

Figura 47 - Painel com fotos dos serviços de recuperação estrutural: mudança de imagem do empreendimento no canteiro de obras da construtora (arquivo do autor)

Figura 48 - Criação de pilar na caixa de escadaria para aumentar a inércia do conjunto (arquivo do autor) 
Figura 49 - Execução de reforço estrutural nas vigas de periferia e lajes dos pavimentos (arquivo do autor)

Figura 50 - Reforço estrutural nas lajes sendo executado: arquivo do autor)

Figura 51 - Altura do pé-direito insuficiente em lances de escadaria (arquivo do autor)

Figura 52 - Aberturas executadas na laje para passagem de tubulações do sistema PEX: o projeto de reabilitação especificou utilização de tubulações de CPVC e PVC (arquivo do autor) 135

Figura 53 - Novos eletrodutos foram lançados no piso executado para o reforço estrutural das lajes (arquivo do autor).

Figura 54 - Integração Projeto x Obra: relacionamento próximo entre as áreas .....138 Figura 55 - Placa do empreendimento (esq.) e vista do edifício (dir.) -(arquivo do autor)

Figura 56 - Localização estratégica do empreendimento.

Figura 57 - Principais aspectos do estudo de viabilidade (dados coletados durante as entrevistas)

Figura 58 - Instalações originais substituídas (esq.). Instalações elétricas aparentes para evitar pontes de transferência entre os apartamentos (dir.) - arquivo do autor

Figura 59 - Novo pilar metálico instalado junto à estrutura existente (arquivo do autor).

Figura 60 - Principais agentes envolvidos no empreendimento (fonte: dados coletados durante as entrevistas) 150

Figura 61 - Caixilhos da fachada: substituição total (arquivo do autor) . 151

Figura 62 - Sistema de vedação interno em placas de gesso acartonado (esq.), inclusive na área da cozinha do apartamento (dir.) - arquivo do autor..... 152

Figura 63 - Casa de máquinas dos elevadores (arquivo do autor). 153

Figura 64 - Contraventamento das lajes para melhoria da estabilidade horizontal (arquivo do autor) 154

Figura 65 - Planta do pavimento térreo 155

Figura 66 - Tipologia "T1": 234 unidades com 23m² (esq.) 155

Figura 67 - Sistema de climatização instalado em todos os apartamentos (esq.). Boiler de aquecimento de água e tubulação hidro-sanitária aparente (dir.) arquivo do autor 
Figura 68 - Sistema de exaustão de fumaça acionado pelos detectores de fumaça. Abertura de captação de fumaça nos pavimentos (dir.) - arquivo do autor .....157 


\section{LISTA DE TABELAS}

Tabela 1 - Principais grupos de atributos para classificação de imóveis comerciais de NRE/POLI/USP (adaptado de WIAZOWSKI, 2007)

Tabela 2 - Custo de reabilitação x obra nova para HIS (adaptado de PROJETO REABILITA, 2007)

Tabela 3 - Exemplos de imóveis de uso comercial convertidos em habitação de interesse social, na cidade de São Paulo (adaptado de PROJETO REABILITA, 2005)

Tabela 4 - Empreendimentos residenciais convertidos em habitação de interesse social.

Tabela 5 - Principais diferenças na intervenção em edifícios comerciais e residenciais (adaptado de YOLLE, 2006)

Tabela 6 - Fases do processo de reabilitação (adaptado de PROJETO REABILITA, 2007).

Tabela 7 - Etapa técnica de viabilidade de um empreendimento (adaptado de

YOLLE, 2006)

Tabela 8 - Comparação de estrutura de orçamento de empreendimento de reabilitação voltado para HIS e obras "novas" (adaptado de Yolle, 2006) 68

Tabela 9 - Graus de intervenção de empreendimentos de reabilitação e a relação com a coordenação de projetos (adaptado de WIAZOWSKI, 2007).

Tabela 10 - Atividades de coordenação nas etapas de projeto (adaptado de

Melhado et al, 2005) continua

Tabela 11 - Atividades de coordenação nas etapas de projeto (adaptado de

Melhado et al, 2005) continuação

Tabela 12 - Atividades de coordenação nas etapas de projeto (adaptado de

Melhado et al, 2005) conclusão

Tabela 13 - Características das diferentes modalidades de coordenação de projetos

(adaptado de THOMAZ, 2001).

Tabela 14 - Competências e conhecimentos úteis para o desempenho da coordenação de projetos (MELHADO et al, 2005) . 89

Tabela 15 - Modelos de coordenação e suas vantagens potenciais (adaptado de

FABRICIO; MELHADO; GRILO, 2003) 
Tabela 17 - Alterações das soluções nas fases do projeto (dados coletados junto à

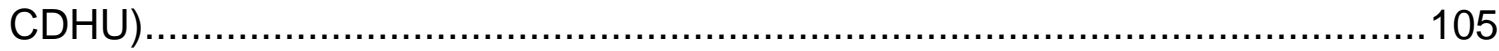

Tabela 18 - Mudanças de uso nas áreas externas do condomínio: 30 novos espaços de lazer e recreação (dados coletados junto à Tecnisa) 


\section{SUMÁRIO}

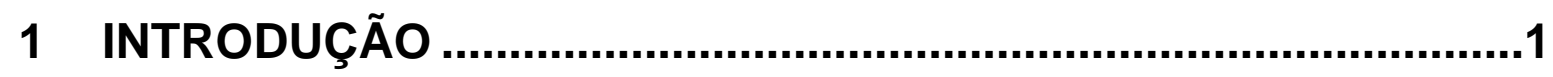

1.1 APRESENTAÇÃO DO TEMA E JUSTIFICATIVA ............................... 1

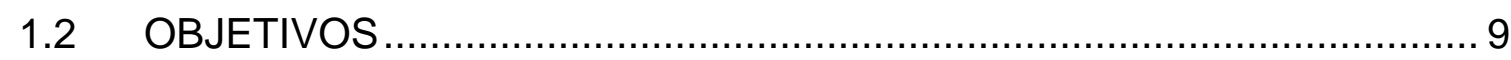

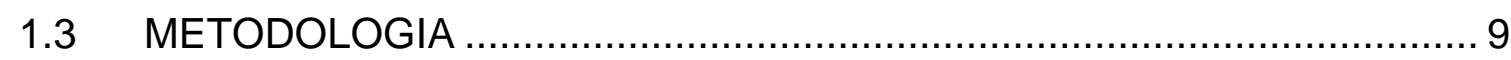

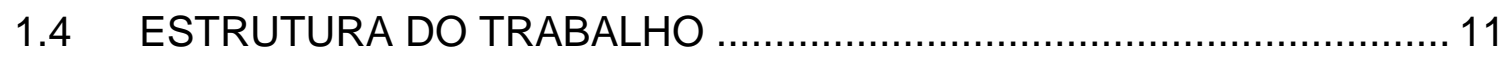

\section{CARACTERÍSTICAS DOS PROCESSOS DE REABILITAÇÃO..14}

2.1 REABILITAÇÃO DE EDIFICAÇÕES: CONCEITUAÇÃO ....................... 14

2.2 CAMPO DE APLICAÇÃO DA REABILITAÇÃO DE EDIFICAÇÕES ........ 16

2.2.1 Edificações antigas e degradadas ............................................. 18

2.2.2 Edificações inacabadas e abandonadas........................................ 23

2.2.3 Edificações com sistemas prediais ineficientes ou inadequados ..... 25

2.2.4 Reabilitação com mudança de uso ……….................................... 29

\section{ESTUDO DA INTERFACE PROJETO - OBRA EM}

EMPREENDIMENTOS DE REABILITAÇÃO DE EDIFÍCIOS

3.1 PROJETO E OBRA DE REABILITAÇÃO NO CONTEXTO

BRASILEIRO: MUDANÇA CULTURAL ..... 35

3.2 O PROCESSO DE PROJETO NA REABILITAÇÃO DE EDIFÍCIOS .......36

3.2.1 Etapa de investigação e diagnóstico............................................... 41

3.2.2 Etapas de desenvolvimento de projetos de reabilitação ...................56

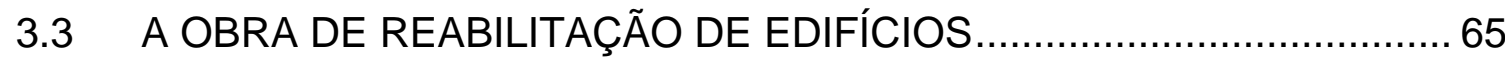




\section{A COORDENAÇÃO DE PROJETOS EM}

4.1 COORDENAÇÃO DE PROJETOS NA REABILITAÇÃO DE EDIFÍCIOS......

4.2 ATIVIDADES DE COORDENAÇÃO DE PROJETOS $\ldots \ldots \ldots \ldots \ldots \ldots \ldots \ldots . \ldots 77$

4.2.1 O perfil do coordenador de projetos.................................... 85

4.2.2 Modelos de coordenação de projetos ................................... 90

5 EXPERIÊNCIAS DE REABILITAÇÃO DE EDIFÍCIOS:

ESTUDOS DE CASO ....................................................................93

5.1 ESTUDO DE CASO 1: EDIFÍCIO ANA CINTRA (CENTRO - SÃO

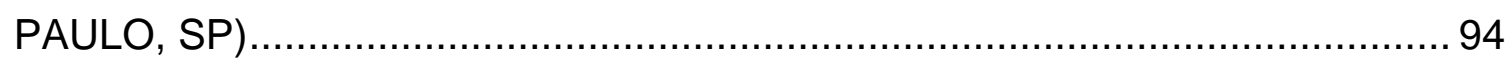

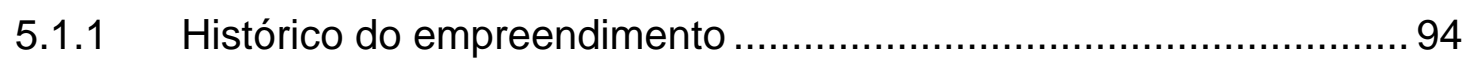

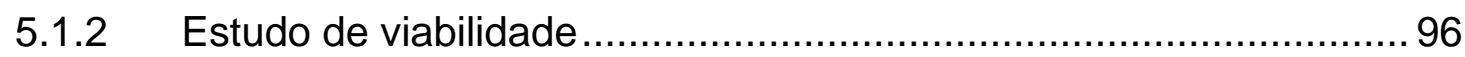

5.1.3 Caracterização do empreendimento ...................................... 97

5.1.4 Organização do empreendimento..................................... 100

Estado geral da edificação................................................. 101

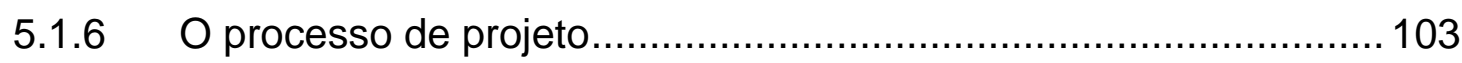

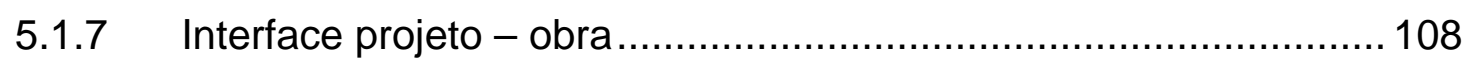

5.1.8 Lições aprendidas e comentários finais ................................ 111

5.2 ESTUDO DE CASO 2: CONDOMÍNIO PIAZZA SAN PIETRO

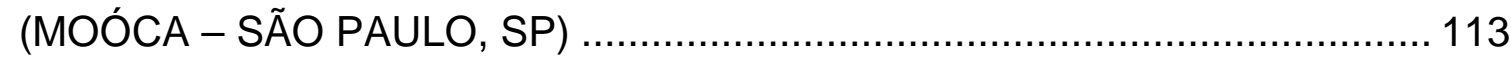

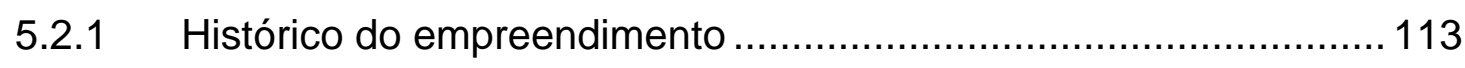

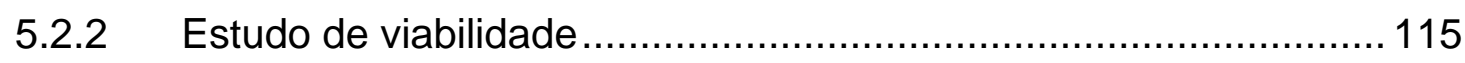

5.2.3 Caracterização do empreendimento .................................. 118

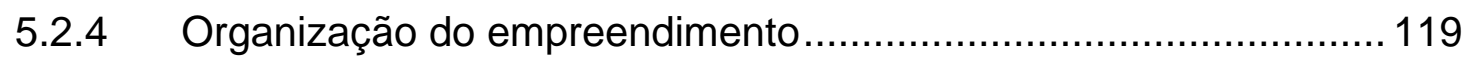

Estado geral da edificação .............................................. 120 
5.2.6 O processo de projeto.

5.2.7 Lições aprendidas e comentários finais ................................... 138

5.3 ESTUDO DE CASO 3: RÉSIDENCE PARK HERMÈS (LYON, PARIS) 142

5.3.1 Histórico do empreendimento ............................................ 142

5.3.2 Estudo de viabilidade ....................................................... 144

5.3.3 Caracterização do empreendimento ....................................... 147

5.3.4 Organização do empreendimento......................................... 149

Estado geral da edificação .............................................. 150

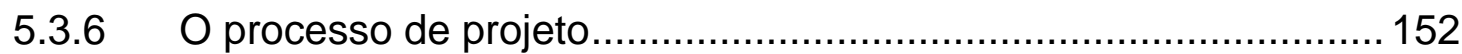

5.3.7 Lições aprendidas e comentários finais ................................. 157

6 CONSIDERAÇÕES FINAIS ................................................158

REFERÊNCIAS BIBLIOGRÁFICAS .............................................162

ANEXO A - Roteiro para entrevistas e visitas técnicas...............169 


\section{INTRODUÇÃO}

\subsection{APRESENTAÇÃO DO TEMA E JUSTIFICATIVA}

A reabilitação ${ }^{1}$ de edifícios é um assunto que está na pauta de discussões do setor da construção civil. A importância desse tema no contexto do mercado imobiliário da cidade de São Paulo, por exemplo, é, em parte, comprovada pelos seminários promovidos pelo SECOVI ${ }^{2}$, "Retrofit Vale a Pena!" realizado em 2005; pelo "II Congresso Internacional na Recuperação, Manutenção e Restauração de Edifícios" organizado pela Universidade Federal do Rio de Janeiro e Universidade Presbiteriana Mackenzie e pelo "Seminário Internacional de Reabilitação de Edifícios em Áreas Centrais", realizado na Escola Politécnica da USP pelo Projeto Reabilita, ambos em 2006. Além disso, o tema reabilitação de edifícios tem sido abordado com freqüência nas revistas técnicas especializadas ${ }^{3}$ e na imprensa de maneira geral.

As principais questões abordadas nessas oportunidades estão relacionadas a como se dá a gestão do processo de projeto de empreendimentos de reabilitação, às dificuldades encontradas na etapa de execução das obras, ao custo total de empreendimento de reabilitação, às linhas de financiamento, à necessidade de desenvolvimento de legislações específicas para este segmento de mercado, ao potencial e às demandas de mercado etc. Também são apresentadas soluções de projeto, sistemas e produtos aplicáveis à reabilitação de edifícios, estudos de viabilidade e casos práticos de reabilitação de edifícios no Brasil e no exterior.

Entretanto, as iniciativas voltadas à reabilitação no Brasil ainda não representam uma parcela significativa dos investimentos na construção civil, como é o caso de alguns países europeus.

\footnotetext{
${ }^{1}$ A definição dos termos reabilitação, requalificação, reforma e restauro podem ser encontradas no capítulo "2.1Reabilitação de edificações: conceituação".

${ }^{2}$ SECOVI - Sindicato das Empresas de Compra, Venda, Locação e Administração de Imóveis Residenciais e Comerciais de São Paulo.

${ }^{3}$ A edição do mês de maio da revista Téchne (edição 134) apresenta os casos de retrofit bem sucedidos realizados no Brasil e no exterior.
} 
Segundo o Euroconstruct (2006), o mercado de construção residencial foi responsável, somente nos países europeus, pela movimentação de 642 bilhões de euros, em 2005. Desse total, aproximadamente 302 bilhões de euros (47\%) foram aplicados em obras de reabilitação de edifícios residenciais. No universo da construção civil, as obras de reabilitação (Figura 1) representaram 36\% do volume de recursos aplicados em 2005.

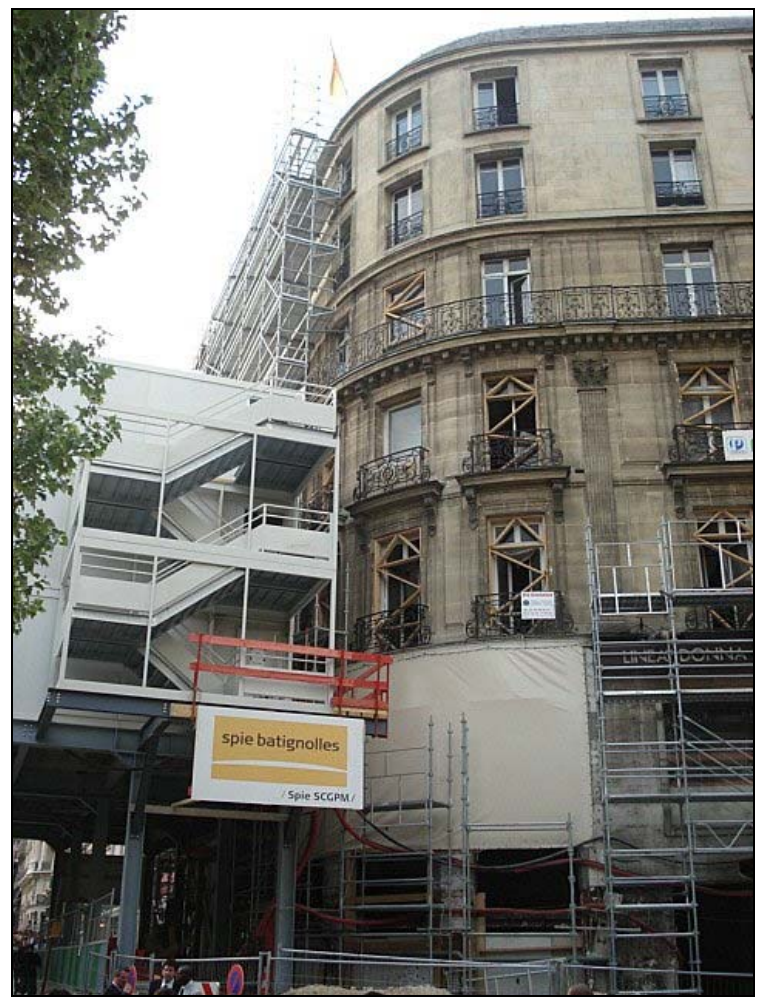

Figura 1 - Reabilitação de edifício na cidade de Paris, França (arquivo do autor)

O mesmo instituto europeu para a construção indica que o volume médio de investimentos em reabilitação de edifícios residenciais, na União Européia, se equipara ao aplicado em construções novas com a mesma funcionalidade. Países como França, Itália, Grã-Bretanha e Dinamarca destinam mais de 40\% do total de investimentos da construção civil em empreendimentos de reabilitação. 
Nas duas últimas décadas, segundo o documento Conservation... $(1999)^{4}$, os países europeus tem intensificado suas operações de reabilitação de edificações residenciais, comerciais e industriais. Mais econômica e eficiente do que a demolição seguida de uma reconstrução, este tipo de operação tem se proliferado nas cidades européias.

Embora a previsão de crescimento do investimento em reabilitação na União Européia, para o período 2008-2009, em construções não-residenciais seja menor do que em construções novas $(3,0 \% \text { ao ano })^{5}$, países, como a Áustria, continuam destinando uma parcela significativa dos investimentos para reabilitação de edifícios, indicada na Figura 2 com legenda "building renovation and modernisation".

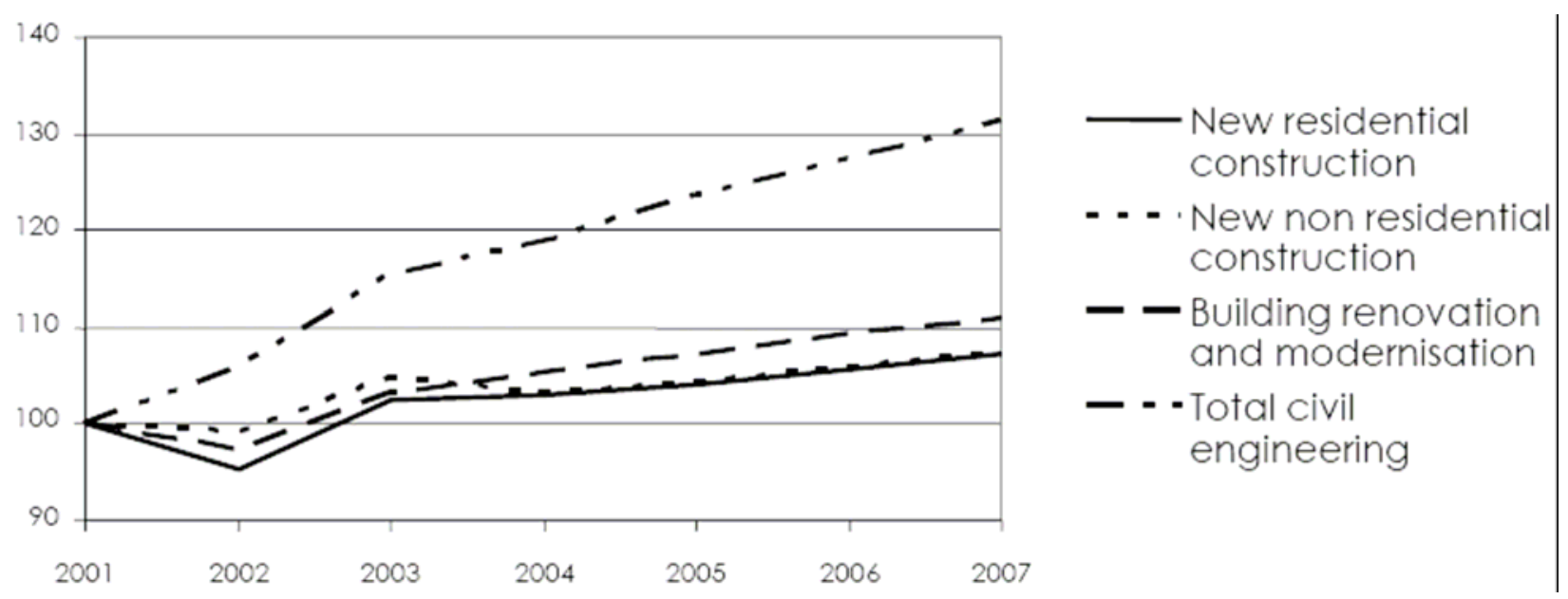

Figura 2 - Evolução dos investimentos na construção civil na Áustria (EUROCONSTRUCT, 2005)

Assim como Portugal, que possui aproximadamente $25 \%$ de seu parque habitacional construído há mais de 60 anos e por volta de $50 \%$ das edificações com idades entre 25 e 60 anos, outros países também demonstram interesse por esse nicho de mercado (LANZINHA; FREITAS; GOMES, 2001). Segundo Appleton (2003), a reabilitação de edifícios vem ganhando cada vez mais importância na Europa, na medida em que os projetistas e construtores identificam o potencial dessa atividade.

\footnotetext{
${ }^{4}$ Conservation du patrimoine architectural de la Ville de Genève, Departement des affaires culturelles, 1999. Disponível em: www.ville-ge.ch/geneve/amenagement/patrimoine/glossaire. Acesso em: 16.12.2007.

${ }^{5}$ Disponível em: http://www.euroconstruct.org/pressinfo/pressinfo.php. Acesso em: 17.11.2007.
} 
Mas o mercado de reabilitação de edifícios tem potencial para atrair mais adeptos no Brasil. Por exemplo, para Ducap, Oriolli e Qualharini (2001), a reabilitação dos sistemas prediais deve ser realizada a cada 25 anos nas edificações. Dessa forma, o estoque existente de edifícações aptas à reabilitação já é considerável e deverá continuar crescendo com a ampliação do parque edificado.

Wiazowski (2007) afirma que está aumentado o interesse de empresas em ocupar edifícios antigos reabilitados. Para viabilizar essa ocupação, segundo o autor, as alternativas mais freqüentes praticadas na cidade de São Paulo, são:

i. a empresa interessada em se instalar em determinada região identifica, adquire o imóvel e contrata empresa especializada para realizar a reabilitação no edifício;

ii. a empresa interessada em se instalar na região identifica o imóvel e lança uma concorrência no mercado nos moldes "built-to-suit", ou seja, a empresa vencedora da concorrência deverá adquirir o imóvel, realizar a reabilitação e alugá-lo à empresa interessada por um período prédeterminado entre as partes; e

iii. um investidor ou grupo de investidores identifica o imóvel, reabilita o edifício de acordo com a exigência do mercado de escritórios comerciais e oferece ao mercado para locação ou venda.

Dentre outros fatores que justificam os processos de reabilitação de edificações já apresentados, destacam-se também:

Aproveitamento da infra-estrutura existente no entorno e da sua localização

Para o vice-presidente do SECOVI, Alberto Du Plessis ${ }^{6}$, "as gerações anteriores construíram os edifícios que as novas irão modernizar, pois está cada vez mais difícil de serem encontrados terrenos na cidade de São Paulo para novas incorporações".

\footnotetext{
${ }^{6}$ Disponível em: http://www.secovi.com.br/noticias/mostra_noticia.php?cont_id=1673\&hist=1. Acesso em 29.set. 07.
} 
Roders (2006) retrata o parque edificado das grandes cidades da Holanda e Portugal como prestes a "arrebentar pelas costuras com demasiados edifícios desocupados".

Os edifícios antigos, principalmente aqueles situados nos grandes centros urbanos, estão inseridos em regiões que receberam investimentos em infra-estrutura ao longo dos anos. Dessa forma, a moradia na área central reduz custos do Estado, pois garante o acesso ao sistema de transporte, malha viária, redes de telefonia e lógica, energia elétrica, água e esgoto; além de equipamentos comunitários como hospitais, postos de saúde, creches, escolas, cinemas, teatros etc., o que dificilmente é garantido nas áreas mais periféricas (PROJETO REABILITA, 2007).

Vaz e Vasconcelos (2003) afirmam que a moradia no centro é a localização ideal, pois, além do acesso aos serviços e equipamentos públicos, reduz a distância dos deslocamentos e estimula a ocupação dos imóveis vazios.

Wiazowski (2007) apresenta os resultados do estudo da reabilitação do edifício São Bartolomeu, localizado ao lado do Edifício Itália, na Avenida Ipiranga, região central da cidade de São Paulo. A construção da década de 1930 foi inteiramente reabilitada para abrigar uma empresa de call center. Segundo o autor, devido à localização do imóvel e à infra-estrutura existente na região, a empresa reduziu em $22 \%$ o custo com folha de pagamento de vale-transporte para os seus 315 funcionários.

\section{* Impacto na paisagem urbana}

Um empreendimento de reabilitação pode gerar impactos no meio em que ele está inserido e, como Arantes (2001) sugere, "quanto maior esse impacto, melhor o poder de repercussão da idéia de reabilitar. Operações com planejamento e execução de forma global tendem a causar impacto mais forte".

Segundo Silva (2004), a reabilitação de um edifício antigo transforma a sua relação com a vizinhança. Além de atrair novos usuários à região, a edificação reabilitada modifica a paisagem urbana e proporciona melhoria da qualidade de vida dos 
habitantes. Além da preservação dos aspectos externos, "propicia a nítida percepção de seu pertencimento a uma ambiência do passado e da história da cidade".

Essa "transformação da relação com a vizinhança", mencionada pela autora, pode ser a porta de entrada para a requalificação urbana de toda região degradada de uma cidade e pode, ainda, contribuir com a sua valorização comercial.

\section{* Preservação do patrimônio histórico e cultural;}

Appleton (2003) defende que a postura dos projetistas em empreendimentos de reabilitação deve prezar pela "compreensão e respeito pelo edifício e seus antecedentes", o que sugere precauções e cuidados especiais para "preservar o patrimônio existente para as próximas gerações".

Segundo Roders (2006), a solução mais freqüente nos projetos negligencia o "passado" (valor histórico) e "futuro" (recursos finitos) das edificações, principalmente daquelas que não estão amparadas por instituições de proteção ao patrimônio histórico e cultural.

Do outro lado, estão os imóveis protegidos por lei contra a sua demolição ou descaracterização arquitetônica. É o caso do empreendimento Park Hèrmes $(\mathrm{PH})$ em Lyon, França que será apresentado no capítulo de estudos de caso${ }^{7}$. Assim como o $\mathrm{PH}$, outras construções são alvo de intervenções de reabilitação e, em determinados casos, com mudança de uso.

Independentemente do imóvel estar listado entre aqueles nos quais os valores histórico e cultural já foram reconhecidos, Roders (2006) destaca a importância de se utilizar um modelo de processo de projeto para empreendimentos de reabilitação que considere e respeite o passado, presente e futuro da edificação. Segundo a autora, antes de qualquer intervenção significativa ser executada na edificação, deve-se procurar identificar e interpretar os valores culturais da edificação, levandose em conta os seguintes aspectos: social, econômico, político, histórico, estético, científico, ecológico e tempo de vida.

\footnotetext{
${ }^{7} 5.3$ - Estudo de Caso 3: Résidence Park Hermès (Lyon, Paris) p.142
} 


\section{Déficit habitacional e a sustentabilidade ambiental}

Segundo dados do levantamento realizado pelo Sindicato da Construção Civil do Estado de São Paulo (Sinduscon-SP) e a Fundação Getúlio Vargas (FGV), atualmente o déficit habitacional brasileiro é de 7,96 milhões de moradias. Sendo que $93 \%$ desse total está concentrado em famílias com renda até cinco salários mínimos (CHOUCAIR, 2007).

Segundo Arantes (2001), uma das possibilidades para solucionar, ainda que parcialmente, o déficit habitacional das grandes cidades é a conversão dos edifícios abandonados, nos centros dessas cidades, em edifícios habitacionais, por meio da reabilitação.

Para Barros e Kowaltowski (2001), o destino dos edifícios obsoletos e desocupados deve ser a sua reabilitação para atender ao mesmo uso ou a outro diferente. A demolição do imóvel deve ser considerada apenas quando a reabilitação não é viável do ponto de vista técnico-econômico. Para Sayegh (2008), o conceito de se projetar um edifício pensando no seu reúso e que permita a sua desmontagem - e não a sua demolição - não está presente na mente dos arquitetos brasileiros.

O processo de demolição de uma edificação implica em desperdício de materiais e energia aplicada na etapa de construção. Roders (2006) defende que em um edifício existem muitas formas, componentes e materiais que poderiam ser reutilizados, reprocessados ou reciclados. Segundo a autora, de uma forma geral, os projetistas estão mais preocupados com suas realizações presentes e menos preocupados com o futuro nos seus projetos, "enquanto o planeta reclama por atenções ecológicas, no que diz respeito ao uso, transformação e desperdício de recursos; especialmente os não renováveis".

Projetos de reabilitação encontram, normalmente, limitações impostas pelo partido arquitetônico da edificação. Um dos grandes desafios para os projetistas é a adequação às exigências legais e às necessidades atuais por sistemas de automação, sistemas prediais e flexibilidade de uso dos ambientes, devido às 
limitações físicas dos edifícios antigos. A decisão de reabilitar um edifício deve ser fruto da análise de estudos de viabilidade técnico-comercial.

Quando o interesse pela reabilitação é para atender à demanda por imóveis comerciais, Wiazowski (2007) alerta que a estrutura existente deve ser amplamente investigada para que seja identificado o seu potencial de adequação aos novos conceitos de edifícios de escritórios.

Segundo Freitas e Souza (2003), quando um edifício apresenta um conjunto significativo de patologias não é possível partir diretamente para a execução das obras sem um estudo de diagnóstico, que será a primeira fase do processo de reabilitação. Os mesmos autores propõem que o diagnóstico seja realizado de forma detalhada e contemple medições e sondagens, em campo, das patologias apresentadas pelo edifício.

As etapas de um empreendimento de reabilitação não são idênticas às de um empreendimento tradicional ou "novo", a começar por aquelas de diagnóstico e estudo de viabilidade técnico-comercial.

$\mathrm{Na}$ etapa de projetos, a edificação existente é um elemento que deve ser considerado. Na etapa de execução das obras, por exemplo, a falta de padronização das medidas da edificação existente pode interferir na execução dos serviços e, por conseqüência, na produtividade da obra. A complexidade dos empreendimentos de reabilitação, embora possa variar de acordo com o grau de interferência que se pretende na edificação, exige uma gestão adequada.

Dessa forma, embora existam diversas razões para que o mercado de reabilitação de edifícios no Brasil seja ainda maior, alguns aspectos precisam ser melhor equacionados, principalmente no que diz respeito à interface entre a elaboração dos projetos e à execução das obras, visando maior eficácia e eficiência do processo de reabilitação de edifícios. 


\subsection{OBJETIVOS}

O objetivo do presente trabalho é descrever e analisar a gestão do processo de projeto em empreendimentos de reabilitação de edifícios, identificando suas características particulares e seus principais entraves, especialmente aqueles que ocorrem na interface entre a fase de projeto e de execução das obras.

Para possibilitar essa análise, faz-se necessária a caracterização dos empreendimentos dessa natureza, quanto às demandas específicas relacionadas à gestão de projetos e à execução de obras de reabilitação.

Além disso, serão apresentadas proposições de diretrizes mais apropriadas para a gestão de projetos em empreendimentos de reabilitação, as quais serão fruto da identificação das limitações das práticas convencionais nesses empreendimentos.

\subsection{METODOLOGIA}

A Metodologia deste trabalho foi dividida em três etapas que serão descritas a seguir: pesquisa bibliográfica, estudos de caso e análise crítica dos estudos de caso.

A primeira parte do trabalho consiste no levantamento bibliográfico sobre o tema. Buscou-se, nessa etapa, levantar as principais fontes bibliográficas que tratam de assuntos que envolvem a gestão do processo de projeto e a reabilitação de edifícios.

$\mathrm{Na}$ etapa de estudos de caso foram coletados dados que visam ilustrar parte das pesquisas realizadas na etapa de revisão bibliográfica. Além disso, a análise dos dados coletados contribuiu com a discussão sobre a necessidade de mudança de cultura para a gestão de projetos de reabilitação de edifícios. 
A escolha dos estudos de caso teve como premissa a relevância dos empreendimentos no contexto da reabilitação de edifícios, e a disponibilidade e o acesso às informações relativas à gestão de projetos e à execução das obras.

No capítulo que trata da compilação dos dados e análise crítica dos resultados dos estudos de caso, serão apresentados três empreendimentos com características de reabilitação distintas do ponto de vista de motivação para reabilitação, organização do empreendimento e abordagem da gestão do processo de projeto.

O primeiro estudo de caso que será apresentado, refere-se a uma iniciativa do poder público de reabilitar um edifício residencial, localizado na região central da cidade de São Paulo. Foram realizadas visitas ao escritório da empresa construtora no canteiro e ao escritório central da empresa incorporadora, onde foram analisados os documentos, incluindo projetos e documentos técnicos. No canteiro de obras, as visitas foram realizadas na primeira metade do andamento das obras e após a sua conclusão. Foram entrevistados: a responsável pelo programa de reabilitação da empresa incorporadora; a arquiteta responsável pelo gerenciamento das obras por parte da incorporadora; o engenheiro responsável pelo gerenciamento das obras por parte da empresa gerenciadora; o engenheiro residente responsável pela execução das obras (representante da construtora); e usuários do edifício reabilitado.

O segundo estudo de caso refere-se a uma iniciativa do setor privado. Trata-se da reabilitação de um conjunto de quatro edifícios localizados no bairro paulistano da Moóca (região central). Nesse estudo de caso foram realizadas visitas ao canteiro de obras e ao escritório da empresa incorporadora, onde foram analisados os documentos, incluindo projetos e documentos técnicos. As visitas ao canteiro de obras foram realizadas na primeira metade do andamento das obras e quando próximo à sua conclusão. Foram entrevistados, no escritório da empresa incorporadora/ construtora, a gerente de projetos e o diretor técnico e, no canteiro, o mestre de obras, a coordenadora de projetos e o estagiário de engenharia. 
O terceiro e último estudo de caso foi realizado na cidade de Lyon, França ${ }^{8}$. O edifício, reabilitado por empresa privada, foi visitado na segunda metade do andamento das obras, onde foram analisados os documentos técnicos e realizadas as entrevistas. Essas entrevistas foram feitas com o engenheiro responsável pela obra por parte da incorporadora e com o engenheiro responsável pelos sistemas prediais da empresa instaladora subcontratada. Além disso, foram feitas consultas complementares, por e-mail e pesquisas, sobre o empreendimento na internet. $\mathrm{O}$ material coletado foi utilizado na compilação dos dados desse estudo de caso.

As entrevistas e visitas aos empreendimentos foram guiadas pelo documento apresentado no ANEXO A - Roteiro para entrevistas e visitas técnicas.

A análise crítica dos resultados é fruto da confrontação das informações coletadas nas etapas de pesquisas bibliográficas e estudos de caso. A análise dos estudos de caso, em particular, permitiu a identificação de vantagens e problemas na gestão do processo de projeto dos empreendimentos de reabilitação, bem como a identificação de aspectos que precisam ser melhor estudados e implementados nesse tipo de empreendimento.

A experiência profissional do autor adquirida no Instituto de Pesquisas Tecnológicas do Estado de São Paulo (IPT), na área de diagnóstico para reabilitação e estudo de patologias de edificações; na Companhia de Desenvolvimento Habitacional e Urbano do Estado de São Paulo (CDHU) na área de gerenciamento de obras e interface com áreas de projetos; e na Dectra Engenharia (empresa de construção civil paulistana), na execução de obras de reabilitação comerciais e residenciais, também contribui com as análises críticas presentes no trabalho.

\subsection{ESTRUTURA DO TRABALHO}

\footnotetext{
${ }^{8} \mathrm{O}$ estudo de caso Park Hèrmes deu origem à publicação do artigo: "Etapa de diagnóstico de um projeto de reabilitação: estudo de um caso francês" de autoria de CROITOR, OLIVEIRA e MELHADO (2007) publicado no VII Workshop Brasileiro de Gestão no Processo de Projeto na Construção de Edifícios, Curitiba, 2007.
} 
A estrutura do trabalho reflete a seqüência da pesquisa realizada e procura promover a integração entre as pesquisas teórica e de campo, com uma análise crítica final das informações coletadas durante todo o processo de pesquisa.

Além do primeiro capítulo, que apresenta a problemática da pesquisa, a contextualização do tema, objetivos, metodologia adotada e a estruturação do trabalho, foram desenvolvidos outros quatro capítulos e, também, as considerações finais. A pesquisa bibliográfica é apresentada nos capítulos primeiro ao quarto. No capítulo cinco são apresentados os resultados das pesquisas de campo e o capítulo sexto contempla as considerações finais.

No segundo capítulo será apresentada a caracterização do processo de reabilitação de edifícios. A conceituação da terminologia adotada no trabalho, as principais características de empreendimentos de reabilitação, bem como as suas diferenças em relação aos empreendimentos convencionais sob o ponto de vista da gestão de projetos, são assuntos apresentados nessa etapa. Além dessa abordagem, será discutida a amplitude desse mercado e os principais campos de aplicação.

No terceiro capítulo será discutida a gestão do processo de projetos de empreendimentos de reabilitação e a interface do projeto com a execução das obras. Além disso, serão discutidas propostas de processos de reabilitação que contemplam as etapas de diagnóstico e desenvolvimento dos projetos e execução das obras.

No quarto capítulo será abordada a importância da coordenação de projetos nos empreendimentos de reabilitação de edifícios. Serão apresentadas as principais atividades do coordenador de projetos, bem como uma discussão sobre o perfil apropriado para esse profissional e sobre os modelos de coordenação existentes e adequados para esses projetos.

No capítulo cinco serão apresentados os resultados dos três estudos de caso realizados. Essa etapa do trabalho contempla os resultados da pesquisa de campo realizada em dois empreendimentos de reabilitação situados na região central da 
cidade de São Paulo e um empreendimento situado na cidade de Lyon, França. Os casos nacionais apresentam dois modelos diferentes de gestão de projetos para empreendimentos de reabilitação. Finalmente, o estudo de caso realizado em Lyon, França, apresentará um terceiro modelo de gestão de projetos aplicado a um empreendimento, no qual o desempenho técnico da edificação foi o fator principal.

No capítulo seis será apresentada a compilação dos principais comentários pertinentes aos entraves identificados na gestão de projetos de reabilitação. Além das principais características desses empreendimentos que os distinguem dos "novos" ou convencionais, serão apresentados os principais aspectos da interface entre projeto e obra. 


\section{CARACTERÍSTICAS DOS PROCESSOS DE REABILITAÇÃO}

O presente capítulo trata da caracterização do processo de reabilitação de edifícios. Aqui será apresentada a conceituação da terminologia adotada no trabalho, as principais características de empreendimentos de reabilitação, bem como as suas diferenças em relação aos empreendimentos convencionais sob o ponto de vista da gestão de projetos. Além dessa abordagem, será discutida a amplitude desse mercado e os principais campos de aplicação.

\subsection{REABILITAÇÃO DE EDIFICAÇÕES: CONCEITUAÇÃO}

Dentre os principais termos-chave que se referem ao tema desenvolvido neste trabalho, destacam-se: reforma, restauro, recuperação, retrofit e reabilitação. Os três primeiros, de uso comum no vocabulário corrente, possuem significados já consagrados e de fácil identificação.

Michaelis ${ }^{9}$, Luft (1987), Ferreira (1977) e Australia ICOMOS (1999) ${ }^{10}$ definem o termo "reformar" como "ato de dar nova forma, mudança para melhor, formar novamente, reconstruir, reorganizar". Já o termo "recuperar" é definido como sendo o ato de "recobrar, tornar a adquirir, reabilitar-se, restabelecer".

Ainda, a palavra "restaurar", segundo os mesmos autores, significa "consertar, reparar, tornar a pôr em vigor, restabelecer, repor em bom estado, renovar". Australia ICOMOS (1999) ${ }^{11}$ define o termo restauração como o ato de devolver ao corpo construído suas características originais, seja removendo componentes ou recompondo-os sem a introdução de novos materiais. O termo restauração deve ser

\footnotetext{
${ }^{9}$ Moderno Dicionário da Língua Portuguesa, disponível em: http://michaelis.uol.com.brl. Acesso em: 15.11.2007.

${ }^{10}$ Disponível em: http://www.icomos.org/australia/burra.html. Acesso em: 16.11.2007.

11 Idem.
} 
entendido como uma intervenção a um patrimônio que visa preservar os seus valores estéticos e históricos originais ${ }^{12}$.

Outro termo encontrado na literatura, principalmente quando a intervenção está relacionada à modernização dos sistemas prediais, é o termo retrofit. Segundo Barrientos (2004), retrofit é a conjunção dos termos "retro", oriundo do latim, que significa movimentar-se para trás e de fit, do inglês, que significa adaptação, ajuste. O termo foi incorporado no vocabulário da indústria aeronáutica nos Estados Unidos e Europa no final da década de 90 e referia-se à modernização dos equipamentos de aeronaves. Da mesma forma, na Construção Civil o termo tem sua aplicação mais recorrente quando o foco principal é a modernização de sistemas de condicionamento de ar, instalações elétricas, de lógica e dados etc.

Já o termo reabilitação, que às vezes é confundido com o termo "renovação" (esse normalmente utilizado para designar operações em áreas urbanas), pode ser entendido como a intervenção em uma determinada construção para recobrar seu estado original, associada a uma modernização da sua infra-estrutura $(\text { CONSERVATION...,1999) })^{13}$.

Segundo a definição de Barrientos e Qualharini (2002), reabilitação é reforma gerenciada de uma construção visando a sua adaptação às novas necessidades dos usuários ou a otimização das atividades desempenhadas por ela com o objetivo de prolongar a vida útil da edificação, proporcionar a modernização de suas funcionalidades e promover a possibilidade de redução do custo de utilização, através da implantação das tecnologias disponíveis.

O Projeto Reabilita (2007) define o termo reabilitação como sendo "o processo pelo qual o imóvel ou o bem urbanístico pode ser recuperado de maneira a contribuir não só para os moradores e proprietários do imóvel, como também em uma escala mais ampla, como um processo a interferir em toda uma área urbana".

\footnotetext{
${ }^{12}$ Conservation du patrimoine architectural de la Ville de Genève, Departement des affaires culturelles, 1999. Disponível em: www.ville-ge.ch/geneve/amenagement/patrimoine/glossaire. Acesso em: 16.12.2007.

${ }^{13}$ Idem.
} 
Appleton (2003) define o termo reabilitação com enfoque no desempenho da edificação. Segundo o autor, a reabilitação deve se propor a melhorar o desempenho local ou geral da edificação, sendo "portanto o conjunto de operações destinadas a aumentar os níveis de qualidade do edifício, de maneira a atingir a conformidade com níveis funcionais de exigência mais severos do que aqueles para os quais o edifício foi concebido."

Pela sua abrangência e alinhamento adequado com o tema, será adotado o termo reabilitação neste trabalho.

\subsection{CAMPO DE APLICAÇÃO DA REABILITAÇÃO DE EDIFICAÇÕES}

No parque edificado das cidades, principalmente das mais antigas, encontram-se empreendimentos passíveis de um processo de reabilitação. Como será apresentado a seguir, as motivações para a reabilitação de uma edificação são diversas e, portanto, não se incluem nesse grupo apenas os edifícios antigos e degradados.

O campo de aplicação de empreendimentos de reabilitação fomenta a atividade industrial ligada à construção civil e ao setor de projetos e serviços. Os principais agentes interessados na reabilitação estão apresentados na figura 3: 


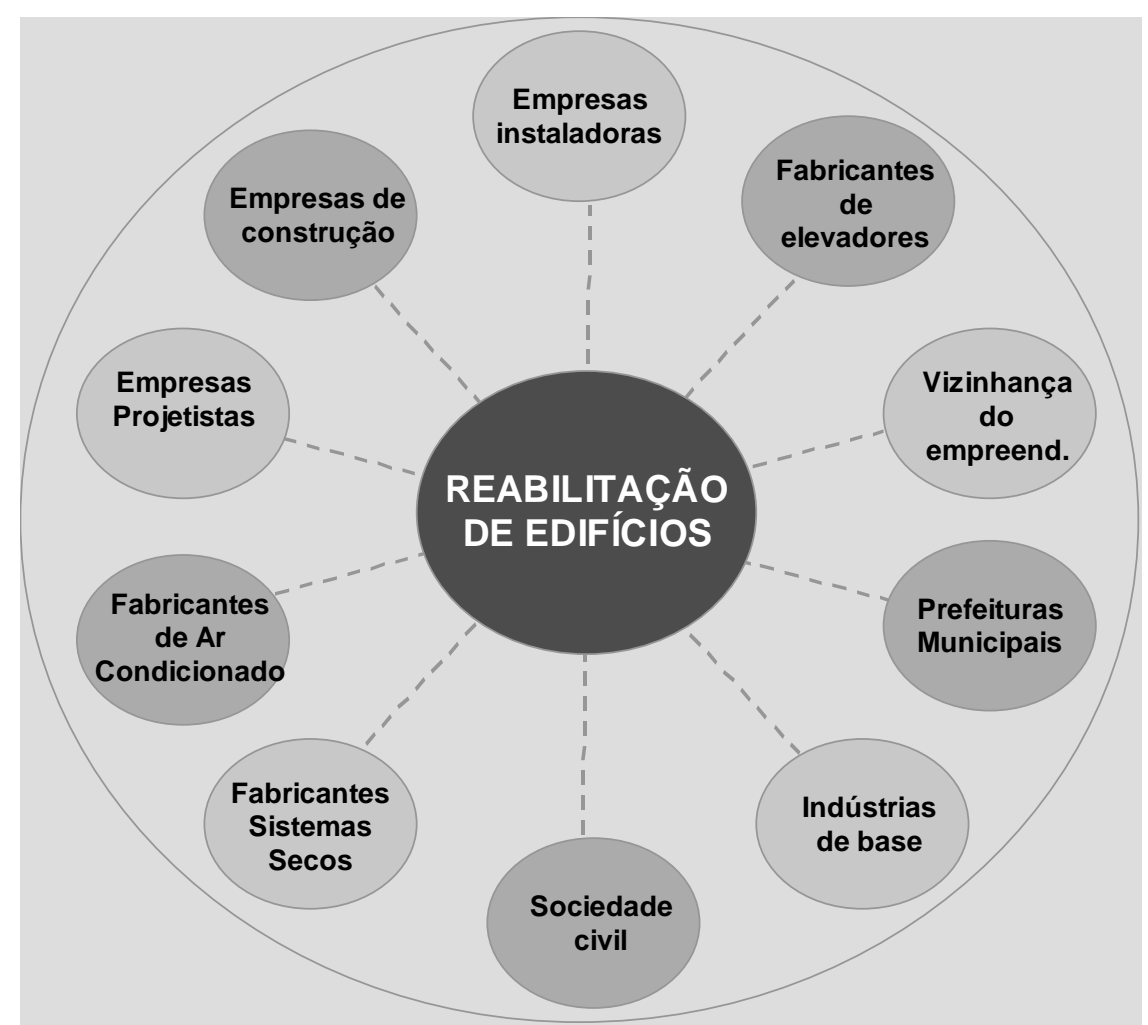

Figura 3 - Agentes envolvidos no processo de reabilitação de edificações (adaptado de MANSO, 2006)

Dentre eles, destaca-se o poder público. Edificações degradadas contribuem para a degradação do seu entorno. Edificações abandonadas eventualmente são alvo de invasões e ocupações irregulares, principalmente no centro das grandes cidades. Nesses casos, a vizinhança é obrigada a conviver com situações de insegurança, ora por aspectos técnicos da edificação (risco eminente de incêndio, por exemplo), ora por aspectos sociais (edificações abandonadas podem servir de abrigo para a marginalidade local).

Segundo Vaz e Vasconcelos (2003), na cidade do Rio de Janeiro, os projetos de intervenção urbana procuravam, no passado, retirar a habitação dos centros das grandes cidades brasileiras. Hoje, existe contraste entre a falta de moradias e o acelerado processo de degradação de edificações desocupadas. As autoras complementam: "somente a habitação garante a atividade e presença de pessoas 24 horas por dia, ou seja, a habitação passou a ser vista como um recurso de recuperação da vitalidade perdida."

Bomfim (2004) constata que os proprietários de espaços edificados vazios, localizados nos centros urbanos, aguardam uma definição de políticas públicas que 
diminuam o risco do investimento na reabilitação dos edifícios. Assim, os proprietários mantêm os imóveis vazios e tentam protegê-los da ocupação por movimentos populares que lutam pelo direito à moradia. Estas ocupações, que ocorrem desde 1980 e evidenciam o problema da falta de habitação para a população de baixa renda, são mecanismos de pressão dos movimentos populares ao poder público.

Essa nova realidade da ocupação dos edifícios, somada ao processo natural de degradação das edificações, aponta para uma nova oportunidade para a indústria da construção civil: a indústria da reabilitação de edificações. Esse nicho de mercado tem sido percebido por empresas projetistas, consultores, incorporadores, construtores etc. como uma oportunidade crescente de negócios com demanda de atividades.

Dessa forma, quatro são os grupos de edificações que potencialmente podem integrar o mercado de reabilitações: edificações antigas e degradadas; edificações inacabadas e abandonadas; edificações com sistemas prediais ineficientes; e edificações cujo uso será modificado.

\subsubsection{Edificações antigas e degradadas}

A atuação do poder público na expansão urbana da cidade, em especial na cidade de São Paulo, com a execução de obras de infra-estrutura em outras regiões nãocentrais, permitiu o deslocamento das atividades produtivas para os bairros. Conseqüentemente, provocou-se o deslocamento de geração, produção e circulação de renda para fora do centro, desencadeando a desvalorização e a desocupação de antigas áreas consolidadas (BOMFIM, 2004).

O processo de desocupação dos imóveis colabora, em parte, com o processo de degradação das edificações, principalmente quando a manutenção da edificação é insuficiente. Appleton (2003) afirma que de uma forma geral os edifícios europeus 
antigos não são submetidos periodicamente a operações de manutenção ${ }^{14}$. Além disso, o autor afirma que há evidências de que em grande parte do parque edificado a manutenção seja insuficiente.

A manutenção nas edificações com a periodicidade e técnica adequadas passa pela questão sócio-cultural. Os edifícios, de uma forma geral, quando são administrados e/ou operados por empresas especializadas e que possuem uma visão não apenas burocrática, mas também e principalmente com foco na manutenção preventiva, estabelecem procedimentos e rotinas que retardam o processo de degradação natural das edificações.

Entretanto, segundo Roders (2006), o usuário pode realizar a manutenção adequada na edificação, mas, invariavelmente, ele contribui com a sua efetiva degradação. Além disso, independentemente da ação humana, o processo de deterioração pode ser retardado, mas não interrompido. "Assim como os seus usuários envelhecem", as edificações naturalmente estão em constante processo de degradação.

Appleton (2003) ressalta que a degradação dos edifícios se dá pela ação de agentes climáticos e pelo uso da edificação. Estes fatores contribuem para o envelhecimento dos materiais aplicados, alterando algumas propriedades fundamentais como, por exemplo, as características de elasticidade, resistência mecânica etc.

O(s) proprietário(s) do edifício muitas vezes não tem condição de avaliar, ao longo do tempo, o impacto direto do investimento de uma manutenção adequada, ou não, no valor venal do imóvel. Imóveis residenciais, por exemplo, constantemente são alvo do descaso quando o assunto é manutenção predial, como ilustra a Figura 4. As taxas de condomínio nem sempre contemplam custos com manutenção preventiva e/ou corretiva. Aos poucos, a edificação vai incorporando o estado de degradação a ponto de influenciar na sua valorização comercial.

\footnotetext{
${ }^{14}$ Aplleton (2003) define o termo manutenção como sendo "o conjunto de operações preventivas destinadas a manter, em bom funcionamento, a edificação e as suas partes constituintes, incluindo limpezas e pinturas, inspeções e pequenas reparações."
} 


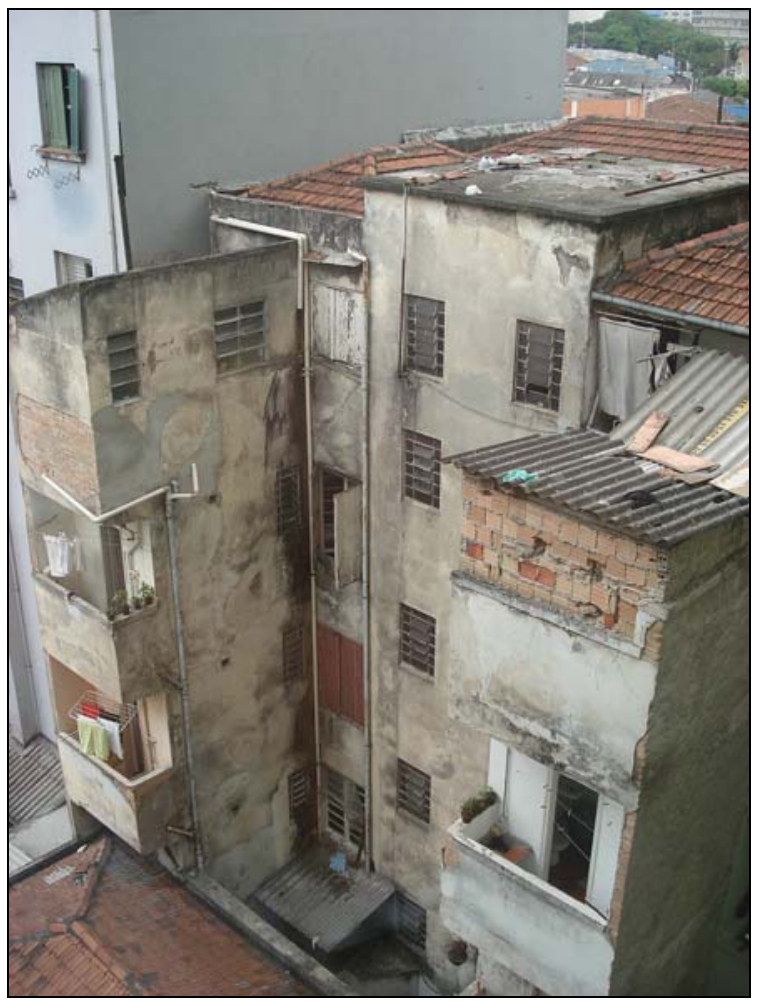

Figura 4 - Edificação localizada no centro de São Paulo, com sinais evidentes de degradação (arquivo do autor)

As edificações comerciais, por sua vez, sofrem de situação semelhante. Estudo realizado pela Cushman \& Wakefield Semco (2005) ${ }^{15}$ apresenta dados que indicam que ainda que a manutenção seja efetiva, com o passar do tempo o processo de degradação da edificação provoca a desvalorização do imóvel. Apenas uma reabilitação estruturada é capaz de recobrar a tendência de valorização de mercado do imóvel.

A Figura 5 representa o comportamento do valor de mercado de uma edificação comercial padrão. Ao analisar este gráfico, pode-se perceber que até mesmo uma manutenção eficiente não recobra a tendência dos índices de valor de mercado de um imóvel novo. Entretanto, a reabilitação é capaz de retomar gradualmente a valorização do imóvel, ainda que em um tempo mais longo. O principal aspecto da reabilitação bem sucedida, principalmente de edifícios das áreas centrais, é a

\footnotetext{
${ }^{15}$ Documento não publicado, apresentado por Telma Fattori Nunes da empresa Cushman \& Wakefield Semco em um evento organizado pelo SECOVI em 28.out.05, fornecido ao autor deste trabalho.
} 
redução do custo de operação que a modernização possibilita somada à localização e infra-estrutura consolidada dos arredores.

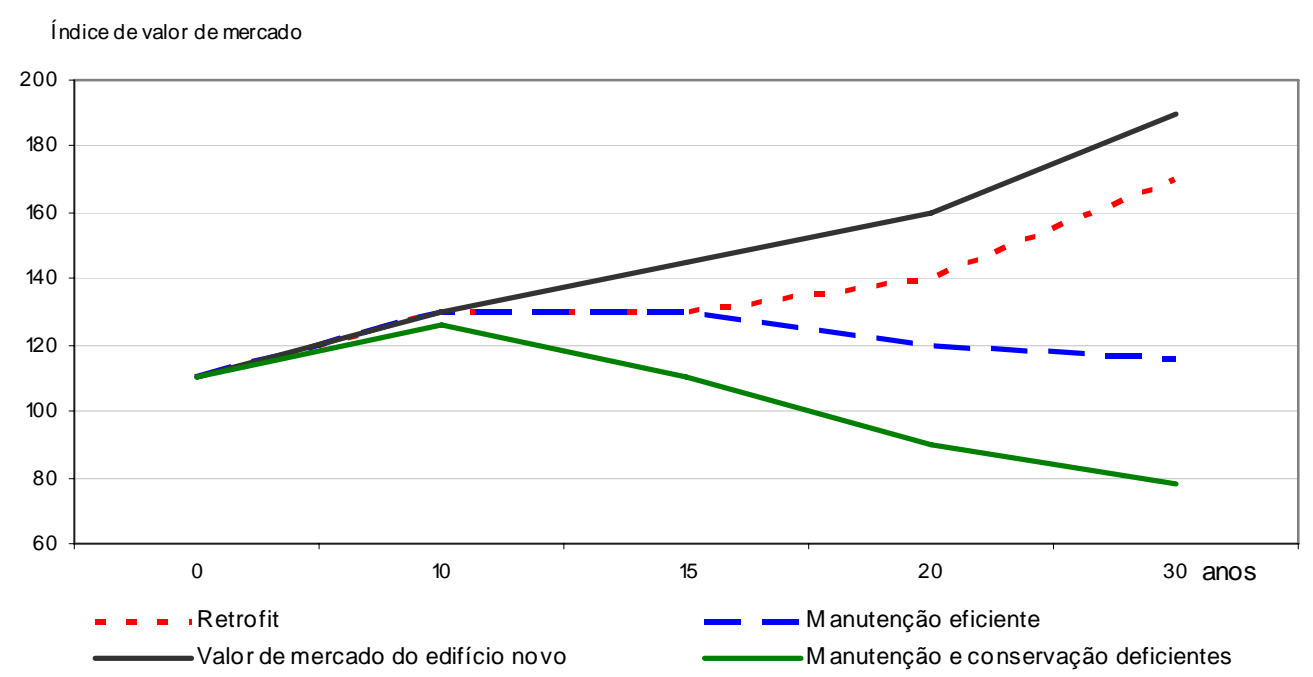

Figura 5 - Desempenho de um edifício comercial (adaptado de CUSHMAN \& WAKEFIELD SEMCO, 2005)

O processo de expansão territorial descrito por Bomfim (2004), na cidade de São Paulo, foi apoiado na instalação de infra-estrutura urbana em novas áreas, no investimento de capital público e privado e com o deslocamento dos órgãos públicos para fora da região central da cidade. Neste contexto, o centro histórico deixou de ser a principal área de atração da cidade e, por conseqüência, perdeu parte da demanda por imóveis.

Neste processo, houve a migração das empresas para outras áreas, tais como: Paulista, Marginal Pinheiros, Faria Lima, Itaim e Verbo Divino, onde a criação de novos espaços com novas estruturas e novas tecnologias atraiu as empresas (BOMFIM, 2004).

Cushman \& Wakefield Semco (2005), ilustra a dinâmica do mercado imobiliário na figura 6. Nota-se que, até a década de 1960, a construção de imóveis comerciais de escritórios concentrava-se na região central da cidade. Na década seguinte, o alvo foi deslocado para a região da Avenida Paulista. Na década de 1980, o movimento maior de construção de imóveis comerciais voltou-se para a região da Avenida Faria Lima. Na década de 1990, o bairro Itaim Bibi recebeu os maiores investimentos 
dessa natureza, seguido, posteriormente, pela região da Marginal. No estudo dessas regiões foram identificados 1.213 edifícios de escritórios comerciais construídos entre os anos de 1960 e 1995.

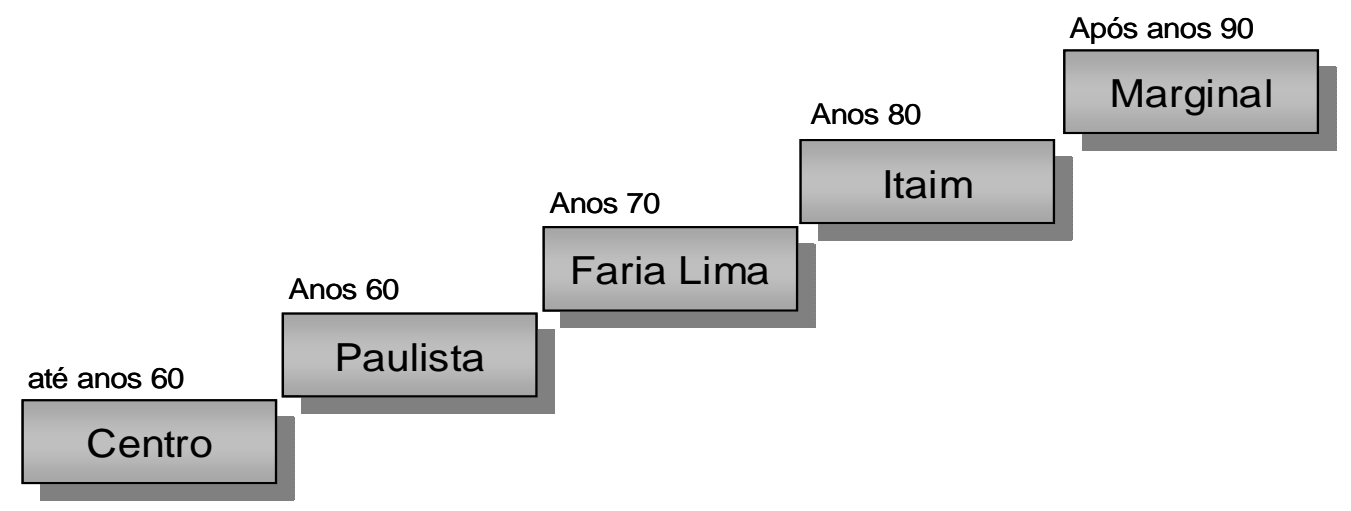

Figura 6 - Migração dos investimentos no mercado de edifícios comerciais de escritórios da cidade de São Paulo, SP (adaptado de CUSHMAN \& WAKEFIELD SEMCO, 2005)

Esse estoque de edifícios, quando extrapolado para as demais cidades do país, representa um volume significativo de edificações com mais de dez anos de construção que, de alguma forma, deveriam passar por um processo de reabilitação nos próximos anos.

As motivações para a reabilitação de edificações degradadas podem ser diversas:

- necessidade de adequação da edificação às normas e legislações atuais;

- necessidade de se flexibilizar o layout dos andares para tornar o imóvel mais atraente comercialmente;

- intenção de se reduzir o custo de operação e manutenção dos edifícios;

- necessidade de adequação das instalações para uma nova demanda de energia do edifício;

- necessidade de serem realizados serviços de recuperação estrutural e/ou de fachadas;

- necessidade de adaptação do imóvel para acessibilidade universal;

- interesse na adaptação das áreas comuns às demandas contemporâneas;

- necessidade de recuperação dos sistemas de impermeabilização; e

- $\quad$ interesse na revalorização de preço de mercado do imóvel etc. 


\subsubsection{Edificações inacabadas e abandonadas}

Além dos empreendimentos degradados pela falta de manutenção e/ou má utilização das edificações e instalações, as edificações inacabadas e abandonadas por longo período também se tornam alvo de empreendimentos de reabilitação (Figura 7).

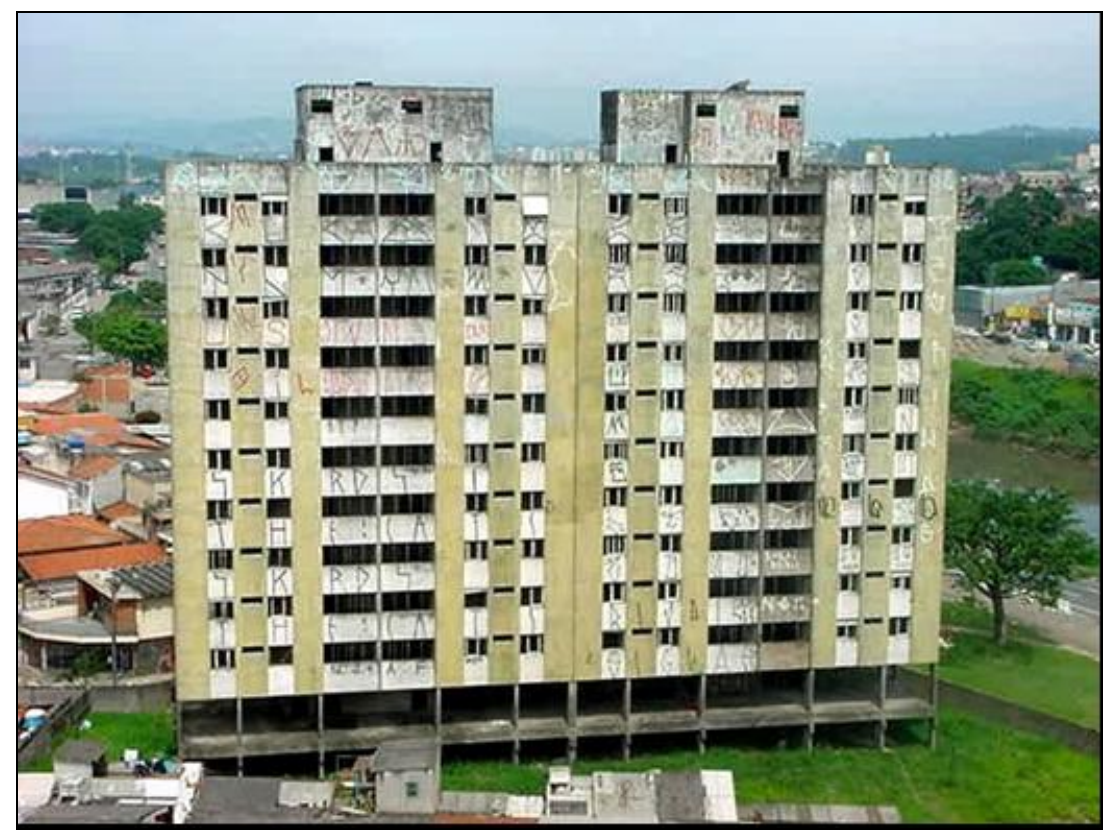

Figura 7 - Condomínio residencial localizado na cidade de Osasco - SP: obra inacabada e abandonada (arquivo do autor)

Embora os edifícios inacabados e abandonados não tenham sido oficialmente habilitados e, portanto, não se deva utilizar o termo "reabilitação", na prática percebe-se que as intervenções têm a mesma natureza daquelas realizadas nos empreendimentos de reabilitação. Além disso, pode-se atribuir o estado de abandono da edificação como sendo a sua "habilitação" parcial, incompleta e/ou imprópria.

As razões pelas quais os empreendimentos são abandonados antes do término das obras podem ser: falta de recursos do investidor para a conclusão das obras, mudança da política de investimento do investidor, falência da empresa 
incorporadora, interdição judicial das obras, problemas técnicos de execução que demandam alto investimento para correção etc.

As soluções técnicas para a reabilitação podem envolver um alto volume de recursos, dependendo do estado de degradação e, muitas vezes, a edificação é destinada ao abandono. Quando o projeto permite flexibilidade para mudança de uso ou adaptação aos padrões modernos de projeto, ou quando a localização é valorizada, o projeto pode atrair investimentos externos que viabilizem sua reabilitação.

Diversos empreendimentos inacabados podem ser encontrados, ainda hoje, pelas principais cidades do país. Não são apenas os empreendimentos públicos que são lançados ao abandono. Infelizmente, empreendimentos privados também são alvo dessa prática que desencadeia o processo de degradação da edificação e do entorno.

O caso mais conhecido no meio privado foi o legado deixado pela empresa construtora e incorporadora Encol. Após o encerramento de suas atividades, diversos empreendimentos inacabados foram abandonados e se tornaram objetos de litígios entre a empresa, fornecedores e mutuários.

Esses empreendimentos, que entraram em processo de degradação devido ao abandono, foram, aos poucos, sendo retomados pelos mutuários, com autorização judicial. Devido ao desequilíbrio entre o investimento por eles já desembolsado para a Encol e os recursos efetivamente aplicados ao canteiro de obras, diversas associações de mutuários encontraram dificuldades financeiras para retomar as obras e atender aos padrões projetados inicialmente.

Além dos imóveis da empresa citada, diversas outras edificações abandonadas e inacabadas são potenciais alvos de empreendimentos de reabilitação. Nesses casos, quando há um grupo de proprietários de uma mesma edificação, o processo de reabilitação possui peculiaridades tanto na modelagem do negócio em si, quanto nas etapas de desenvolvimento dos projetos e execução das obras. 


\subsubsection{Edificações com sistemas prediais ineficientes ou inadequados}

Além dos casos de reabilitação de edificações cujo processo de degradação está acelerado, as intervenções de reabilitação podem ter o foco principal voltado para a atualização dos sistemas prediais ou a sua readequação a uma nova necessidade.

Segundo Wiazowski (2007), as empresas têm buscado nos imóveis comerciais espaços que favoreçam o melhor desempenho de seus funcionários e, ao mesmo tempo, contribuam para uma redução de custos, no que diz respeito à operação e manutenção dos edifícios.

Quando o interesse principal é a modernização dos sistemas prediais, tem-se o chamado retrofit da edificação. Ele ocorre principalmente em edificações comerciais e, normalmente, visa, além da adequação dos espaços, o aumento da eficiência dos sistemas prediais através da substituição das instalações existentes por sistemas mais modernos, como ilustra a Figura 8.

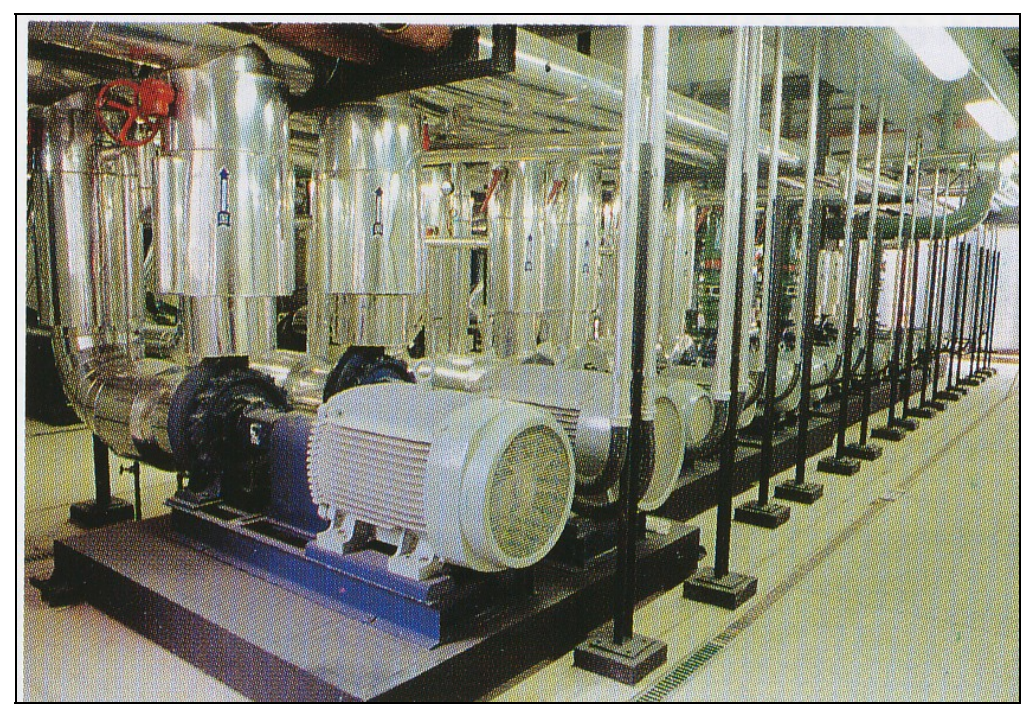

Figura 8 - Nova central de ar condicionado com termoacumulação da Bolsa de Mercadoria e Futuros, no centro da cidade de São Paulo (Revista Téchne n46)

Os sistemas de ar condicionado antigos, por exemplo, costumam ser mais ineficientes que os novos sistemas. As instalações elétricas das edificações antigas 
muitas vezes não atendem à demanda atual e o sistema trabalha constantemente sobrecarregado. As instalações hidro-sanitárias antigas consomem recursos em níveis acima do necessário (bacias sanitárias, por exemplo), normalmente não há sistemas de reutilização de água para lavagem de áreas comuns etc.

Analisando-se a metodologia de classificação de escritórios comerciais, proposta pelo Núcleo de Real State da Escola Politécnica da Universidade de São Paulo (NRE/POLI/USP), nota-se que a reabilitação de edifícios pode contribuir para melhorar a classificação de um imóvel e, por conseqüência, aumentar a sua valorização comercial. A maior parte dos grupos de atributos analisados neste sistema de classificação refere-se aos sistemas prediais, como apresentado na Tabela 1.

Tabela 1 - Principais grupos de atributos para classificação de imóveis comerciais de NRE/POLI/USP (adaptado de WIAZOWSKI, 2007)

$1^{0}$ Sistema de supervisão e controle predial

(integração do monitoramento dos sistemas prediais)

$2^{\circ}$ Sistema de ar condicionado central

(zonas de VAV, termostatos nos andares, chillers etc.)

$3^{\circ}$ Sistema de telecomunicação e informática

(shafts dedicados, fibra ótica etc.)

$4^{\circ}$ Sistema de detecção e combate a incêndio

(sprinkler, detector de fumaça, iluminação emergência etc.)

$5^{\circ}$ Sistema de energia elétrica

(capacidade de atendimento, sob piso elevado etc.)

$6^{\circ}$ Sistema de iluminação

(iluminação natural, ilum. artificial divida por setores etc.)

$7^{\circ}$ Sistema hidráulico

(reservatórios, prumadas adicionais etc.) $8^{\circ}$ Segurança patrimonial (controle acesso pedestres e automóveis, CFTV etc.)

$9^{\circ}$ Elevadores

(tempo de resposta mín., elevador serviço separado etc.)

$10^{\circ}$ Estacionamento

(01 vg para cd $30 \mathrm{~m}^{2}$, vg independente $\mathrm{p} /$ visitantes etc.)

$11^{\circ}$ Eficiência do projeto

(flexibilidade de leiaute, existência de shafts etc.)

$12^{\circ}$ Lobby

(espaço, pé-direito duplo etc.)

$13^{\circ}$ Fachada

(isolamento termo-acústico etc.)

$14^{\circ}$ Localização

(infra-estrutura, segurança e acesso)

Empresas especializadas em consultoria imobiliária têm se dedicado a desenvolver estudos de viabilidade técnico-econômica de reabilitação para edifícios que possam 
abrigar suas empresas-cliente. Aproveitam esse nicho de mercado para oferecer imóveis com localização estratégica e infra-estrutura na vizinhança já instalada e consolidada.

Projetos de reabilitação são mais facilmente aplicados a edificações comerciais e ocupadas por uma única empresa ou que pertença a único proprietário. Nessas situações, os processos tendem a ser mais ágeis e objetivos (OCUPANTES..., 2006 apud WIAZOWSKI, 2007).

Segundo Cushman \& Wakefield Semco (2005), que apresenta um levantamento de imóveis comerciais com potencial de intervenção em nove regiões na cidade de São Paulo (Centro, Paulista, Jardins, Faria Lima, Itaim, Vila Olímpia, Berrini, Chácara Santo Antônio e Marginal), 62,25\% possuíam algum tipo de sistema de condicionamento de ar.

A análise de Cushman \& Wakefield Semco (2005) restringiu o estudo às edificações construídas no período de 1960 a 1995 que possuíssem sistema de condicionamento de ar, por ser requisito essencial em imóveis comerciais contemporâneos. A amostragem foi então reduzida para 216 edifícios. Devido à facilidade operacional de intervenção e posterior locação do edifício, o estudo priorizou os imóveis que possuíssem um único proprietário ou ocupante. Esse número caiu para 87 edifícios, perfazendo um total de aproximadamente $700.000 \mathrm{~m}^{2}$ de área construída. O estudo concluiu que há um mercado em crescimento para os empreendimentos de reabilitação de imóveis comerciais e que há uma boa parcela dessa oferta com perfil apropriado para esse tipo de intervenção.

Cushman \& Wakefield Semco (2005) apresentou também o resultado de uma simulação de estudo de viabilidade técnica-econômica de uma dessas edificações com alto potencial de intervenção (Figura 9). Para isso, contou com a colaboração de fabricantes de sistemas e materiais e projetistas das diversas disciplinas envolvidas no empreendimento. O imóvel estudado foi o Edifício Wilson Mendes Caldeira, localizado no Brooklin Novo (região Marginal). O edifício comercial, projetado em 1978 por Adolpho Lindemberg, possui 14 andares e área do andar-tipo 
de $940 m^{2}$. A estimativa de custo da reabilitação da edificação foi da ordem de $R \$ 6$ milhões, o que representa $\mathrm{R} \$ 382,17$ / m² com pay back em 22 meses.

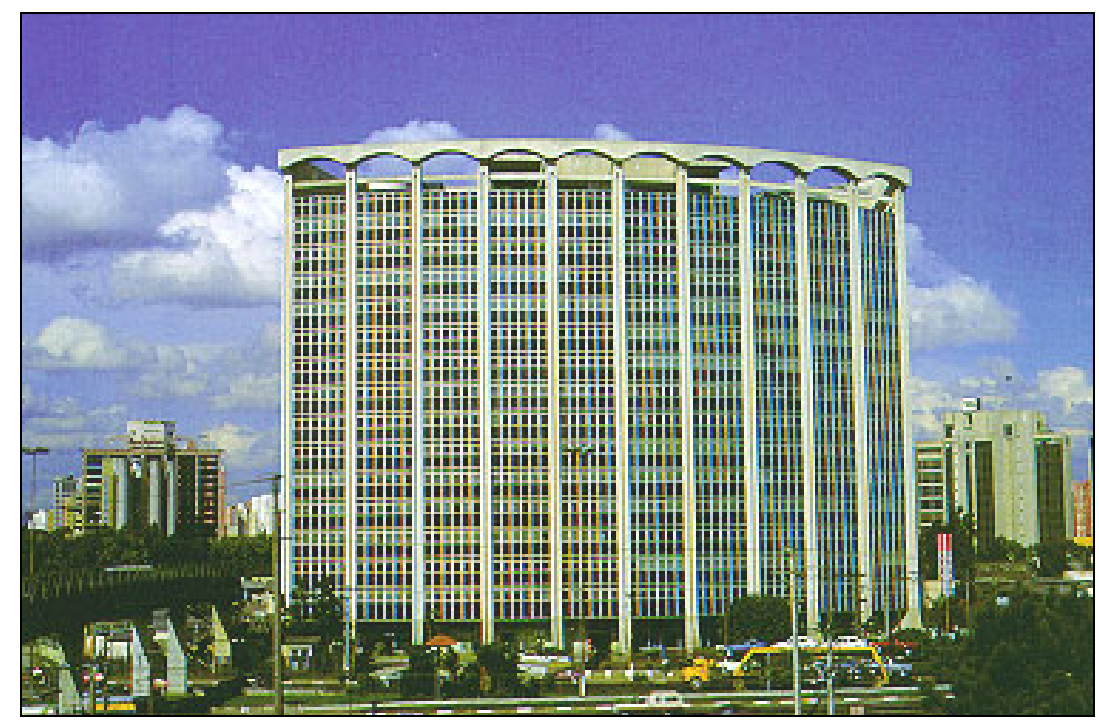

Figura 9 - Edifício Wilson Mendes Caldeira, localizado na Av. Nações Unidas - São Paulo ${ }^{16}$

O estudo concluiu que o valor de locação do imóvel, após a reabilitação, passaria dos atuais $\mathrm{R} \$ 22,30 / \mathrm{m}^{2}$ para $\mathrm{R} \$ 32,73 / \mathrm{m}^{2}$; e o valor de venda passaria de $\mathrm{R} \$$ $1.628,25 / \mathrm{m}^{2}$ para $\mathrm{R} \$ 2.543,41 / \mathrm{m}^{2}$. Ou seja, a proposta de intervenção na edificação que contemplou a reabilitação dos sistemas prediais (inclusive do sistema de ar condicionado), instalação de cabeamento estruturado sobre piso técnico elevado, sistema de divisórias leves, forros de gesso acartonado e elevadores, atingiria a valorização do imóvel para locação em 46,77\% e na venda, em 56,21\%. Os números apresentados nesse estudo demonstram que os investimentos em reabilitação podem trazer ganhos efetivos aos proprietários na comercialização de seus imóveis.

Os dados levantados pelo Projeto Reabilita (2007) na execução de empreendimentos de reabilitação para Habitação de Interesse Social (HIS) na cidade de São Paulo (Tabela 2), apontam para um custo médio de produção dos empreendimentos de reabilitação superior aos empreendimentos "novos". Isso se dá, principalmente, pelo elevado custo de aquisição do imóvel.

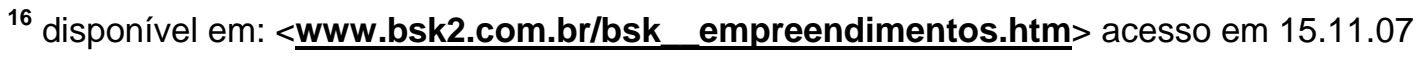


Além do fator de acréscimo de preços relativo à especulação imobiliária, gerada pelo interesse do poder público em incorporar os edifícios degradados da região central da cidade de São Paulo aos programas de reabilitação, a comparação com o custo do terreno na periferia contribui para aumentar a diferença.

\begin{tabular}{|c|c|c|}
\hline Parcela de custos & Reabilitação & Obra "Nova"18 \\
\hline Custo de produção & $\mathrm{R} \$ 455 / \mathrm{m}^{2}$ & $\mathrm{R} \$ 615 / \mathrm{m}^{2}$ \\
\hline \multicolumn{3}{|l|}{ Custo de aquisição do imóvel: } \\
\hline Região central (edifício) & $\mathrm{R} \$ 400 / \mathrm{m}^{2}$ & - \\
\hline Periferia da cidade (terreno) & - & $\mathrm{R} \$ 80 / \mathrm{m}^{2}$ \\
\hline Total & $\mathrm{R} \$ 855 / \mathrm{m}^{2}$ & $\mathrm{R} \$ 695 / \mathrm{m}^{2}$ \\
\hline
\end{tabular}

Entretanto, vale ressaltar que nesta análise não estão sendo considerados os investimentos que o poder público terá que fazer com infra-estrutura, equipamentos comunitários etc. nas duas situações.

\subsubsection{Reabilitação com mudança de uso}

Além das possibilidades de reabilitação já vistas neste capítulo, a reabilitação pode ser empregada com, pelo menos, mais uma finalidade.

Dentre as diversas formas de reabilitação de edifícios destaca-se a "mudança de uso". Esse tipo de reabilitação promove a possibilidade da edificação servir aos usuários de uma maneira diferente da que foi projetada inicialmente.

\footnotetext{
${ }^{17}$ Valores de obras "novas" baseado em dados do PAR-CEF (Programa de Arrendamento Residencial da Caixa Econômica Federal).

${ }^{18}$ Preços na data base de julho.2007.
} 
Os projetos originais são desenvolvidos para atender a uma demanda específica daquele(s) cliente(s), naquele espaço de tempo. Entretanto, as cidades, em seus processos dinâmicos de migração dos negócios que movimentam a economia local, produzem cenários distintos ao longo do tempo e em uma mesma região.

Barros e Kowaltowski (2001) sugerem que a conversão das edificações para uso residencial seja altamente recomendável, pois prolonga a vida útil dos estoques de edifícios.

Por outro lado, é comum encontrarmos bairros inteiros, projetados originalmente para o uso residencial, que passam a acolher iniciativas de ocupação para fins comerciais. Com o passar do tempo, as mudanças de uso se tornam mais evidentes e os imóveis residenciais das principais ruas, de determinado bairro, começam a abrigar empresas. Em um curto espaço de tempo, algumas ruas e avenidas acabam se transformando em corredores comerciais, provocando uma alteração no zoneamento municipal.

Na região central da cidade de São Paulo, como constata Bomfim (2004), o perfil da população (residente e flutuante) possui uma renda menor quando comparado a décadas anteriores. Essas pessoas, de média e baixa renda, que estão em busca de imóveis para moradia a um custo acessível, procuram apartamentos tipo quitinete, de um ou dois dormitórios. Este fator associado à vacância ${ }^{19}$ dos imóveis localizados no centro, é uma oportunidade para a reabilitação com mudança de uso.

Essas possibilidades, frutos da dinâmica natural das cidades, aos poucos são incorporadas às leis de zoneamento. A utilização dos imóveis projetados inicialmente para uso residencial, agora oferecem uso comercial e vice-versa. Os projetos de reabilitação possibilitam a adaptação às novas necessidades (BARRIENTOS; QUALHARINI; 2002).

\footnotetext{
${ }^{19}$ O termo vacância é definido por Bomfim (2004) como "a relação entre todos os espaços contruídos vazios e o total de espaço construído em uma determinada área".
} 
Essa versatilidade dos projetos de reabilitação fomenta os programas de revitalização de edificações dos centros das cidades, como será apresentado a seguir (Tabela 3).

Tabela 3 - Exemplos de imóveis de uso comercial convertidos em habitação de interesse social, na cidade de São Paulo (adaptado de PROJETO REABILITA, 2005)

\begin{tabular}{llc}
\hline \multicolumn{1}{c}{ Empreendimento } & Projeto Original & Projeto de Reabilitação \\
\hline Edifício Riskallah Jorge & Uso comercial & Uso habitacional (167 u.h.) \\
\hline Edifício Labor & Uso comercial & Uso habitacional (84 u.h.) \\
\hline Hotel São Paulo & Uso comercial & Uso habitacional (152 u.h.) \\
\hline
\end{tabular}

Mas a mudança de uso pode se dar não só entre tipos de utilização diferentes (comercial para residencial e vice-versa), mas também pode contemplar a mudança no adensamento de unidades habitacionais e no padrão das edificações (médio padrão para HIS, por exemplo), como apresentado na Tabela 4, abaixo:

Tabela 4 - Empreendimentos residenciais convertidos em habitação de interesse social (adaptado de PROJETO REABILITA, 2005)

\begin{tabular}{|c|c|c|c|}
\hline Local & Empreendimento & Projeto Original & Projeto de Reabilitação \\
\hline क & Edifício Maria Paula & $\begin{array}{l}\text { Uso habitacional } \\
\text { ( } 24 \text { u.h.) }\end{array}$ & Uso habitacional ( 75 u.h.) \\
\hline \multirow{4}{*}{ 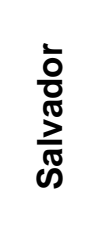 } & Casarão nº 11 - centro histórico & Casarão em ruína & Uso habitacional ( 04 u.h.) \\
\hline & Casarão n 19 - centro histórico & Casarão em ruína & Uso habitacional ( 12 u.h.) \\
\hline & Casarão n 38/40/42 - centro histórico & Casarão em ruína & Uso habitacional ( 15 u.h.) \\
\hline & Casarão nº 56 - centro histórico & Casarão em ruína & Uso habitacional ( 06 u.h.) \\
\hline \multirow{3}{*}{$\widetilde{\Upsilon}$} & Casarão nº 20 - Lapa & Casarão em ruína & Uso habitacional ( 09 u.h.) \\
\hline & Sobrado R. Senador Pompeu & Cortiço & Uso habitacional ( 23 u.h.) \\
\hline & Casarão Livramento $n^{\circ} 147$ & Casarão em ruína & Uso habitacional ( 05 u.h.) \\
\hline
\end{tabular}

Dentre as possibilidades de mudança de uso de edificações, destacam-se: edifícios residenciais antigos que foram reformados em escritórios de empresas; antigas fábricas transformadas em hipermercados (Figura 10), hotéis em edifícios residenciais, edifícios residenciais em flats etc. 


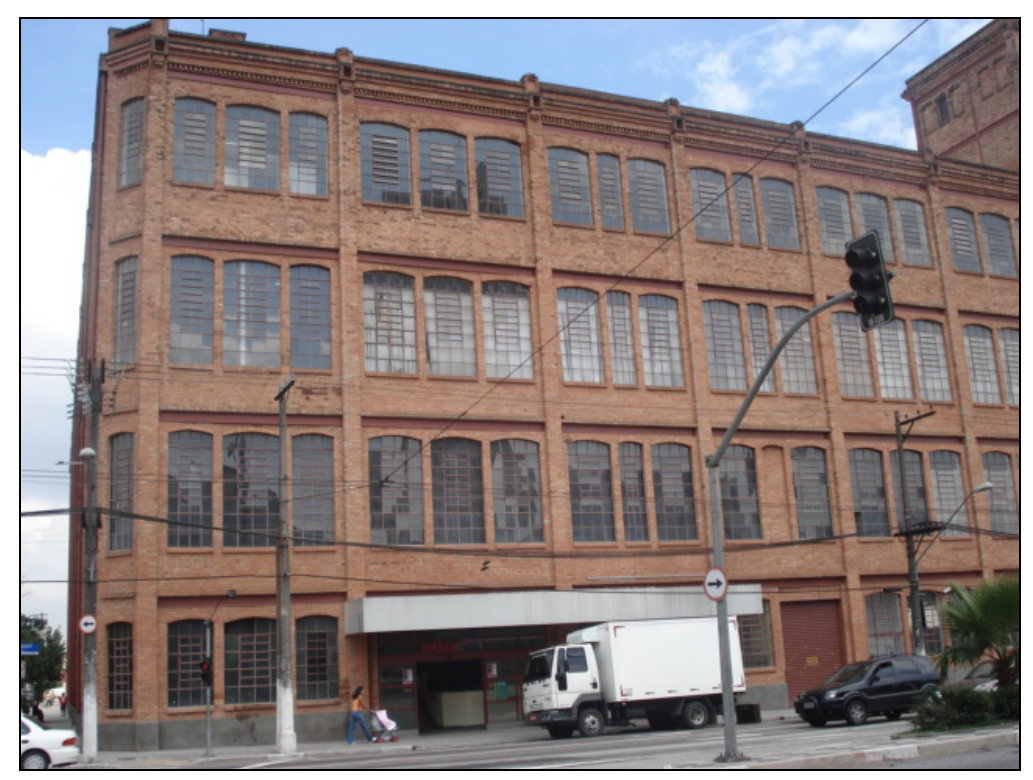

Figura 10 - Antiga fábrica têxtil convertida em hipermercado na cidade de São Paulo, SP (arquivo do autor)

Mudanças de uso podem ocorrer principalmente em função da sua localização e do modelo adotado de expansão urbanística da cidade em que se localiza. Entretanto, como ressalta Yolle (2006), as intervenções para conversão de edifícios podem variar em função da sua utilização original. A Tabela 5 destaca as principais diferenças encontradas em empreendimentos de reabilitação voltados para habitação de interesse social, quando executados em edifícios comerciais e residenciais. 
Tabela 5 - Principais diferenças na intervenção em edifícios comerciais e residenciais (adaptado de YOLLE, 2006)

Edifício Comercial

- $\quad$ Pavimentos com grandes salões, janelas apenas nas paredes externas. A subdivisão do salão em unidades habitacionais cria ambientes sem ventilação, voltados para o interior do edifício. Para solucionar a questão, são criados fossos ou corredores internos de circulação.

- O amplo salão do pavimento facilita o projeto das unidades habitacionais com as dimensões adequadas pelo arquiteto.

\section{Edifício Residencial}

- Geralmente, a construção já proporciona ventilação e iluminação natural e direta, através das janelas existentes, para as unidades habitacionais.
- $\quad$ Os caixilhos eventualmente compõem a vedação vertical ao longo de toda a fachada, com abertura em poucos locais. Isso faz com que a modulação dos ambientes seja limitada a modulação dos caixilhos.

- Foco principal: garantir a ventilação e iluminação.

- Acréscimo de cargas na estrutura devido ao reservatório superior e à execução de paredes divisórias internas.

- Maior quantidade de demolição em concreto (abertura de fossos e reforços estruturais) e menor quantidade de demolição em alvenaria e revestimentos cerâmicos (áreas molhadas).

- Aumento da reserva e consumo de água em relação às instalações originais e necessidade de criação de shafts para atender às unidades habitacionais do pavimento.

- Maior quantidade de execução de divósórias, revestimentos (inclusive pintura) e forros para esconder as novas tubulações.
- Quando há a diretriz em se produzir o menor volume de demolição possível, as divisões internas dos cômodos existentes se tornam um desafio para a adequação aos novos ambientes.

- Quando não há subdivisão dos cômodos, as janelas permanecem na posição original. Caso contrário, é necessária a criação de novas aberturas.

- $\quad$ Foco principal: adequação de áreas das unidades habitacionais.

- Eventualmente, o acréscimo de cargas é devido ao novo (e maior) adensamento do edifício.

- Menor demolição em concreto e maior em alvenaria (paredes de vedação); maior demolição dos sistemas de impermeabilização e revestimentos cerâmicos.

- Reservatório e shafts existentes.

- Maior incidência de substituição de revestimentos danificados, recuperação do substrato (Figura 11).

\section{A intensidade da intervenção de reforma em determinada edificação está diretamente relacionada ao uso e à manutenção a que foi submetida ao longo dos anos de utilização.}




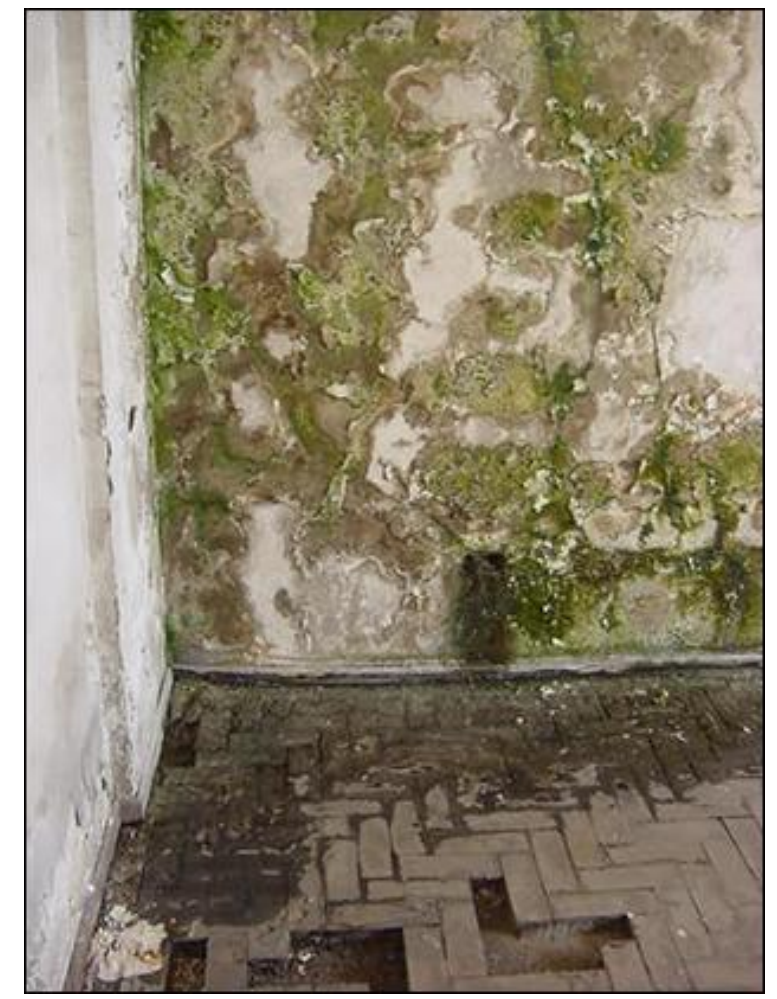

Figura 11 - Revestimento danificado devido à infiltração de água pela cobertura (arquivo do autor)

Em cidades que o mercado imobiliário residencial aponta para fora dos centros urbanos e o poder público não intervém para orientar esse movimento, a tendência é as construções ali estabelecidas passarem a ser desvalorizadas para o uso residencial.

Atualmente, empresas migram para a região central em busca de serviços de infraestrutura pública disponíveis e valores de locação mais acessíveis. Tem-se então a necessidade de mudança de uso dessas edificações. Assim, edifícios residenciais precisam ser adaptados para abrigar escritórios de empresas. Certos aspectos, tais como as instalações hidráulicas, elétricas e de gás são calculadas com critérios específicos, o que diferencia os tipos de uso que uma edificação pode receber. Remodelações de layout são imprescindíveis para otimizar os novos ambientes. 


\section{ESTUDO DA INTERFACE PROJETO - OBRA EM EMPREENDIMENTOS DE REABILITAÇÃO DE EDIFÍCIOS}

Neste capítulo será discutida a gestão de projetos de reabilitação e analisada a sua interface com a execução das obras. Além disso, serão discutidas propostas de abordagem de projetos de reabilitação que contemplam as etapas de diagnóstico e desenvolvimento dos projetos e execução das obras.

\subsection{PROJETO E OBRA DE REABILITAÇÃO NO CONTEXTO BRASILEIRO: MUDANÇA CULTURAL}

Empreendimentos que envolvem a participação de equipes multidisciplinares, que trabalham em conjunto e, em determinados momentos, atuam no projeto simultaneamente, costumam apresentar pontos de vulnerabilidade nas atividades de interface entre as diferentes áreas. Em empreendimentos de reabilitação, a interface identificada como a mais crítica é aquela entre o projeto e a obra propriamente dita.

Ao contrário de obras "novas", os empreendimentos de reabilitação demandam uma relação quase que simbiótica entre as equipes de projetos e obras, pois a interdependência entre elas é ainda maior. Em determinados momentos do empreendimento, há um estreitamento no relacionamento dessas equipes e as informações são compartilhadas de modo que, não raramente, os projetos e a execução das obras são realizados concomitantemente. Ou seja, em determinadas etapas do empreendimento os projetos são elaborados de acordo e no ritmo do desenvolvimento da execução das obras de reabilitação.

As demandas apresentadas às equipes de um empreendimento de reabilitação podem suplantar a previsão inicial feita por elas. Nesse momento, se o foco das equipes não estiver direcionado aos interesses do cliente, mas, sim, unicamente aos limites definidos nos instrumentos contratuais, poderá haver descompasso na 
execução do empreendimento. Lana e Andery (2001) entendem que esse modelo integrado de atuação das equipes exige, dos profissionais envolvidos, uma visão holística do empreendimento e foco orientado ao cliente final e não ao contrato. Como afirmam os autores, para que seja possível a integração efetiva entre as equipes de projeto e obras, é necessária uma mudança de cultura.

Essa mudança de cultura passa por não apenas a relação entre as diversas equipes envolvidas no empreendimento, mas também pelas atividades-fim de cada uma delas, como por exemplo: as atividades de projeto, o fluxo dos processos, os elementos fundamentais para a elaboração dos projetos, a rotina de desenvolvimento, a elaboração do partido arquitetônico, as interferências técnicas com outras disciplinas de projeto etc.

Para Roders (2006) pode ser um engano pensar que um excelente projetista de empreendimentos "novos" ou convencionais tenha sucesso em um empreendimento de reabilitação. Segundo a autora, isso só acontece quando este projetista já adquiriu os valores de sustentabilidade ambiental (reutilização dos recursos), preocupa-se com a longevidade das edificações e com o seu valor histórico e cultural. Ou seja, isso requer uma mudança cultural.

\subsection{O PROCESSO DE PROJETO NA REABILITAÇÃO DE EDIFÍCIOS}

Arantes (2001) reconhece a primeira e mais evidente mudança conceitual encontrada em empreendimentos de reabilitação: "trabalhar com reabilitação implica em trabalhar sobre um projeto de outro autor".

Roders (2006) identifica que, dependendo da maneira como o projeto original foi concebido em termos de longevidade da edificação, o projetista de reabilitação, além de ter que desenvolver um novo conceito sobre algo que já passou por um processo de projeto anteriormente, terá que saber lidar também com as intervenções feitas posteriormente. 
Bonanni (2000) complementa: "o edifício é ainda o que inspira os limites e regulamenta as intenções de uma reutilização acertada". Naturalmente, os empreendimentos de reabilitação podem ter diferentes graus de intervenção ${ }^{20}$. Independentemente da complexidade, o projeto de reabilitação será, necessariamente, desenvolvido a partir e sobre uma construção existente, ou seja, sobre o projeto de outros autores.

Appleton (2003) afirma que embora esta prática seja freqüente, não se pode projetar "sobre" um edifício "como se ele não existisse". Embora os projetistas não estejam totalmente livres para criar, "a liberdade que resta é suficiente" e as restrições impostas pela edificação não podem comprometer a qualidade dos projetos de intervenção.

O Projeto Reabilita (2007) destaca outro aspecto importante a ser considerado no projeto de reabilitação: "as edificações foram construídas a partir de legislação vigente no momento da elaboração do projeto e a execução das obras, sob um contexto de necessidades e soluções também específicas".

O grau de complexidade é acentuado nos empreendimentos que envolvem mudança ou readequação de uso. Algumas iniciativas de reabilitação de edificações degradadas, localizadas no centro das capitais brasileiras, têm sido percebidas. Em certos casos, o objeto de reabilitação são edifícios residenciais antigos que serão reprojetados para um adensamento maior de unidades habitacionais.

Esses empreendimentos, parte deles voltados à habitação de interesse social, promovem a mudança completa do pavimento-tipo aumentando substancialmente o número de unidades e, portanto, provocando a descaracterização interna completa do imóvel.

Esse tipo de reabilitação causará impacto em praticamente todas as disciplinas de projeto, desde a redistribuição de cargas da estrutura, devido às novas divisões internas, até os sistemas prediais que serão totalmente modificados.

\footnotetext{
${ }^{20}$ Será apresentado, no item 4.1, uma definição para os diferentes graus de intervenção.
} 
Segundo Silva (2004), os principais requisitos técnicos que devem ser atendidos para que haja interesse do empreendedor na reabilitação de um empreendimento são:

* adequabilidade do espaço disponível ao programa;

* viabilidade de se conter entre duas lajes os espaços de uso-fim e os dispositivos mecânicos (sistemas de ar condicionado e tubulações em geral);

* compatibilidade do invólucro com as necessidades de conforto ambiental; e

* estabilidade e integridade da edificação.

Eventualmente, as soluções adotadas pelos projetistas originais dificultam as soluções da reabilitação. O traçado das vigas da estrutura da edificação, por exemplo, dificulta um eventual caminhamento dos sistemas prediais por um forro que poderia ser criado. E todas as soluções precisam ser desenvolvidas à luz da readequação às exigências legais e necessidades modernas de automação, sistemas prediais e flexibilidade de uso dos ambientes etc.

Mas, além das equipes de projetos terem de conviver com as soluções adotadas pelos projetistas originais, no sentido de serem fatores limitantes no processo criativo, elas devem entender que se tratam de informações imprescindíveis para desenvolvimento das novas soluções de reabilitação.

Ao contrário dos empreendimentos "novos" (ou convencionais), os de reabilitação possuem características específicas que refletem um padrão de processos totalmente diferente. Esse novo desenho dos processos influencia a produtividade de execução de projetos e obras, impacto nos custos, nos prazos etc. Por esse motivo, quer seja sob o ponto de vista do prazo, do custo ou da qualidade, os resultados esperados precisam ser dimensionados levando-se em conta as características específicas e os riscos envolvidos nesse tipo de empreendimento.

A expectativa de resultados das intervenções em empreendimentos de reabilitação não pode ser a mesma associada a empreendimentos novos. Nestes últimos, as variáveis envolvidas são amplamente conhecidas e estudadas e há domínio da padronização de procedimentos e técnicas executivas que reduzem 
substancialmente os riscos. Em empreendimentos de reabilitação, por sua vez, a padronização e o detalhamento dos processos muitas vezes são bastante complexos.

Dessa forma, os contratos com as diversas equipes envolvidas no empreendimento não devem ser feitos nos mesmos moldes dos contratos de empreendimentos "novos". Os índices de produtividade, o grau de dedicação etc. são muito diferentes. Isso inclui as condições contratuais estabelecidas entre os agentes. A modalidade contratual, a descrição do escopo etc. são fatores importantes para se notar nesse tipo de negócio.

Os termos contratuais estabelecidos entre uma empresa de projeto e a empresa incorporadora, por exemplo, podem impactar diretamente nos resultados esperados por ambas as partes, caso eles não estejam alinhados com a realidade de empreendimento de reabilitação e, ainda, com as particularidades daquele objeto contratual específico. Torna-se imprescindível a compreensão do processo pelos diferentes agentes envolvidos (FREITAS; SOUZA, 2003).

Quer seja pela carência de legislação específica para empreendimentos de reabilitação, quer seja por situações não previstas na etapa de diagnóstico, a dedicação das equipes de projeto tende a ser maior se comparada a obras novas. $O$ processo contínuo de revisão e atualização do projeto em virtude das interferências encontradas no canteiro de obras e, no caso do empreendimento pertencer a algum programa de investimento público, haverá a necessidade de um trabalho conjunto com os técnicos de análise de aprovação financeira. Esses fatores representam um custo adicional ao projeto.

Todas as relações contratuais estabelecidas no empreendimento, entre o incorporador e o(s) proprietário(s) do imóvel, entre a empresa construtora e a incorporadora, entre as empresas projetistas e os clientes etc. podem se tornar conflituosas caso as condições estabelecidas inicialmente não tenham sido desenhadas sob medida para aquela situação. 
Por outro lado, o grau de incerteza está diretamente relacionado à qualidade do conhecimento que se tem do empreendimento. Os riscos diminuem proporcionalmente à quantidade e à qualidade das informações que são obtidas no início das atividades. As decisões tomadas nas primeiras etapas do empreendimento são cruciais. Especialmente nas etapas preliminares, as decisões mais importantes irão impactar o resultado final do empreendimento em termos de flexibilidade, eficiência e eficácia (DE GROOT, 1999 apud RODERS, 2006).

Mais uma vez, a mudança de cultura se mostra importante para proporcionar um ambiente estável na execução do empreendimento. Independentemente do tipo de empreendimento, "novo" ou reabilitação, a cultura atual brasileira orienta ao mínimo investimento inicial no empreendimento.

Roders (2006) propõe uma metodologia de processo de projeto dividida, basicamente, em dois estágios: "pre-design" e "design", conforme ilustra a figura 12:

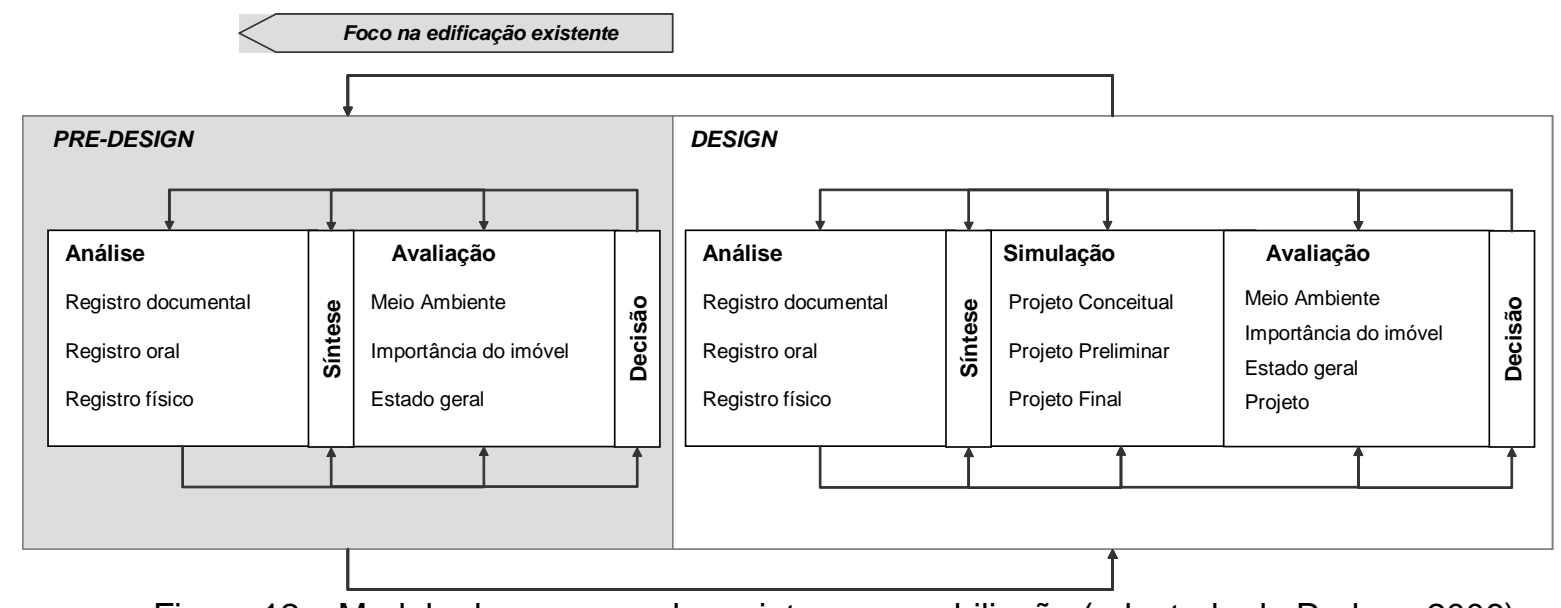

Figura 12 - Modelo de processo de projeto para reabiliação (adaptado de Roders, 2006)

Segundo a autora, o pre-design é o estágio orientado para o edifício, onde o foco principal do projetista será a construção existente e o meio no qual está inserido, sem se preocupar, num primeiro momento, com o programa de necessidades do empreendimento.

Roders (2006) defende que este é o estágio mais importante para que um empreendimento de reabilitação seja bem sucedido, pois é nesse momento que serão desenvolvidas as atividades de investigação. Os frutos destas atividades 
serão dados concretos a respeito da edificação e do seu entorno, os quais darão subsídios para as decisões de projeto, podendo-se evitar enganos. A autora sugere que, mesmo nos casos em que não é possível desenvolver todas as etapas deste estágio, devido à falta de recursos no cronograma ou no orçamento, elas devem ser desenvolvidas com alta qualidade, ainda que parcialmente, pois agregarão valor à etapa de desenvolvimento do projeto.

Importante salientar que a etapa de pre-design é exclusiva para empreendimentos de reabilitação. Diferentemente dos empreendimentos novos ou convencionais, a reabilitação demanda uma etapa de entendimento da edificação existente. Os dados coletados servirão de base para as atividades subseqüentes de elaboração do projeto. Percebe-se, portanto, a necessidade de uma coordenação de projetos atuando desde o início do empreendimento. Além de promover a gestão de projetos, ela poderá, desde o início, identificar os potenciais entraves do empreendimento.

\subsubsection{Etapa de investigação e diagnóstico}

Segundo Appleton (2003), "parece evidente que, em primeiro lugar, é necessário se conhecer completamente o objeto de intervenção e definir um programa base para essa intervenção, ou seja, o que se tem como edifício e o que se deseja ter desse edifício".

Para Roders (2006), o projetista deve se colocar diante da edificação a ser reabilitada como "um médico que examina o seu paciente". Sem uma análise detalhada do paciente, não será possível realizar um diagnóstico ou, sequer, definir um tratamento adequado para aquela situação. A autora questiona: "como uma intervenção pode ser projetada e planejada sem um exame profundo e detalhado do 'paciente'?" referindo-se à analogia do projetista como médico e a edificação, a ser reabilitada, como o paciente. 
Na figura 12, o estágio pre-design é subdividido em quatro etapas: análise, síntese, avaliação e decisão. Na etapa de análise, deverão ser levantadas e registradas todas as informações pertinentes ao edifício e ao meio em que está inserido.

Basicamente, essas informações devem ser coletadas através de:

i. pesquisa em documentos (em órgãos públicos, concessionárias, cartórios de registro, bibliotecas etc.);

ii. entrevistas (com ocupantes, vizinhança, proprietário do imóvel, operários etc.); e

iii. levantamentos de dados dos materiais, componentes e dimensões da edificação.

Estrutura semelhante de análise é proposta por Australia ICOMOS (1999) ${ }^{21}$, na etapa de entendimento da relevância das edificações no processo de conservação de construções com valor cultural.

Nesta etapa, uma boa coordenação de projetos é importante para que a busca seja bem orientada e não se perca em um "universo de dados e informações", e para facilitar as atividades, da próxima etapa, a de síntese - que consiste em filtrar, organizar e converter as informações relevantes em um levantamento útil e objetivo.

De posse destas informações, é realizada a avaliação das melhores alternativas de projeto sob a ótica de meio ambiente, importância do imóvel e do seu estado de conservação. A etapa de decisão consiste na documentação das alternativas selecionadas.

Para Fontenelle (2002), certas empresas construtoras e incorporadoras no Brasil ainda não foram despertadas para a importância de se investir nas etapas preliminares do empreendimento, principalmente naquelas relacionadas às atividades de projeto e que terão reflexos diretos no desempenho do edifício.

\footnotetext{
${ }^{21}$ Disponível em: http://www.icomos.org/australia/burra.html. Acesso em 16.11.2007.
} 
Segundo Melhado (1994), em países mais adiantados, o tempo destinado ao desenvolvimento dos projetos é, muitas vezes, da mesma ordem de grandeza do tempo dedicado à execução da obra, procurando-se, com isto, evitar as deficiências e os desperdícios comuns na fase de execução, além de obter um melhor desempenho do produto final.

$\mathrm{Na}$ França, por exemplo, existem legislações e normatizações técnicas que praticamente obrigam a realização da etapa de diagnóstico, além da necessidade de que os edifícios reabilitados sejam adequados às legislações e à normatização técnica em vigor quanto à segurança (estrutural e ao fogo) e à habitabilidade. A análise da possibilidade, ou não, de readequar este empreendimento às normas em vigor, também integra a etapa de diagnóstico e estudos de viabilidade (FRANÇA, LOI MOP).

Para Manso (2006), as etapas preliminares de um empreendimento devem conter a consulta aos órgãos fiscalizadores federais, estaduais e municipais, de meio ambiente, concessionárias de serviços públicos, além de condições locais, como riscos de enchentes, interferências com vizinhos, condições das vias de acesso, condições geológicas (por sondagens), risco de passivo ambiental, entre outros.

Segundo Freitas e Souza (2003), por melhor que seja a qualidade dos trabalhos realizados nas etapas de diagnóstico, sempre é possível encontrar problemas na etapa de execução das obras em função de interferências não previstas anteriormente. Porém, acredita-se que quanto menos eficiente é a etapa de diagnóstico, maior a probabilidade da existência de problemas na etapa de execução.

A metodologia para elaboração de projetos de reabilitação de edifícios proposta por Freitas e Souza (2003) prevê as seguintes atividades na etapa de "estudo de diagnóstico":

o análise dos documentos técnicos disponíveis; 
o aplicação de questionários aos usuários da edificação para coleta de informações, que ajudem na caracterização do estado de degradação das edificações;

o visitas aos locais mais afetados pela degradação e levantamento detalhado das patologias identificadas, assim como análise do comportamento dessas patologias;

- levantamento fotográfico da edificação e das patologias identificadas;

o medições diversas realizadas na edificação, tais como: medição de fissuras e análise da sua movimentação; temperatura e umidade dos ambientes etc. e realização de ensaios tecnológicos;

o inspeção nas fachadas do edifício, para verificação do tratamento das pontes térmicas, ligação da caixilharia, do revestimento externo etc.

Os autores sugerem a estrutura de relação entre os intervenientes do empreendimento de reabilitação apresentada na figura 13. Propõem, ainda, que essa etapa seja documentada e consolidada em um parecer no formato de relatório, contemplando, além do detalhamento de toda estrutura a ser reabilitada, as causas e tratamentos para as patologias identificadas, assim como metodologia de correção e custo previsto para a execução dos trabalhos. 


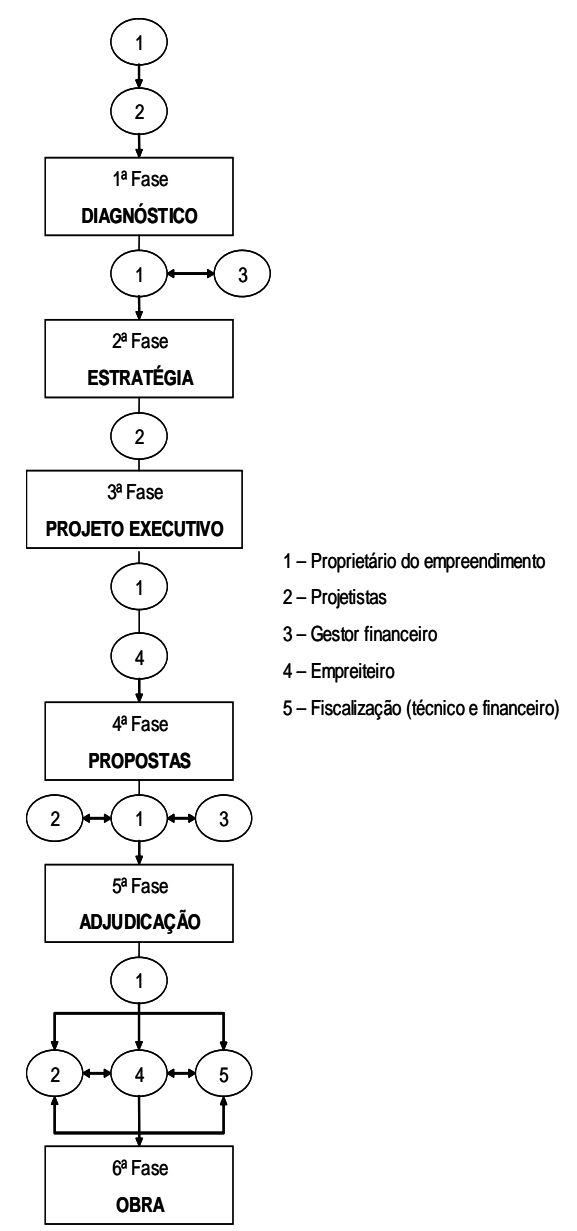

Figura 13 - Esquema da relação dos intervenientes nas diferentes fases do processo de reabilitação (FREITAS e SOUSA, 2003)

O Projeto Reabilita (2007) sugere um modelo com quatro fases para o processo de reabilitação voltado para Habitação de Interesse Social - HIS, descritas na Tabela 6. A etapa de diagnóstico proposta deverá realizar a identificação das características urbanas do imóvel, ou seja, identificar a localização geográfica na malha urbana, bem como as características gerais e específicas do entorno. Além disso, sugere que seja feita a caracterização da propriedade (levantamento da situação jurídica, tributária e financeira) e a identificação dos agentes envolvidos no empreendimento e do papel que cada um deverá desempenhar. 
Tabela 6 - Fases do processo de reabilitação (adaptado de PROJETO REABILITA, 2007)

\begin{tabular}{ll}
\hline $\mathbf{1}$ & Diagnóstico da situação física, legal e social \\
\hline 1.1 & Identificação das características urbanas do imóvel \\
\hline 1.2 & Caracterização da propriedade \\
\hline 1.3 & Identificação dos agentes envolvidos e o seu papel no empreendimento \\
\hline
\end{tabular}

\begin{tabular}{ll}
\hline $\mathbf{2}$ & Elaboração do projeto de reabilitação \\
\hline 2.1 & Inspeção e caracterização da edificação \\
\hline 2.2 & Levantamento dos parâmetros e diretrizes para elaboração de projeto \\
\hline 2.3 & Análise de viabilidade ao detalhamento do projeto \\
\hline 2.4 & Aprovaçães do projeto junto aos órgãos competentes \\
\hline
\end{tabular}

\begin{tabular}{ll}
\hline 3 & Planejamento e gestão da produção \\
\hline 3.1 & Planejamento da obra \\
\hline 3.2 & Execução e acompanhamento da obra \\
\hline 3.3 & Conclusão da obra e sua regulamentação do condomínio \\
\hline
\end{tabular}

\section{Gestão da ocupação}

O processo é concluído com a regulamentação do condomínio, a organização e planejamento das atividades de manutenção periódicas, serviços rotineiros e de melhoria. Estas últimas fazem parte da etapa chamada "gestão da ocupação", fundamental para empreendimentos de $\mathrm{HIS}^{22}$.

Para Appleton (2003) a etapa de diagnóstico deve apresentar soluções construtivas e um registro sistemático das anomalias. Além disso, deve conter uma avaliação do estado de conservação do edifício como um todo e de seus elementos, componentes e instalações. As soluções tecnológicas de intervenção no edifício apresentadas devem ser consideradas como "ponto de partida essencial para a elaboração do projeto de reabilitação".

O conhecimento das informações relativas ao empreendimento, dos elementos a reabilitar, das necessidades atuais e das limitações do produto compõem a estrutura principal de prospecções para um diagnóstico adequado.

\footnotetext{
${ }^{22}$ Será apresentado no item 5.1 um estudo de caso realizado em empreendimento de reabilitação voltado para Habitação e Interesse Social - HIS, localizado no centro da cidade de São Paulo.
} 
Entretanto, grande parte dos objetos de intervenção no parque edificado é constituída por imóveis antigos que, muitas vezes, não dispõem da documentação necessária para uma análise adequada das características técnicas das edificações. Os elementos gráficos mais freqüentemente localizados são os documentos legais que, além de não apresentarem informações específicas detalhadas, muitas vezes não refletem o estado atual das edificações.

Roders (2006) destaca que, freqüentemente, os documentos não existem, foram perdidos ou parcialmente destruídos. Além disso, quando existem os projetos "legais", não estão atualizados de acordo com as últimas alterações da construção.

Em diversas vistorias realizadas por este autor em edificações antigas na Grande São Paulo, foram encontrados projetos "legais" em desacordo com o executado. Além da ausência de área de garagem prevista em projeto, por exemplo, é relativamente comum, em edificações antigas, serem encontradas diferenças entre as dimensões da lâmina executada em relação ao previsto no projeto original.

Segundo Barrientos (2004), no Brasil não há regulamentação específica que obrigue a preservação da documentação pelos proprietários das edificações e, portanto, muitas informações acabam se perdendo ao longo do tempo. Roders (2006) comenta que na Holanda há um sistema nacional de cadastro de documentos que disponibiliza as informações dos imóveis através da internet. A pesquisa é feita pelo endereço do imóvel e o projetista pode adquirir qualquer documento que esteja disponível no arquivo. Além disso, em Portugal, há outro ambiente na internet ${ }^{23}$ para consulta pública a documentos.

Mesmo quando são localizadas as documentações técnicas, outro desafio se apresenta para os projetistas: o processo constante de alterações efetuadas na edificação, pelos seus ocupantes.

Além da possibilidade do projeto original não ter sido atendido em sua plenitude e, portanto, a construção ter sido executada em desacordo com o projeto, ao longo do

\footnotetext{
${ }^{23}$ Disponível em: http:/lisboainteractiva.cm-lisboa.pt. Acesso em: 15.nov.07.
} 
tempo melhorias e alterações das características originais são aplicadas às construções. Dentre essas alterações, encontram-se soluções pontuais para suprir eventuais deficiências do projeto original e soluções para atender às demandas atuais dos ocupantes da edificação. Os sistemas prediais são foco principal desse tipo de intervenção.

A criação de novos pontos de alimentação de energia nos cômodos dos apartamentos e nas dependências da edificação, por exemplo, é uma situação típica de descaracterização do projeto original (Figura 14). Segundo Ducap, Oriolli e Qualharini (2001), na cidade do Rio de Janeiro, a principal intervenção das obras de reabilitação está nas instalações hidro-sanitárias dos edifícios.

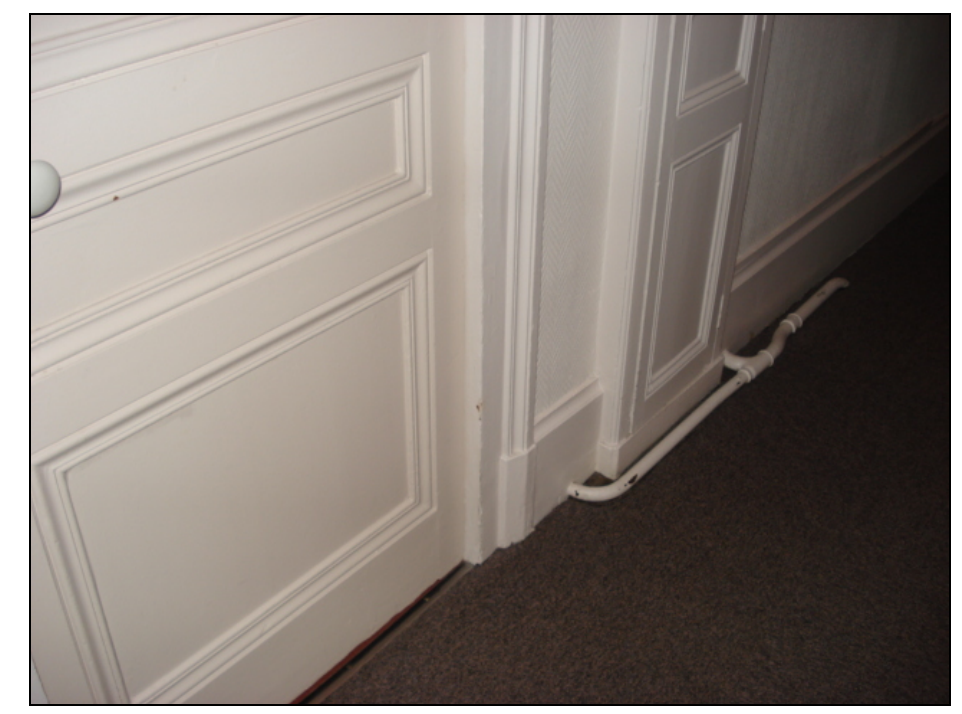

Figura 14 - Instalação hidráulica adaptada em edifício, na cidade de Lyon, França (arquivo do autor)

Além disso, podem ser listadas inúmeras possibilidades de alterações praticadas que alteram os projetos originais, tais como: execução de instalações de ventilação de tubulações; instalações externas de alimentação de gás; demolição de alvenarias de vedação internas; demolição de parte das alvenarias estruturais internas; troca de caixilhos externos com mudanças de dimensão de vãos nas fachadas; criação de sistema de alimentação de água individualizado, com instalações externas à fachada etc. 
A alteração nos projetos originais é uma prática já consagrada e não se faz privilégio de edifícios antigos. As alterações das unidades habitacionais transcendem o tempo e o padrão dos imóveis. O desejo de adaptar o imóvel às suas necessidades está presente em grande parte dos proprietários, sejam eles do mais alto ou do mais baixo nível da pirâmide social. Roders (2006) afirma que a probabilidade de um edifício passar por uma intervenção que descaracterize o projeto original é elevada, mesmo quando o imóvel se apresenta em boas condições.

Por esta razão, empresas projetistas e construtoras têm se adaptado a essa realidade e criado condições para que essas modificações de projeto ocorram antes da execução das obras. Para que isso seja possível, são desenvolvidos projetos cada vez mais versáteis e são apresentadas opções ao proprietário. A decisão por uma das alternativas deve ser feita dentro de um cronograma estabelecido pela área responsável pelas obras, de maneira a não comprometer os prazos do empreendimento.

Uma das empresas que participaram do estudo de caso, que será apresentado a seguir, é uma empresa incorporadora que executa a coordenação de projetos com equipe própria. Para conciliar o desejo de seus clientes com as possibilidades de projeto, ela solicita às empresas até 15 opções diferentes nos projetos de pavimento-tipo. Um departamento da empresa, especializado em personalização, atende diretamente os clientes e promove as definições de alterações que serão aplicadas aos projetos, em virtude da demanda apresentada pelos proprietários. Em um dos empreendimentos estudados haviam sido contabilizadas 181 solicitações de alteração de projetos nas 160 unidades comercializadas até então.

De forma geral, uma das vantagens desse tipo de modificação "monitorada" é que os projetistas têm total controle das operações e participam do desenvolvimento das novas alternativas. Além de preservar a garantia do produto, a versão final do projeto incorpora essas modificações e a documentação técnica fica coerente com a edificação executada. Além disso, esse processo realimenta as áreas de projeto e ajuda na identificação das demandas atuais dos usuários, para os próximos projetos. Entretanto, o processo de descaracterização do projeto original é contínuo e sua 
velocidade está relacionada aos interesses e possibilidades do usuário em adaptar a construção às suas necessidades.

Diante deste cenário de constantes alterações do projeto original, Roders (2006) sugere que na etapa de levantamento de dados sejam consultados inclusive arquivos fotográficos particulares de usuários ou de vizinhos da edificação. Essas imagens, quando comparadas com as de outras épocas, podem relatar dados importantes de intervenções feitas no passado, que podem se tornar interferências no momento da execução das obras. Além disso, podem trazer ao conhecimento do projetista detalhes de fachada, organização espacial do imóvel em outros períodos, detalhes construtivos etc.

Portanto, os levantamentos de campo são essenciais para a caracterização adequada da construção existente, e a documentação técnica poderá orientar esses trabalhos. Em outros termos, as medições in loco são imprescindíveis para qualquer atividade de desenvolvimento de projeto de reabilitação (CROITOR; OLIVEIRA; MELHADO, 2007).

Appleton (2003) afirma que o ponto de partida para um projeto de reabilitação deve ser o levantamento geométrico na etapa de diagnóstico ou a verificação de um levantamento existente. Ele deve ser realizado antes da definição dos materiais e tecnologias que serão especificados, para que seja possível a verificação da sua compatibilidade com os existentes. O levantamento geométrico possibilitará:
a. identificar irregularidades
b. indicar soluções para problemas encontrados
c. obter informações "preciosas" acerca das características construtivas do edifício

Segundo o mesmo autor, os trabalhos executados nesta etapa evitarão que soluções "necessariamente mais precárias e obrigatoriamente menos econômicas" sejam adotadas na etapa de execução das obras de reabilitação. 
Para Yolle (2006), as vistorias no imóvel devem ser realizadas no momento adequado, tendo sempre definido "como" e que "tipo" de informação deverá ser coletada. Vistoria mal planejada e executada em momentos inadequados pode resultar em desperdício de tempo e/ou em coleta de informações incompletas e inadequadas.

Roders (2006) destaca a importância da realização dos levantamentos de campo ser feita nas etapas preliminares (pre-design), pois eles podem ser completados em poucos dias e as informações obtidas podem subsidiar importantes decisões de projeto. Segunda a autora, se determinadas informações forem descobertas apenas na etapa de construção, poderá representar atrasos no cronograma e desperdícios de recursos (financeiro, de tempo, de energia, humano etc.). Além disso, especialmente quando não há mais tempo para o projetista retornar ao escritório e reestruturar o desenvolvimento do projeto, ele acaba sendo forçado a adotar soluções improvisadas que, além de precárias do ponto de vista técnico, acabam sendo menos econômicas.

Segundo Barrientos (2004), a análise detalhada das informações coletadas nessa etapa, aliada à investigação de documentos e desenhos existentes, orientará a decisão de reabilitação.

Appleton (2003) sugere que o diagnóstico seja realizado sob a forma de um parecer técnico e, de preferência, por profissioais experientes e especializados em reabilitação. O autor destaca ainda a importância do acompanhamento do(s) autor(s) do projeto de reabilitação nesta etapa.

Outro recurso importante nessa etapa investigativa é a aplicação de questionários aos ocupantes da edificação, caso seja possível. As entrevistas, que podem ser formais ou não, são importantes fontes de informação e possibilitam: a compreensão de algumas intervenções realizadas pelos ocupantes na edificação; a identificação das práticas de manutenção aplicadas nos últimos tempos; a identificação de pontos críticos de degradação ainda não conhecidos da equipe de projetos; o estado de conservação atual das edificações; a rotina de utilização das instalações; o desempenho dos sistemas prediais atuais etc. 
Freitas e Sousa (2003) sugerem que esses questionários sejam simples e que não necessitem de conhecimento técnico para que sejam respondidos. O objetivo principal deve ser o de identificar os locais mais degradados para inspecioná-los, posteriormente, e capturar as expectativas dos ocupantes da edificação.

Ainda durante a fase de diagnóstico do empreendimento a ser reabilitado, podem ser identificadas particularidades do objeto de intervenção que influenciam diretamente as decisões de projeto. Uma vez que o diagnóstico seja bem executado e apresente um retrato fiel das condições reais das edificações, essa investigação poderá antecipar eventuais falhas de projeto com impacto direto em todas as demais etapas do empreendimento. A etapa de diagnóstico, ilustrada na Figura 15, é compreendida pelo processo de avaliação e identificação do estágio de degradação e da capacidade regenerativa da edificação ou micro-região (BARRIENTOS, 2004).

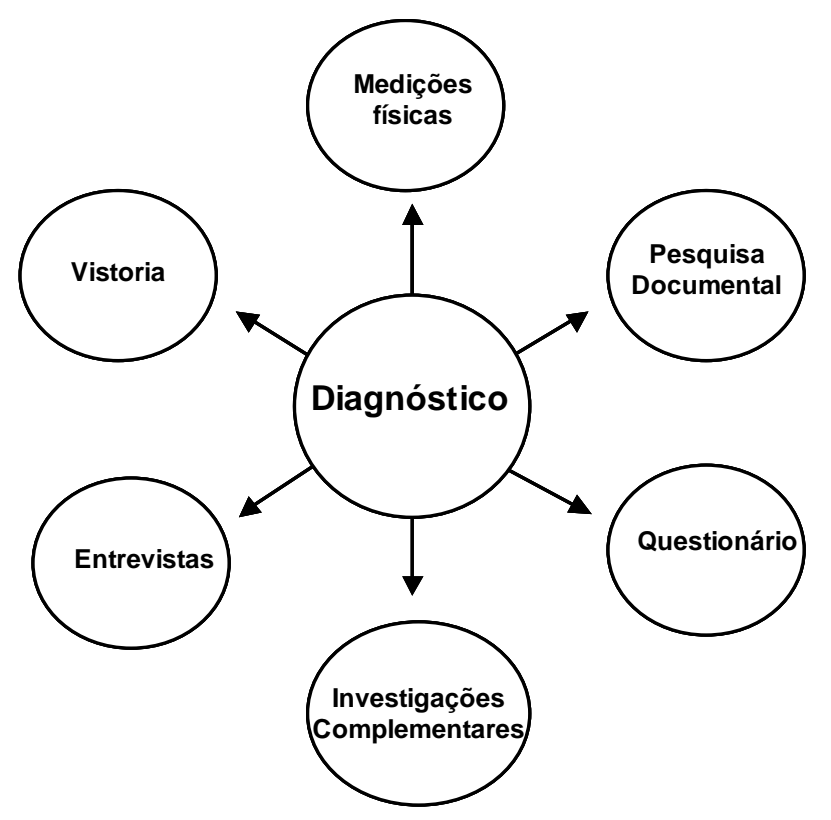

Figura 15 - Atividades da etapa de diagnóstico (BARRIENTOS, 2004)

Yolle (2006) propõe uma metodologia de abordagem de empreendimentos potenciais para reabilitação e conversão do uso para Habitação de Interesse Social (HIS), cuja etapa técnica de viabilidade está ilustrada na Tabela 7. Segundo o autor, essa metodologia, desde que adaptada, pode ser aplicada a qualquer tipo de empreendimento de reabilitação. 
Tabela 7 - Etapa técnica de viabilidade de um empreendimento (adaptado de YOLLE, 2006)

Etapa Técnica

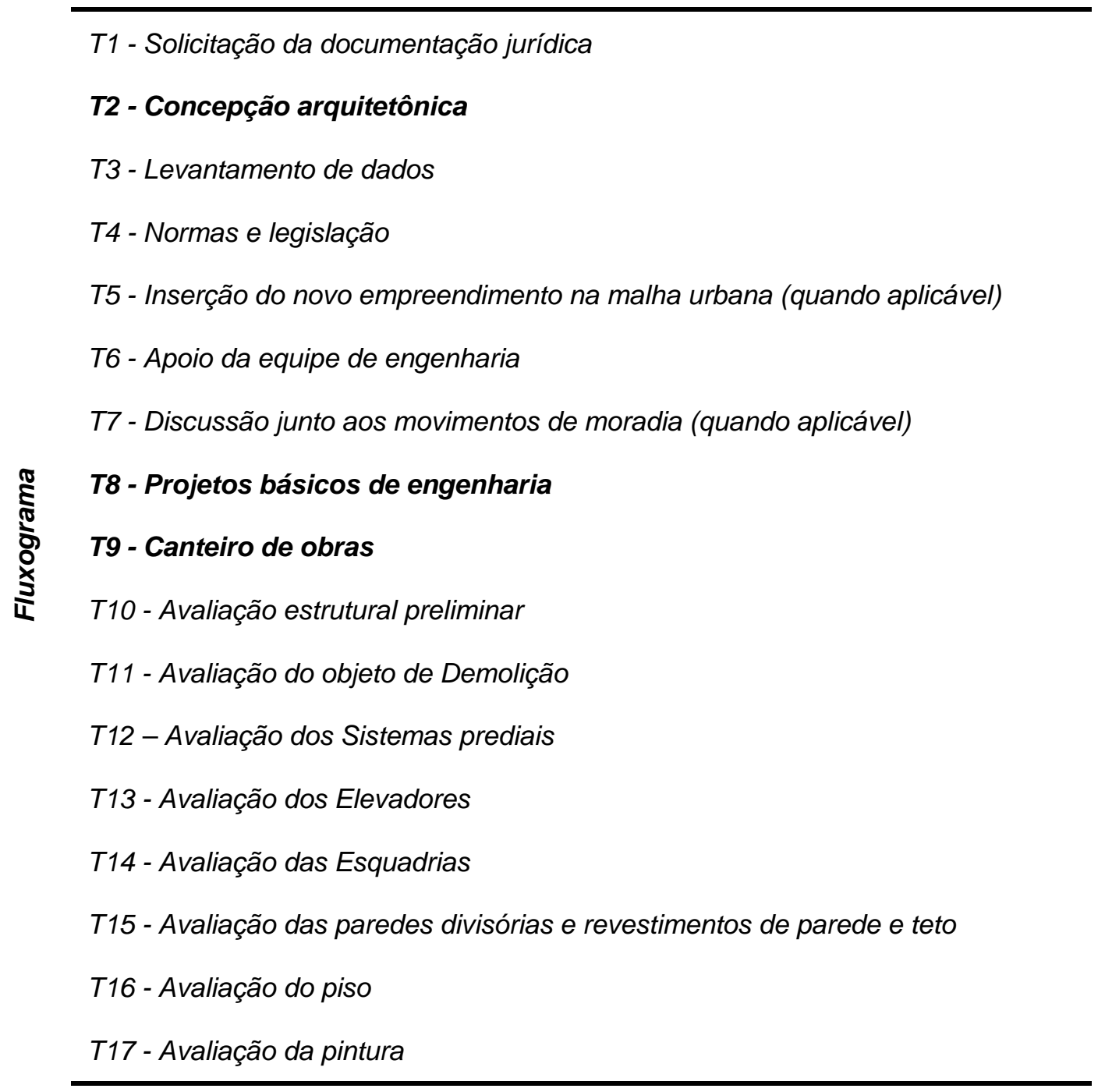

Ao contrário de Roders (2006), a proposta de Yolle considera o desenvolvimento dos projetos conceituais e básicos e o planejamento do canteiro de obras (atividades T2, T8 e T9), como sendo atividades preliminares que acontecem na etapa de diagnóstico.

Para Roders (2006), essas atividades deveriam acontecer apenas na etapa subseqüente de desenvolvimento de projetos. Segundo a autora, a etapa preliminar deve se restringir à investigação da edificação existente e do seu entorno ("building oriented"), e os aspectos do projeto de reabilitação devem ser tratados na etapa subseqüente, após o conhecimento das limitações e condições da edificação e do seu entorno, como será apresentado a seguir. 
Em sua pesquisa, Yolle relaciona e detalha os principais itens que devem ser avaliados para as principais atividades da etapa técnica. A primeira é a solicitação de documentação jurídica que, eventualmente, pode ser realizada concomitantemente com a concepção arquitetônica. Esta etapa visa garantir que não haverá nenhum impedimento legal para a reabilitação da edificação e evita, assim, que os trabalhos técnicos, daí em diante, sejam desperdiçados.

A atividade de levantamento de dados consiste em obter qualquer informação do empreendimento relacionada ao seu histórico, tais como: plantas originais, levantamentos cadastrais, obras que foram executadas nos empreendimento após a sua operação etc.

As atividades de apoio das equipes de engenharia, segundo Yolle (2006), são o suporte especializado que as demais disciplinas de projeto, eventualmente, precisam dar à equipe que estará desenvolvendo o projeto conceitual de arquitetura. $\mathrm{O}$ objetivo é fornecer dados complementares que auxiliem na escolha da melhor solução arquitetônica possível de ser executada.

De posse das questões legais equacionadas e do projeto conceitual de arquitetura desenvolvido, realiza-se a chamada atividade de desenvolvimento dos projetos básicos de engenharia. Para o autor, nessa etapa os projetos complementares serão desenvolvidos e compatibilizados.

No que diz respeito ao planejamento do canteiro de obras, dificuldades podem ser encontradas. Geralmente, os edifícios antigos não oferecem áreas livres suficientes (Figura 16), o que dificulta, além do acesso ao interior da edificação, o abastecimento de suprimentos, o armazenamento de materiais, podendo gerar retrabalho e até perda de material. 

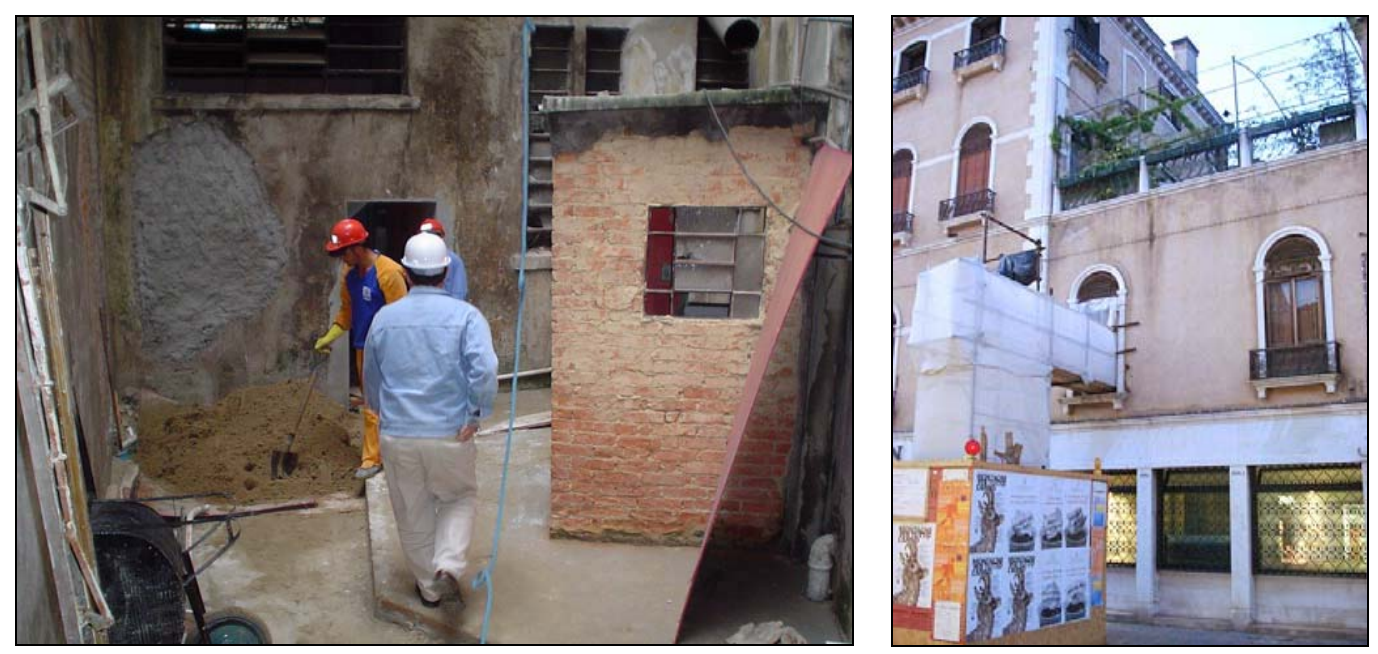

Figura 16 - Canteiros e acessos em edifícios antigos em São Paulo-SP e Veneza, Itália (arquivo do autor)

Quando os edifícios estão localizados em regiões centrais de grandes cidades, outro fator que dificulta o planejamento do canteiro é a restrição de tráfego de caminhões para entrega de materiais e equipamentos (PROJETO REABILITA, 2007).

A avaliação estrutural preliminar deve ser realizada de maneira a garantir que as novas cargas, que serão aplicadas à edificação, estarão dentro da capacidade de suporte da estrutura existente. Portanto, os ensaios de integridade e resistência devem estar previstos nessa atividade.

Nas atividades T11 a T17, o autor detalha minuciosamente como devem ser feitas as avaliações de campo. Após concluídas as avaliações, será possível calcular o orçamento básico do empreendimento de reabilitação. Os dados coletados nas etapas de investigação servirão como dados de entrada para o processo de desenvolvimento dos projetos de reabilitação do empreendimento.

Após a realização adequada da etapa de investigação e diagnóstico, será possível identificar o que pode ser aproveitado da edificação existente e o que deve ser reparado ou substituído. Somente então, será possível iniciar a etapa de elaboração de projetos (Aguiar et al apud Roders, 2006). 


\subsubsection{Etapas de desenvolvimento de projetos de reabilitação}

Como lembra Melhado (2002) "o projeto não pode ser entendido como uma simples entrega de desenhos e memoriais; muito mais do que isso, espera-se que esse projetista esteja, antes de mais nada, comprometido com a busca de soluções para os problemas dos seus clientes". No caso de empreendimentos de reabilitação de edifícios, dada a sua complexidade, essa busca de soluções se estenderá desde a etapa de projeto até a execução das obras.

Roders (2006) define o estágio denominado design, apresentado na

Figura 17, como sendo um conjunto de atividades orientadas pela perspectiva da reabilitação (rehabilitation-oriented). Isto é, ao contrário do estágio anterior (predesign) - onde a orientação das atividades não levava em conta o programa de necessidades, mas apenas a edificação existente e seu entorno - nesta etapa, as equipes de projeto buscarão a compatibilidade entre a construção existente (edifício) e a que se deseja construir (projeto de reabilitação).

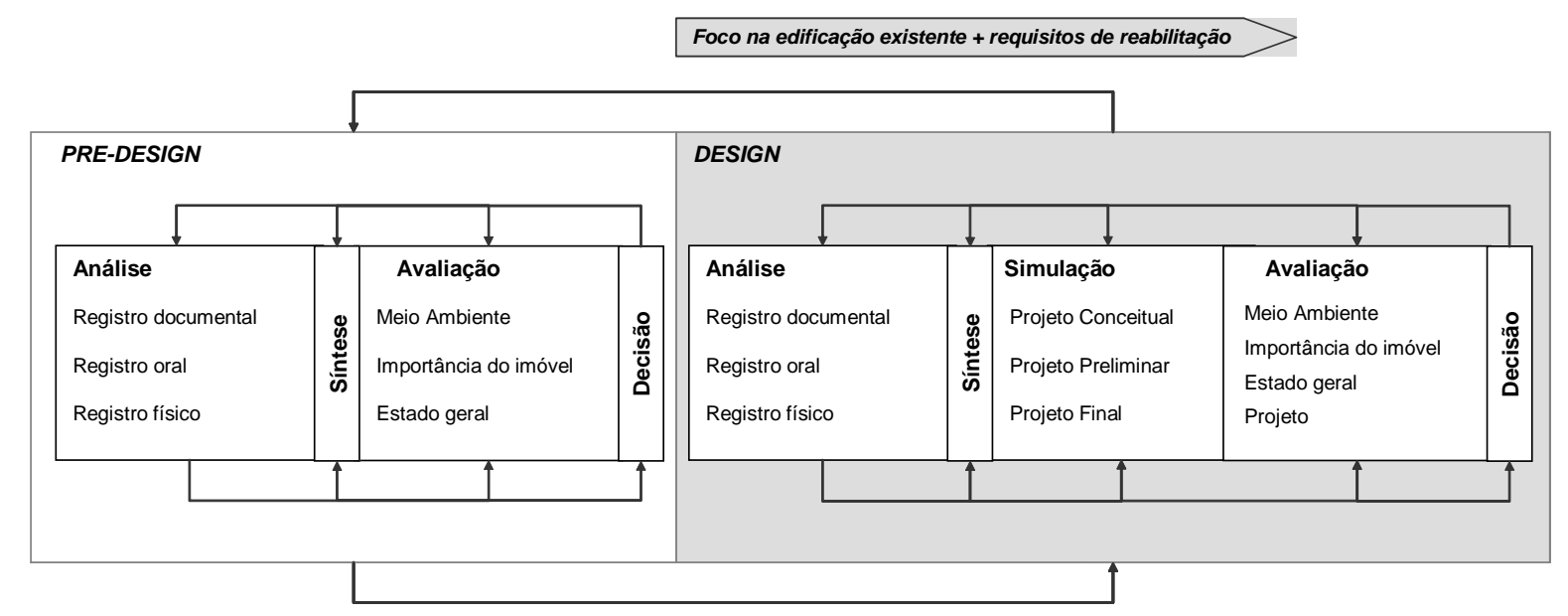

Figura 17 - Modelo de processo de projeto para reabilitação (adaptado de Roders, 2006)

As análises dos registros e as sínteses das informações mais importantes do ponto de vista da proposta de reabilitação são confrontadas com aquelas coletadas no estágio de pre-design. Principalmente nos empreendimentos onde haverá mudança de uso, é importante coletar, registrar e sintetizar todas as informações e requisitos aplicáveis à nova função do edifício. 
Esses novos dados, confrontados com aqueles sintetizados no estágio de predesign, proporcionarão às equipes de projetos informações precisas e alinhadas sobre as potencialidades da construção existente e as necessidades para a reabilitação. Além disso, essas informações influenciarão diretamente a etapa de simulação e materialização das soluções de projeto nos três momentos: conceitual, preliminar e final.

Segundo Roders (2006) é comum a etapa de projeto preliminar ser desenvolvida durante a etapa de análise, devido à necessidade de otimizar o tempo de desenvolvimento. Entretanto, a autora alerta que as equipes de projeto podem incorrer no erro de misturar informações precisas com suposições pessoais, e acabarem desvirtuando a etapa que deveria ser técnica e imparcial.

A etapa denominada "projeto final" é o registro conclusivo das alternativas selecionadas na etapa de "projeto preliminar". Neste momento, deverá ser apresentada pelo menos uma solução de projeto para os problemas identificados nas etapas anteriores.

Após a conclusão do desenvolvimento dos projetos, é feita a avaliação das vantagens e desvantagens das soluções adotadas, novamente do ponto de vista de meio ambiente, da importância do imóvel, do estado geral da edificação e, agora, também, do projeto de reabilitação proposto. Durante a etapa de avaliação, será definido se as soluções apresentadas no projeto final devem ser apresentadas aos agentes envolvidos ou se devem ser novamente revisadas.

As decisões tomadas, assim como todo o processo de projeto serão registradas e farão parte dos documentos oficiais do empreendimento de reabilitação. Esta documentação facilitará as futuras intervenções e preservará a histórica da edificação (RODERS, 2006).

As relações entre os agentes envolvidos no empreendimento nas etapas de processo de projeto ficam mais evidentes no modelo adaptado para 
empreendimento de reabilitação, proposto inicialmente por Melhado (1994), ilustrado na Figura 18.

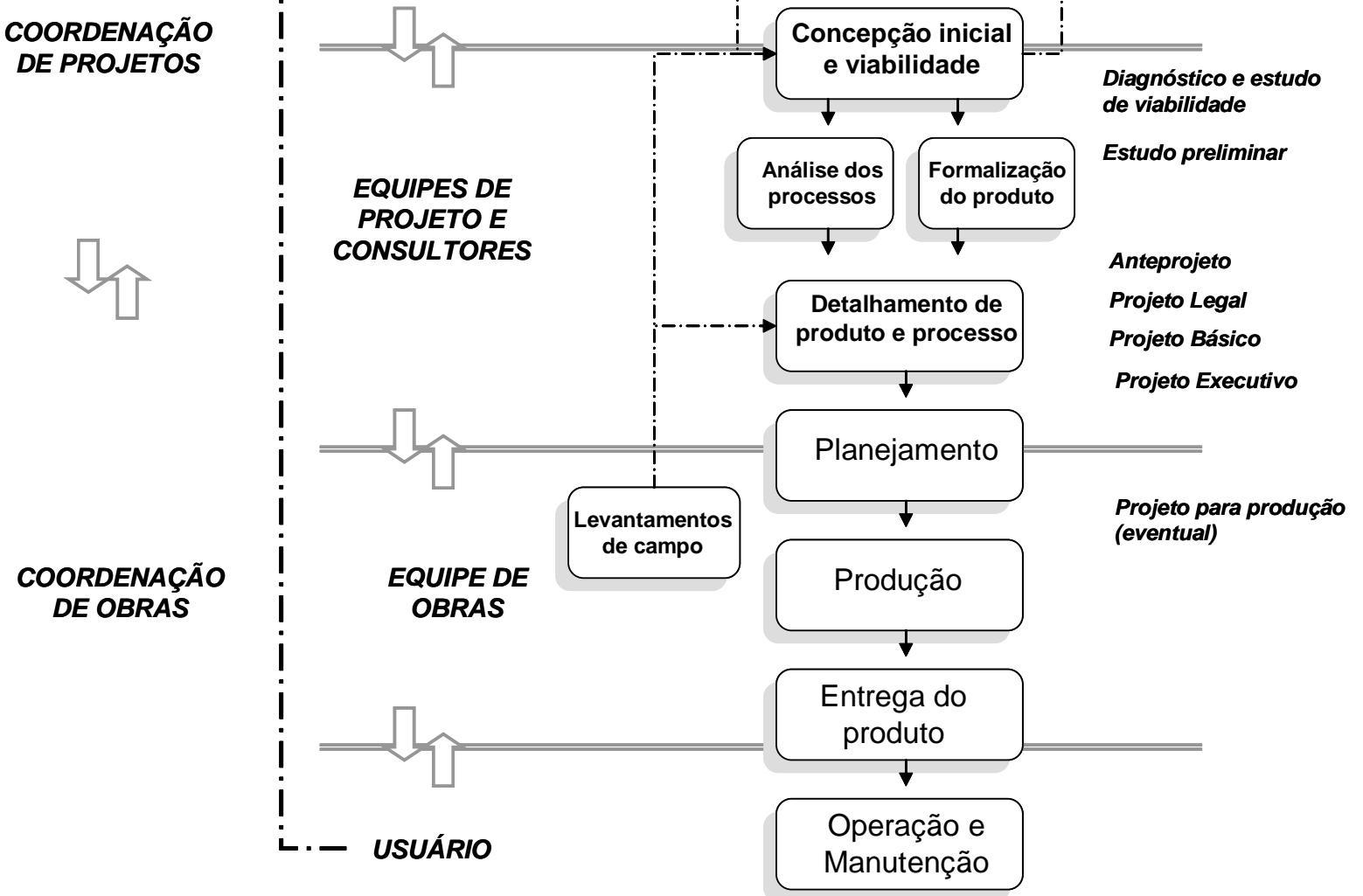

Figura 18 - Proposta para o processo de desenvolvimento do projeto com a ação de quatro participantes do empreendimento (adaptado de MELHADO, 1994)

Neste modelo, percebe-se a necessidade de haver uma relação próxima das equipes de projeto (e do coordenador de projetos) com o empreendedor e com a equipe de obras nas etapas preliminares. Esta característica é o principal diferencial do modelo quando aplicado a empreendimentos de reabilitação. Sempre que possível, as equipes de obra deverão subsidiar as decisões de projeto com dados coletados no campo.

Entretanto, nem sempre é possível contar com a equipe de obra desde o início do empreendimento, como no caso de obras públicas. Geralmente, a licitação para 
contratação da empresa construtora é realizada após a conclusão da etapa de projeto. Mas como o apoio de campo é muito importante para o desenvolvimento dos projetos, é recomendável que este papel seja desempenhado ou pela própria empresa de projetos ou, até mesmo, por um terceiro contratado para coletar dados no campo e dar suporte ao desenvolvimento dos projetos.

De forma geral, as etapas dos projetos de reabilitação possuem características específicas, diferente de projetos "novos" ou convencionais. Em certos casos, na etapa de idealização do produto, por exemplo, a definição do programa de necessidades pode conter características bem peculiares. Existem casos em que o empreendimento de reabilitação envolve diversos clientes finais, simultaneamente. Edifícios degradados que se enquadram nesse perfil são aqueles que se encontram ocupados (total ou parcialmente) ou possuem mais de um proprietário.

A gestão das demandas de projeto pelos diversos agentes envolvidos é uma atividade a mais a ser executada. A compilação das necessidades dos usuários precisa ser feita e a gestão das modificações, ao longo das atividades de projeto, deve ser notada.

A relação do empreendedor com o usuário, indicada na ilustração, compreendida em empreendimentos de reabilitação com o "foco no cliente", pode necessitar, ainda, do envolvimento de equipes de projeto, principalmente na etapa de detalhamento dos projetos. Essa relação entre empreendedor, equipes de projeto e usuários foi identificada no decorrer de um dos estudos de caso realizados durante esta pesquisa. Além disso, como será apresentado adiante, a interface entre todos esses agentes pode ser feita pelo coordenador de projetos.

A entrega de projetos para produção na etapa de detalhamento do produto pode ser eventualmente aplicada em empreendimentos de reabilitação. Entretanto, quando as variações dimensionais da estrutura existente são muito grandes e generalizadas, a elaboração dos projetos para produção pode ser comprometida. Será apresentado um estudo de caso, no qual a solução de projeto para produção de alvenarias foi a adoção de medidas médias dos elementos de estrutura dos pavimentos. 
Silva (2004) ressalta a importância da adoção de uma estratégia adequada, pelas empresas de projeto, no atendimento às necessidades atuais dos usuários dentro de um espaço concebido originalmente e com soluções que visavam o atendimento das necessidades da época da sua concepção.

O Projeto Reabilita (2007) identificou uma restrição ao processo de projeto de reabilitação no atendimento às normas vigentes, principalmente no que diz respeito às questões de segurança contra incêndio e acessibilidade. Constatou-se que os projetistas encontram dificuldade em adaptar as condições dos edifícios antigos às demandas de reservação de água para incêndio, devido ao tipo de fundação e às limitações estruturais dos edifícios; à criação de rotas de fuga e escadarias; ao atendimento das exigências de acessibilidade às áreas comuns e à cota de apartamentos prevista por lei em empreendimentos de habitação popular.

Se a definição das soluções projetuais, que atendam ao programa de necessidades apresentado, por um lado encontra dificuldades devido às limitações impostas pela estrutura existente; por outro, pode ser utilizada como objeto piloto para testes dessas soluções. Ou seja, durante o período de elaboração dos projetos, as diversas soluções podem ser simuladas em escala real na própria edificação existente. Segundo Manso (2006), deve-se considerar a verificação dos protótipos na obra como validação parcial do projeto, a fim de "proceder eventuais ajustes no projeto, melhorando o produto final".

Essa aplicação se estende para todas as disciplinas de projeto. Está se tornando cada vez mais comum a construção de apartamentos-modelo no estande de vendas de empreendimentos "novos". A mesma prática pode ser feita (desde que o imóvel se encontre desocupado) em empreendimentos de reabilitação, mas com um diferencial técnico-comercial. Nesses casos, pode-se experimentar a aplicação das soluções de projeto não apenas em escala real, mas principalmente no local final de utilização: o próprio imóvel degradado.

Identifica-se aí outro aspecto da relação entre a estrutura existente e o processo de projeto. O acesso ao corpo construído pode contribuir para os testes e, por conseqüência, à melhor adoção das soluções de projeto. Essa exploração pode ser 
feita de diversas maneiras, tais como: visitas, medições, registros fotográficos, filmagens, monitoramentos, simulações de soluções de projeto em escala real, prospecções detalhadas etc. O conceito de "projetar" ou "antever" a solução é modificado uma vez que se abre a possibilidade de se construir a solução no local já edificado.

Roders (2006) lembra que nesse processo o projetista pode retornar com a solução e incrementá-la, quantas vezes julgar necessário, até que se sinta satisfeito com o produto final do projeto. Atrelado à eventual possibilidade de se reproduzirem as soluções de projeto na edificação existente em escala real, o projetista pode redesenhá-las até entender que a melhor solução foi alcançada.

Uma vez que a concepção do produto foi feita e a viabilidade técnico-comercial foi confirmada, tem-se o estudo preliminar da reabilitação do empreendimento. Nesse momento, já devem estar envolvidos no empreendimento pelo menos os principais integrantes da equipe de projetos de reabilitação:

$>$ consultores de fundação;

$>$ consultores de estruturas;

$>$ projetista de arquitetura;

$>$ consultores de sistemas prediais;

$>$ consultores de sistema de transporte vertical (elevadores);

Após realizada a consulta aos órgãos públicos de aprovação e verificado o escopo necessário de adequação das construções, definem-se as técnicas construtivas mais apropriadas para o projeto.

A reabilitação de edifícios no Brasil convive com a carência de materiais e sistemas construtivos específicos. Entretanto, há um leque razoável de alternativas desenvolvidas para empreendimentos "novos" ou convencionais, que podem ser aplicados perfeitamente nas edificações reabilitadas. Dentre elas, segundo Barrientos (2004), destacam-se:

- blocos de concreto celular para novos painéis de vedação internos; 
- sistema de divisórias leves tipo drywall de gesso acartonado ou contraplacado;

- sistema de alimentação de água quente e fria flexível, tipo sistema PEX;

- shafts visitáveis localizadas nos sanitários com misturadores e chuveiro acoplados nas carenagens;

- fachadas ventiladas;

- forros metálicos, de madeira, gesso ou PVC;

- cabeamento estruturado;

- pisos: elevado e acústico etc.

O Projeto Reabilita (2007) complementa:

- sistema de medição individualizada de consumo de água em edifícios;

- PIP - Paredes Integradas Pré-montadas para aplicação em "paredes hidráulicas";

- módulos ou núcleos hidro-sanitários.

Todas essas soluções, segundo o Projeto Reabilita (2007), estão amplamente difundidas em países europeus e nos Estados Unidos da América e, parte delas, já está disseminada em obras "novas" nacionais e poderiam ser utilizadas em empreendimentos de reabilitação com mais freqüência. Os equipamentos de apoio às obras e sistemas do tipo "banheiro pronto" (Figura 19) são facilidades utilizadas em empreendimentos de reabilitação nesses países.
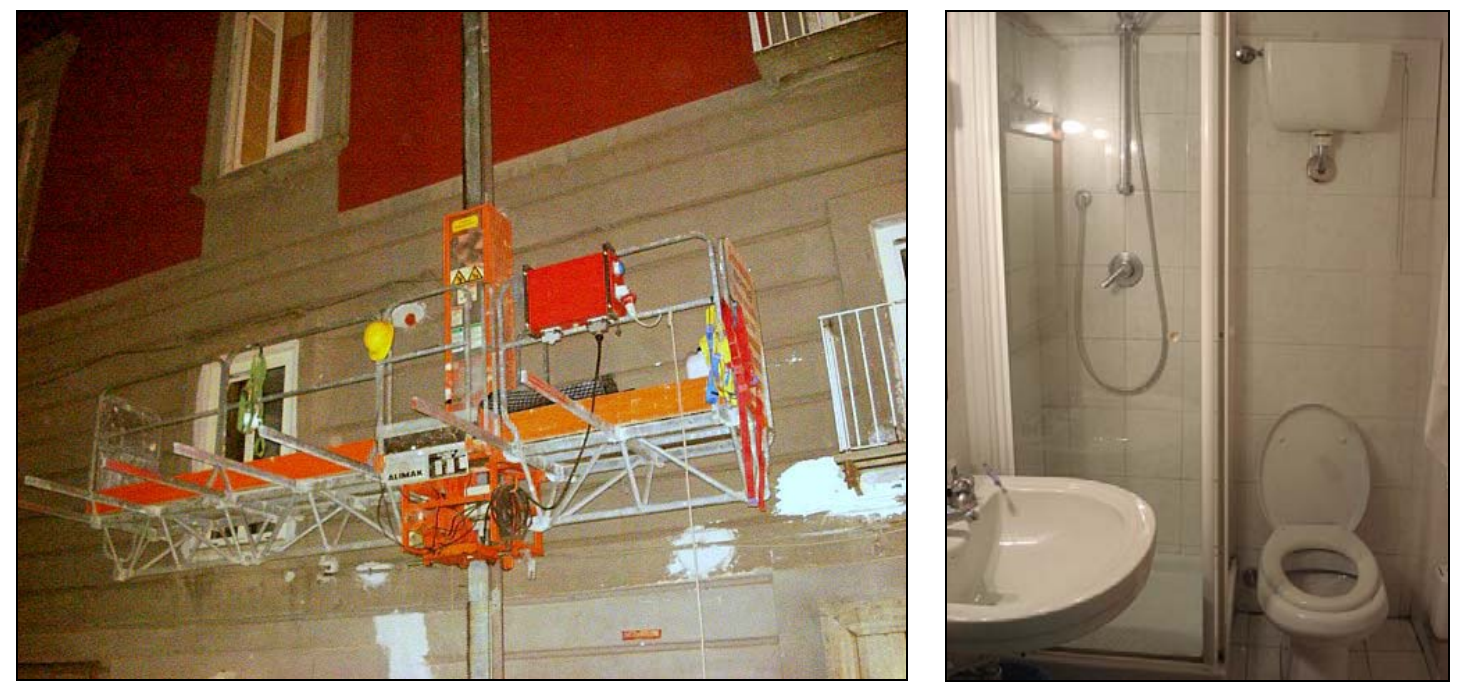

Figura 19 - Balancim elétrico instalado na fachada de edifício, na cidade de Nápoles, Itália (esq.) e "kit sanitário" na cidade de Florença, Itália (dir.) - arquivo do autor 
Após a formalização do produto, a etapa de detalhamento dos projetos apresenta características específicas nos empreendimentos de reabilitação.

Mais uma vez, o nível de detalhamento das atividades de prospecção, quando do início do empreendimento, se mostra importante. Quanto maior for a precisão e o detalhamento dessas informações, maior segurança terá o projetista para desenvolver o detalhamento dos projetos.

Como a variabilidade dimensional, encontrada no campo, geralmente é grande, tolerando variações em praticamente todos os ambientes de todos os pavimentos da construção, o trabalho de detalhamento dos projetos necessita de uma estratégia objetiva para encaminhar as informações à obra. As variações dimensionais encontradas nos edifícios degradados são muitas vezes significativas. Será apresentado um estudo de caso em que o desaprumo de um pilar variou até $14 \mathrm{~cm}$ ao longo dos pavimentos. Isso significou a necessidade de adequação dos projetos em todos os andares afetados.

Quando o empreendimento conta com uma equipe de apoio in loco para atender as demandas de projeto, as informações, que não foram coletadas nas etapas de diagnóstico e estudo de viabilidade, podem ser encaminhadas às equipes de projeto para complementação dos dados e estudos de alternativas.

Essa interlocução entre equipe de obra e projetistas deve ser conduzida pelo coordenador de projetos. O coordenador, cujo papel no empreendimento de reabilitação será estudado a seguir, deve atuar em contato direto com a obra e as equipes de projeto, além de ser responsável pela interface da equipe de projetos com o empreendedor e os demais agentes envolvidos no empreendimento.

Segundo Barrientos (2004), a gestão de projetos de um empreendimento de reabilitação deve conter:

i. realização de todas as inspeções e ensaios tecnológicos necessários;

ii. localização dos documentos técnicos; 
iii. auditoria nos projetos para verificação de cálculos, especificações, dimensionamentos e atendimento às normas vigentes da época;

iv. disponibilidade de equipe de campo para realização de todo tipo de levantamento no local, prestando apoio direto às equipes de projeto;

v. mapeamento completo da realidade dimensional das estruturas e instalações existentes;

vi. identificação, mapeamento e monitoramento completo das patologias encontradas na edificação;

vii. $\quad$ equipe de projetistas dedicada e envolvida com o empreendimento;

viii. regime de contratação dos projetistas e da coordenação de projetos compatível com a demanda do empreendimento.

Uma vez que essas condições são atendidas, o detalhamento dos projetos pode ser realizado de maneira satisfatória. $O$ que se observa, em determinados empreendimentos de reabilitação, é que a etapa de detalhamento não é realizada a contento. Em empreendimentos nos quais a qualidade das informações de campo não é satisfatória, as equipes de projeto não se sentem seguras para detalhar os projetos de maneira que atendam às inúmeras especificidades da construção existente e, então, encaminham para as equipes de obra elementos gráficos que não representam a realidade. Dessa forma, a tomada de decisão é transferida para o campo.

Nos casos em que as equipes de campo são bem estruturadas, possuem experiência, competência técnica e tempo suficiente para estudar e identificar a melhor solução, as soluções definidas em campo são acertadas. Caso contrário, corre-se o risco de os projetos serem colocados em segundo plano e serem tomadas soluções improvisadas definidas no canteiro de obras.

A participação de especialistas na etapa de diagnóstico pode ser importante para o entendimento da complexidade da intervenção. Essa consultoria pode ser dada por empresas fornecedoras de soluções de revestimento de fachadas, sistemas prediais, elevadores, calculista estrutural etc. Após a emissão do parecer final do diagnóstico e a elaboração dos projetos preliminares, a estimativa de custo do empreendimento pode ser dimensionada com maior precisão. Uma vez que os recursos financeiros e 
de prazo são aprovados pelos investidores, a programação da intervenção deve ser detalhada. A elaboração dos projetos detalhados se inicia juntamente com a contratação de fornecedores e, assim, se iniciam as obras de reabilitação.

\subsection{A OBRA DE REABILITAÇÃO DE EDIFÍCIOS}

Segundo Fontenelle (2002), a dissociação entre a atividade de projetar e a atividade de construir pode gerar reflexos negativos sobre a qualidade do produto final, além de redução dos resultados econômico-financeiros na atividade de empreender.

Freitas e Souza (2003) lembram que, por melhor que seja a qualidade dos trabalhos realizados nas etapas de diagnóstico e projeto, na etapa de execução certamente serão identificadas interferências não previstas anteriormente. É comum que essas interferências exijam ajustes e adaptações cujas soluções precisam ser desenvolvidas no campo pela equipe de obra. Por isso, os autores destacam a importância de ser formada equipe de campo capaz de controlar a execução das obras sob o aspecto técnico, mas também financeiro.

Roders (2006) sustenta que é comum durante a etapa de execução das obras de reabilitação, entre um desmonte de parede ou pavimento, serem encontradas novas evidências que necessitem da intervenção direta das equipes de projeto. Segundo a autora, em certos casos é necessária a paralisação das obras até que sejam solucionados os problemas e, eventualmente, no caso de alterações importantes, o novo projeto seja reaprovado junto aos órgãos competentes.

Será apresentada no capítulo que trata dos estudos de caso, uma situação em que as prospecções de campo foram feitas, mas a análise de projetos originais não foi considerada na etapa de estudo de viabilidade. Se essa análise tivesse sido realizada, poderia ter sido identificada uma grave falha existente na concepção do projeto estrutural original. Embora a equipe de campo tenha detectado as nãoconformidades de execução da estrutura, não foi possível detectar que não havia sido considerada a ação do vento no dimensionamento da estrutura. 
Empreendimentos de reabilitação são passíveis dessas intercorrências. O cronograma de execução das obras está sujeito a impactos dessa natureza. Da mesma forma, o custo do empreendimento pode ser afetado quando a intervenção não programada precisa ser realizada (Figura 20).
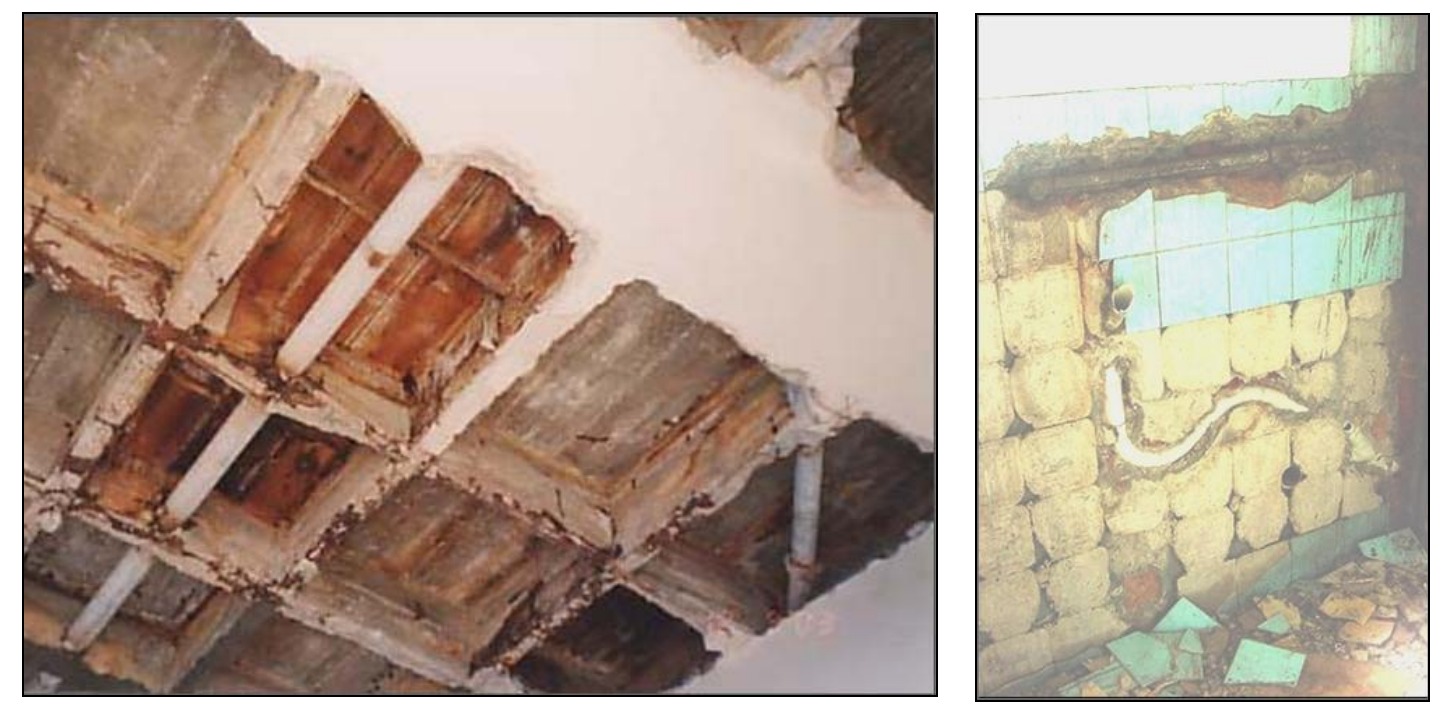

Figura 20 - À esquerda, vista inferior da laje: após início das obras de reabilitação se verificou a necessidade de executar a recuperação estrutural. À direita, sifonamento identificado após remoção do revestimento (arquivo do autor)

O equilíbrio contratual da empresa executante dos serviços também pode ser afetado, caso não tenham sido previstas cláusulas compensatórias.

O Projeto Reabilita (2007) classifica estas intercorrências como "elementos inesperados" que podem surgir durante a execução das obras como, por exemplo, a "presença de vigas ou pilares não constantes do projeto original, alvenaria estrutural em algumas vedações, impedindo remoções sem novos escoramentos, condições dos materiais piores do que o verificado na etapa de diagnóstico", entre outros.

Em virtude da existência desses elementos inesperados, deve ser gerada uma revisão do projeto que contemple as alterações e criado, ainda, um banco de dados para compilação das soluções de projeto adotadas para servir a empreendimentos futuros. 
Se por um lado, como apresentado, a etapa de projeto enfrenta os mais diferentes desafios e deve ser conduzida de forma específica, a execução da obra não é diferente. Além da carência de detalhamento dos projetos que muitas vezes ocorre, o fator mais importante é que o conhecimento para a execução de obras dessa natureza ainda está sendo consolidado entre as empresas construtoras.

Em certos casos, a carência de índices próprios e históricos de contratos já realizados (Figura 21) de referência para obras de reabilitação, leva as empresas construtoras a aplicarem coeficientes de majoração nos índices utilizados por elas em obras novas, como "margem de segurança" para os orçamentos.

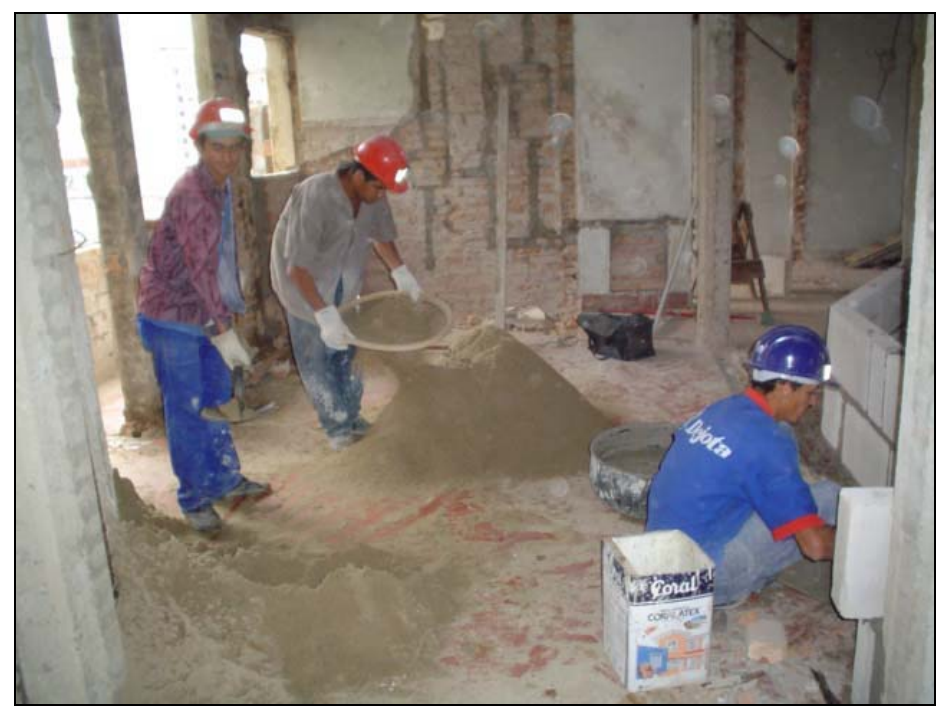

Figura 21 - Canteiro de obras: índices para elaboração de orçamento mais preciso (arquivo do autor)

As empresas têm adotado índices médios por metro quadrado para realizarem estimativas de custo de empreendimentos de reabilitação. Como esses índices de referência são adaptados e, portanto, não refletem as condições reais de execução, criam-se riscos de desequilíbrios financeiros e de prazo nos contratos de execução das obras (YOLLE, 2006).

Yolle (2006) apresenta uma contribuição nesse sentido ao apresentar uma proposta de estrutura padrão de custos de um empreendimento típico de reabilitação, voltado para habitação de interesse social, e a compara com a estrutura de custos de dois empreendimentos novos, ilustrada na Tabela 8. 
Tabela 8 - Comparação de estrutura de orçamento de empreendimento de reabilitação voltado para HIS e obras "novas" (adaptado de Yolle, 2006)

\begin{tabular}{lccc}
\hline \multicolumn{1}{c}{ Serviço } & $\begin{array}{c}\text { Peso diretriz } \\
\text { p/ HIS (\%) }\end{array}$ & $\begin{array}{c}\text { Obra Nova 1 } \\
\text { (\%) }\end{array}$ & $\begin{array}{c}\text { Obra Nova 2 } \\
\text { (\%) }\end{array}$ \\
\hline Instalações & $\mathbf{2 4 , 1 3}$ & 16,26 & 15,20 \\
\hline Pintura & $\mathbf{1 6 , 9 6}$ & 8,85 & 7,82 \\
\hline Alvenaria e revestimentos & 19,24 & $\mathbf{2 7 , 3 7}$ & $\mathbf{2 6 , 5 3}$ \\
\hline Esquadrias & 9,22 & 6,52 & 8,06 \\
\hline Piso & 8,29 & 3,92 & 5,49 \\
\hline Elevador & 6,28 & 6,91 & 5,56 \\
\hline Indiretos & 6,13 & 2,21 & 4,81 \\
\hline Fachada & 3,30 & 2,86 & 3,05 \\
\hline Telhado e impermeabilização & 3,30 & 2,36 & 2,24 \\
\hline Demolição & 3,15 & 0,00 & 0,00 \\
\hline Intervenção estrutural & 0,00 & $\mathbf{2 2 , 7 3}$ & $\mathbf{2 1 , 2 4}$ \\
\hline Total & $\mathbf{1 0 0 , 0 0}$ & $\mathbf{1 0 0 , 0 0}$ & $\mathbf{1 0 0 , 0 0}$ \\
\hline
\end{tabular}

A proposta, baseada em padrão típico de edifícios da cidade de São Paulo, visa servir de referência para orçamentos de obras de reabilitação e estudos de viabilidade de empreendimentos de HIS. Importante notar que o estudo não considera serviços de recuperação estrutural, que podem ser aplicados para um edifício com até dois elevadores e bom estado das fachadas. Considera, ainda, recuperação de caixilhos de aço e a instalação de forro de gesso apenas nos banheiros. Entretanto, nota-se que a utilização de índices para empreendimentos novos para orçamentação de empreendimentos de reabilitação pode causar distorções importantes.

Segundo dados coletados no universo da pesquisa do autor, o custo com pintura, em um empreendimento de reabilitação, pode representar aproximadamente 17\%, ao passo que os empreendimentos novos comparados chegam a aproximadamente $9 \%$.

Na proposta apresentada por Yolle (2006) a parcela "intervenção na estrutura" não foi considerada na composição de custos do empreendimento de reabilitação típico, o que, em determinados empreendimentos, pode representar uma parcela significativa do orçamento, como é o caso do empreendimento citado anteriormente, 
no qual foi necessária a intervenção estrutural para redimensionamento da estrutura contra a ação do vento.

Além dessa proposta, outras iniciativas estão sendo apresentadas para o mercado da reabilitação de edificações. A empresa PINI Engenharia de Custos desenvolveu uma ferramenta de apoio à elaboração de orçamentos chamada "Tabela de Custos para Manutenção e Reformas (TCMR) ${ }^{24 " . ~ A ~ b a s e ~ d e ~ d a d o s ~ f o r n e c i d a ~ a p r e s e n t a ~}$ taxas de consumo, índices de produtividade e custo, adaptados à realidade dos canteiros de obras de reabilitação e manutenção de edifícios e permite o ajuste da parcela de contingências das atividades. Essa iniciativa poderá orientar as empresas construtoras a dimensionarem adequadamente os seus orçamentos e a reduzirem o índice de incerteza de seus preços.

O Projeto Reabilita (2007) constata que a existência de parâmetros próprios para obras de reabilitação, em diversos aspectos, permitiria uma elaboração de projetos mais adequados e em um prazo mais reduzido, além da execução das obras com melhor qualidade, principalmente no tocante aos custos, que tendem a ser não confiáveis.

Mas, como Yolle (2006) afirma, o foco das empresas construtoras está voltado para o resultado final do empreendimento, não apenas do ponto de vista financeiro, mas também do ponto de vista da qualidade da execução. A seleção de subempreiteiros (Figura 22) e fornecedores deve ser objeto de planejamento por parte da empresa construtora. A pré-qualificação dos fornecedores nessa etapa é importante.

A constatação do Projeto Reabilita (2007), ao analisar diversos empreendimentos em três capitais brasileiras, é que a falta de qualificação técnica da mão-de-obra (em todos os níveis: execução da obra, projeto), desconhecimento e, por conseqüência, não utilização das ferramentas e técnicas de gestão pelas empresas, aumentam o custo de produção dos empreendimentos de reabilitação.

\footnotetext{
${ }^{24}$ Disponível em: http://construcao-engenhariaarquitetura.lojapini.com.br/pini/vitrines/detalhes/Detalhe4232.asp acesso em: 01.11.2007.
} 


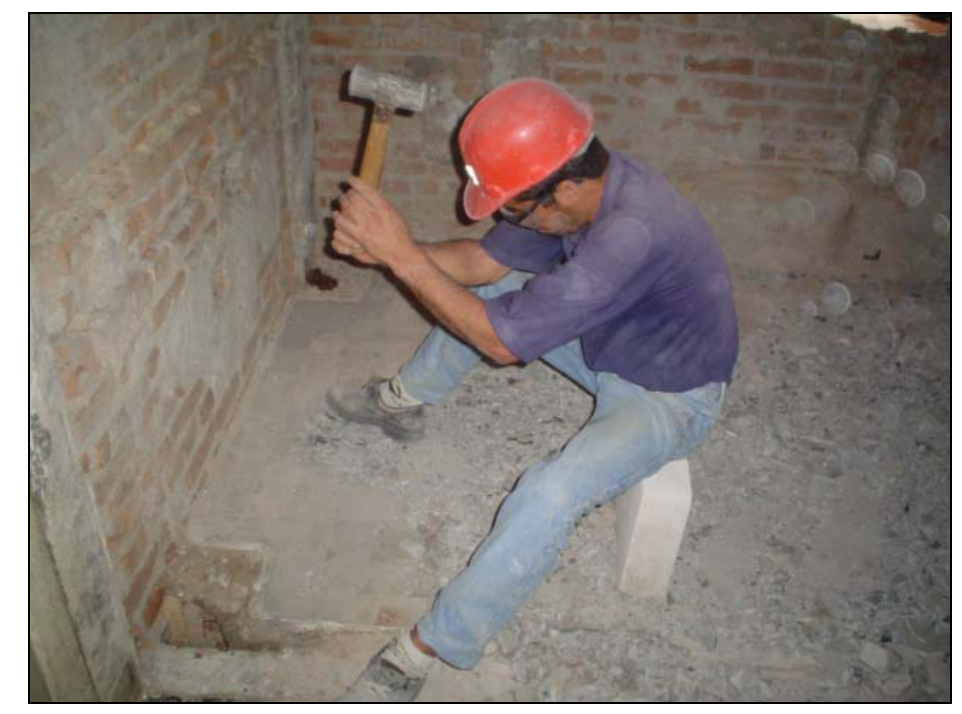

Figura 22 - Execução de serviços de reabilitação: pré-qualificação de fornecedores necessária (arquivo do autor)

Barrientos (2004) sugere cinco aspectos que devem ser considerados no processo de qualificação de empresas para contratação dos serviços, em um empreendimento de reabilitação. São eles:

- a diversidade de trabalhos que a empresa realiza;

- capacidade de adaptação da empresa a possíveis surpresas durante a realização dos serviços;

- referências de outras obras de mesmo porte, já executadas;

- experiência dos profissionais; e

- estabilidade financeira da empresa.

Appleton (2003) menciona que nos países europeus com tradição na reabilitação de edifícios, existem empresas especializadas nestes trabalhos, cujas características básicas são:

- empresas de pequeno porte;

- possuem grande mobilidade;

- mão-de-obra especializada em diferentes áreas;

- possuem equipamentos sofisticados e modernos; e

- corpo técnico com formação especializada e sensibilizado para este tipo de obra. 
Segundo Oliveira e Freitas (1998), os problemas encontrados na etapa de projetos estão fortemente relacionados à informação, em termos de disponibilidade, quantidade, qualidade, fluxo etc. Em empreendimentos de reabilitação a equipe de obras também cumpre o papel de "fornecedora" de informações para o desenvolvimento dos projetos.

Dependendo das características do empreendimento e da estratégia da empresa, pode ser formada uma equipe de campo que apoiará as etapas de diagnóstico, fornecendo elementos para o estudo de viabilidade e que, posteriormente, enviará dados para a elaboração dos projetos de reabilitação (Figura 23).
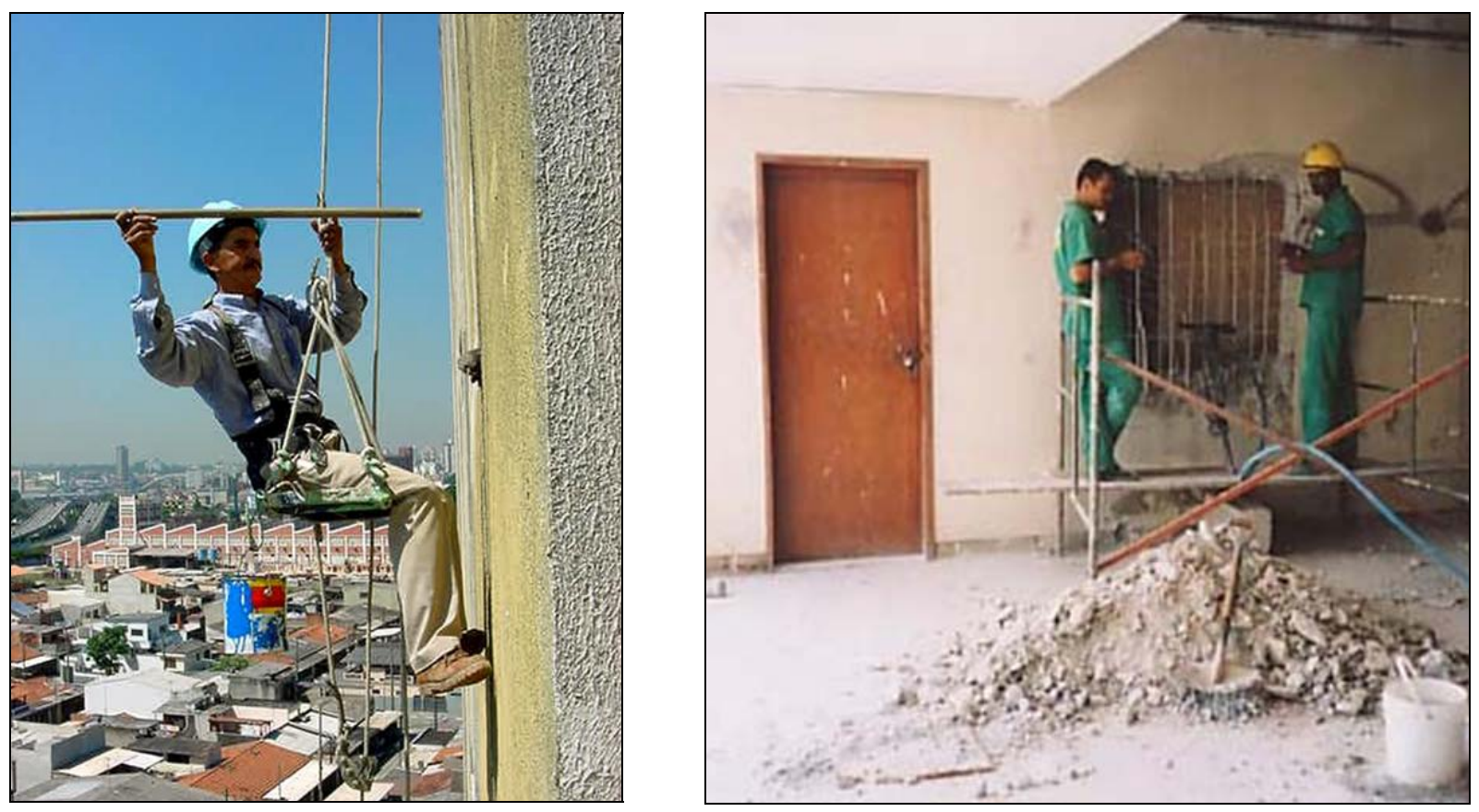

Figura 23 - À esquerda, mapeamento das fachadas na etapa de diagnóstico. À direita, abertura de parede para nova parada de elevador (arquivo do autor)

A participação do projetista no acompanhamento das obras deve ser intensa, segundo ressalta Freitas e Souza (2003). O projetista deve acompanhar de perto as decisões que são tomadas na obra e as alternativas estudadas em cada caso.

A importância do detalhamento de projetos, assim como em obras novas, está diretamente relacionada aos índices de retrabalho e ao custo total do 
empreendimento. Quanto melhor for o detalhamento dos projetos, melhor será o desempenho das obras e, por conseqüência, o resultado final do empreendimento.

Por essa razão, tanto a boa sintonia entre as equipes de projeto e obra, como a organização do fluxo de informações, são importantes. Segundo Oliveira e Freitas (1998), o alcance de projetos que descrevam "de forma completa e inequívoca a edificação", depende "intensamente da eficiência da comunicação".

Da mesma forma, a rapidez na tomada de decisão é importante na etapa de obra, uma vez que a existência de imprevistos é uma possibilidade real. Faz-se necessária a presença de um profissional responsável pelo diligenciamento, que tenha uma visão sistêmica do empreendimento, inclusive do ponto de vista econômicofinanceiro, e que tenha relacionamento próximo com o cliente.

Será apresentado estudo de caso em que a atuação da coordenação de projetos foi de fundamental importância para a agilidade da etapa de execução das obras. A presença do coordenador de projetos, durante a etapa de execução das obras de reabilitação, contribuiu para maior "eficiência da comunicação", mencionada por Oliveira e Freitas (1998) que, como consequência, contribuiu para a rapidez na tomada de decisão. 


\section{A COORDENAÇÃO DE PROJETOS EM EMPREENDIMENTOS DE REABILITAÇÃO DE EDIFÍCIOS}

Neste capítulo, será abordada a importância da coordenação de projetos nos empreendimentos de reabilitação de edifícios. Serão apresentadas as principais atividades do coordenador de projetos, assim como uma discussão sobre o perfil apropriado para o profissional e sobre os modelos de coordenação existentes e adequados para esses empreendimentos.

\subsection{COORDENAÇÃO DE PROJETOS NA REABILITAÇÃO DE EDIFÍCIOS}

Os empreendimentos de reabilitação de edifícios, assim como os demais empreendimentos na construção civil, contemplam atividades realizadas por diversos agentes que atuam de maneira seqüencial e/ou simultânea. Independentemente da organização das relações entre os agentes, as informações coletadas e produzidas nas diversas fases do empreendimento estão conectadas, ainda que em diferentes níveis de intensidade, e exercem impactos sobre as demais atividades. Essa relação entre agentes, atividades e informações é, muitas vezes, complexa e influencia diretamente os resultados do empreendimento. Wiazowski (2007) apresenta os três graus de intensidade de reabilitação em empreendimentos de reabilitação de edifícios comerciais, ilustrado na Tabela 9. 
Tabela 9 - Graus de intervenção de empreendimentos de reabilitação e a relação com a coordenação de projetos (adaptado de WIAZOWSKI, 2007)

\begin{tabular}{clc}
\hline Tipo & \multicolumn{1}{c}{ Descrição } & $\begin{array}{c}\text { Coordena } \\
\text { ção de } \\
\text { Projetos }\end{array}$ \\
\hline $\begin{array}{c}\text { Leve } \\
\text { ("light rehabilitation") }\end{array}$ & $\begin{array}{l}\text { Apenas poucos ítens do edifício sofrem algum tipo de } \\
\text { intervenção como, por exemplo, a instalação de um } \\
\text { sistema de ar condicionado etc. }\end{array}$ & Não \\
\hline $\begin{array}{c}\text { Média } \\
\text { ("substantial rehabilitation") }\end{array}$ & $\begin{array}{l}\text { Intervenção pouco mais complexa, com a introdução de } \\
\text { elevado, instalações hidráulicas, elevadores, instalações } \\
\text { elétricas, automação etc.) }\end{array}$ & Desejável \\
\hline Profunda & $\begin{array}{l}\text { Reabilitação completa do empreendimento. Nestes } \\
\text { casos apenas a estrutura do edifício é aproveitada. }\end{array}$ & Desejável \\
\hline ("gut rehabilitation") & & \\
\hline
\end{tabular}

Os empreendimentos de reabilitação do tipo "leve" não apresentam interdependência entre as atividades e, normalmente, possuem poucos agentes envolvidos $^{25}$. Nestes casos, o papel do coordenador de projetos pode não se justificar. Ao contrário, as reabilitações do tipo "média" e "profunda" requerem a participação de um agente integrador e de alguém que tenha uma visão geral do empreendimento, de todos os agentes envolvidos, das interferências entre as atividades que serão desenvolvidas etc.

Os estudos de caso que serão apresentados a seguir, incluem-se nos tipos "média" (estudo de caso 1 e 3) e "profunda" (estudo de caso 2). Neste último, a presença do coordenador de projetos foi importante, além de outros aspectos, para a integração dos agentes envolvidos.

Da etapa de concepção do produto à pós-entrega da obra é necessário que haja um agente que coordene as diversas fases do empreendimento, que consolide e distribua as informações e definições técnicas relativas a projetos, entre os demais agentes envolvidos. Essa atividade de suporte ao desenvolvimento do processo de

\footnotetext{
${ }^{25}$ Os principais agentes envolvidos em empreendimentos de reabilitação (fornecedores de materiais e sistemas, projetistas, construtores etc.) podem ser encontrados no ítem 2.2.
} 
projeto, voltada à integração dos requisitos e das decisões de projeto, é denominada "coordenação de projetos" 26.

Para Fontenelle (2002), coordenação de projetos compreende a "função de cunho técnico-gerencial que operacionaliza, em um dado empreendimento, a gestão do processo de projeto, buscando integrar sinergicamente as necessidades, conhecimentos e técnicas de todos os intervenientes envolvidos nessa fase, o que exige do coordenador de projeto grande domínio sobre o fluxo de informações (grifo nosso) necessário em cada etapa, alto poder decisório e de resolução de conflitos em nome do empreendedor".

Fabrício, Melhado e Grilo (2003) acrescentam que a coordenação de projetos deve garantir que as decisões tomadas nas diversas especialidades de projetos sejam "compatíveis, ampliando a qualidade e a construtibilidade dos projetos de edifícios". Melhado et al (2005) complementam que a coordenação de projetos, além de ser uma atividade de suporte ao desenvolvimento do processo de projeto, está voltada à integração dos requisitos e das decisões de projeto (grifo nosso).

Lana e Andery (2001) citam que as diversas etapas de um empreendimento são, muitas vezes, segmentadas e as soluções e definições "vão trocando de mãos, de maneira seqüencial". O coordenador de projetos deve promover a sinergia e a interação entre os agentes envolvidos, de modo a estabelecer uma visão holística do empreendimento.

A garantia da qualidade dos projetos, a interlocução entre as áreas de projetos e obras, o atendimento ao cronograma do empreendimento etc., são atividades que não dependem apenas de um agente, mas são fruto da relação entre dois ou mais agentes, que acontecem em momentos diferentes dentro do processo de projeto. Os resultados dessas atividades podem ser maximizados quando a coordenação de projetos é centralizada em um profissional ou em uma equipe de coordenação.

\footnotetext{
${ }^{26}$ Manual de Escopo de Serviços para Coordenação de Projetos - Indústria Imobiliária (versão 1.1). AGESC. Disponível em: http://www.manuaisdeescopo.com.br/Main.php?do=Inicial. Acesso em 17.11.2007.
} 
A "visão holística" mencionada por Lana e Andery (2001) é facilitada quando o coordenador de projetos participa de todas as etapas do empreendimento. Dessa forma, além de proporcionar a retroalimentação das etapas de projeto com as informações coletadas na pós-entrega da obra, permite ao coordenador o entendimento das necessidades do empreendimento como um todo e o capacita para as tomadas de decisão, com impactos positivos nas atividades de todos os agentes envolvidos.

Manso (2006) ressalta que o processo de gestão e coordenação de projetos não se encerra quando do término do desenvolvimento dos projetos, mas se estende durante todo o ciclo de construção do empreendimento, finalizando-se após a avaliação pós-ocupação, quando as lições aprendidas devem ser documentadas, retroalimentando todo o sistema.

O autor destaca ainda a importância do coordenador de projetos na etapa de execução das obras, uma vez que seria o responsável pela apresentação formal do projeto à equipe de produção, das premissas adotadas no seu desenvolvimento, dos principais cuidados a serem tomados durante a execução e demais informações relevantes, "passando também pelo acompanhamento de sua utilização (grifo nosso), quando, tanto o coordenador, quanto os projetistas devem dar suporte à equipe de produção no esclarecimento de dúvidas, correções de eventuais erros ou complementações".

Especialmente em reabilitação de edifícios, esta última etapa descrita por Manso será crucial para o bom andamento das obras. O "acompanhamento da utilização do projeto", no caso de empreendimentos de reabilitação, torna-se uma etapa em que há troca de informações entre a coordenação de obras e a coordenação de projetos, de maneira que as demandas que surgirem ao longo da etapa de execução das obras sejam atendidas com o menor impacto possível no cronograma.

Manso (2006) relaciona uma lista de possíveis problemas que podem ocorrer em um empreendimento, quando há uma coordenação de projetos deficiente, ou quando não há coordenação de projetos, frutos de uma falta de visão do todo, pelas equipes 
ou pelo fato de não conhecerem as limitações técnicas da empresa construtora que executará as obras:

- não-atendimento às necessidades do cliente em função de incorreções nos dados de entrada (etapa de diagnóstico), prejudicando sua comercialização e conseqüentemente seu resultado financeiro;

- inviabilização de soluções de projeto em função da falta de dados de entrada ou não-participação de todas as especialidades no início do processo;

- divergências entre o produto projetado e o produto comercializado por falta de comunicação com a incorporadora;

- atrasos no cronograma em função de deficiências na capacidade de planejamento e gestão;

- incompatibilidades entre projetos, em função de deficiências na comunicação entre os membros da equipe;

- explicitação gráfica deficiente em função do não-conhecimento das reais necessidades da equipe de produção;

- opção por sistemas construtivos inadequados ao perfil da obra ou da construtora por falta de conhecimento da cultura da construtora ou visão global do empreendimento;

- não-garantia de melhorias contínuas e/ou não-garantia da manutenção das melhorias alcançadas em função da falta de retroalimentação do processo; e

- problemas de construtibilidade em função do distanciamento entre o projeto e o processo construtivo, entre outros.

\subsection{ATIVIDADES DE COORDENAÇÃO DE PROJETOS}

$\mathrm{Na}$ estrutura tradicional de empreendimentos de construção civil, aqui chamados de "novos", a coordenação de projetos desempenha um papel notadamente importante, pois é responsável, dentre outras coisas, por atuar diretamente nos entraves existentes nas interfaces de projeto, entre as diversas disciplinas, e com a etapa de execução da obra. 
No entanto, se em empreendimentos "novos" ou convencionais a atuação desse agente catalisador de informações e gestor de conflitos, entre as diversas atividades, é importante para um processo de projeto adequado e eficiente, em empreendimentos de reabilitação seu papel é ainda mais importante.

O papel de "integrador" de equipes (LANA e ANDERY, 2001) é fundamental em empreendimentos de reabilitação. pois o nível de complexidade das relações entre as equipes é maior nesse tipo de empreendimento (

Figura 24). Além disso, a ocorrência de imprevistos no momento da execução das obras é mais elevada em virtude dos "elementos-surpresa", bastante comuns durante a etapa de execução das obras.

\section{EMPREENDEDOR}
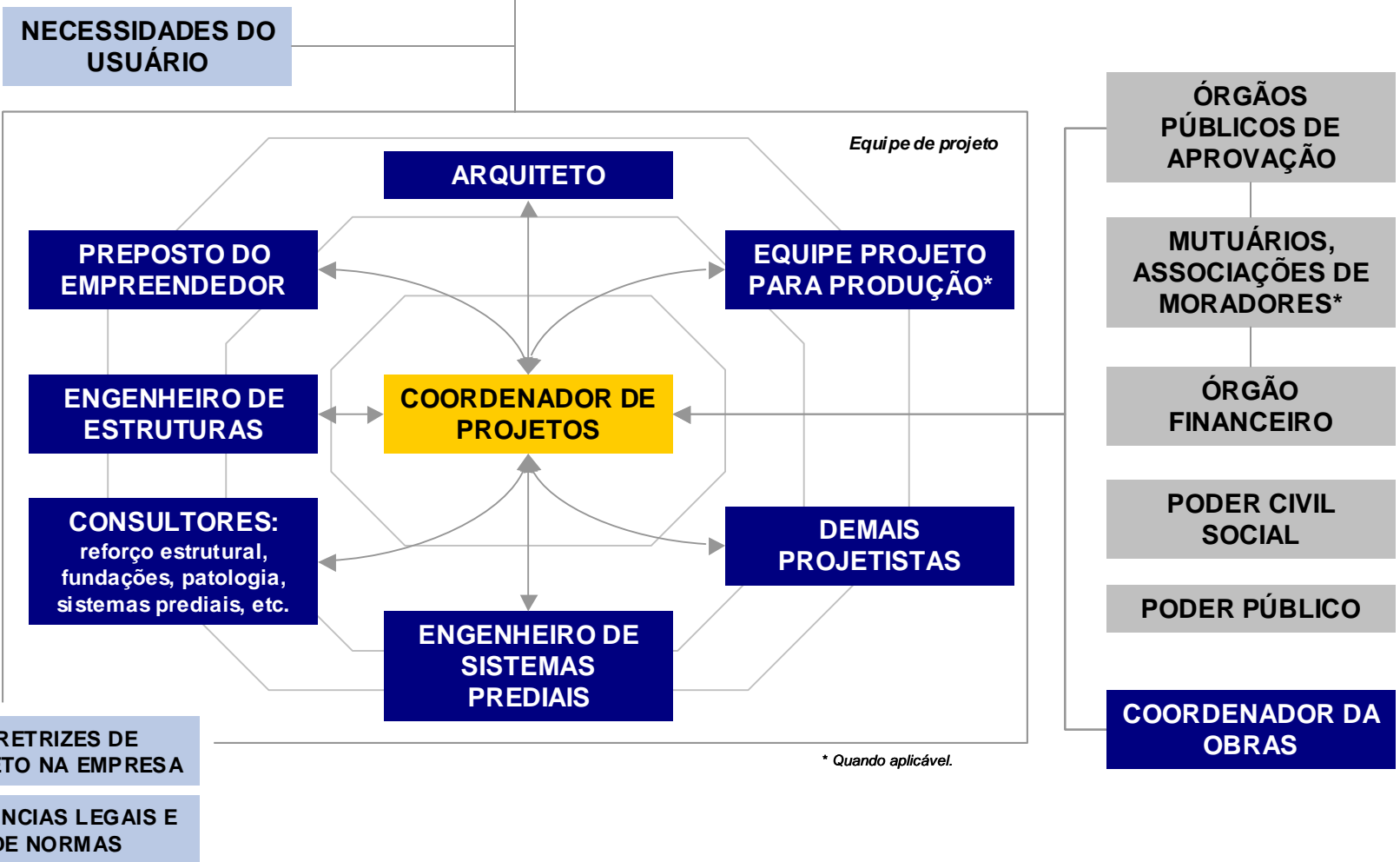
Figura 24 - Proposta de estruturação de equipe multidisciplinar envolvida no desenvolvimento do projeto (adaptado de MELHADO, 1994)

Isso ocorre porque empreendimentos de reabilitação geralmente apresentam uma ocorrência maior de entraves na etapa de execução das obras, em virtude de elementos não identificados nas etapas de diagnóstico. Além das diversidades usuais encontradas nos trabalhos multidisciplinares, a interdependência entre as áreas de projeto e obra exige coordenações eficientes em ambas as áreas. Dessa forma, em empreendimentos de reabilitação, o papel da coordenação de projetos é fundamental, uma vez que a sistemática das atividades das equipes de projeto e o desenho do fluxo da informação é dinâmico ao longo da execução do empreendimento.

Segundo Manso (2006), cabe ao coordenador de projetos o gerenciamento e o monitoramento do fluxo das informações. A comunicação, que pode ser "oral e escrita, falada e ouvida, interna e externa, formal e informal, vertical e horizontal", é um dos aspectos mais importantes para o sucesso do empreendimento.

Assim como nas demais etapas do processo de projeto, a metodologia de coordenação de projetos aplicada a empreendimentos "novos" ou convencionais precisa ser revisada e adaptada à realidade do empreendimento de reabilitação. A aplicação de métodos existentes poderá não se mostrar eficiente, uma vez que toda a estrutura do empreendimento e os fluxos internos são diferentes.

Fabricio, Melhado e Grilo (2003) defendem a autonomia do coordenador de projetos para a decisão das soluções de projeto que devem ou não ser tomadas. Segundo os autores, para que haja essa autonomia o coordenador deve ter um papel efetivo na contratação dos projetistas que comporão as equipes de projeto.

No modelo de gestão em que não há o papel do coordenador de projetos, as atividades de coordenação acabam sendo executadas pelos profissionais, de maneira conjunta com as demais atividades. Tradicionalmente, segundo Fabricio, Melhado e Grilo (2003), nesses casos o projetista de arquitetura assume o papel de 
coordenador e procura dividir seus esforços de desenvolvimento de projetos com as atividades de coordenação.

Segundo Medeiros (2006), a atividade de coordenação demanda do profissional imparcialidade e isenção nas definições. Na prática, se o coordenador também é responsável por uma disciplina de projetos, sua imparcialidade fica comprometida, pois ele estará submetido às diretrizes estipuladas por ele mesmo, e ainda terá a responsabilidade de fazê-las serem cumpridas pelos demais agentes envolvidos. Ou seja, se eventualmente ele não cumprir suas responsabilidades no papel de projetista, ele terá menos autoridade para cobrar o mesmo das demais equipes de projeto.

Em situações nas quais o papel do coordenador de projetos não é definido, os eventuais conflitos de interesses existentes entre os diversos agentes envolvidos no empreendimento, podem levar um tempo maior para serem resolvidos e, ainda assim, as soluções adotadas podem não obrigatoriamente atender aos interesses gerais do projeto.

No decorrer do desenvolvimento dos projetos, os pontos críticos das etapas são percebidos pelos projetistas das diversas especialidades. Cada projetista se dedica a desenvolver a sua especialidade e a buscar informações que subsidiem o desenvolvimento daquela determinada disciplina. A visão holística (LANA e ANDERY, 2001) do empreendimento mais uma vez se mostra importante para o processo de projeto.

As atividades de coordenação de projetos se iniciam desde as primeiras etapas do empreendimento. Melhado et al (2005), ao apresentarem as principais tarefas a serem cumpridas pela coordenação de projetos, afirmam que parte delas está relacionada à organização e ao planejamento do processo de projeto, o que chamam de "planejamento do processo de projeto" e, a outra parte, à gestão e coordenação de soluções de projeto desenvolvidas, chamada de "gestão do processo de projeto". 
$\mathrm{Na}$ etapa de planejamento do processo de projet, o coordenador tem condições de antever os entraves do processo e coordenar as ações entre todos os projetistas envolvidos.

Segundo Melhado et al (2005), são atividades do coordenador relativas ao planejamento do processo de projeto:

- estabelecer os objetivos e parâmetros a serem seguidos no desenvolvimento dos projetos;

- definir os escopos de projeto, segundo especialidades e etapas de projeto;

- planejar os custos de desenvolvimento dos projetos;

- planejar as etapas e prazos de desenvolvimento das diversas etapas, no todo e por especialidades de projeto, para estabelecerem-se cronogramas.

Ainda segundo os autores, são atividades do coordenador de projetos, quanto à gestão do processo de projeto:

- controlar e adequar os prazos planejados para desenvolvimento das diversas etapas e especialidades de projeto - gestão de prazos;

- controlar os custos de desenvolvimento dos projetos em relação ao planejado;

- fomentar e garantir a qualidade das soluções técnicas adotadas nos projetos;

- validar (ou fazer validar pelo empreendedor) as etapas de desenvolvimento e os projetos dela resultantes;

- fomentar a comunicação entre os participantes do empreendimento, coordenar as interfaces e garantir a compatibilidade entre as soluções das múltiplas especialidades envolvidas no empreendimento; e

- integrar as soluções de projeto com as fases subseqüentes do empreendimento, particularmente na interface com a execução da obra.

O detalhamento das atividades do coordenador, nas diferentes etapas do processo de projeto, é apresentado na Tabela 10 e será comentada por etapas. 
Tabela 10 - Atividades de coordenação nas etapas de projeto (adaptado de Melhado et al, 2005) continua

\begin{tabular}{|c|c|}
\hline Etapa de projeto & Atividades de coordenação \\
\hline $\begin{array}{l}\text { Etapas } \\
\text { preliminares }\end{array}$ & $\begin{array}{l}\text { - } \quad \text { Formulação conjunta com o empreendedor do Programa de Necessidades (briefing); } \\
\text { - } \quad \text { Levantamento das restrições legais de uso e ocupação da edificação em estudo; } \\
\text { - } \quad \text { Identificação das necessidades de adequação do imóvel às leis e normas vigentes; } \\
\text { - } \quad \text { Assessoria ao empreendedor para a aquisição do imóvel; } \\
\text { - } \quad \text { Identificação das demandas e assessoria na contratação de consultorias especializadas; } \\
\text { - } \quad \text { Coordenação dos trabalhos de diagnóstico do imóvel (incluindo análise de projetos originais); } \\
\text { - } \quad \text { Estimativa de recursos necessários ao desenvolvimento do projeto; } \\
\text { - } \quad \text { Análise da viabilidade financeira de um produto em um dado imóvel; } \\
\text { - } \quad \text { Assessoria jurídica, fiscal e tributária para o empreendimento; } \\
\text { - } \quad \text { Formulação das diretrizes tecnológicas do empreendimento; } \\
\text { - } \quad \text { Identificação e planejamento das etapas de desenvolvimento dos projetos; } \\
\text { - } \quad \text { Identificação e análise crítica das interfaces de projeto a serem solucionadas; } \\
\text { - } \quad \text { Validação de produtos e liberação para início das etapas subseqüentes; } \\
\text { - } \quad \text { Aprovação de memoriais descritivos do produto, maquetes, apto modelo, plantas e estande de vendas; } \\
\text { - } \quad \text { Análise das propostas de prestação de serviço e assessoria para contratação de projetistas; } \\
\text { - } \quad \text { Análise dos custos e de alternativas tecnológicas para execução (“eventual"); } \\
\text { - } \quad \text { Consulta aos órgãos públicos competentes para efeito de aprovações legais do projeto ("eventual”); } \\
\text { - } \quad \text { Assessoria ao empreendedor para contratação de construtora ("eventual"). } \\
\text { necessários segundo a natureza do produto a projetar; }\end{array}$ \\
\hline
\end{tabular}

A participação do coordenador de projetos desde as primeiras etapas do empreendimento é importante para garantir que as informações relevantes para as etapas de projeto subseqüentes sejam obtidas logo no início. Um exemplo disso, em empreendimentos de reabilitação, são as exigências legais de atualização do imóvel às leis e normas vigentes. As informações coletadas nessa etapa serão fundamentais para compor a análise de viabilidade. Eventualmente, o custo para atualização do imóvel às exigências legais vigentes pode conduzir à inviabilidade técnico-econômica do empreendimento. 
Nessa etapa, vale a pena destacar que a coordenação de projetos deve contribuir para que os elementos coletados nas atividades de diagnóstico do imóvel dêem subsídios para a análise de viabilidade do empreendimento. Eventualmente, o coordenador de projetos será o responsável pela coordenação das equipes de campo. Em empreendimentos públicos, onde tradicionalmente a execução das obras é contratada posteriormente à elaboração dos projetos, a empresa construtora não participa da etapa de viabilidade.

Nessa situação, as equipes de levantamento de campo podem ser contratadas pelas empresas projetistas ou diretamente pelo órgão público para auxiliar na etapa de diagnóstico. O papel do coordenador de projetos, que pode ser exercido pelo corpo técnico do órgão público, por exemplo, passa a ser ainda mais importante para que as informações sejam transferidas de um agente ao outro ao longo das etapas do empreendimento.

O coordenador de projetos, além de promover que o fluxo das informações entre as equipes de projeto seja realizado da melhor forma possível, eventualmente poderá intermediar o fluxo de informações das equipes de projeto com as equipes de levantamento de dados no campo (

Tabela 11). Na elaboração dos projetos de reabilitação, parte dos dados de entrada são as restrições/oportunidades impostas pela estrutura existente. Portanto, as equipes de projeto dependem destas informações de campo para desenvolverem os projetos específicos.

Tabela 11 - Atividades de coordenação nas etapas de projeto (adaptado de Melhado et al, 2005) continuação

\begin{tabular}{ll}
\hline Etapa de projeto & \multicolumn{1}{c}{ Atividades de coordenação } \\
\hline & - Coordenação do fluxo de informações entre os agentes intervenientes para o desenvolvimento das \\
& partes do projeto, incluindo equipes de levantamento de dados no campo; \\
& - Controle do processo quanto ao tempo e demais recursos, incluindo as ações corretivas \\
necessárias; & - Organização, realização e registro de reuniões de coordenação de projetos; \\
& - Análise das soluções e do seu grau de satisfação frente ao Programa de Necessidades; \\
& - Avaliação dos indicadores de projeto; \\
& - Análise crítica e tomada de decisões sobre as necessidades de integração das soluções; \\
\hline
\end{tabular}




\begin{tabular}{ll}
\hline & Avaliação do desempenho dos projetistas contratados. \\
\hline & partes do projeto, incluindo equipes de levantamento de dados no campo; \\
& - Controle do processo quanto ao tempo e demais recursos, incluindo as ações corretivas \\
Detalhamento & necessárias; \\
& - Organização, realização e registro de reuniões de coordenação de projetos; \\
& - $\quad$ Validação de produtos de projeto e liberação para início das etapas subseqüentes; \\
& Avaliação do desempenho dos projetistas contratados.
\end{tabular}

$\left(^{\star}\right)$ O termo "eventual" significa, aqui, que a atividade poderá ser exercida por outro profissional ou área e, apenas eventualmente, será atribuída à coordenação.

A participação do coordenador de projetos, na etapa de planejamento e execução das obras de reabilitação (Tabela 12), será um agente importante para garantir que as soluções de projeto sejam tomadas quando forem identificadas novas interferências de projeto no canteiro de obras. Juntamente com o coordenador de obras, o coordenador de projetos garantirá que as interferências encontradas no canteiro, durante a execução das obras de reabilitação, sejam conhecidas e estudadas pelas equipes de projeto e que essa responsabilidade não seja delegada às equipes de obra.

Tabela 12 - Atividades de coordenação nas etapas de projeto (adaptado de Melhado et al, 2005) conclusão

\begin{tabular}{|c|c|}
\hline Etapa de projeto & Atividades de coordenação \\
\hline $\begin{array}{l}\text { Planejamento e } \\
\text { Execução da obra }\end{array}$ & $\begin{array}{l}\text { - } \quad \text { Acompanhamento e avaliação do uso dos projetos no canteiro de obras e seus eventuais ajustes; } \\
\text { - } \quad \text { Promover agilidade no processo de definição de soluções de projeto quando interferências não } \\
\text { previstas são identificadas; } \\
\text { - } \quad \text { Coordenação do fluxo de informações entre os agentes envolvidos; } \\
\text { - } \quad \text { Organização, realização e registro de reuniões de preparação da execução da obra ("eventual"). }\end{array}$ \\
\hline $\begin{array}{l}\text { Pós-entrega do } \\
\text { Empreendimento }\end{array}$ & $\begin{array}{l}\text { - } \quad \text { Avaliação pós-ocupação e adequação do edifício a parâmetros de desempenho e manutenção; } \\
\text { • } \quad \text { Organização, realização e registro de reuniões de avaliação e retroalimentação ("eventual"). }\end{array}$ \\
\hline
\end{tabular}

O coordenador deve iniciar suas atividades no empreendimento desde a escolha da edificação a reabilitar. Em empreendimentos de reabilitação, o empreendedor deve contar com o apoio técnico da coordenação de projetos para desenvolver o prédiagnóstico da edificação a reabilitar.

A participação do coordenador, desde as primeiras etapas do empreendimento, orientará as atividades de maneira que o fluxo do processo de projetos se inicie de maneira organizada, desde o princípio, e as informações produzidas ao longo das 
etapas sejam permeadas entre as equipes envolvidas. A consolidação das alternativas aventadas nas etapas de diagnóstico e o estudo de viabilidade do empreendimento, além da tomada de decisão de reabilitar, ou não, determinada edificação, será conduzida pelo coordenador de projetos.

Manso (2006) entende que a liderança do coordenador de projetos na gestão do desenvolvimento do projeto é primordial para garantir a qualidade no processo de projeto e, conseqüentemente, no produto pela integração dos diversos intervenientes.

Nascimento (2002) destaca que a coordenação precisa ser responsável pelo controle dos documentos e dados distribuídos à equipe, a fim de evitar retrabalhos. O autor enfatiza a importância do cuidado para que os integrantes da equipe não sejam sobrecarregados de dados, informações e documentos. O papel do coordenador é estar atento, acompanhar o desenvolvimento dos projetos e alimentar as diferentes disciplinas com as informações atualizadas necessárias para as diferentes etapas. O uso inadequado e o acúmulo excessivo de informações podem criar desarmonia nos processos ao longo do empreendimento.

\subsubsection{O perfil do coordenador de projetos}

A cultura das empresas quanto à gestão de seus empreendimentos tem passado por processos de mudança nos últimos anos. A coordenação de projetos já é realidade em muitas empresas incorporadoras/ construtoras na cidade de São Paulo.

O modelo de coordenação de projetos mais comum nos empreendimentos é aquele no qual o projetista de arquitetura exerce a função do coordenador de projetos. Pelo fato de, tradicionalmente, essa ser uma das primeiras disciplinas de projeto a iniciar suas atividades no empreendimento e pelo tipo de relacionamento que, muitas vezes, é cultivado entre o empreendedor e a empresa de projetos de arquitetura, somado ao fato de que essa disciplina é a principal fornecedora de dados para o 
início dos trabalhos das demais disciplinas de projeto, o arquiteto acaba concentrando em si mesmo as atividades de coordenação.

Melhado (2002), ao analisar o perfil do coordenador sob o ponto de vista de processos da coordenação de projetos, destaca a importância desse profissional ser uma pessoa que possua boa organização no trabalho, conceitos de administração e de gestão.

Para Manso (2006), o coordenador de projetos deve desenvolver as habilidades de liderança, caso não seja um líder nato. Segundo o autor, a atuação do coordenador de projetos está fortemente orientada para a liderança do processo e da equipe, pois "é quem estabelece limites e prioridades, guia, orienta, delega, motiva e encoraja, a fim de extrair o melhor das pessoas".

Thomaz (2001) destaca a importância da coordenação de projetos ser realizada por profissional com conhecimento e experiência adequados ao tipo de empreendimento que será executado. Além disso, deve contar com a confiança do empreendedor, ou da empresa construtora, e deve participar diretamente da escolha das empresas que farão parte da equipe de projetos. Segundo o autor, o profissional pode ser o autor do projeto de arquitetura, um profissional experiente da empresa construtora ou um consultor especialmente contratado para essa função.

Entretanto, dependendo das características do empreendimento, o projetista de arquitetura pode não se mostrar capaz de exercer simultaneamente todas as atividades de coordenação de projetos. Além das habilidades de gestão necessárias e experiência quanto à execução de obras, outros aspectos técnicos podem ser requeridos ao longo do empreendimento ${ }^{27}$ :

- sobre técnicas e processos de projeto pertinentes às várias disciplinas envolvidas (arquitetura, paisagismo, fundações, estruturas, sistemas prediais, fôrmas, vedações etc.);

\footnotetext{
${ }^{27}$ Manual de Escopo de Serviços para Coordenação de Projetos - Indústria Imobiliária (versão 1.1). AGESC. Disponível em: http://www.manuaisdeescopo.com.br/Main.php?do=Inicial. Acesso em 17.11.2007.
} 
- sobre normas técnicas, legislação federal, estadual ou municipal, códigos de construção e padrões das concessionárias locais de serviços públicos (água, esgoto, energia, telefone, gás, TV por assinatura etc.);

- sobre tecnologia construtiva em curso e inovações tecnológicas no segmento de edificações;

- sobre técnicas de planejamento, programação e controle de projetos;

- sobre informática e gestão de informação.

Há casos de reabilitação de edifícios em que há a necessidade de dedicação integral do profissional à função de coordenador de projetos, como será apresentado adiante nos resultados de um dos estudos de caso realizados.

Devido à falta de tempo para conciliar as atividades de desenvolvimento de projetos de arquitetura e coordenação de projetos, por vezes, as atividades de coordenação são penalizadas e simplificadas à "compatibilização de projetos". Essa atividade, que compreende a sobreposição dos elementos gráficos para a identificação de eventuais interferências entre projetos e a indicação de alternativas de solução, é parte das atividades de coordenação e não representam a sua totalidade.

Assim como os demais projetistas das diversas especialidades, os projetistas de arquitetura dedicam-se a desenvolver seus projetos e, exercer as atividades de coordenação torna-se, então, mais um desafio.

Thomaz (2001) apresenta as principais vantagens e desvantagens dos diferentes perfis de coordenação de projetos (

Tabela 13).

Tabela 13 - Características das diferentes modalidades de coordenação de projetos (adaptado de THOMAZ, 2001)

\begin{tabular}{|c|c|c|}
\hline Coordenador de projetos & Vantagens & Desvantagens \\
\hline $\begin{array}{l}\text { Arquiteto ou escritório de } \\
\text { arquitetura }\end{array}$ & $\begin{array}{l}\text { - visão sistêmica do projeto de reabilitação } \\
\text { - facilidade de detectar interferências entre } \\
\text { projetos e entre projeto e estrutura existente } \\
\text { - imparcialidade entre técnica e custos } \\
\text { - melhor interface com equipes de projeto }\end{array}$ & $\begin{array}{l}\text { - não conhecer bem a "cultura" da } \\
\text { construtora } \\
\text { - pouca familiaridade com produção } \\
\text { - formação tecnológica insuficiente } \\
\text { - menor agilidade na interface com equipes } \\
\text { de campo }\end{array}$ \\
\hline $\begin{array}{l}\text { Profissional ligado à } \\
\text { construtora }\end{array}$ & $\begin{array}{l}\text { - conhece a "cultura" da construtora } \\
\text { - maior experiência na produção } \\
\text { - melhor ligação entre projeto e obra }\end{array}$ & $\begin{array}{l}\text { - influenciável por "vícios" da construtora } \\
\text { - tendência de favorecer custos } \\
\text { - pouco domínio das técnicas de projeto de }\end{array}$ \\
\hline
\end{tabular}


Em empreendimentos de reabilitação voltados à atualização dos sistemas prediais, visando torná-los mais eficientes, principalmente em edifícios comerciais onde o custo de operação e manutenção do edifício contribui para a valorização de mercado do imóvel, a função de coordenação de projetos pode ser exercida, por exemplo, por um consultor especialista em sistemas prediais, como destaca Thomaz (2001).

As principais vantagens do perfil de coordenação ligado à empresa construtora são a sua experiência na produção. Isso Ihe confere uma leitura da aplicabilidade do projeto de reabilitação e da sua construtibilidade, que poderá contribuir para que anteveja eventuais interferências na execução.

Em empreendimentos de reabilitação, dependendo da intensidade da intervenção realizada na edificação, a demanda do coordenador, como facilitador entre os agentes envolvidos na rotina do empreendimento, pode ser grande. O coordenador, caso tenha experiência em empreendimento de reabilitação e tenha desenvolvido experiência e conhecimento sobre coordenação desse tipo de empreendimento, certamente terá mais facilidade na condução das atividades do que aquele que se defronta pela primeira vez com essa situação.

Entretanto, mesmo assim, são muitas as atividades de coordenação em projetos de reabilitação. Por isso, é recomendável que um profissional seja dedicado exclusivamente à atividade de coordenação, principalmente em empreendimentos de reabilitação. 
Na Tabela 14 de Melhado et al (2005) é mencionada uma das características mais importantes para o coordenador de projetos em empreendimentos de reabilitação: "agilidade nas decisões e na validação das soluções de projeto propostas".

Em virtude da dinâmica de desenvolvimento dos projetos em empreendimento de reabilitação ser diferente de empreendimento "novos" ou convencionais e, muitas vezes, avançar a uma sobreposição entre as etapas de obra e projeto, é fundamental que o coordenador de projetos tenha capacidade de agilizar as decisões de projeto e validar as soluções propostas. Não raramente, as decisões de projetos são orientadas pelas demandas criadas pelas equipes de obra e as soluções de projetos são definidas de acordo com o andamento das obras.

Tabela 14 - Competências e conhecimentos úteis para o desempenho da coordenação de projetos (MELHADO et al, 2005)

\section{COMPETÊNCIAS E CONHECIMENTOS DO COORDENADOR}

$\checkmark$ Capacidade de identificação das atividades necessárias ao desenvolvimento do projeto;

$\checkmark$ Capacidade de gestão dos custos e programação dos recursos para o projeto;

$\checkmark$ Capacidade de previsão e controle de prazos;

$\checkmark$ Capacidade de tomada de decisões de caráter gerencial como a aprovação de produtos intermediários e a liberação para início de etapas do projeto;

$\checkmark$ Formação e experiência para identificação e caracterização das interfaces técnicas entre as especialidades;

$\checkmark$ Capacidade para estabelecer diretrizes e parâmetros técnicos relativos às características dos produtos, dos processos de aquisição e dos processos de execução envolvidos;

$\checkmark$ Capacidade de ordenação do fluxo de informações entre os agentes envolvidos;

$\checkmark$ Capacidade para analisar as soluções técnicas e o grau de solução global atingida;

$\checkmark$ Facilidade para lidar com problemas complexos e multidisciplinares;

$\checkmark$ Capacidade de seleção e formação de equipe segundo as capacitações/ especialidades demandadas pela natureza do empreendimento a ser projetado;

$\checkmark$ Liderança e presença de espírito para mediar e conduzir soluções negociadas;

$\checkmark$ Agilidade nas decisões e na validação das soluções de projeto propostas;

$\checkmark$ Capacidade de gerenciamento de alteração de escopo dos projetos; e

$\checkmark$ Gestão de conflitos

Entretanto, como a existência de imprevistos é uma das características mais marcantes dos empreendimentos de reabilitação, a rapidez na tomada de decisão 
na etapa de obra é igualmente importante. É de fundamental importância a presença de um profissional responsável pelo diligenciamento, que tenha uma visão sistêmica do empreendimento, inclusive do ponto de vista econômico-financeiro, e que tenha relacionamento próximo com o empreendedor.

A mudança de escopo dos projetos pode acontecer em empreendimentos de reabilitação, dentre outras razões, quando a etapa de diagnóstico não foi cumprida adequadamente. A falta de elementos importantes para elaboração dos projetos é convertida em premissas que, futuramente, precisam ser revistas e, conseqüentemente, o escopo do projeto é alterado. Ou, então, a dedicação de determinada empresa de projeto se torna maior do que a prevista no escopo original. Esses aspectos precisam ser geridos pelo coordenador de projetos, que deve ser capaz de gerenciar as alterações de escopo dos projetos.

Em virtude da atividade de coordenação de projetos exigir um relacionamento constante com os agentes envolvidos no empreendimento, segundo Novaes (1996) o profissional ainda deve ter as seguintes características:

$>$ facilidade de comunicação;

> capacidade de comprometer os participantes com os objetivos do empreendimento;

> capacidade para identificar as causas de impasses, e de resolvê-los, em áreas de interesses distintos.

\subsubsection{Modelos de coordenação de projetos}

A coordenação de projetos deve estabelecer mecanismos de controle de processos que permitam a gestão adequada dos diversos aspectos do empreendimento, tais como: atendimento a prazos, qualidade, custo, escopo, satisfação dos clientes etc.

Melhado et al (2005) propõem que os modelos de coordenação de projetos sejam diferentes para cada tipo e porte de empreendimento. A coordenação de projetos 
pode ser aplicada de diferentes maneiras para atingir seus objetivos e, para isso, deve estar adaptada ao tipo do empreendimento.

Para Manso (2006), embora a opção de se contratar os serviços de coordenação de projetos traga benefícios, dentre eles o de possibilitar que sejam agregadas informações das melhores práticas aplicadas por outras empresas (concorrentes), a principal desvantagem gerada pela falta de um coordenador interno é a não incorporação dos conhecimentos adquiridos ao know-how da empresa. Isso pode, segundo o autor, levar à oscilação no padrão de qualidade dos produtos, em função da falta de retroalimentação de todo o processo.

Para Fabricio, Melhado e Grilo (2003) "a coordenação de projetos exige a articulação e o questionamento das especialidades de projeto em benefício do todo". Para isso, complementam os autores, o coordenador deve possuir conhecimento multidisciplinar que contemple as esferas "produto" e "obra", além da capacidade de gerenciar o processo e integrar as equipes de projeto. Entretanto, devem ser consideradas as características específicas de cada empreendimento, de maneira que o modelo de coordenação adotado esteja alinhado com a estratégia competitiva e a capacidade técnica e gerencial das empresas. A relação de modelos de coordenação com os tipos de empreendimentos é apresentada na Tabela 15.

Tabela 15 - Modelos de coordenação e suas vantagens potenciais (adaptado de FABRICIO; MELHADO; GRILO, 2003)

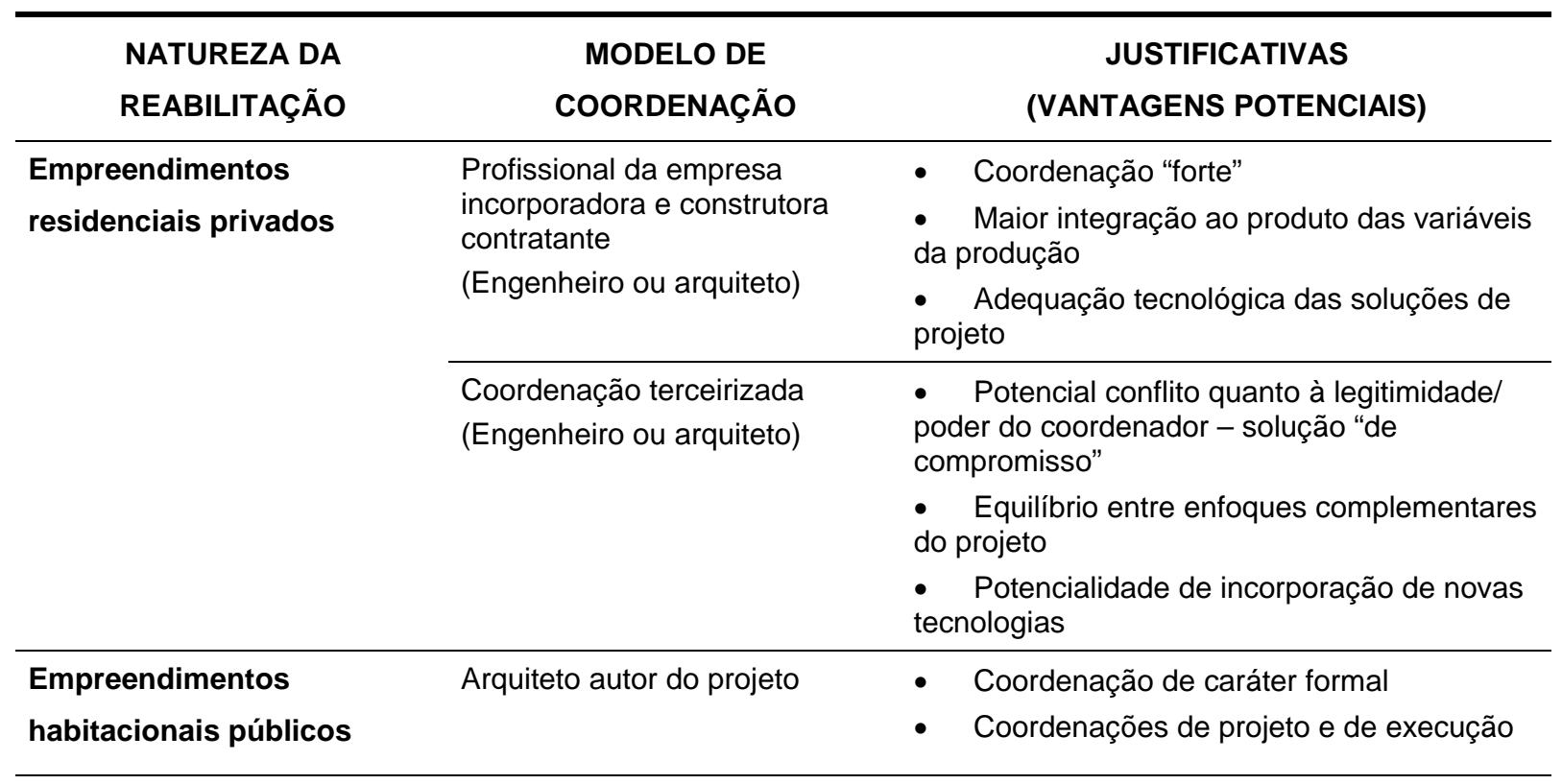




\begin{tabular}{|c|c|c|}
\hline & & são distintas \\
\hline $\begin{array}{l}\text { Empreendimentos } \\
\text { industriais }\end{array}$ & $\begin{array}{l}\text { Engenheiro responsável pela } \\
\text { concepção do processo de } \\
\text { produção industrial } \\
\text { (profissional interno ou externo) }\end{array}$ & $\begin{array}{l}\text { - } \quad \text { Prioridade aos objetivos do cliente } \\
\text { - } \quad \text { Funções não-produtivas em segundo } \\
\text { plano }\end{array}$ \\
\hline \multirow[t]{4}{*}{$\begin{array}{l}\text { Empreendimentos } \\
\text { comerciais }\end{array}$} & Arquiteto autor do projeto & $\begin{array}{l}\text { - Importância da função estética e da } \\
\text { imagem }\end{array}$ \\
\hline & $\begin{array}{l}\text { Engenheiro responsável pelos } \\
\text { sistemas prediais } \\
\text { (profissional interno ou externo) }\end{array}$ & $\begin{array}{l}\text { - } \quad \text { Prioridade aos objetivos do cliente } \\
\text { - } \quad \text { Funções não-produtivas em segundo } \\
\text { plano }\end{array}$ \\
\hline & & $\begin{array}{l}\text { Equilíbrio entre enfoques complementares } \\
\text { do projeto }\end{array}$ \\
\hline & & $\begin{array}{l}\text { - Adequação tecnológica das soluções de } \\
\text { projeto }\end{array}$ \\
\hline $\begin{array}{l}\text { Pequenos } \\
\text { empreendimentos }\end{array}$ & Arquiteto autor do projeto & - Menor peso das decisões técnicas \\
\hline
\end{tabular}

Segundo os autores, na reabilitação dos empreendimentos industriais ou comerciais onde há uma disciplina de projeto no centro das prioridades do empreendimento, o profissional especialista, ou o escritório de projetos responsável por essa disciplina, deverá assumir a coordenação dos projetos. Isso Ihe conferirá maior autonomia para decisões e uma visão sistêmica do empreendimento, o que contribuirá para que os objetivos do cliente sejam atendidos de maneira satisfatória.

Para Thomaz (2001), o coordenador de projetos deve zelar pelo atendimento da "filosofia" do empreendimento. Em outras palavras, é responsabilidade do coordenador orientar os trabalhos relativos ao projeto para que a cultura própria do empreendedor e/ou dos clientes seja garantida no empreendimento. 


\section{EXPERIÊNCIAS DE REABILITAÇÃO DE EDIFÍCIOS: ESTUDOS DE CASO}

Nesse capítulo serão apresentados os resultados dos três estudos de caso. Esta etapa do trabalho contempla os resultados da pesquisa de campo realizada em dois empreendimentos de reabilitação situados na cidade de São Paulo e um empreendimento situado na cidade de Lyon, França. Os casos nacionais apresentam dois modelos diferentes de gestão de projetos para empreendimentos de reabilitação, ambos localizados na região central de São Paulo. Já estudo de caso realizado em Lyon, França apresentará um terceiro modelo de gestão de projetos aplicado a um empreendimento, no qual a etapa de diagnóstico foi o fator principal. 
5.1 ESTUDO DE CASO 1: EDIFÍCIO ANA CINTRA (CENTRO - SÃO PAULO, SP)

\subsubsection{Histórico do empreendimento}

O estudo de caso que será apresentado a seguir, refere-se à reabilitação do Edifício Ana Cintra, também chamado de "Santa Cecília C" (Figura 25), situado à Rua Ana Cintra n. ${ }^{\circ}$ 123, esquina com Avenida São João, centro da cidade de São Paulo-SP.

O imóvel foi inserido no programa Pró-Lar-Atuação em Cortiços (PAC) da Companhia de Desenvolvimento Habitacional e Urbano do Estado de São Paulo (CDHU), empresa pública ligada à Secretaria de Habitação do Estado de São Paulo.
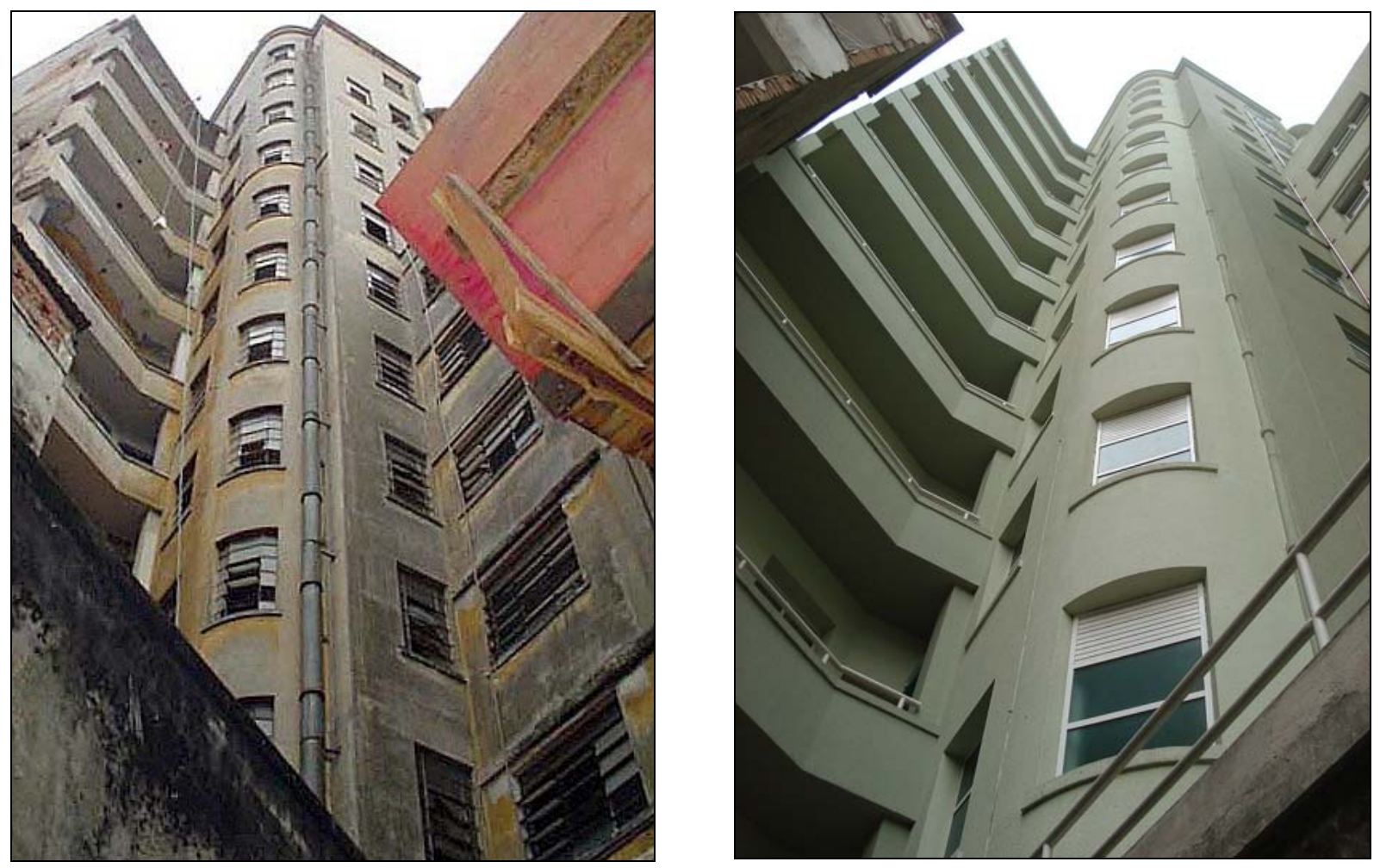

Figura 25 - Fachada dos fundos do Ed. Ana Cintra: antes (esq.) e após a reabilitação (dir.) fonte: arquivo do autor

O imóvel foi apresentado ao PAC/CDHU pelo Fórum dos Cortiços e Sem-Teto de São Paulo, entidade filiada à União dos Movimentos por Moradia - UMM, juntamente com a proposta de reabilitação e conversão para Habitação de Interesse Social 
(HIS). O público alvo desse empreendimento seriam famílias que residiam em cortiços localizados no centro da Capital.

Após análise da proposta e aquisição do imóvel, em abril de 1999, o PAC/CDHU autorizou a ocupação provisória do imóvel pelas famílias ligadas à entidade, até que os processos de contratação dos projetos e das obras de reabilitação fossem realizados. Em dezembro de 2001, as 81 famílias que ocupavam o Ed. Ana Cintra decidiram fundar a entidade denominada Movimento Sem-Teto do Centro - MSTC (CDHU-SGPAC, 2002) que assumiria, posteriormente, a interlocução direta com o PAC/CDHU sobre o destino do imóvel quando da sua reabilitação.

* PRÓ-LAR-ATUAÇÃo eM CORTIÇOS - PAC

O Pró-Lar-Atuação em Cortiços (PAC) é responsável pelo atendimento à população encortiçada dos grandes centros urbanos do Estado de São Paulo. Para isso, promove, além da reabilitação de edificações, a construção de imóveis para suprir essa demanda. O programa foi efetivamente implantado em junho de 2002 com a assinatura do contrato de empréstimo, junto ao Banco Interamericano de Desenvolvimento - BID, no valor de 70 milhões de dólares (CDHU-SGPAC, 2002).

A abrangência do programa na cidade de São Paulo foi orientada pelo levantamento cadastral e pesquisa sócio-econômica desenvolvida em conjunto com a Fundação Sistema Estadual de Análise de Dados (SEADE). Nesse trabalho, a área central da cidade foi mapeada em nove regiões denominadas Setores Básicos de Intervenção (SBI): Barra Funda/Bom Retiro, Brás, Bela Vista, Belém, Cambuci, Liberdade, Moóca, Santa Cecília e Pari, conforme ilustrado na Figura 26. Para cada SBI foram identificados os números de cortiços e quantificados tanto a população residente nos cortiços como os seus respectivos indicadores sócio-econômicos.

O Ed. Ana Cintra, objeto deste estudo, está localizado no chamado SBI-Santa Cecília. Nessa região foram identificados 123 cortiços contendo 1.437 domicílios que abrigavam, na época do levantamento, 3.214 moradores (CDHU-SEADE, 2002). 


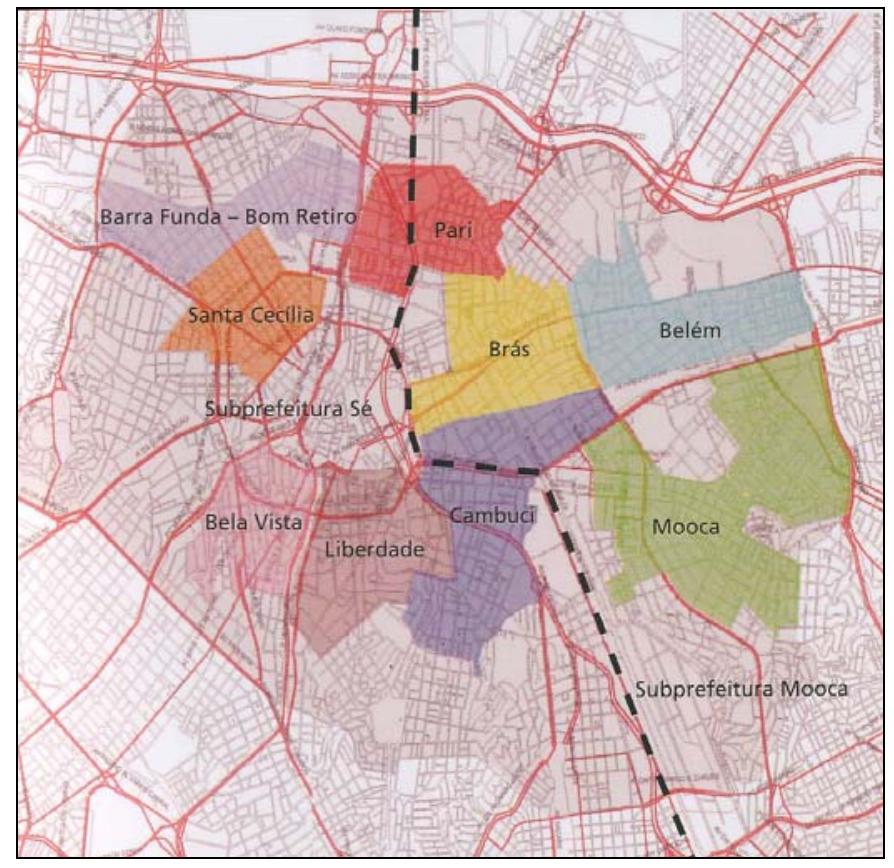

Figura 26 - Setores básicos de intervenção (SEADE-CDHU, 2002)

\subsubsection{Estudo de viabilidade}

No que diz respeito à viabilidade da operação de aquisição do Ed. Ana Cintra, um dos aspectos favoráveis que deu agilidade à sua comercialização foi o fato do imóvel ter sido registrado no cartório de imóveis com apenas uma matrícula, condição essa mantida pelo proprietário.

A aquisição de um edifício inteiro, quando ele possui diversos proprietários, tende a ser uma operação mais lenta e complexa em virtude dos diferentes interesses das partes envolvidas. No caso do Ed. Ana Cintra, como foi mantida uma única matrícula do imóvel desde a sua construção, a negociação com um único proprietário foi entendida como um aspecto facilitador pela CDHU na sua comercialização.

Do ponto de vista técnico, não foram realizadas investigações detalhadas nas condições do imóvel e no impacto do novo uso que seria atribuído à estrutura existente que subsidiassem o estudo de viabilidade técnico-comercial. 
O edifício projetado, na década de 1940, para abrigar 36 famílias, teria a sua ocupação adensada para 70 unidades habitacionais de interesse social. Para viabilizar esse adensamento seria necessário um incremento no número de elementos de vedação internos, o que implicaria na redistribuição das cargas atuantes na estrutura e fundação. Entretanto, não foram realizadas prospecções técnicas para análise desse impacto.

Devido ao elevado padrão de acabamento, conforme ilustrado na Figura 27, e o seu relativo bom estado de conservação, foi considerado o reaproveitamento dos materiais aplicados. Entretanto, para isso não foram realizados diagnósticos detalhados do estado de conservação e/ou mapeamento do potencial de reaproveitamento dos componentes e materiais aplicados na edificação, frente à nova redistribuição das unidades habitacionais.
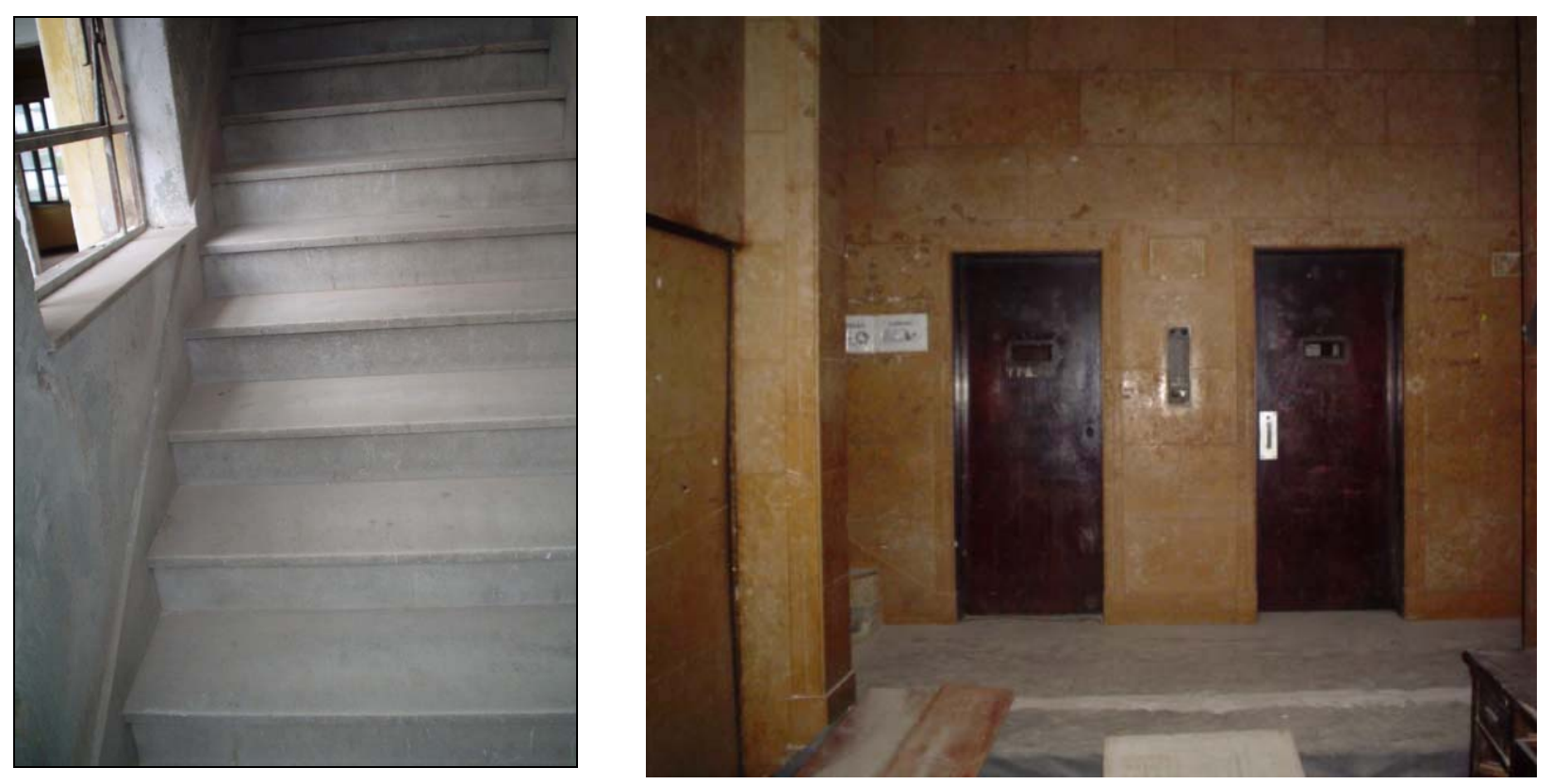

Figura 27 - Revestimento em mármore no piso da escadaria (esq.) e vista do hall de elevadores no pavimento térreo (dir.) - fonte: arquivo do autor

\subsubsection{Caracterização do empreendimento}


Os projetos originais de aprovação junto à Prefeitura Municipal de São Paulo (PMSP) foram localizados pela equipe do PAC. Datados de 1941, os projetos detalham, além dos 36 apartamentos (distribuídos em 10 andares), unidades comerciais no pavimento térreo e um pavimento no subsolo para abrigar a garagem de veículos (que não foi construído).

O projeto de reabilitação e conversão do edifício para habitação de interesse social fez com que as 36 unidades habitacionais (u.h's.) existentes dessem lugar a 70 novas u.h's., com área útil variando entre 42 e $55 \mathrm{~m}^{2}$. As unidades comerciais do pavimento térreo foram mantidas.

Para isso, as unidades, originalmente de 02 dormitórios, passariam a ter como tipologia padrão apenas 01 dormitório, 01 banheiro, 01 sala e cozinha conjugadas e 01 área de serviço.

Devido à descontinuidade da elevação do edifício, novas u.h's. foram distribuídas nos pavimentos da seguinte forma:

a. $\mathbf{1}^{\mathbf{0}}$ ao $\mathbf{6}^{\mathbf{0}}$ andar: 08 unidades habitacionais por pavimento (Figura 28):

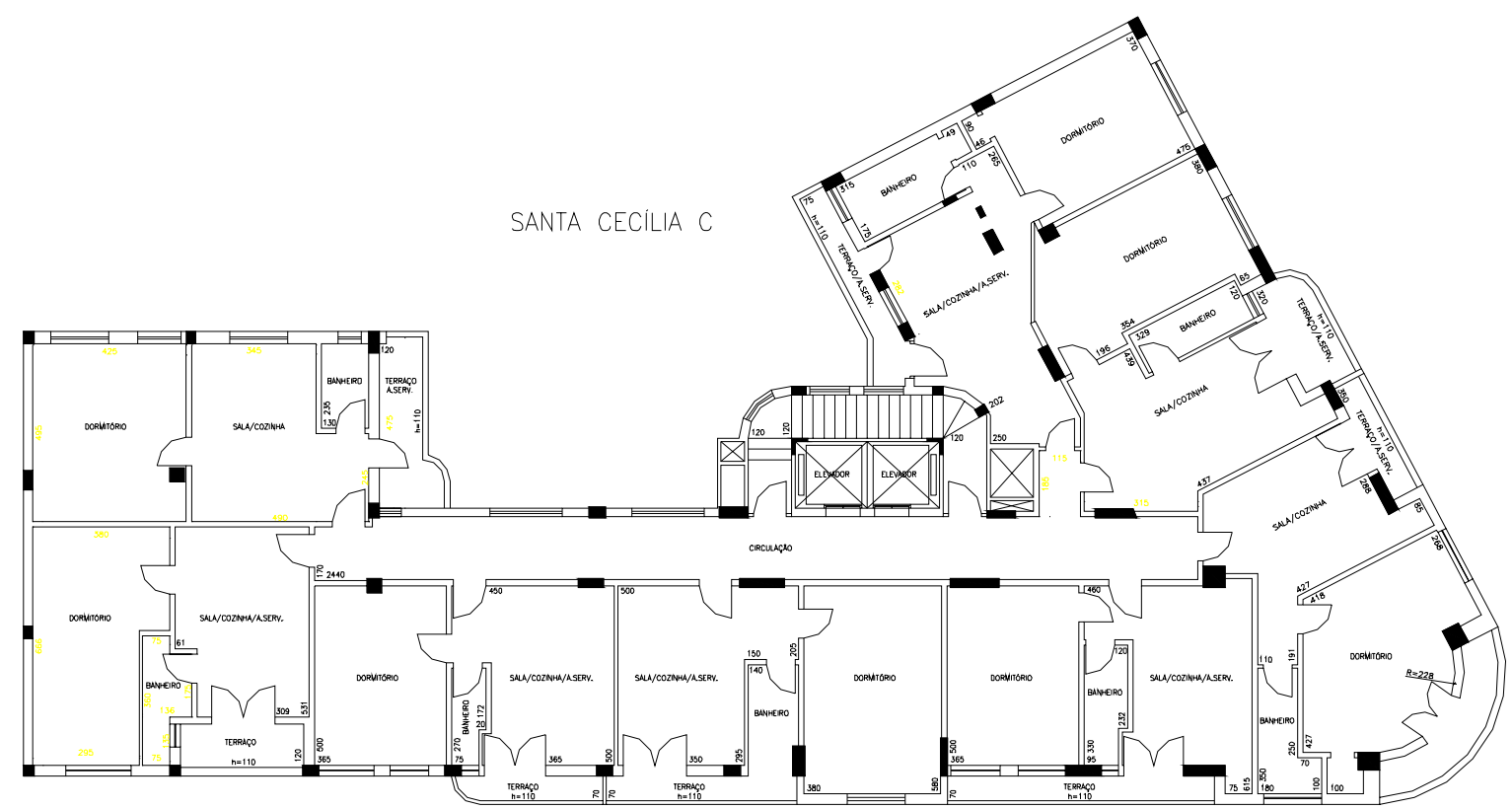

Figura 28 - Planta do projeto de reabilitação: $1^{\circ}$ ao $6^{\circ}$ pavimentos (fonte: CDHU) 
b. $\mathbf{7}^{\circ}$ ao $10^{\circ}$ andar: 05 unidades habitacionais por pavimento (Figura 29):

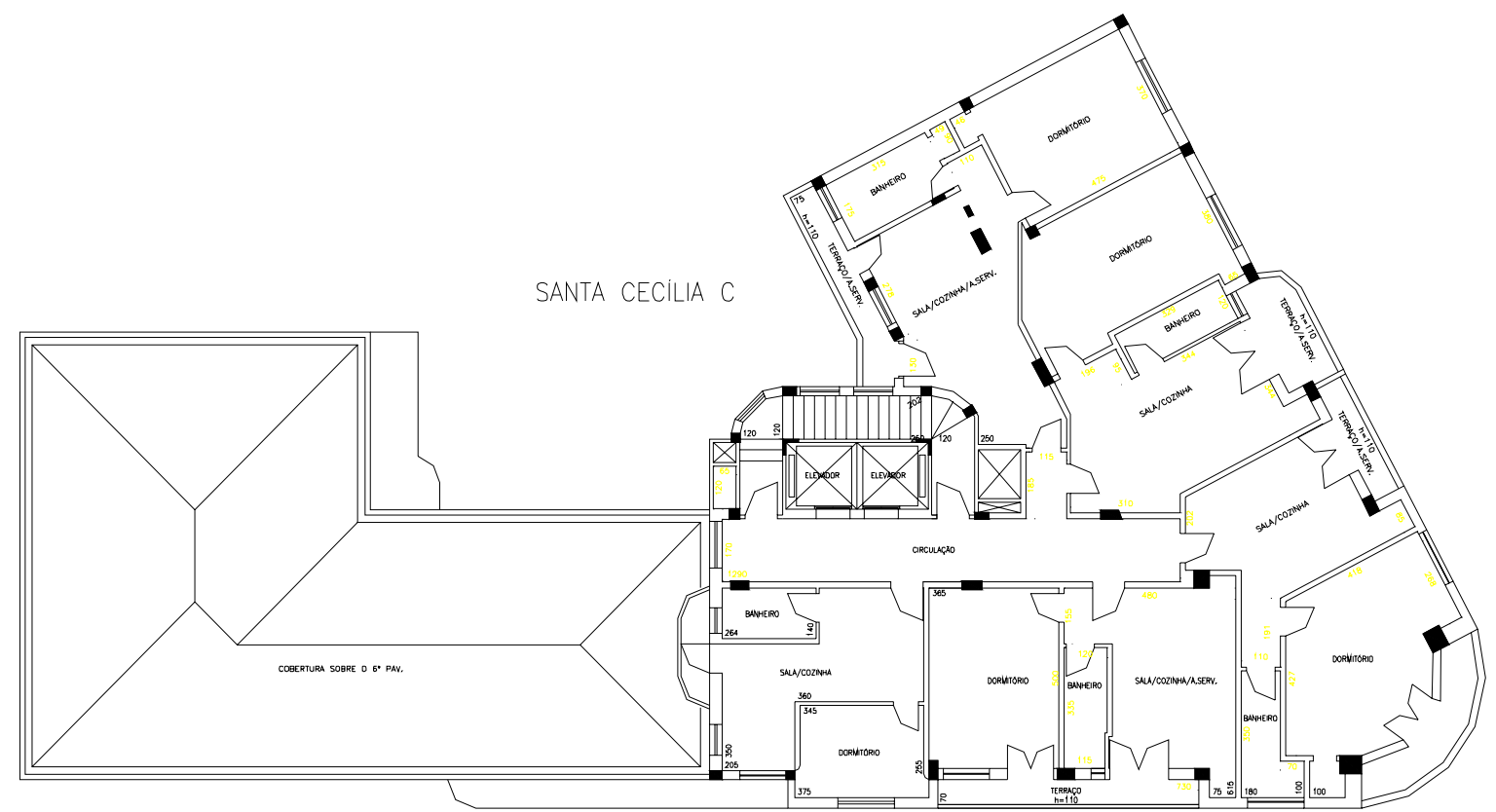

Figura 29 - Planta do projeto de reabilitação: $7^{\circ}$ ao $10^{\circ}$ pavimentos (fonte: CDHU)

c. $\mathbf{1 1}^{\circ}$ andar: $\mathbf{0 2}$ unidades habitacionais (Figura 30):

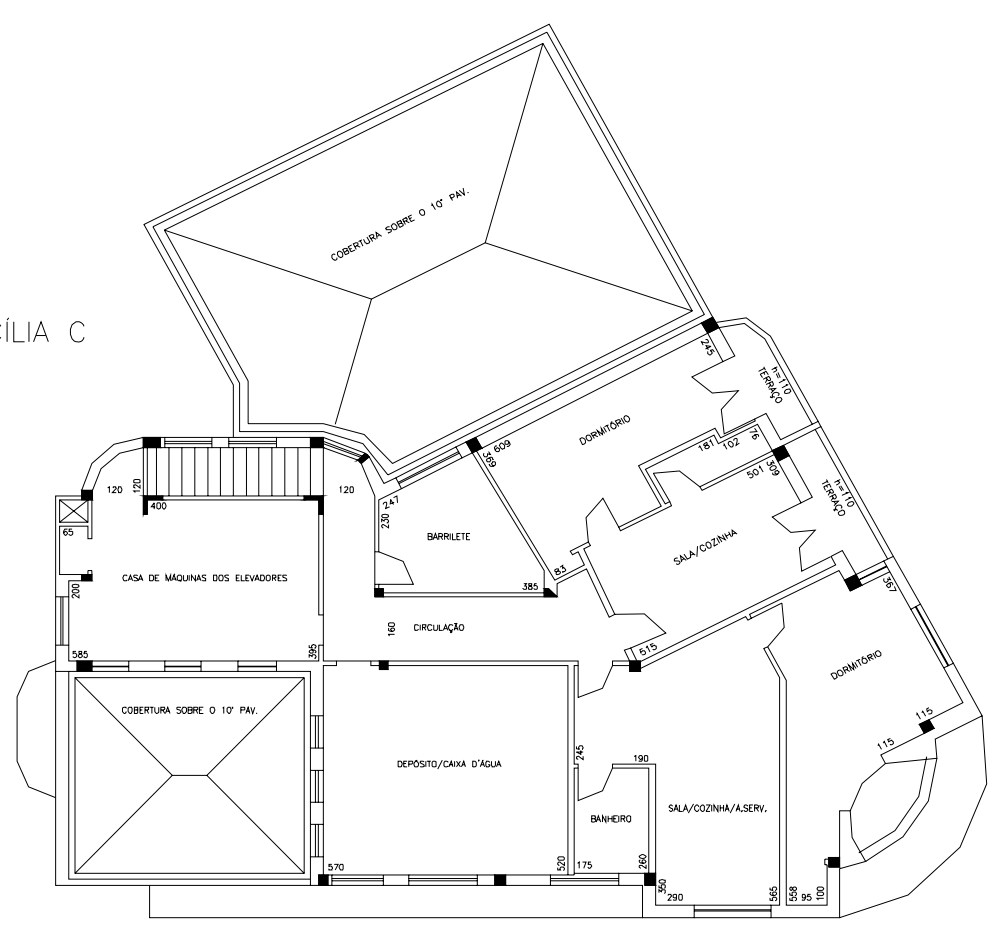

Figura 30 - Planta do projeto de reabilitação: $11^{\circ}$ pavimento (fonte: CDHU) 


\subsubsection{Organização do empreendimento}

O PAC conta com uma estrutura interna de gestão que atua no empreendimento em todas as fases: promoção da assistência à população encortiçada (público alvo), negociação das demandas junto aos movimentos populares de moradia, elaboração do programa de necessidades, contratação dos projetos, coordenação dos projetos, acompanhamento pós-ocupação etc.

A operacionalização das atividades de gestão do programa, assim como as de gerenciamento e fiscalização das obras, é apoiada por empresas contratadas, denominadas "gerenciadoras". No caso do Ed. Ana Cintra, a mesma empresa gerenciadora foi responsável pelo apoio à gestão do programa e pelo gerenciamento/ fiscalização das obras.

$\mathrm{Na}$ Figura 31 são apresentados as principais etapas e os produtos e agentes envolvidos durante a realização do empreendimento. A equipe de gestão do PAC está localizada no centro de todas as etapas, pois é a responsável pelo empreendimento e pela interlocução entre os agentes envolvidos (incluindo os departamentos de projetos e obras da Companhia).

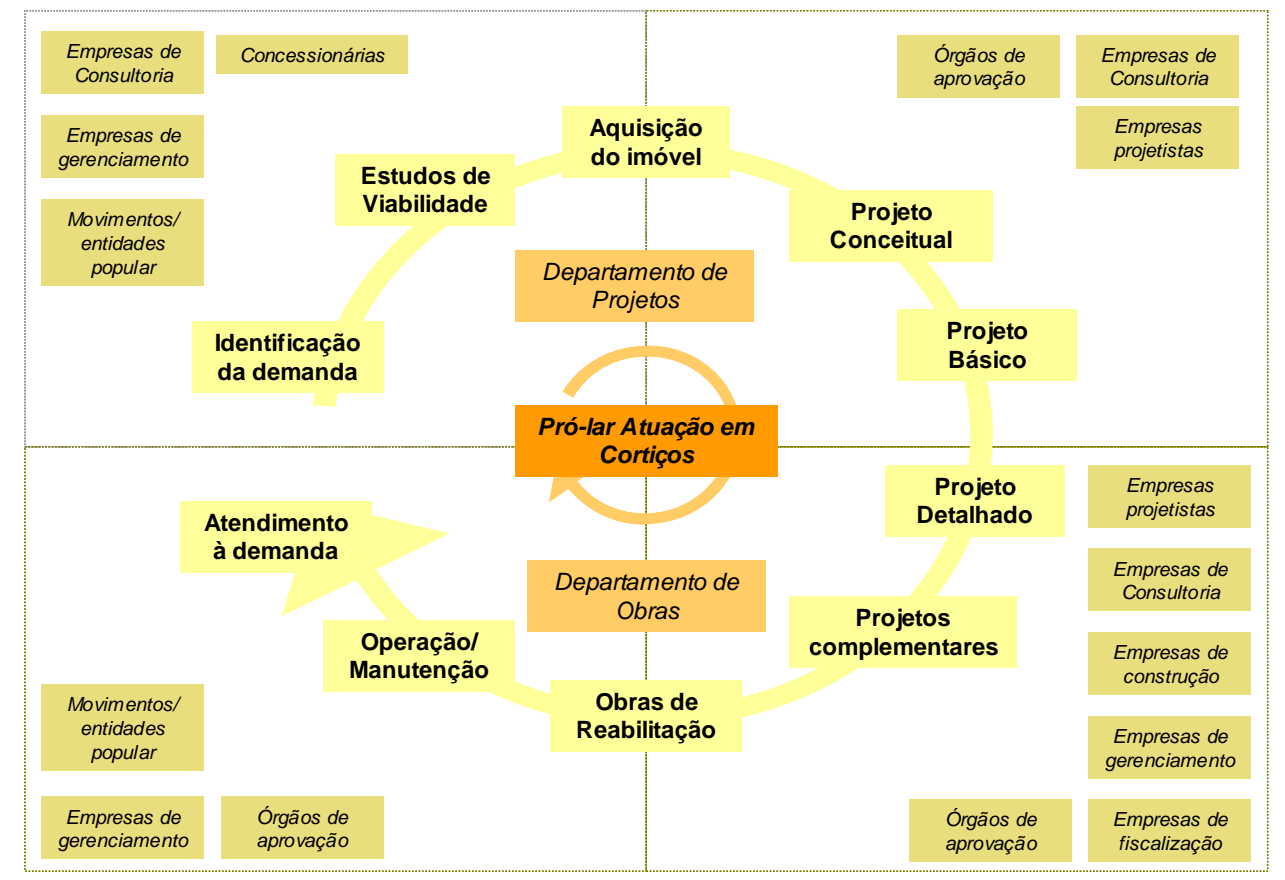

Figura 31 - Ciclos do empreendimento sob atuação da equipe de gestão do PAC (fonte: dados coletados junto à $\mathrm{CDHU}$ ) 
Em cada um dos quadrantes da figura foram indicados os principais agentes envolvidos nas etapas. Pode-se notar que a equipe de gestão do programa está sempre apoiada por empresas de gerenciamento.

\subsubsection{Estado geral da edificação}

A edificação, que se encontrava praticamente desocupada - apenas o funcionário que fazia a segurança do imóvel e sua família habitavam o edifício - foi ocupada por famílias que viviam em cortiços no centro da Capital. O período de ocupação duraria o prazo da licitação dos projetos e obras e da respectiva emissão da ordem de início dos serviços de reabilitação da edificação. Esse período de ocupação "provisória" foi de aproximadamente cinco anos, como mostra a Figura 32:

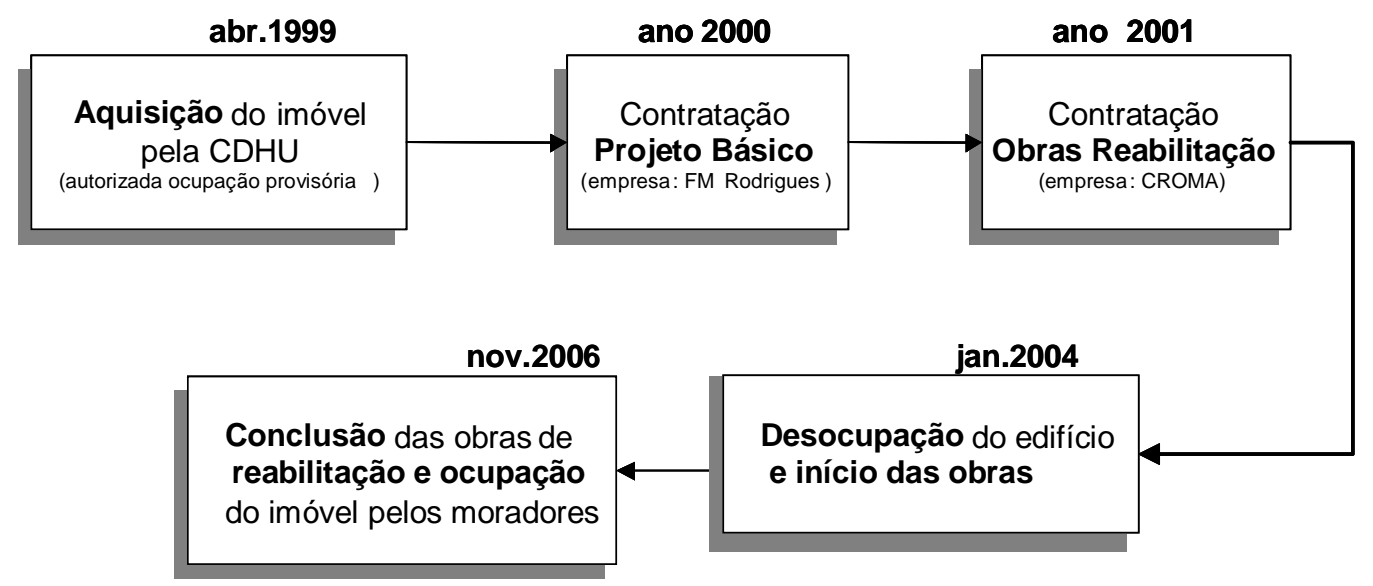

Figura 32 - Cronologia dos eventos: projeto e execução das obras de reabilitação (fonte: dados coletados junto à $\mathrm{CDHU}$ )

Como a ocupação do imóvel foi feita por um número de famílias superior às 36 unidades habitacionais existentes até então, durante o período de ocupação as adaptações no imóvel foram sendo realizadas pelos próprios moradores e, conforme as suas necessidades circunstanciais (Figura 33). 


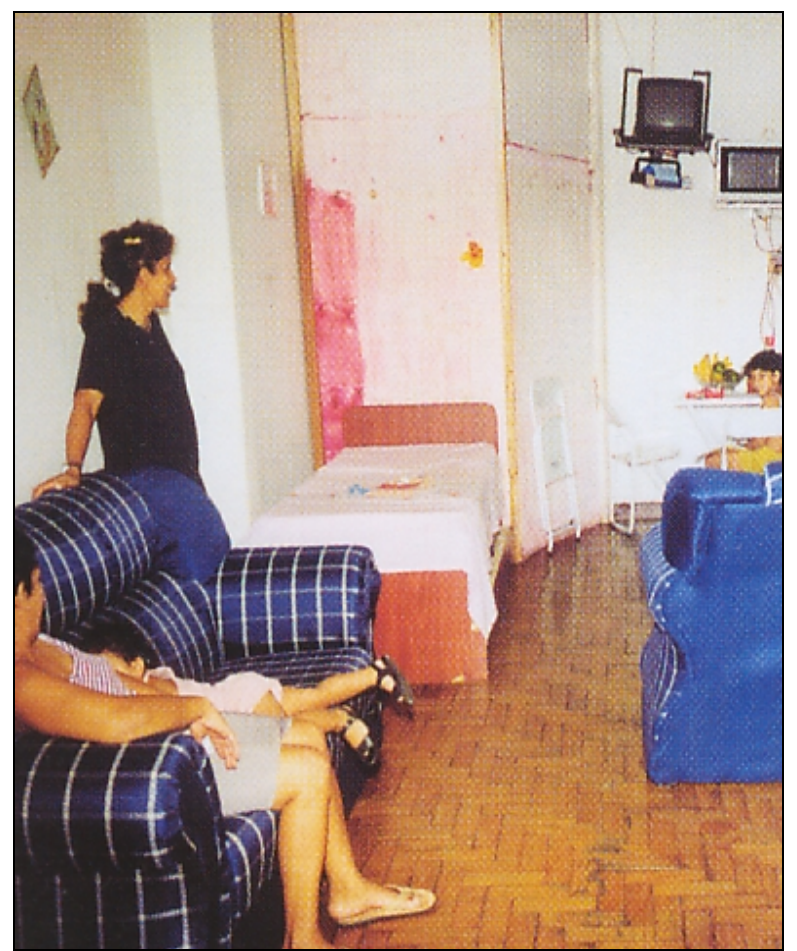

Figura 33 - Famílias do Movimento Sem-teto do Centro que ocuparam o Ed. Ana Cintra (CDHU-SGPAC, 2002)

Durante os cinco anos de ocupação não foram realizados serviços de manutenção predial e o estado geral da edificação tornou-se diferente daquele que serviu de base para elaboração dos documentos licitatórios, apresentado na época da aquisição do imóvel. Após a desocupação do imóvel, foram encontrados batentes e portas arrombadas, janelas de madeira e persianas danificadas (Figura 34), azulejos e pisos quebrados etc.
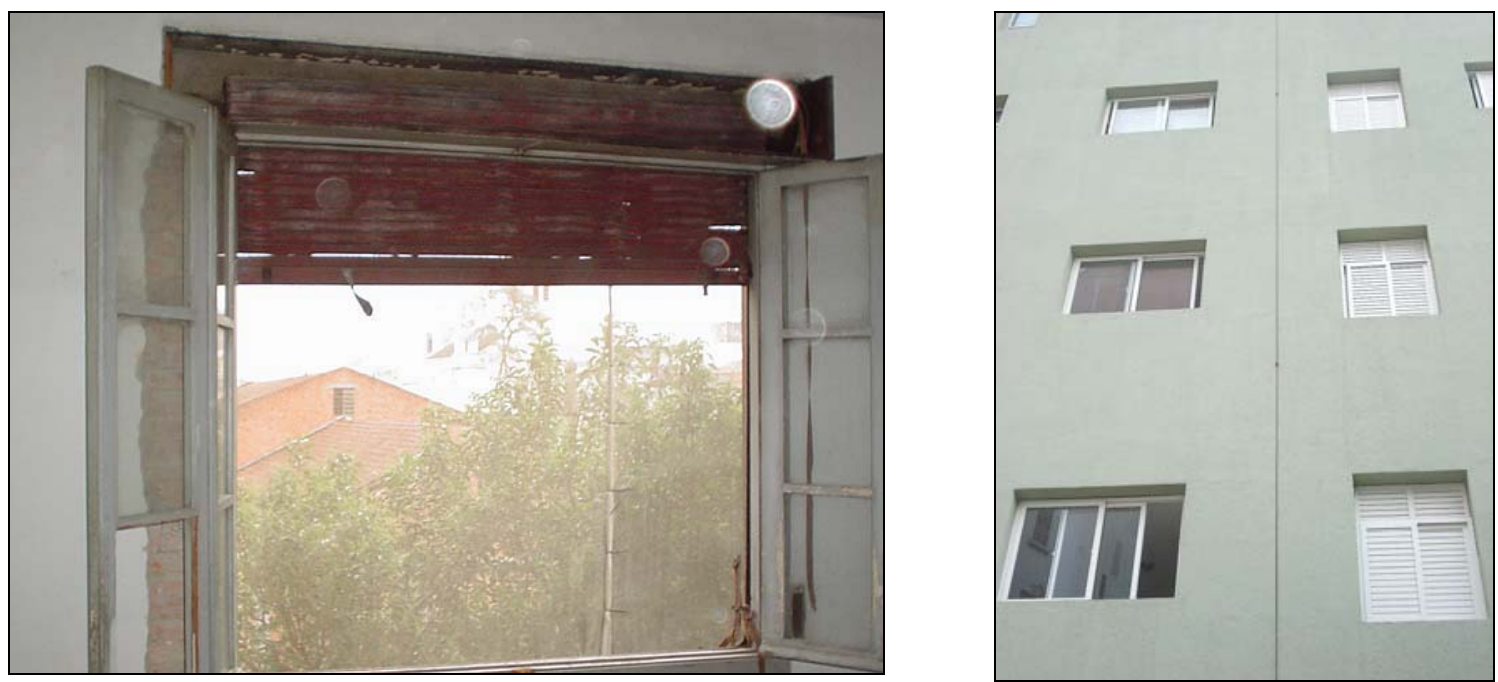

Figura 34 - Parte dos caixilhos e persianas de madeira foram substituídos caixilhos de PVC na reabilitação (dir.) - fonte: arquivo do autor 
O escopo original das obras de reabilitação havia sido alterado. Além disso, fez-se necessária a reavaliação das diretrizes de projeto, pois o reaproveitamento de parte dos materiais de acabamento e componentes, inicialmente previsto, estava comprometido.

\subsubsection{O processo de projeto}

\subsubsection{DESENVOLVIMENTO E FORMALIZAÇÃO DO PRODUTO}

O programa de necessidades que foi desenvolvido pela equipe técnica do PAC deu subsídio à elaboração dos projetos básicos. Estes projetos foram desenvolvidos tomando, como base, o estado de conservação do edifício quando da sua aquisição pela CDHU. Estes documentos, por sua vez, foram utilizados no edital licitação para contratação das obras de reabilitação.

As diretrizes de projeto inicialmente indicavam o reaproveitamento integral dos componentes e revestimentos existentes (Figura 35). Os pisos de taco de madeira dos apartamentos deveriam ser mantidos originais, assim como os azulejos, as esquadrias de madeira, os pisos de mármore das escadarias, as cabines dos elevadores etc.

Essa decisão se justificou pelo fato de que, inicialmente, os materiais estarem em boas condições para a reutilização, serem de boa qualidade e terem padrão de qualidade superior ao usualmente utilizado nas construções de padrão popular. 

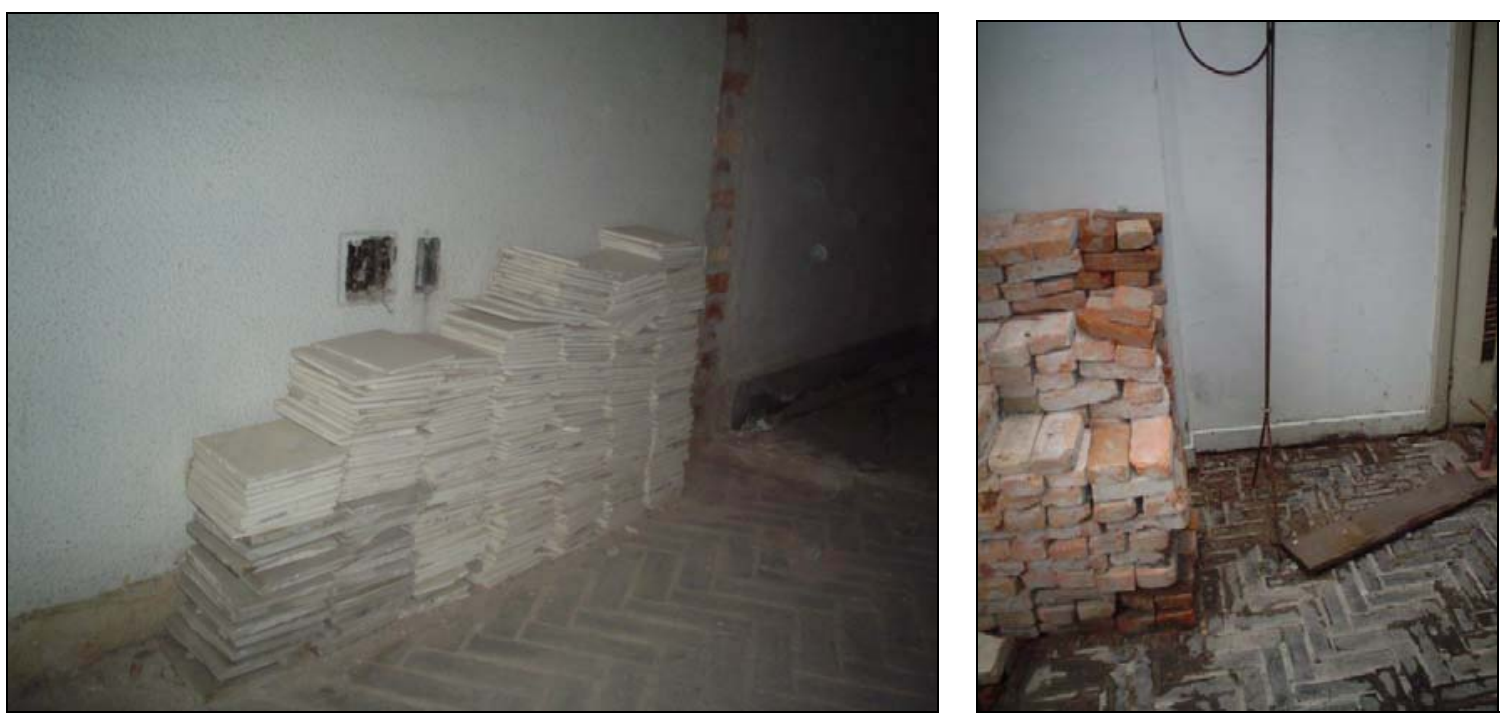

Figura 35 - Materiais aplicados na edificação: reutilização descartada (esq.). Piso de taco de madeira e tijolos de barro removidos das paredes demolidas (dir.) - fonte: arquivo do autor

Os sistemas prediais existentes, como instalações elétricas e hidráulicas, foram descartados para a reutilização. Entretanto, visando a redução de custos do empreendimento, não foi previsto a sua remoção. As instalações deveriam ser executadas em um novo traçado.

Apenas dois dos três elevadores existentes deveriam ser reativados no projeto de reabilitação. Para que fosse possível o aumento do número de unidades habitacionais nos pavimentos, foi prevista a demolição completa das alvenarias internas de vedação existentes. A redistribuição dos espaços foi projetada, inicialmente, com a execução de alvenaria de vedação de blocos cerâmicos. No pavimento térreo, as unidades destinadas ao uso comercial foram mantidas.

\subsubsection{DETALHAMENTO DO PRODUTO}

No início da execução das obras, o projeto básico sofreu alterações, como apresentado na Tabela 16. As distribuições internas das unidades habitacionais seriam redefinidas, em virtude da alteração da locação das paredes internas. 
Dentre as principais alterações, destacam-se a incorporação da cozinha à sala e, nos banheiros de 24 apartamentos, a ventilação prevista foi insuficiente, sendo necessária a adoção de ventilação mecanizada.

Tabela 16 - Alterações das soluções nas fases do projeto (dados coletados junto à CDHU)

\begin{tabular}{|c|c|c|c|}
\hline & Projeto Original & \multicolumn{2}{|c|}{ Projeto Reabilitação } \\
\hline & $\begin{array}{c}\text { "Como Construído" } \\
\text { (déc. 40) }\end{array}$ & $\begin{array}{l}\text { Projeto Básico } \\
\text { (ano 2000) }\end{array}$ & $\begin{array}{l}\text { Projeto Executivo } \\
\text { (ano 2004) }\end{array}$ \\
\hline 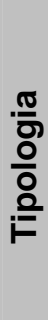 & $\begin{array}{l}\text { - } 36 \text { apartamentos (total) } \\
\text { - } 02 \text { dormitórios / apto } \\
\text { - WC - ventilação natural } \\
\text { - } 03 \text { elevadores } \\
\text { - Sala: independente }\end{array}$ & $\begin{array}{l}\text { - } 70 \text { apartamentos (total) } \\
\text { - } 01 \text { dormitório / apto } \\
\text { - WC - ventilação natural } \\
\text { - } 02 \text { elevadores } \\
\text { - Sala: independente }\end{array}$ & $\begin{array}{l}\text { - } 70 \text { apartamentos (total) } \\
\text { - } 01 \text { dormitório / apto } \\
\text { - WC - instalação de ventilação motorizada } \\
\text { em } 24 \text { unidades } \\
\text { - } 02 \text { elevadores } \\
\text { - Sala e cozinha conjugadas }\end{array}$ \\
\hline 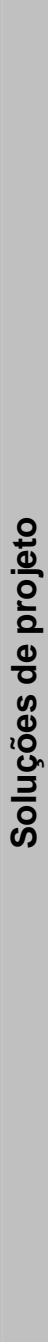 & $\begin{array}{l}\text { Revestimento interno: } \\
\text { - piso: cerâmico e taco de } \\
\text { madeira } \\
\text { - parede: cerâmico, mármore e } \\
\text { pintura } \\
\text { - piso escadaria: mármore } \\
\text { Esquadria de madeira: } \\
\text { - porta, janelas, batentes } \\
\text { - persiana } \\
\text { - porta tipo balcão das } \\
\text { varandas }\end{array}$ & $\begin{array}{l}\text { Revestimento interno: } \\
\text { - reaproveitamento dos } \\
\text { revestimentos (piso e parede) } \\
\text { Esquadria: } \\
\text { - reforma das esquadrias } \\
\text { Elementos de vedação: } \\
\text { - blocos cerâmicos } \\
\text { Sistemas prediais: } \\
\text { - instalações elétricas, hidráulicas e } \\
\text { de gás: abandono das existentes e } \\
\text { execução de novas instalações } \\
\text { convencionais }\end{array}$ & $\begin{array}{l}\text { Revestimento interno: } \\
\text { - substituição dos revestimentos (piso e } \\
\text { parede) } \\
\text { Esquadria: } \\
\text { - troca das esquadrias internas } \\
\text { Elementos de vedação: } \\
\text { - blocos de concreto celular } \\
\text { - alteração da marcação das paredes } \\
\text { internas: revisão no leiaute } \\
\text { Sistemas prediais: } \\
\text { • instalações elétricas, hidráulicas e de } \\
\text { gás: abandono das existentes e execução } \\
\text { de novas instalações. } \\
\text { - Sistema individualizado de medição de } \\
\text { consumo de água. } \\
\text { - shaft central único no pavimento (com } \\
\text { utilização da caixa do elevador desativado) } \\
\text { • instalações lançadas sobre forro de } \\
\text { gesso } \\
\text { Estrutura: } \\
\text { - criação de área de convivência: laje de } \\
\text { cobertura no } 6{ }^{\circ} \text { pavimento }\end{array}$ \\
\hline
\end{tabular}


As alterações no projeto básico ocorreram após o início da contagem do prazo de execução das obras, previsto para 12 meses.

\section{* Estrutura}

O edifício foi construído em estrutura de concreto armado convencional e, portanto, a demolição das paredes internas de vedação não representaria um risco à sua estabilidade estrutural. Entretanto, o projeto de reabilitação previa a execução de novas paredes em posições diferentes. Segundo o consultor especialista em estruturas, contratado pela empresa construtora, os esforços gerados pelas cargas destas novas paredes solicitariam a estrutura de maneira diferente daquela para qual fora dimensionada. O deslocamento dessas paredes do eixo das vigas provocaria novos esforços na estrutura.

A alternativa adotada para solucionar essa questão foi a de aliviar as cargas dessas novas paredes com a substituição do sistema, antes de bloco cerâmico, para bloco de concreto celular. A empresa de consultoria de estruturas ainda realizou avaliações das seções dos elementos estruturais da edificação, inspeção visual da estrutura e a retirada de testemunhas para ensaios de resistência. Pelos resultados obtidos, o aumento do número de apartamentos e, por conseqüência, o aumento da taxa de ocupação previsto no projeto básico, foi aprovado.

Outros aspectos nos quais a consultoria de estrutura teve que atuar foram a especificação e o detalhamento da laje de cobertura do $6^{\circ}$ andar, no trecho em que há descontinuidade na elevação. Nesse local, o projeto básico indicava o aproveitamento da laje de cobertura, supostamente existente, que serviria como área de convivência do condomínio.

Após o início dos trabalhos de demolição no local, descobriu-se que não havia laje de concreto na cobertura no $6^{\circ}$ andar, mas, sim, um forro executado em estuque. 0 projeto de estrutura definiu os elementos estruturais que deveriam ser executados para a criação da área de convivência sobre a laje de cobertura do $6^{\circ}$ andar, conforme ilustrado na Figura 36. 

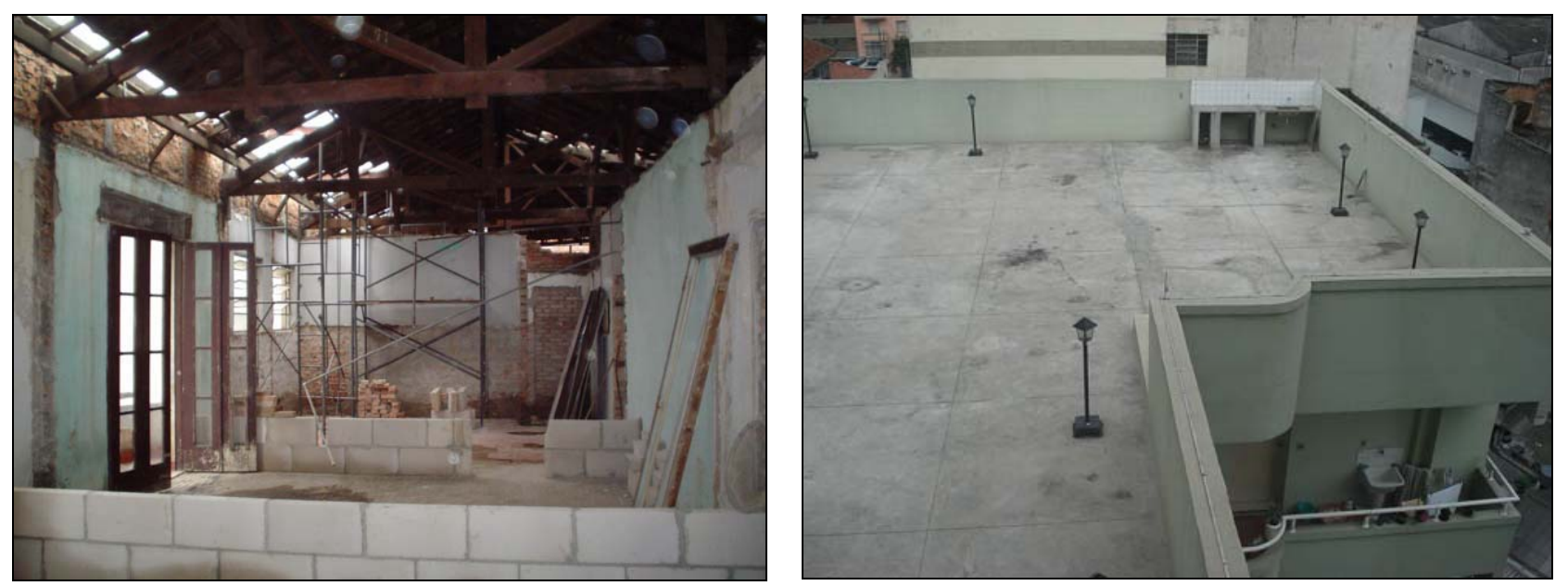

Figura 36 - Vista parcial do $6^{\circ}$ pavimento após remoção do forro (esq.) e área de convivência sobre laje de cobertura do $6^{\circ}$ pav., executada na reabilitação (dir.) - arquivo do autor

\section{* Sistemas prediais}

Em função do estado de conservação, do posicionamento das novas alvenarias de vedação internas e do fato de alguns dos materiais, aplicados na ocasião da construção do edifício, não estarem de acordo com as novas exigências prescritas nas normas técnicas, não foi previsto o aproveitamento das instalações elétricas, hidráulicas e de gás.

Embora o projeto básico tenha previsto o simples abandono das instalações existentes, parte delas foi removida durante a execução das obras. As instalações previstas no projeto básico orientavam a execução de um novo centro de medição e as distribuições nos pavimentos da maneira convencional. Entretanto, no início da execução das obras, foi estudada a utilização de um novo sistema unificado de leitura nas instalações, denominado medição remota.

Este sistema descartaria a execução do centro de medição no pavimento térreo, possibilitando a leitura do consumo de energia, água e gás a partir de equipamento instalado nos pavimentos. Além disso, o sistema possibilitaria a leitura de consumo individual, para os três tipos de fornecimento, de cada unidade habitacional. Entretanto, esse sistema não foi viabilizado. A empresa construtora contratou uma empresa projetista de sistemas prediais que desenvolveu o novo projeto dos sistemas prediais convencionais, mas com medição do consumo de água individualizado para os apartamentos, conforme ilustrado na Figura 37. 

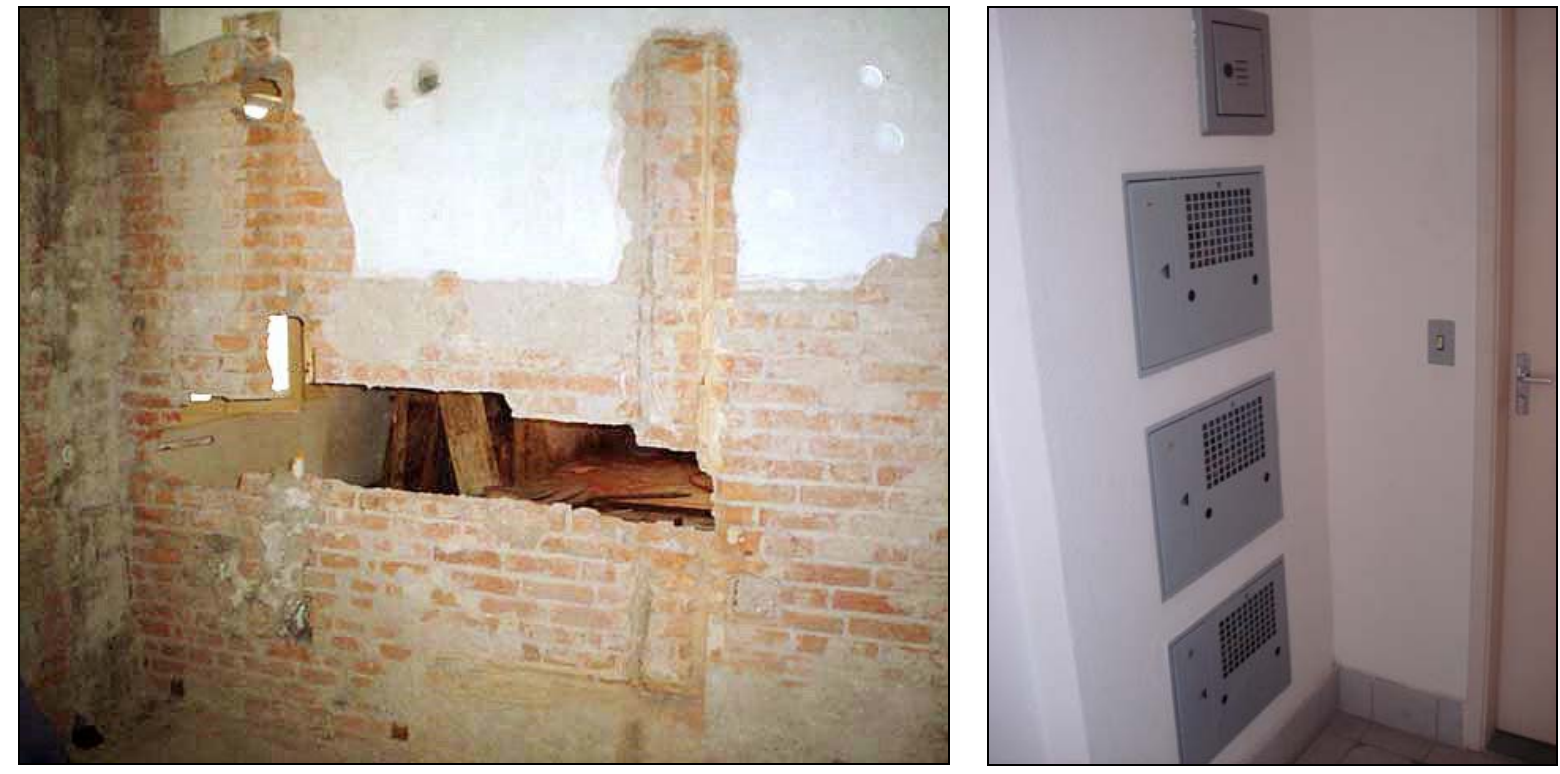

Figura 37- Remoção das instalações não prevista no projeto básico (esq.). À direita, medição individual do consumo de água dos apartamentos executada - arquivo do autor

Internamente às unidades habitacionais, o caminhamento das tubulações foi executado acima do forro de gesso. Um dos elevadores foi desabilitado para servir de caminhamento vertical das instalações entre pavimentos. Seu duto serviu de shaft central.

\subsubsection{Interface projeto - obra}

O conjunto de serviços para a reabilitação do Ed. Ana Cintra foi licitado e a concorrência ganha por uma empresa construtora que, embora tivesse experiência em executar obras de habitação de interesse popular, não possuía histórico de execução de obras de reabilitação de edifícios.

A modalidade de contratação definida na licitação foi a de contrato a "preço global". Ou seja, por uma determinada quantia ofertada, a empresa construtora devia executar todos os serviços previstos nos documentos técnicos do edital de licitação. Entre esses documentos técnicos, encontravam-se os projetos básicos, já bastante explorados neste trabalho. 
As alterações do escopo contratual se iniciaram no momento da mobilização da empresa construtora. A situação em que a edificação se encontrava, após a desocupação, era diferente daquela prevista nos projetos básicos. Além disso, as condições de trabalho no canteiro eram adversas. Passados oito meses do inicio das obras, o canteiro de obra não contava com o fornecimento de energia elétrica pela concessionária que, por falta de pagamento pelas famílias que ocuparam o edifício, interrompeu o fornecimento até que a situação fosse regularizada.

Um dos serviços liberados para execução, seguindo o projeto básico, foi o de demolição das paredes internas e, após o seu início, foi dada autorização para a remoção e o não reaproveitamento das portas e batentes danificados. A construtora canalizou o transporte vertical do entulho da demolição pela caixa de um dos elevadores até a caçamba localizada na rua junto ao passeio público.

Para atender à redistribuição das unidades habitacionais nos pavimentos, não seria possível o reaproveitamento das paredes existentes. A nova locação das paredes internas dos apartamentos foi feita através de uma prévia locação de tijolos de barro, orientada pelo projeto básico. Essa locação foi deslocada até que o novo posicionamento fosse aprovado. As equipes da CDHU definiram, no canteiro, a melhor distribuição dos ambientes nos apartamentos e liberaram a frente de serviços para a execução das alvenarias (Figura 38). Nesse momento, as atividades de coordenação dos projetos, que seriam responsabilidade da CDHU, foram compartilhadas com a empresa construtora que havia contratado os projetos e os serviços de consultoria. 

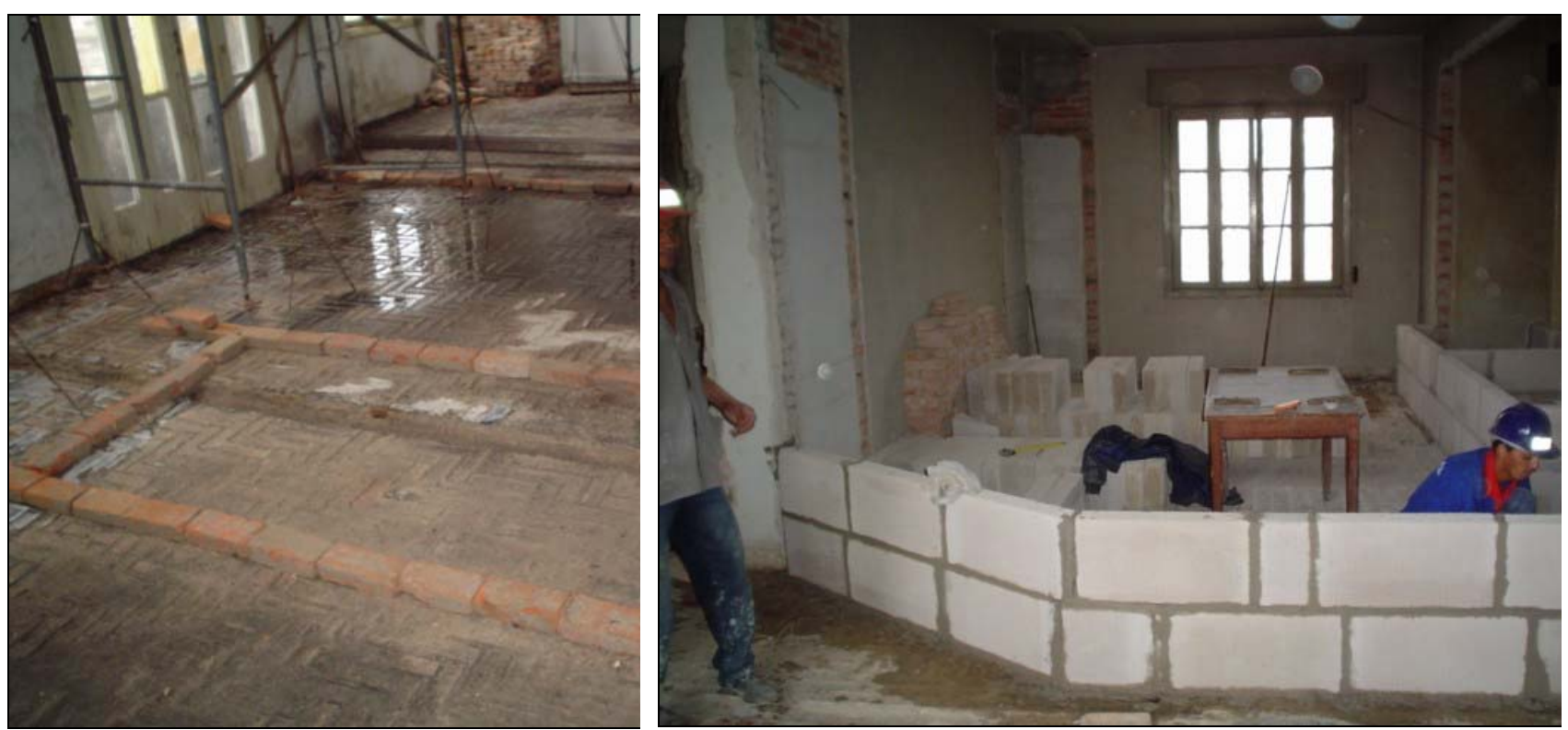

Figura 38 - Marcação de alvenaria (esq.) aguarda liberação para início da execução (dir) - fonte: arquivo do autor

Entretanto, ao mesmo tempo em que as novas locações das paredes internas eram aprovadas, parte do reaproveitamento previsto dos revestimentos de piso era comprometido. Alguns ambientes ficariam parte com revestimento de ladrilho hidráulico, parte com piso de taco de madeira. Em outros casos, o reaproveitamento do piso foi possível, entretanto houve descontinuidade na paginação (Figura 39).
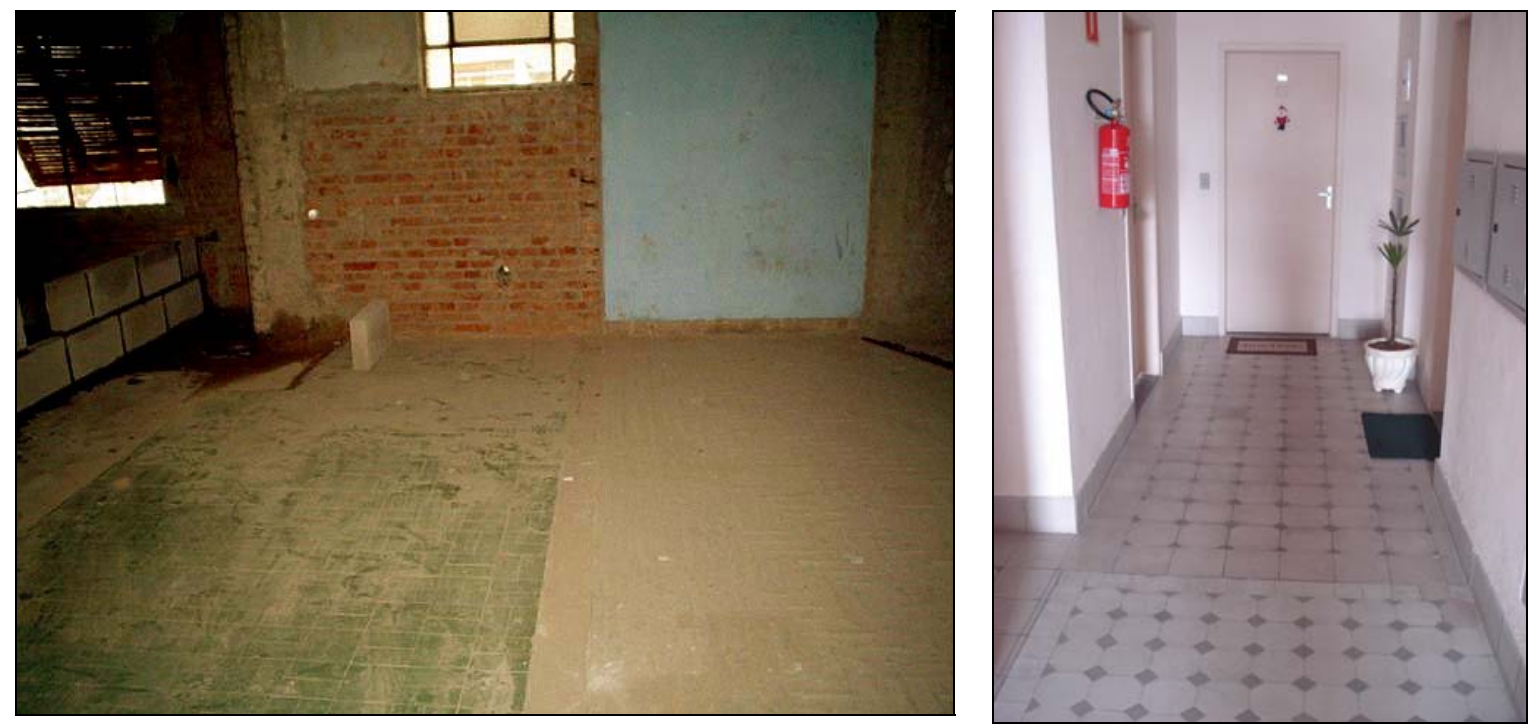

Figura 39 - Ambiente com diferentes tipos de revestimentos antes da reabilitação (esq.). À direita, reaproveitamento do material é evidenciado na descontinuidade do piso (fonte: arquivo do autor) 
A partir dessas informações, os projetos foram revisados e a construtora pôde dar início aos serviços de execução da alvenaria. A revisão dos projetos de arquitetura foi desenvolvida em conjunto com a execução das obras.

A possibilidade de se encontrarem interferências entre os projetos de reabilitação e a estrutura existente foi minimizada no caso estudado, uma vez que as definições de projeto aconteciam em conjunto com a execução da obra. Mas, se por um lado o risco de retrabalho diminuiu, por outro, a produtividade da execução das obras foi inferior ao previsto. O momento e o ritmo em que as definições de projeto foram tomadas não estavam previstos no escopo original de contratação das obras de reabilitação, o que ocasionou um aumento dos custos indiretos do contrato.

\subsubsection{Lições aprendidas e comentários finais}

O interesse do poder público na reabilitação das edificações localizadas no centro da cidade de São Paulo reforça a importância do reaproveitamento dos recursos aplicados tanto nas edificações quanto na infra-estrutura dos arredores.

Evidencia-se, neste estudo de caso, a necessidade da etapa de diagnóstico para subsidiar a análise de viabilidade e a elaboração dos projetos. O prazo do empreendimento poderia ter sido reduzido caso parte das interferências encontradas, na etapa da execução das obras, tivesse sido identificada anteriormente, na etapa de diagnóstico.

Para que o ritmo das obras de reabilitação seja mais eficiente, as definições de projeto devem ser antecipadas e podem utilizar o espaço físico existente (edificação a ser reabilitada) para experimentar as alternativas de projeto.

Além disso, a experiência anterior em empreendimentos de reabilitação, pelas empresas contratadas, pode colaborar com o resultado do empreendimento (custo, prazo e qualidade). A experiência da empresa de projetos pode colaborar com as especificações de materiais e componentes adequados aos processos de 
reabilitação (bloco cerâmico $\mathrm{x}$ bloco de concreto celular). Por outro lado, a experiência prévia da empresa construtora pode colaborar com a orçamentação adequada dos serviços a serem executados, no que diz respeito a índices de produtividade, consumo de materiais e custos indiretos.

Os estudos de viabilidade técnica precisam ser melhor detalhados e devem considerar os efeitos de sobreadensamento (em HIS, principalmente) sobre estrutura, resistência e estabilidade estrutural quando há redistribuição de cargas (mudança da locação dos elementos de vedação internos), condições e mapeamento dos materiais e componentes para o reaproveitamento.

O papel da coordenação de projetos, embora tenha sido estabelecido no início do empreendimento como de responsabilidade da CDHU, em virtude das circunstâncias do empreendimento acabou sendo desempenhado, em partes, pela empresa construtora. A intermediação entre as diversas disciplinas de projeto ficou a cargo da empresa construtora, uma vez que foi ela quem contratou e geriu os contratos das empresas projetistas e de consultoria. 
5.2 ESTUDO DE CASO 2: CONDOMÍNIO PIAZZA SAN PIETRO (MOÓCA - SÃO PAULO, SP)

\subsubsection{Histórico do empreendimento}

Até o relançamento do Piazza San Pietro, condomínio com 4 edifícios, 340 unidades habitacionais de 3 e 4 dormitórios, localizado na Rua Marina Crespi, no 118, no bairro paulistano da Moóca, não constava no currículo da empresa Tecnisa um único empreendimento de reabilitação e tão pouco havia interesse nesse nicho de mercado.
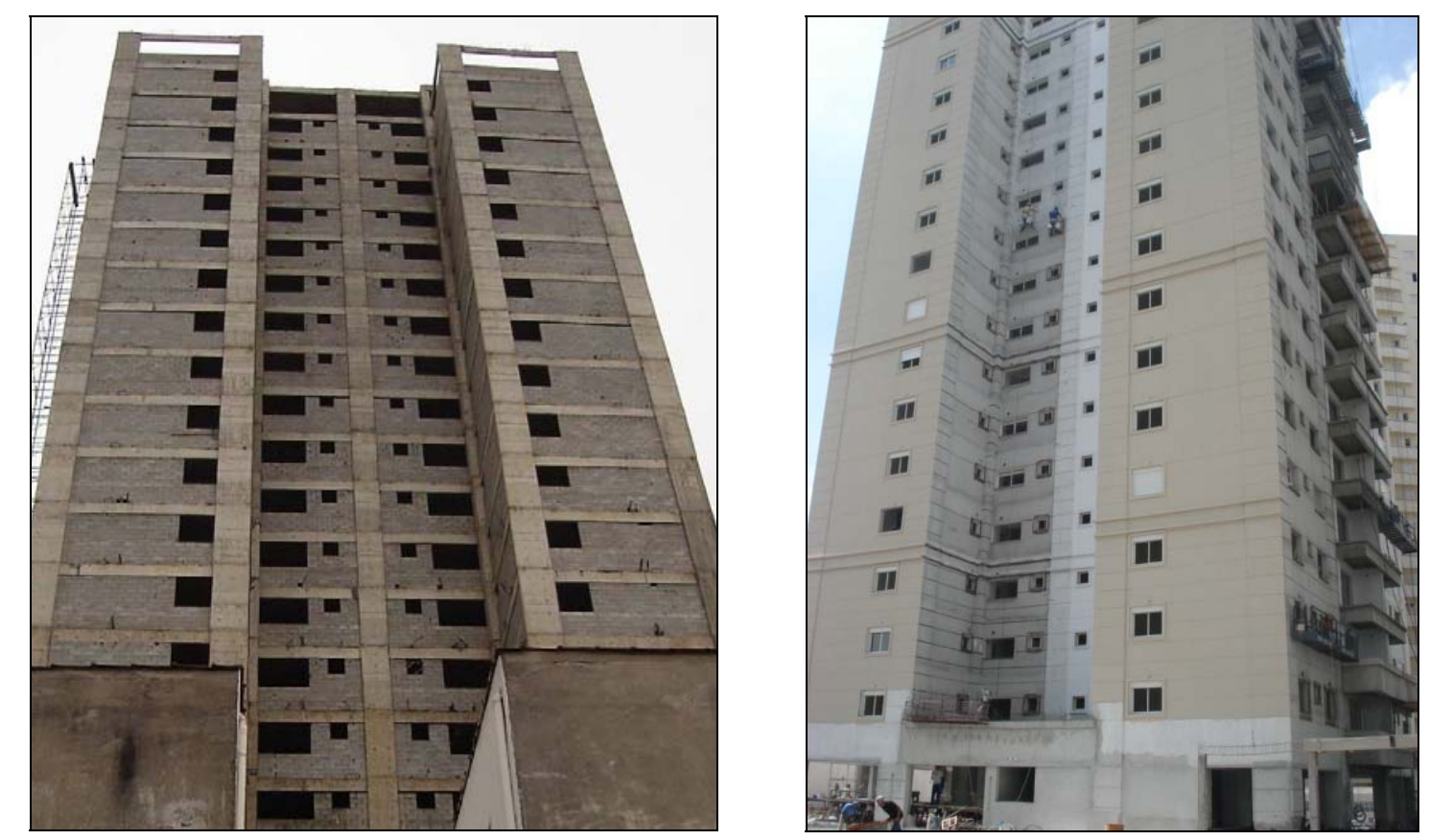

Figura 40 - Piazza San Pietro antes (esq.) e após a reabilitação (dir.) - arquivo do autor

A oportunidade de realizar um empreendimento de reabilitação surgiu a partir de um contato feito por um escritório de advocacia, especializado em solucionar litígios de empreendimentos não-concluídos e não-entregues por empresas construtoras, principalmente aqueles herdados da empresa Encol (categoria na qual 0 empreendimento Piazza San Pietro se enquadrava). Aproximadamente 12 anos se passaram desde o lançamento e as torres permaneciam abandonadas e 
degradadas, sem que nenhuma das 340 unidades tivesse sido entregue. Desse total, 160 já haviam sido comercializadas e, parte delas, já quitadas pelos proprietários.

Após o fechamento da Encol, os proprietários decidiram se organizar e planejar a retomada das obras. Quase a totalidade dos proprietários havia aderido ao movimento, exceto um deles, o IRB - Instituto de Resseguros do Brasil.

Em vista da situação judicial complicada na qual o empreendimento se encontrava e da estratégia inadequada do plano de conclusão das obras adotada pelos demais proprietários, o IRB, que adquiriu 74 unidades - todas localizadas em uma mesma torre -, optou por não aderir ao grupo e contratou os serviços do escritório de advocacia mencionado para buscar uma solução definitiva para o caso. Por indicação de outra construtora consultada, o escritório de advocacia chegou até a Tecnisa, que decidiu investigar a oportunidade (Figura 41).

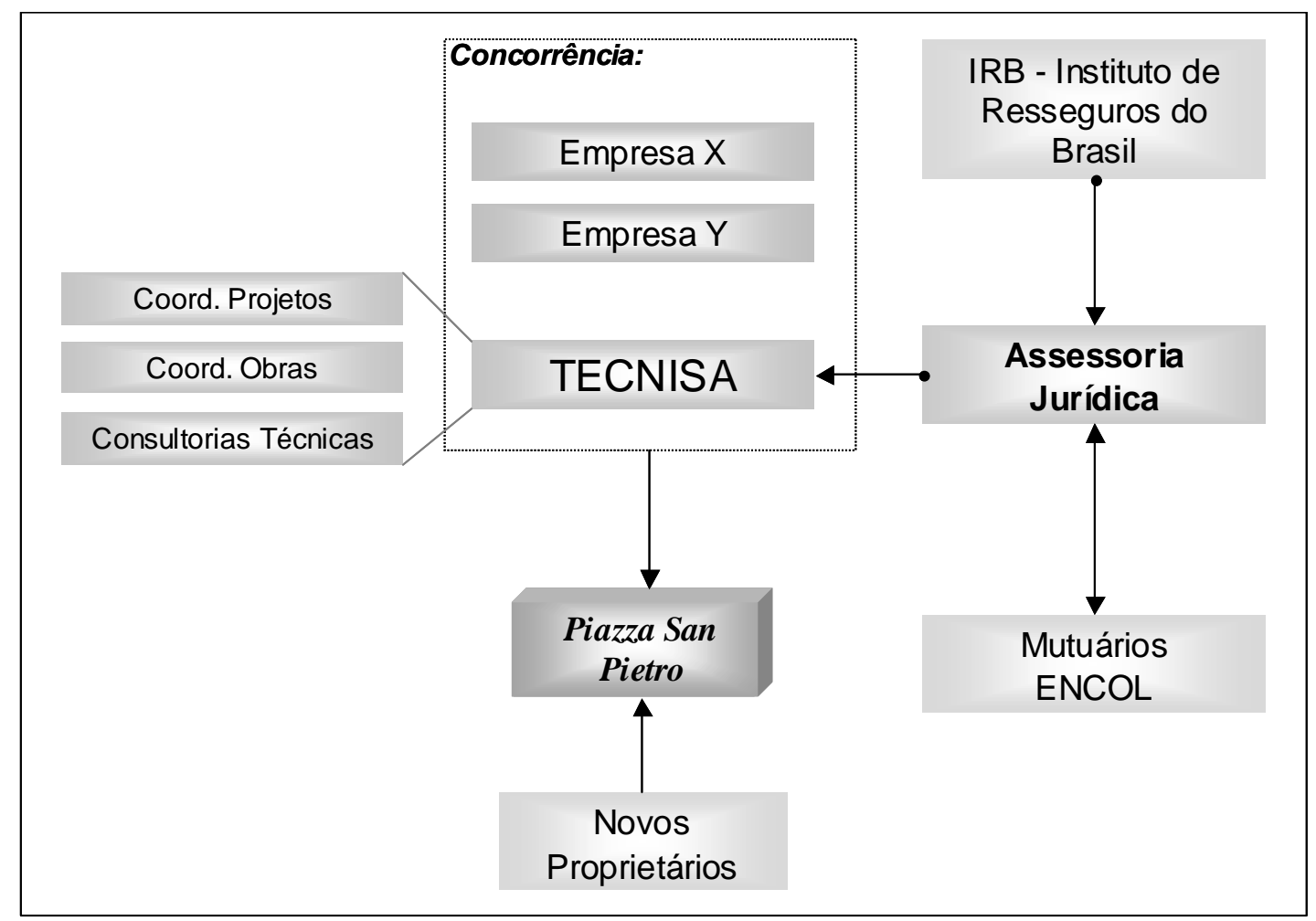

Figura 41 - Agentes envolvidos no início do empreendimento (dados coletados junto à Tecnisa) 


\subsubsection{Estudo de viabilidade}

Após analisar cuidadosamente as condições que cercavam o negócio e fazer uma leitura prévia dos pontos de vista técnico, comercial e jurídico, a Tecnisa aceitou ir adiante e iniciar o estudo de viabilidade. A primeira medida tomada foi a contratação de uma empresa de projetos de estrutura, especializada em recuperação estrutural.

Por se tratar de uma estrutura abandonada há anos e pelas condições da edificação, optou-se pela contratação de uma empresa que possuísse ampla experiência em recuperação de estruturas degradadas. No currículo da empresa contratada havia o projeto da recuperação estrutural do Edifício Joelma e de outro edifício, também incendiado, chamado Center 3, localizado na Avenida Paulista, ambos na cidade de São Paulo.

O foco principal desses trabalhos estava voltado para a verificação da resistência e da integridade das estruturas. Não houve, inicialmente, uma preocupação de verificar os projetos. Embora nesse momento a Tecnisa não detivesse os projetos de estruturas originais, o respeito pela capacidade técnica da Encol e de suas empresas projetistas parceiras levou a Tecnisa a não se preocupar, num primeiro momento, com o dimensionamento das estruturas e a concentrar esforços nas investigações in loco (Figura 42).
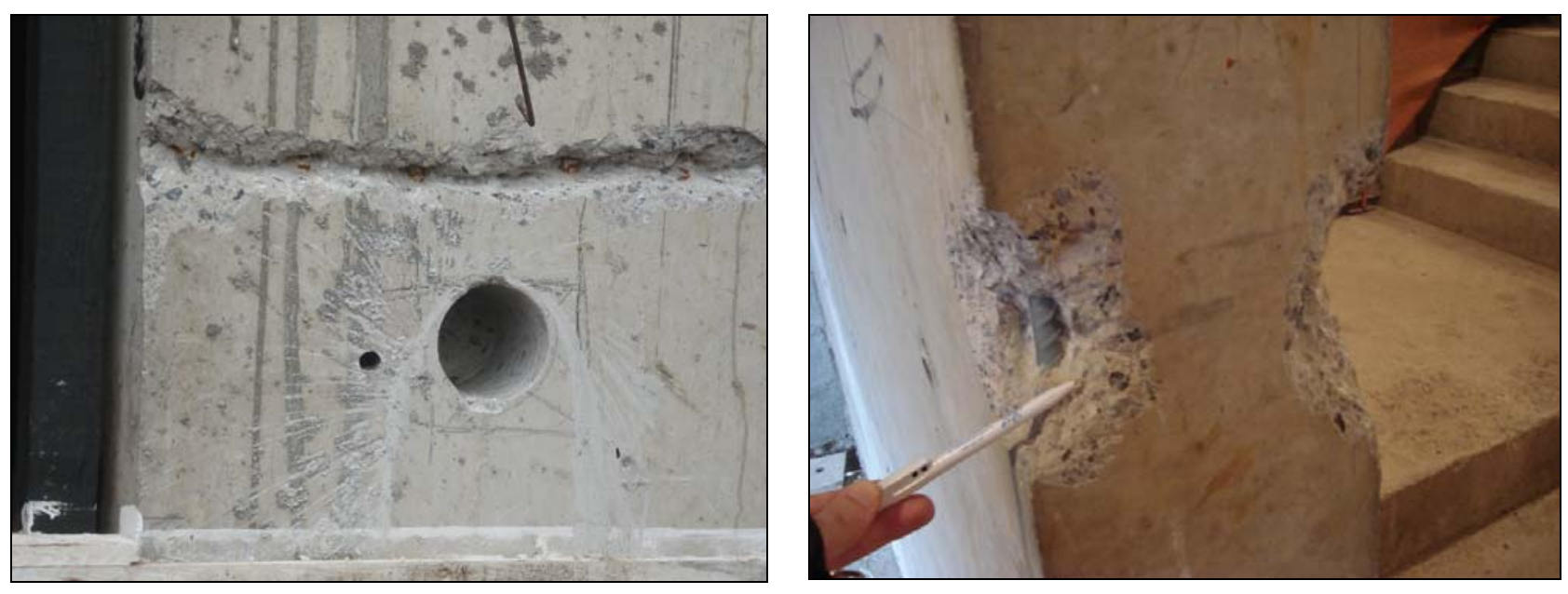

Figura 42 - Ensaios de resistência (esq.) e de integridade dos elementos estruturais (dir.): verificação do projeto não foi realizada na etapa de estudo de viabilidade (arquivo do autor) 
A gerência de projetos, envolvida no empreendimento desde o início, enviou especialistas das diversas disciplinas ao canteiro para uma análise prévia das condições das instalações existentes. Essas informações comporiam o estudo de viabilidade técnica e comercial. Após os resultados satisfatórios dos ensaios tecnológicos e das diversas inspeções realizadas, com o aval das áreas de projetos, obras, comercial, marketing, financeira e jurídica, pôde-se desenhar o plano de negócio para viabilizar a reabilitação do empreendimento (Figura 43).

A retomada das obras estava sendo gerenciada pelo escritório de advocacia e pelos proprietários. Foi definido que seria realizada uma concorrência entre três empresas construtoras, quando seria escolhida a melhor alternativa para o condomínio.

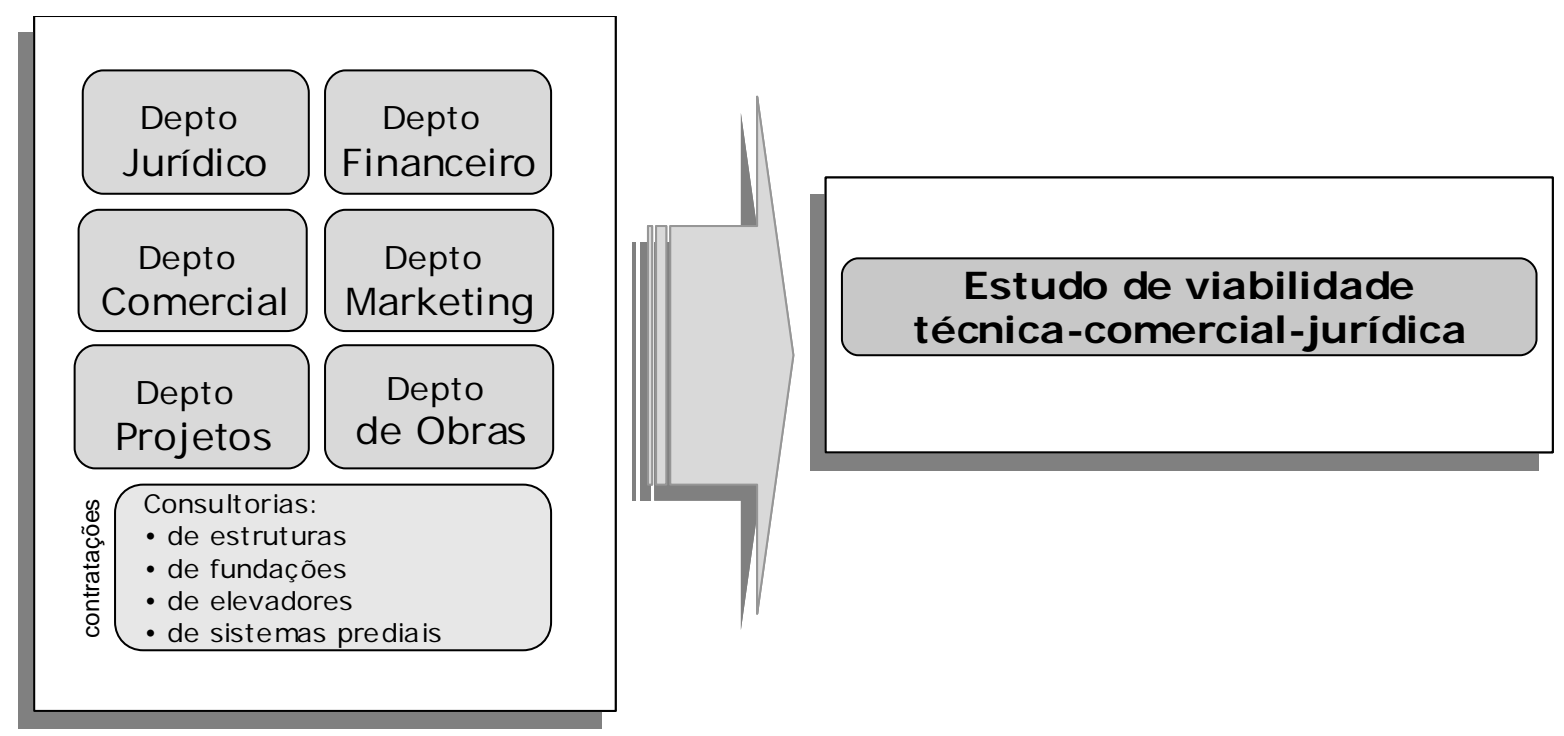

Figura 43 - Participação das diversas áreas da empresa para a elaboração do estudo de viabilidade (dados coletados junto à Tecnisa)

Uma das empresas convidadas para a concorrência havia sido contratada anteriormente, pelos mutuários, para a retomada das obras, entretanto, sem o planejamento, procedimentos e recursos adequados. Essa empresa também se especializou na retomada de empreendimentos abandonados pela Encol e atua na região de Jundiaí-SP através da parceria com pequenos escritórios de projetos e empreiteiros.

Entretanto, a retomada definitiva das 340 unidades necessitava de um plano de negócio estruturado, principalmente devido ao excessivo desgaste existente entre os 
envolvidos e o histórico do empreendimento. Os proprietários já haviam empenhado boa parte do investimento e os recursos não haviam sido aplicados, em sua totalidade, no empreendimento. Além do desequilíbrio econômico, o período de degradação natural das edificações se somava às tentativas fracassadas de retomada das obras.

O estudo de viabilidade elaborado pela Tecnisa resultou em uma proposta técnicocomercial apresentada e aceita pela associação dos mutuários.

\section{Aspectos legais}

Segundo o diretor técnico Fábio Villas Bôas, embora a Prefeitura do Município de São Paulo considere que os projetos do condomínio Piazza San Pietro foram aprovados na data do lançamento do empreendimento e, portanto, que a retomada das obras pudesse ser classificada como "prorrogação do início dos serviços", sem a necessidade de readequação às normas, a Tecnisa primou pela revisão e atualização de todos os projetos para o atendimento às normas e legislações vigentes. Em razão disso, as escadarias dos edifícios foram adaptadas para comportar o sistema de pressurização e as áreas de circulação e garagem foram adaptadas para permitirem o acesso de pessoas portadoras de necessidades especiais.

A pressurização das escadas foi um exemplo de modernização com grandes dificuldades técnicas. Não havia espaço para a instalação do sistema nas caixas de escada executadas. Após o estudo das alternativas técnicas, decidiu-se pela utilização do shaft embutido, no centro das escadarias, e a criação de uma casa de máquinas no subsolo.

Outro aspecto "não exigido por lei" para essa reabilitação, mas que foi seguido pela Tecnisa, foi a acessibilidade em todo o empreendimento. O projeto paisagístico foi totalmente adaptado à realidade da acessibilidade, mesmo implicando em adaptações nos projetos de estrutura e na supressão de vagas na garagem para a criação de rampas de acesso no pavimento térreo. 
De uma forma geral, a empresa avaliou que o poder público se mostrou interessado em que o empreendimento fosse definitivamente entregue e, portanto, não criou empecilhos à execução dos serviços que atendiam às normas e boas práticas.

A preocupação pela preservação da identidade e do respeito adquiridos pela empresa, junto aos seus clientes foi potencializada, uma vez que o estigma de abandono que o empreendimento herdou não poderia comprometer, nesse momento, o sucesso do relançamento. Além disso, havia ainda 180 unidades a serem comercializadas, o que representava a possibilidade de novos proprietários, com toda a série de exigências usuais relacionadas a um novo imóvel.

\subsubsection{Caracterização do empreendimento}

Os projetos originais foram resgatados em sua grande parte, conforme informou a gerente de projetos da Tecnisa, arquiteta Patrícia de Campos Valadares. Os "últimos dias" da Encol deixaram marcas profundas em algumas empresas projetistas. Talvez tenha sido esse o motivo de algumas delas terem se afastado do empreendimento. Mesmo assim, foi possível contatar os projetistas para a coleta de dados e projetos.

Cercada de empresas parceiras, decididas a enfrentar o desafio, a coordenação de projetos, que acompanhava o empreendimento desde o início, concentrou esforços nas atividades de projeto. Para isso, uma vez que o empreendimento entrou em operação, a ferramenta de comunicação tipo extranet para dados de projetos entrou em funcionamento.

Devido às sucessivas paralisações (Figura 44) e ao longo tempo de obras em ritmo lento, os arredores do terreno se tornaram degradados. A região possui grandes lotes vizinhos ao empreendimento onde se instalavam antigas fábricas. O cenário das torres abandonadas refletia o processo de degradação do entorno. Quando do início dos serviços, havia três torres com estrutura e alvenaria de vedação praticamente concluídas. A quarta torre estava na etapa de execução das primeiras lajes. 


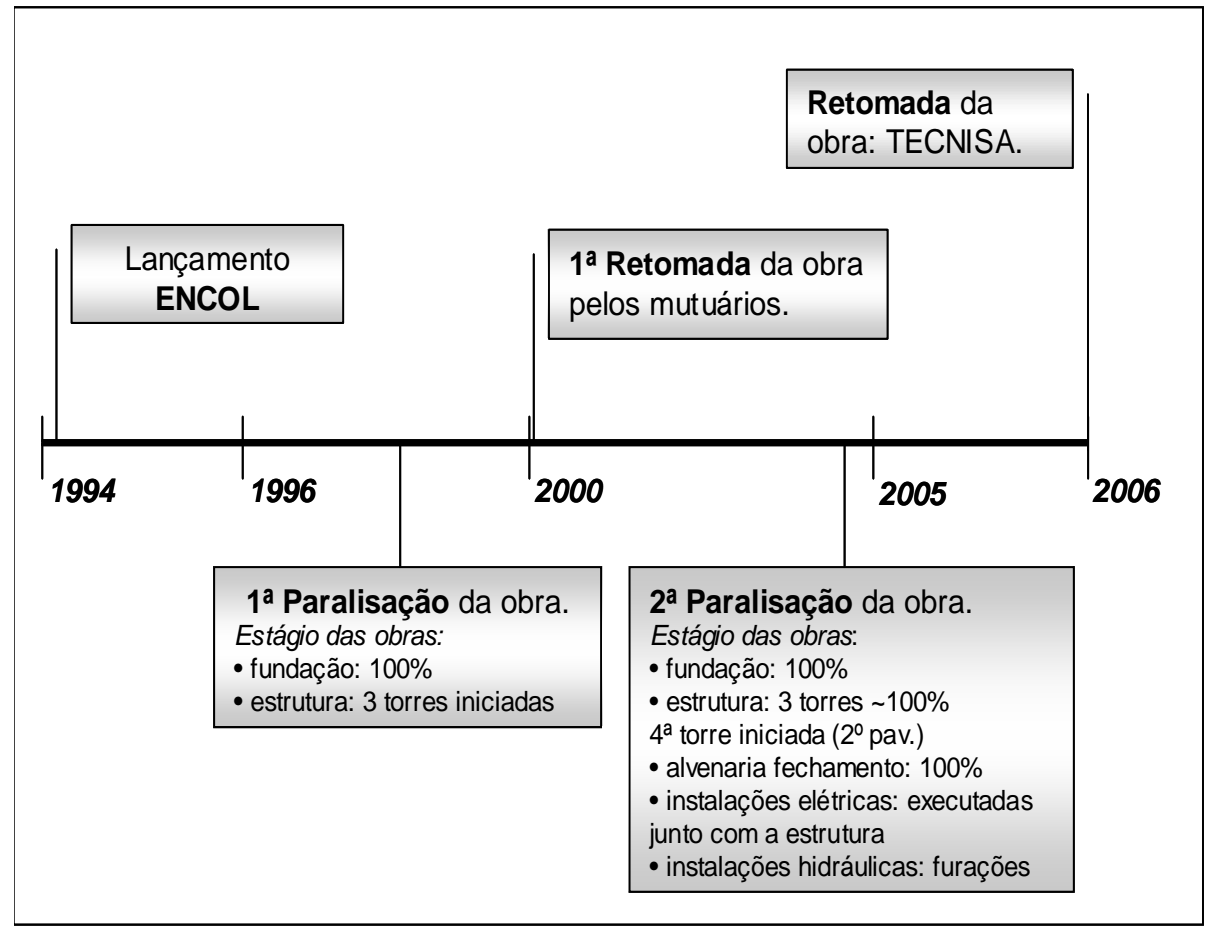

Figura 44 - Linha do tempo: paralisações e retomadas comprometem a padronização dos serviços e procedimentos (dados coletados junto à Tecnisa)

\subsubsection{Organização do empreendimento}

A empresa incorporadora e construtora, Tecnisa, optou pela formação de equipe interna de coordenadores de projetos. Essa estratégia, segundo a empresa, garante a velocidade dos empreendimentos e a identidade da empresa em cada projeto.

Na opinião da empresa, os empreendimentos de reabilitação demandam ainda mais eficiência e comprometimento da coordenação, e quando a coordenação de projetos é realizada dentro da empresa, pode-se ter maior controle do andamento dos serviços.

A equipe de coordenação da empresa está subordinada à gerência de projetos que, por sua vez, responde à diretoria técnica. Essa mesma diretoria é responsável pelas gerências de obras e desenvolvimento tecnológico. Dessa forma, acredita-se que a inteligência necessária para a melhoria dos procedimentos está concentrada e 
circula entre os agentes responsáveis. Essa integração pode ser necessária para o envolvimento da coordenação de projetos logo no início do empreendimento. Desde a escolha do terreno ou do edifício a reabilitar, a participação da gerência de projetos é requisitada.

Geralmente, em projetos de reabilitação, as áreas de projetos dependem das informações coletadas no campo para desenvolver suas atividades. Além disso, as restrições de projeto são apresentadas pela estrutura existente e precisam ser auferidas pela equipe de campo.

A seleção das equipes de projeto e obra seria fundamental para o sucesso do empreendimento. Segundo Villas Bôas, foi destacado o engenheiro residente mais experiente da empresa, com 15 anos de Tecnisa e temperamento calmo, para esse desafio. Já era esperado todo tipo de dificuldades no canteiro e, portanto, seria fundamental que o engenheiro residente pudesse proporcionar estabilidade no ambiente de trabalho.

\subsubsection{Estado geral da edificação}

Dentre as medidas tomadas pela Tecnisa quando do início dos serviços, uma equipe de obra foi designada para efetuar todo tipo de levantamento de campo, em todos os pavimentos das quatro torres, para dar suporte à elaboração dos projetos.

Foram feitos os seguintes levantamentos de campo:

- mapeamento das medidas reais entre elementos estruturais: pilares, vigas e lajes;

- levantamento das cotas de piso em todos os ambientes dos pavimentos;

- verificação do alinhamento das alvenarias de vedação das fachadas e das vigas da varanda;

- inspeção nas amarrações das alvenarias de fachadas e internas;

- verificação da integridade de todos os eletrodutos embutidos; 
- verificação do alinhamento dos pontos de furações no piso para instalações elétricas com as alvenarias dos andares subseqüentes;

- compatibilização das furações para passagem de tubulações hidráulicas;

- verificação de parte das armaduras de pilares e vigas;

- mapeamento das falhas de concretagem nos elementos estruturais.

Nas fachadas, em virtude da precariedade das amarrações entre os panos de alvenaria e o desaprumo acentuado, em todo o fechamento externo das quatro torres, os serviços foram condenados à demolição completa. Outros fatores que contribuíram para essa tomada de decisão foram: as janelas possuírem alturas variáveis e a utilização de vergas nas janelas. A Tecnisa adota, sempre que possível, o padrão de janelas fixadas no fundo das vigas de borda.

Como o levantamento dos elementos estruturais de fachada estava sendo dificultado pela grande irregularidade das alvenarias de fechamento, o mesmo foi executado após a definição da demolição de $100 \%$ das alvenarias, quando se descobriu que as vigas das varandas também apresentavam desalinhamento significativo.

As áreas de projetos e obras precisavam decidir o que fazer com o material da demolição das alvenarias de fechamentos. O departamento de desenvolvimento tecnológico estudou a alternativa de aproveitar o material na fabricação de argamassa como agregado miúdo, mas após consulta a especialista, a hipótese foi descartada. Segundo orientação do consultor contratado, o alto fator de correção que deveria ser aplicado ao material inviabilizaria a estratégia.

Outra alternativa era a remoção para bota-fora, mas o custo do transporte era elevado devido ao grande volume. Decidiu-se, então, utilizar o material como subbase do piso do subsolo. O material foi espalhado e adensado com compactador, tipo rolo de carneiro, como ilustrado na Figura 45. 


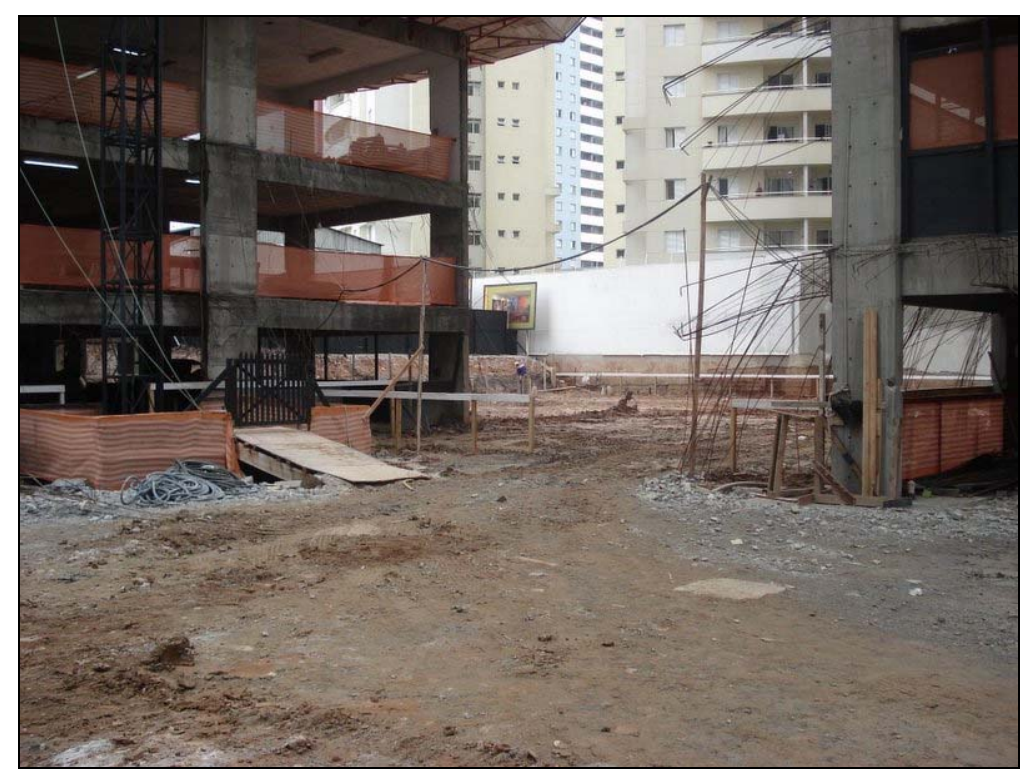

Figura 45 - Resíduo de demolição das alvenarias de vedação externas compactado e utilizado como sub-base para o piso da garagem (arquivo do autor)

Embora os ensaios tecnológicos realizados para o estudo de viabilidade tenham apresentado resultados satisfatórios quanto à resistência e integridade dos materiais aplicados na estrutura, o volume de incidência de não-conformidades dimensionais identificado surpreendeu a equipe técnica da empresa. A equipe de campo identificou excentricidades de pilares da ordem de $14 \mathrm{~cm}$. As recorrentes excentricidades dos pilares resultaram em ambientes com medidas diferentes de um pavimento para o outro, o que dificultaria sobremaneira as atividades de projeto.

\subsubsection{O processo de projeto}

\subsubsection{LEVANTAMENTOS DE CAMPO}

Desde o início do empreendimento foi identificada a necessidade de que os departamentos de projeto e obra da empresa trabalhassem em conjunto. Embora tradicionalmente essas áreas tenham um fluxo de informação bastante eficaz, o empreendimento exigiu um contato mais frequente e direto entre as partes, conforme ilustra a figura 46. Os dados coletados na obra eram transformados em croquis e 
enviados por fax para a área de projetos, que desenvolvia uma solução para o problema.

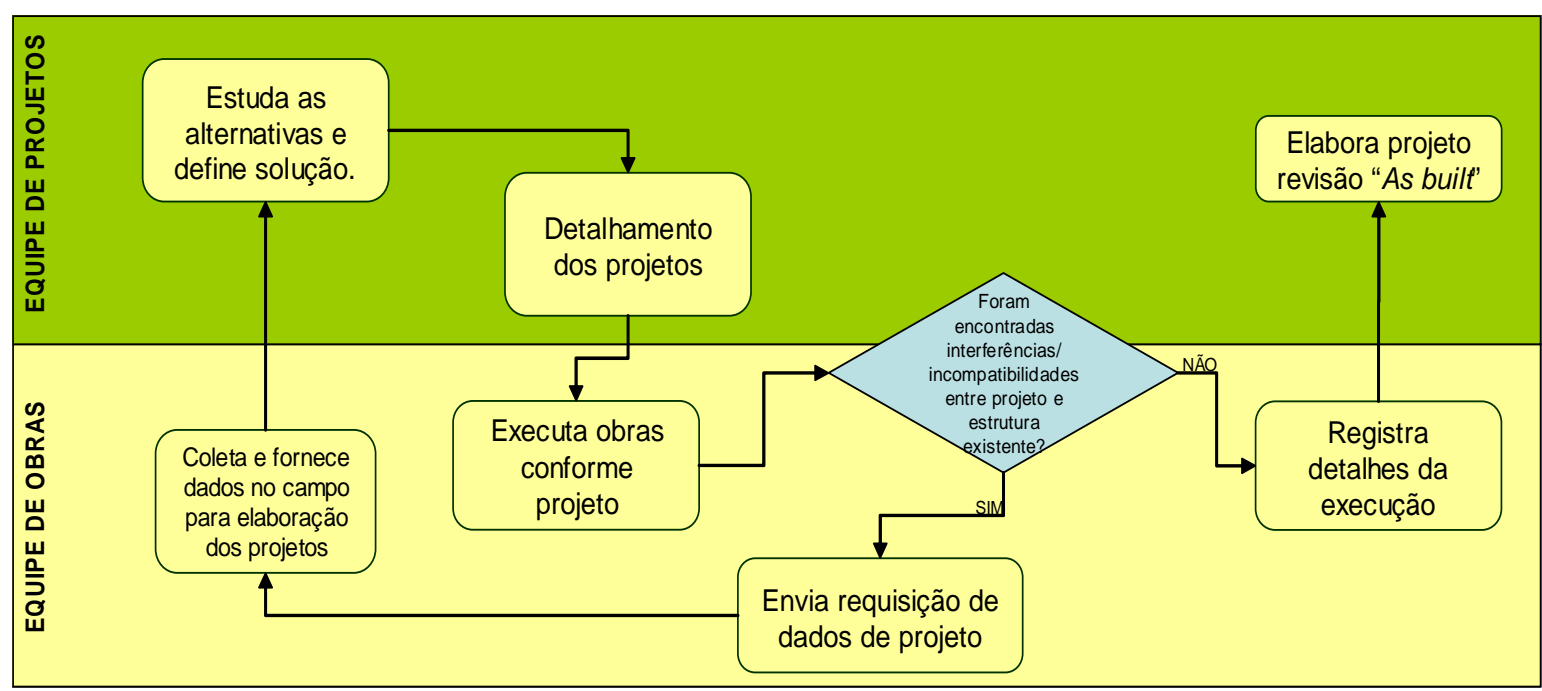

Figura 46 - Fluxo de informações: interdependência entre as áreas de projeto e obra (dados coletados junto à Tecnisa)

A falta de padronização foi um grande desafio para a área de projetos da empresa, que sempre esteve acostumada a projetar novos edifícios. Entretanto, o desafio maior identificado pela área de projetos foi dar seqüência a uma edificação iniciada por empresa com cultura, padrão de qualidade, sistemas construtivos, acompanhamento tecnológico, processos de projeto etc. diferentes do padrão utilizado pela Tecnisa.

\subsubsection{DESENVOLVIMENTO E FORMALIZAÇÃO DO PRODUTO}

O desenvolvimento do produto exigiu dos projetistas um desempenho ainda mais notável. O projeto original representava a demanda do público de 15 anos atrás, e caberia aos projetistas atualizar o produto e torná-lo comercialmente atrativo.

Outro aspecto que precisaria ser trabalhado pela área de projetos era o fato de se tratar de um empreendimento abandonado por tanto tempo e degradado. $O$ preconceito do público precisaria ser revertido, principalmente o da vizinhança que, 
por anos, conviveu com a estrutura inacabada que contribuía para a degradação do arredor e que, agora, eram vistos pela empresa como eventual público alvo das unidades não comercializadas. Para isso, a empresa fez a documentação fotográfica das atividades de recuperação das estruturas e disponibilizou-as em um painel no canteiro de obras, como ilustra a Figura 47.
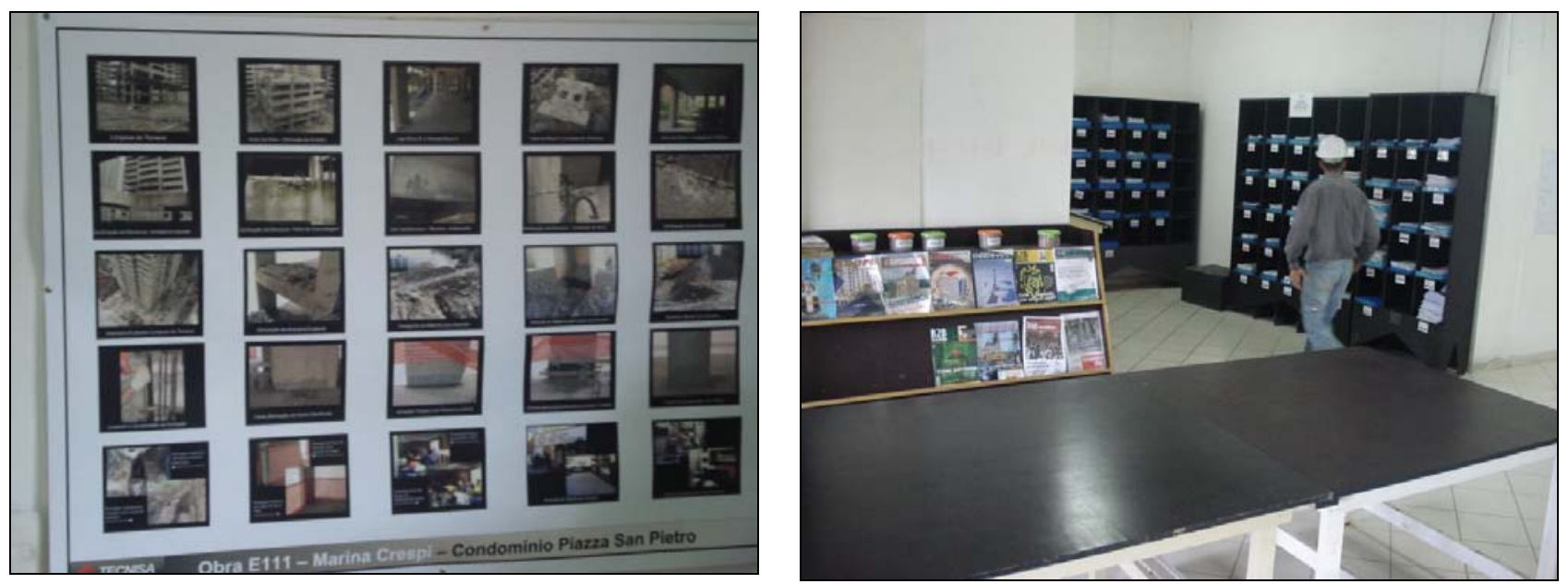

Figura 47 - Painel com fotos dos serviços de recuperação estrutural: mudança de imagem do empreendimento no canteiro de obras da construtora (arquivo do autor)

O desafio comercial esteve sempre limitado às possibilidades técnicas impostas pela estrutura existente. Os projetistas tinham de conviver com o fato de que nem tudo era possível de ser realizado. A estrutura construída impunha limites às alternativas clássicas como, por exemplo, a área reduzida de varanda dos apartamentos que, segundo a empresa, é uma das exigências atuais do mercado imobiliário de São Paulo.

Sucedeu-se a etapa de contratação de arquitetos para o desenvolvimento dos projetos. A escolha dos projetistas foi uma etapa cuidadosamente planejada pela empresa. Sabia-se que o empreendimento não poderia ser conduzido como outro qualquer. Não poderia ser dispendida a mesma atenção que se dá a empreendimentos convencionais ou "novos". Os projetistas escolhidos precisariam sentir-se desafiados a transformar aquela estrutura abandonada em um produto moderno e, principalmente, com a identidade da empresa incorporada, assim como os demais produtos. 
Dentre as empresas de projetos parceiras da Tecnisa, poucas tinham experiência em reabilitação. Entretanto, o peso desse fator, na seleção das empresas e profissionais, era relativo à disciplina de projeto. Os projetos complementares foram contratados com empresas especializadas não parceiras da Tecnisa. Entretanto, mesmo sem experiência nesse tipo de empreendimento, quando a empresa se sentia confortável e desafiada com a proposta apresentada, foi considerada na seleção.

A forma de remuneração pelos projetos foi definida caso a caso. Naturalmente, não puderam ser aplicadas as mesmas condições praticadas nos outros empreendimentos da empresa, uma vez que a dedicação e os produtos entregues eram diferentes.

Em paralelo, aconteciam os levantamentos de campo que seriam fundamentais para as primeiras atividades de projeto. A elaboração do material de publicidade para o relançamento do empreendimento dependia dos levantamentos de campo, que eram realizados diariamente no canteiro pela equipe de obras. Atualmente, as incorporadoras estão cada vez mais preocupadas em atender minuciosamente às especificações apresentadas aos proprietários no momento da compra dos imóveis.

Os consumidores estão cada vez mais exigentes e procuram se respaldar, de todas as maneiras possíveis, para atender às especificações apresentadas pelas incorporadoras no estande de vendas. É muito comum se utilizarem de câmeras fotográficas e filmadoras (algumas delas acopladas a celulares) para registrarem as ilustrações, maquetes etc. apresentadas pelos corretores. Posteriormente, todos os detalhes apresentados serão exigidos na entrega do imóvel.

Essa preocupação se tornou mais relevante para a equipe de projetos, nesse empreendimento, devido ao fato de que se tratava de uma estrutura já construída, que apresentava irregularidades e falta de padronização generalizada das construções. Surgiram então os questionamentos: "com o que vamos nos comprometer (com os clientes)? onde está a medida média (dos ambientes)? como faço uma planta (modelo) e defino as cotas?" relembra a arqta. Patrícia Valadares 
sobre as questões levantadas durante a elaboração do material de publicidade do empreendimento.

Ao passo que as equipes de campo encaminhavam as informações coletadas, os projetos eram desenvolvidos. Embora os projetos executivos tivessem sido resgatados, não foi possível utilizá-los,devido à incompatibilidade apresentada entre o desenho e o executado. A equipe de topografia teve então que documentar toda a estrutura existente, pavimento por pavimento, ambiente por ambiente.

Em seguida, na constatação da equipe de projetos, o "projeto-tipo" só poderia ser criado a partir da sobreposição de todas as medidas dos ambientes levantadas no campo. Uma vez definidas as cotas médias, foi verificado se todos os ambientes possuíam medidas adequadas para utilização. Pelo fato das dimensões atenderem aos padrões antigos de projetos, não houve reprovação em nenhum ambiente e o padrão "tipo médio" pôde ser adotado. Ou seja, nenhum ambiente das unidades habitacionais ficou com medidas menores do que o permitido.

Com base no "projeto-tipo" com medidas "médias", foi desenvolvido o projeto para produção de alvenarias internas de vedação. Entretanto, ao contrário do que se pratica para empreendimentos convencionais, não foi possível o detalhamento preciso das fiadas e amarrações. Como cada parede de cada ambiente se comportava de uma maneira, a solução apresentada pela empresa projetista foi definir alternativas para as diferentes medidas que poderiam ser encontradas no momento da execução. Portanto, a solução deveria ser definida no campo.

No tocante aos projetos de sistemas prediais, a decisão foi bastante peculiar, fugindo do padrão de contratações da empresa. A prática interna não prevê a contratação de projetistas de sistemas prediais ligados a empresas chamadas "instaladoras", com o propósito de promover uma análise crítica mais profunda e isenta entre as atividades de ambos.

Entretanto, no caso de Piazza San Pietro, a melhor estratégia apontou para um sentido inverso. Devido às características da obra e a sua complexidade, do ponto de vista de gestão da produção, as decisões de projeto demandariam uma 
velocidade tamanha, para não comprometer o andamento dos serviços no campo, que apenas duas empresas (projetista e instaladora) parceiras poderiam imprimir. A arqta. Patrícia Valadares reforça: "é bom que a equipe de projetistas seja uma equipe integrada com a execução da obra". Assim, decidiu-se contratar empresas projetistas indicadas pela empresa instaladora.

\subsubsection{DETALHAMENTO DO PRODUTO}

A etapa de definição do produto proporcionou à empresa uma experiência até então não vivenciada. Além de desenvolver um produto novo e contemporâneo, dentro das limitações impostas pela estrutura existente, esse produto deveria agradar aos proprietários mutuários da Encol. Eles foram envolvidos nas definições e a equipe de projetos teve que lidar com mais esse agente. Da mesma forma, as alterações de projeto deveriam ser aprovadas pelos proprietários. Essa situação atípica pôde ser bem administrada e o produto final teve ampla aprovação e aceitação entre os proprietários. A expectativa dos mutuários foi superada ao conhecerem a proposta de projeto apresentada pela Tecnisa.

A necessidade de tornar o projeto contemporâneo foi apresentada aos projetistas como prioridade para viabilizar a sua comercialização. A proposta do projeto original das edificações não atenderia às necessidades atuais dos moradores. As áreas de lazer, originalmente localizadas no centro das quatro edificações, foram deslocadas para os cantos do terreno. No seu lugar foi projetada a praça central. Segundo a arqta. Patrícia Valadares, os projetos de edifícios residenciais modernos priorizam as áreas de convívio social e é necessário destinar um local isolado para as áreas de lazer, principalmente o local da piscina. O acesso de visitantes não deve passar pelas áreas da piscina, de maneira a garantir a privacidade dos usuários. Além da implantação, o projeto da piscina foi totalmente modificado. Foram criadas raias de $25 \mathrm{~m}$ na piscina, de modo a agregar funcionalidade além do simples banho.

$\mathrm{Na}$ avaliação da Tecnisa, esse empreendimento se destacou, entre os demais lançamentos, pela generosidade dos espaços internos e áreas comuns das 
edificações. Com áreas privativas de $84 \mathrm{~m}^{2}, 104 \mathrm{~m}^{2}$ e $125 \mathrm{~m}^{2}$ as dimensões dos ambientes internos surpreenderam toda a equipe envolvida no empreendimento, assim como surpreende os clientes que visitam os imóveis.

O empreendimento provocou um estudo da relação custo $\mathrm{x}$ benefício de criar ambientes mais amplos. Os resultados foram satisfatórios e, segundo Villas Bôas, essa deverá ser a tendência dos próximos empreendimentos da empresa.

A dimensão do terreno (área total: 9.549,54 $\mathrm{m}^{2}$ ) e as múltiplas possibilidades de criação de áreas de lazer e convívio social constituíram-se em outros aspectos positivos, os quais despertaram atenção especial para o empreendimento. Na opinião da arqta. Patrícia Valadares, a cidade vive um momento de crescente escassez de terrenos disponíveis para novos lançamentos. Havia uma grande preocupação da equipe de projetos no sentido de preservar o padrão Tecnisa de qualidade e conceito dos projetos, uma vez que o projeto original não proporcionava condições adequadas para isso.

Embora todo o empreendimento estivesse passando pelo processo de reabilitação, o projeto do apartamento em si não necessitou de alterações. Do ponto de vista de utilização dos espaços, a empresa julgou o projeto adequado e com o diferencial de ter ambientes amplos.

Os "apartamentos decorados", que atualmente estão presentes em todos os estandes de venda de imóveis, são considerados, pela Tecnisa, como o primeiro ponto de validação dos projetos. Nesse momento, as soluções são colocadas à prova. É a oportunidade de testar, em escala real, o que foi projetado. No caso de empreendimentos de reabilitação, essa possibilidade está disponível desde o primeiro momento do empreendimento. Como a construção está executada, os projetos podem ser construídos sob medida, tomando como base o apartamento modelo.

\section{* Áreas comuns externas}


No que tange às áreas comuns externas do empreendimento, o projeto original apresentava um conceito diametralmente diferente da proposta de reabilitação apresentada pela Tecnisa.

Segundo a arqta. Patrícia Valadares, devido às sucessivas ondas de violência na cidade de São Paulo nos últimos anos, os projetos modernos passaram a incorporar as áreas de lazer dentro do próprio condomínio e a utilizar os espaços comuns com áreas de serviços e recreação.

A fase dos projetos que oferecem serviços de TV a cabo, internet coletiva etc. está superada e isso não é mais um diferencial de mercado. Atualmente, os consumidores das grandes cidades buscam tranqüilidade e momentos de relaxamento no ambiente residencial. Talvez tenha sido por esse motivo que o impacto dos mutuários da Encol foi tão grande ao se depararem com a proposta de projeto da Tecnisa.

Originalmente, as torres apresentavam pilotis no pavimento térreo, com um pequeno hall de entrada. A área aberta não proporcionava nenhuma utilização de lazer específica. Havia sido projetada uma piscina, localizada no centro das torres, e uma quadra poliesportiva. Além disso, cada torre possuía um salão de festas independente. Se o projeto original oferecia apenas 4 utilizações da área de lazer (piscina, quadra poliesportiva, salão de festa e área para caminhadas), a proposta de reabilitação ofereceu 30 novos usos apresentados na Tabela 17. 
Tabela 17 - Mudanças de uso nas áreas externas do condomínio: 30 novos espaços de lazer e recreação (dados coletados junto à Tecnisa)

\begin{tabular}{ll}
\hline 1. Salão de cabeleireiro & 16. Piscina infantil \\
\hline 2. Pet care & 17. Piscina adulta com biriball e raia de $25 \mathrm{~m}$. \\
\hline 3. Play ground com brinquedos pequenos & 18. Bar \\
\hline 4. Play ground com brinquedos grandes & 19. Sauna \\
\hline 5. “Campinho gramado" & 20. SPA urbano com ducha e ofurô \\
\hline 6. Churrasqueira com forno para pizza & 21. Sala de yôga \\
\hline 7. Bosque & 22. Sala de massagem \\
\hline 8. Praça central com espelho d'água & 23. Clube de experiências com sala de estar \\
\hline 9. Jardim japonês & 24. Salão de festas adulto com bar e cozinha \\
\hline 10. Deck para prática de alongamentos & 25. Sala de home teather \\
\hline 11. Rock center & 26. Salão de jogos \\
\hline 12. Salão de recreação infantil & 27. Salão de festas infantil \\
\hline 13. Cineminha & 28. Sala de ginástica \\
\hline 14. Vestiários masculino, feminino e infantil & 29. Depósito para sala de ginástica \\
\hline 15. Hall social decorado & 30. Quadra poliesportiva \\
\hline
\end{tabular}

\section{* Fachadas e áreas externas}

Atualmente, na Tecnisa, quase que a totalidade dos lançamentos acompanha o estilo arquitetônico "neoclássico" com molduras nas fachadas, amplas varandas que contornam o apartamento, guarda-corpos metálicos. O projeto de fachadas original considerava varandas estreitas com guarda-corpo em alvenaria e fachadas com detalhes diferentes do padrão neoclássico.

Em virtude dos problemas de desalinhamento da estrutura encontrados nas fachadas, os enchimentos necessários para esconder as irregularidades superavam os $3 \mathrm{~cm}$ toleráveis pela empresa. Assim, as molduras que compõem o padrão neoclássico desempenharam, além da função estética, a função técnica. Elas foram criadas de forma a interromper a seqüência de revestimento, criando seções nas fachadas. Dessa forma foi minimizado o impacto estético dos desalinhamentos causados pelo revestimento. 
- Estrutura e fundações

O mesmo consultor contratado para desenvolver o estudo de viabilidade técnica foi designado para coordenar os trabalhos de recuperação estrutural, com a ajuda de uma equipe de apoio formada por encarregados, pedreiros e ajudantes da Tecnisa.

Após verificar a integridade das estruturas e das fundações, na etapa de estudo de viabilidade do empreendimento, os dados coletados nos levantamentos de campo foram inseridos em um software de simulação estrutural e, então, se percebeu que as falhas de concretagem e a corrosão de armaduras não eram os únicos problemas que a estrutura apresentava. As simulações acusaram algo ainda mais grave: as estruturas não foram calculadas para suportar a ação dos ventos. Ou seja, a estrutura estaria subdimensionada e não atendia o estabelecido na Norma Brasileira NBR 6123. Ao serem analisados detalhadamente os projetos originais, constatou-se que não fora prevista a força da ação do vento como carga atuante na edificação. Portanto, a estrutura não estaria dimensionada para comportar-se adequadamente à ação do vento.

Nessa etapa, o empreendimento estava em plena execução e foi necessária agilidade para identificação de soluções de reforço das estruturas. A solução seria contraventar a estrutura da edificação, sendo, então, aventadas as seguintes alternativas de projetos:

- alternativa 1: execução de capa de complemento armado nas lajes;

- alternativa 2: criação de pilares na caixa de elevadores e escadarias e ancorar faixas de contrapiso armado nas lajes. Havia o problema da criação de ponte de aderência com a argamassa e corria-se o risco de ter baixa eficiência. Além disso, a espessura das faixas não seria constante, uma vez que o piso encontrava-se extremamente irregular;

- alternativa 3: execução de alvenaria estrutural em todo o perímetro da edificação, a fim de aumentar sua inércia. Essa opção provocaria o aumento de cargas nas fundações;

- alternativa 4: execução de viga invertida em todo o perímetro da edificação e criação de faixas de transferências pelo piso. 
A solução adotada foi uma combinação entre as alternativas 1, 2 e 4. Optou-se pela execução de vigas invertidas, em todo o perímetro; execução de contra-piso armado (que atenderia inclusive a demanda gerada nas instalações elétricas); e criação de pilares na caixa de escadaria, conforme ilustrado na Figura 48.

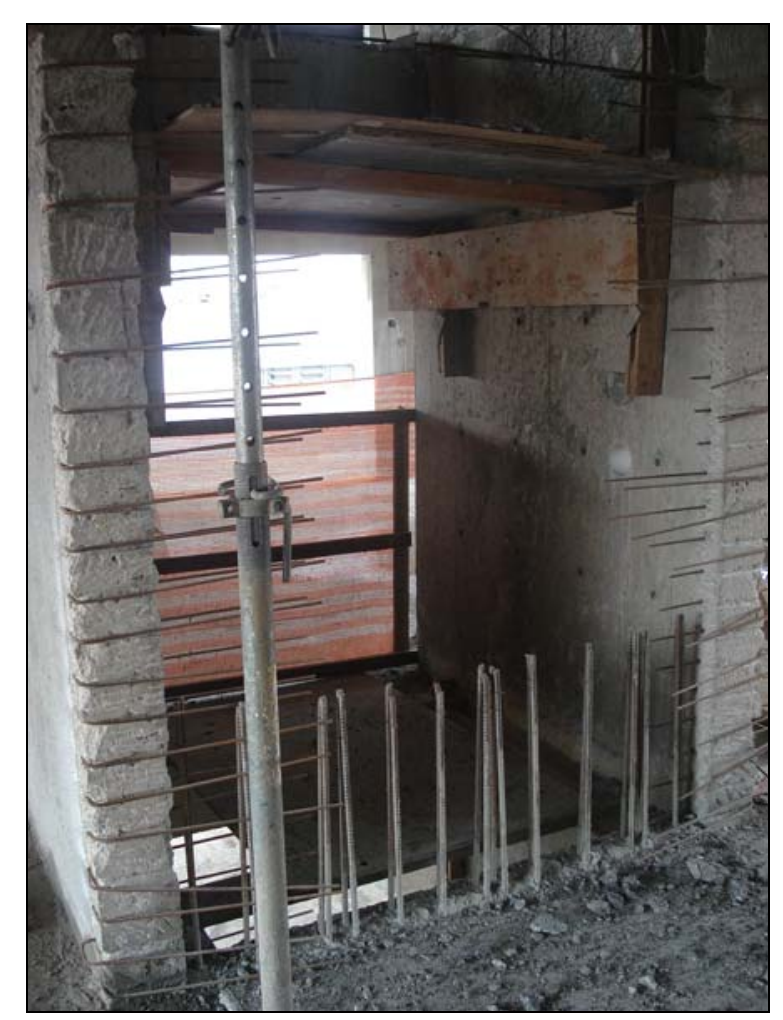

Figura 48 - Criação de pilar na caixa de escadaria para aumentar a inércia do conjunto (arquivo do autor)

Ao iniciar as atividades de complemento das vigas, percebeu-se que muitas delas não possuíam a quantidade e tipo de armadura adequados. Além disso, as seções das armaduras foram invertidas em parte dos pavimentos. Ou seja, as seções que deveriam ser utilizadas em um andar, foram utilizadas em outro andar. $O$ trabalho de reforço estrutural exigiu o emprego de armação com bitolas maiores em seções dos elementos estruturais, muitas vezes esbeltas (Figura 49). 


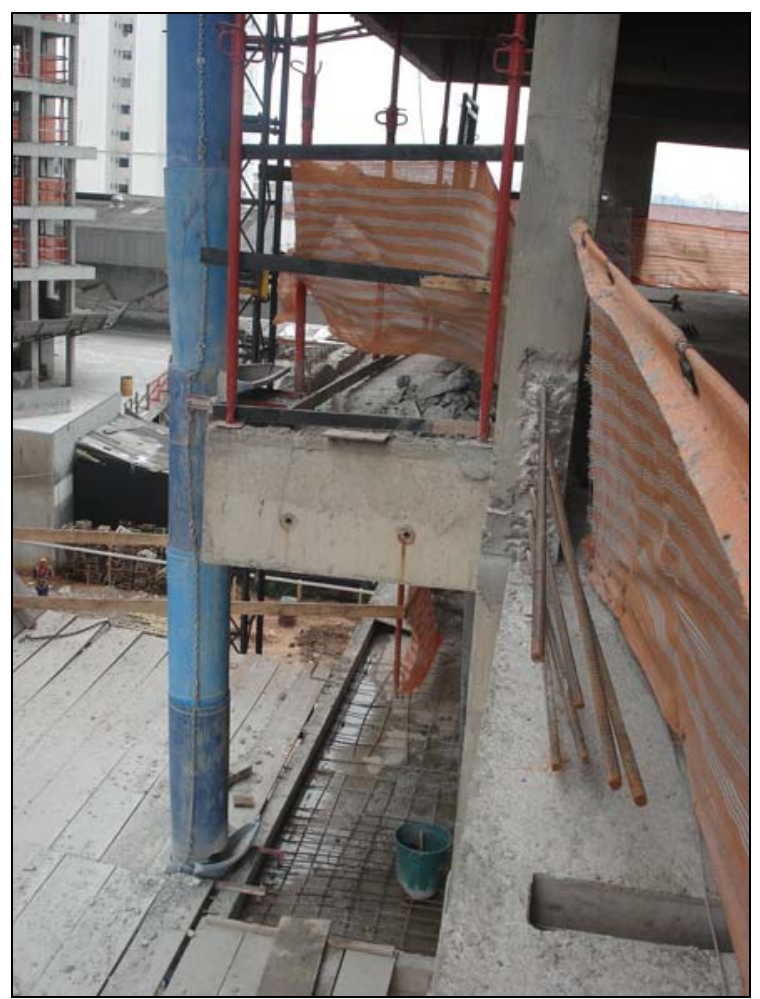

Figura 49 - Execução de reforço estrutural nas vigas de periferia e lajes dos pavimentos (arquivo do autor)

Por outro lado, o engrossamento da espessura das lajes (Figura 50) foi visto com bons olhos pela Tecnisa, que convive com reclamações de clientes quanto ao desconforto acústico provocado por lajes excessivamente esbeltas, além de deformações excessivas. O projeto original da Encol buscava a racionalização da produção e as lajes possuíam espessuras pequenas.

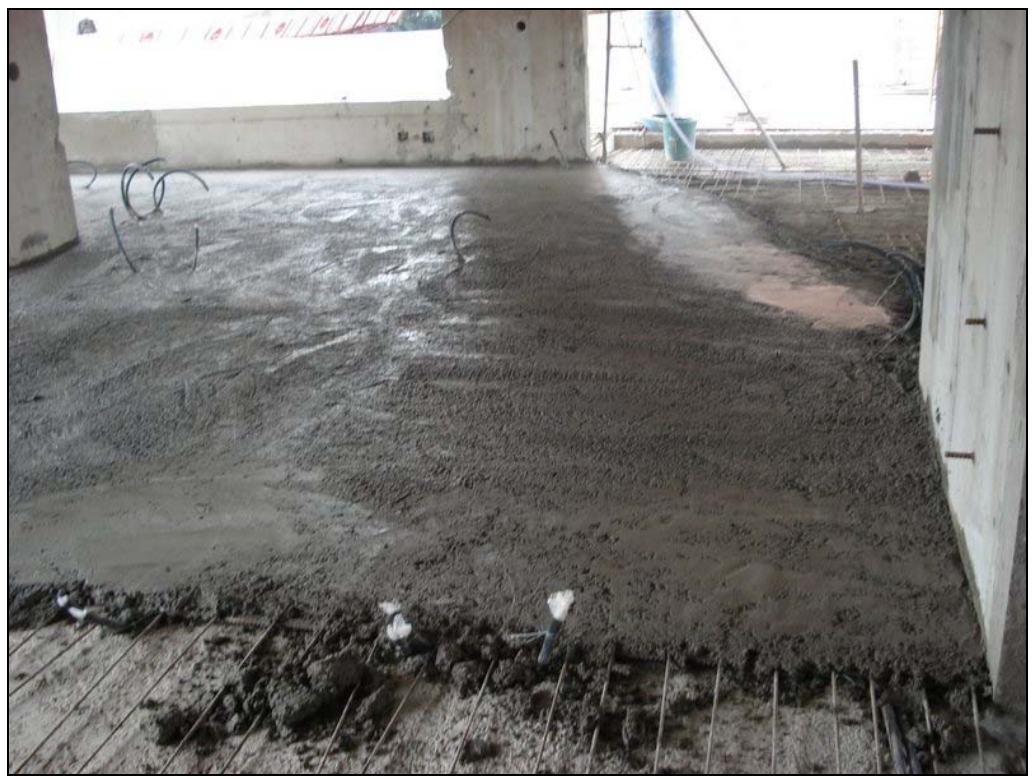

Figura 50 - Reforço estrutural nas lajes sendo executado: arquivo do autor) 
O projeto de fundação também sofreu alterações. Diferentemente das demais disciplinas de projeto, o consultor e projetista atual é o mesmo do projeto original. A empresa inspecionou as fundações e projetou, além dos reforços, 170 novas estacas para atender o novo projeto do pavimento térreo e subsolo.

No projeto original, as garagens de automóveis eram cobertas por uma estrutura leve, com telhas de fibrocimento. Em substituição a elas, foi projetada nova estrutura em concreto armado.

Os projetos das escadas não foram localizados. Nesse elemento encontrou-se outra grande surpresa. As alturas mínimas na escadaria não foram atendidas. Em todas as torres, os lances que servem os andares térreo, intermediário e primeiro apresentaram pé-direito irregular e que não atendiam aos padrões mínimos, impossibilitando até uma pessoa de média estatura de circular pelas escadas, conforme ilustra a Figura 51.

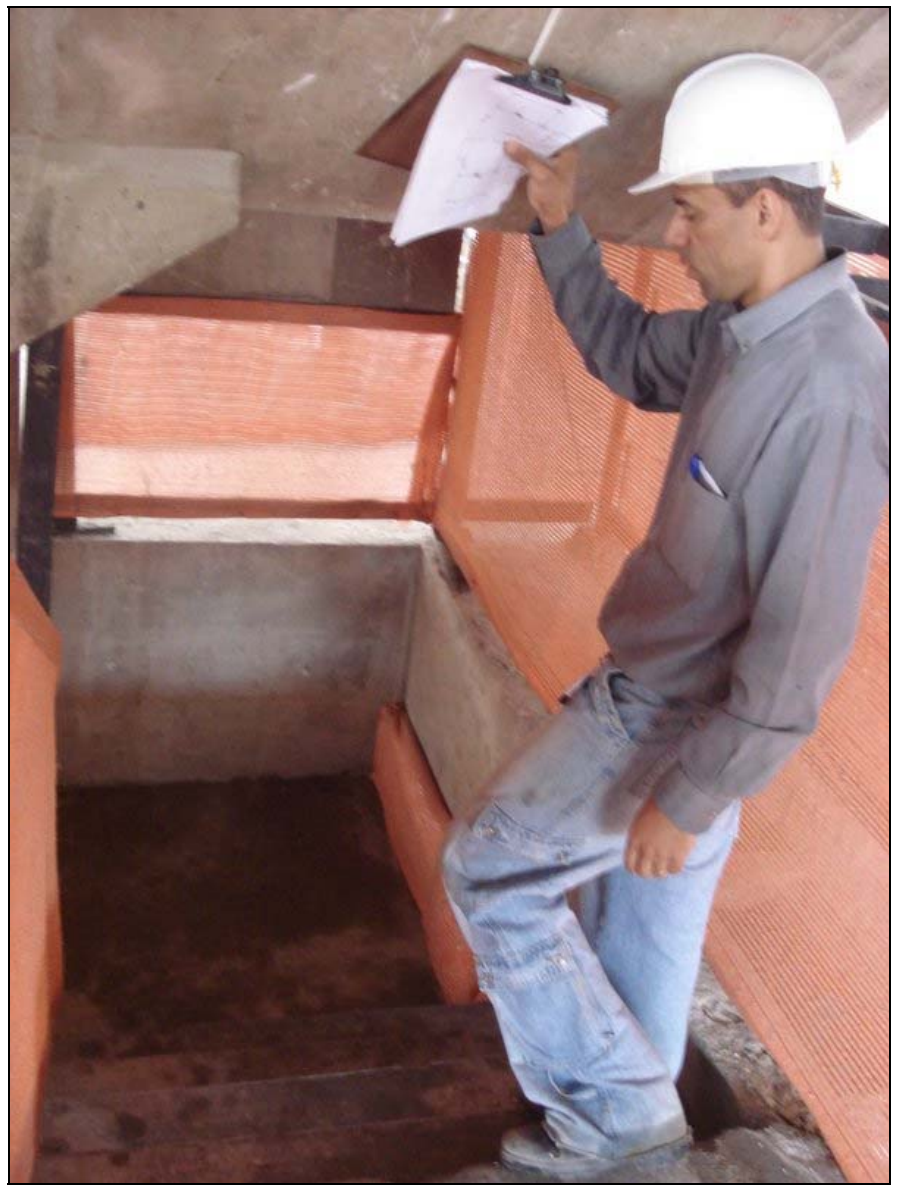

Figura 51 - Altura do pé-direito insuficiente em lances de escadaria (arquivo do autor) 
Isso exigiu novos serviços de demolição e construção não previstos no estudo de viabilidade. Em levantamentos de campo, lance a lance, as escadarias das quatro torres foram mapeadas e encaminhadas à área de projetos, para análise e tomada de decisão.

\section{* Sistemas Prediais}

As instalações hidro-sanitárias também precisaram ser adequadas para atendimento ao padrão da empresa. O projeto inicial previa a instalação do sistema PEX, que não faz parte da cultura da empresa, principalmente quando embutido em alvenaria de blocos. Como haviam sido executadas apenas as furações para passagem de tubulação (Figura 52), foi feito estudo de relocação dos pontos e o projeto foi modificado para tubulação e conexões de PVC e CPVC. O sistema de aquecimento elétrico de água nos chuveiros foi substituído por aquecimento a gás, com aquecedor de passagem individual. O projeto de instalações hidráulicas da Tecnisa ainda considera o sistema de medição individual de água das unidades habitacionais.

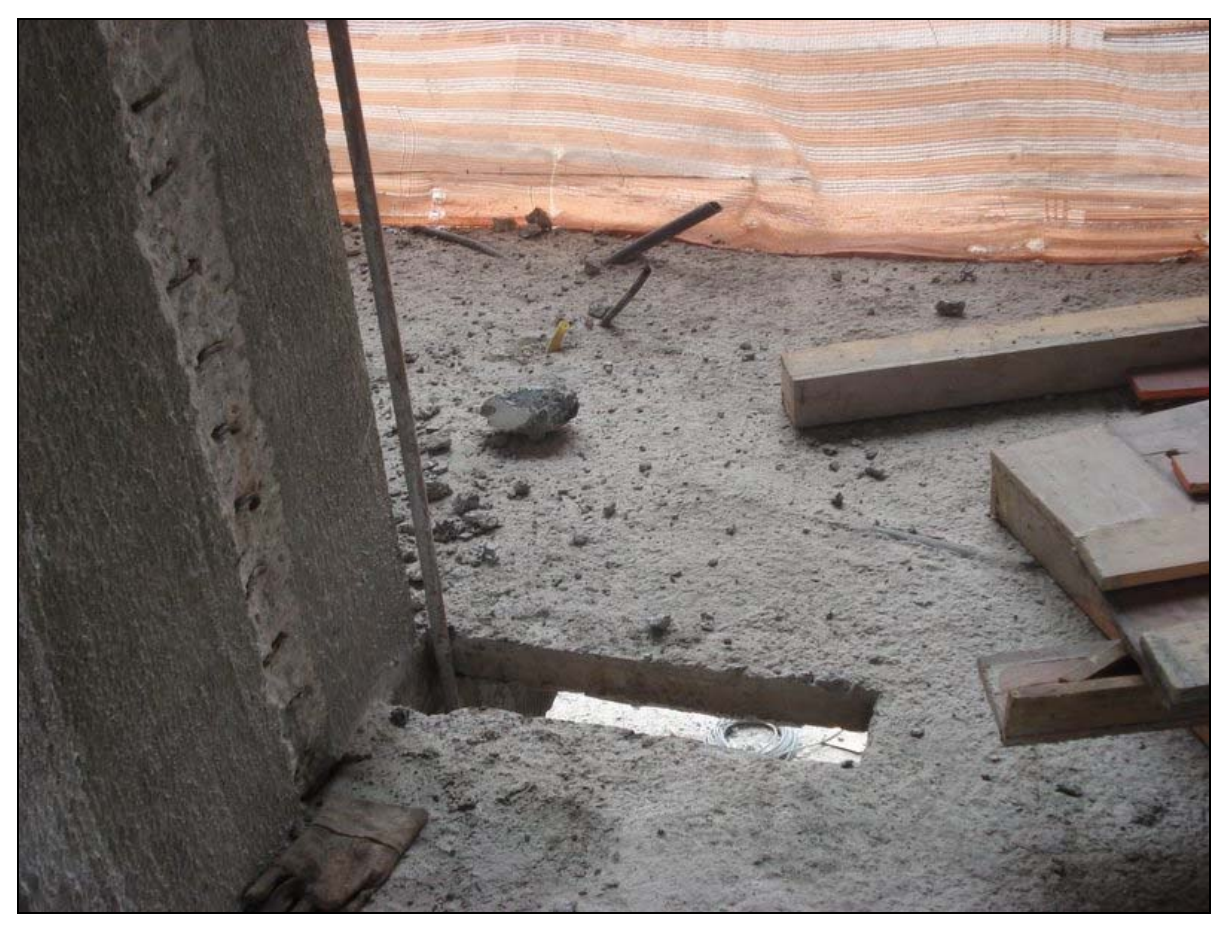

Figura 52 - Aberturas executadas na laje para passagem de tubulações do sistema PEX: o projeto de reabilitação especificou utilização de tubulações de CPVC e PVC (arquivo do autor) 
O projeto de instalações elétricas foi desenvolvido a partir da realidade encontrada na obra. É prática usual da Tecnisa a execução do projeto completo que contemple o lançamento de eletrodutos, que atenda a todas as opções de individualização dos apartamentos. Dessa forma, quando o proprietário opta por uma ou outra alternativa, a fiação é passada apenas nos eletrodutos corretos e os demais são abandonados na estrutura. Essa estratégia adotada pela empresa flexibiliza os leiautes dos apartamentos, possibilita maior tempo para a escolha da alternativa e agrega valor ao produto, sem comprometer os prazos da obra, por um custo relativamente baixo.

A aplicação desse padrão seria normal em um novo lançamento. Entretanto, no caso específico do empreendimento Piazza San Pietro, todos os eletrodutos já haviam sido embutidos nas lajes, mas precisaram ser revisados um a um. A equipe de campo examinou todos os encaminhamentos dos eletrodutos através das passagens de cabos guias e verificou que havia obstruções em grande parte deles. Novos eletrodutos precisariam ser lançados em substituição aos obstruídos. Além disso, a modernização do projeto criou a demanda por acréscimo de pontos de força, telefone, cabeamento para TV etc. que necessitariam de novos eletrodutos (Figura 53).

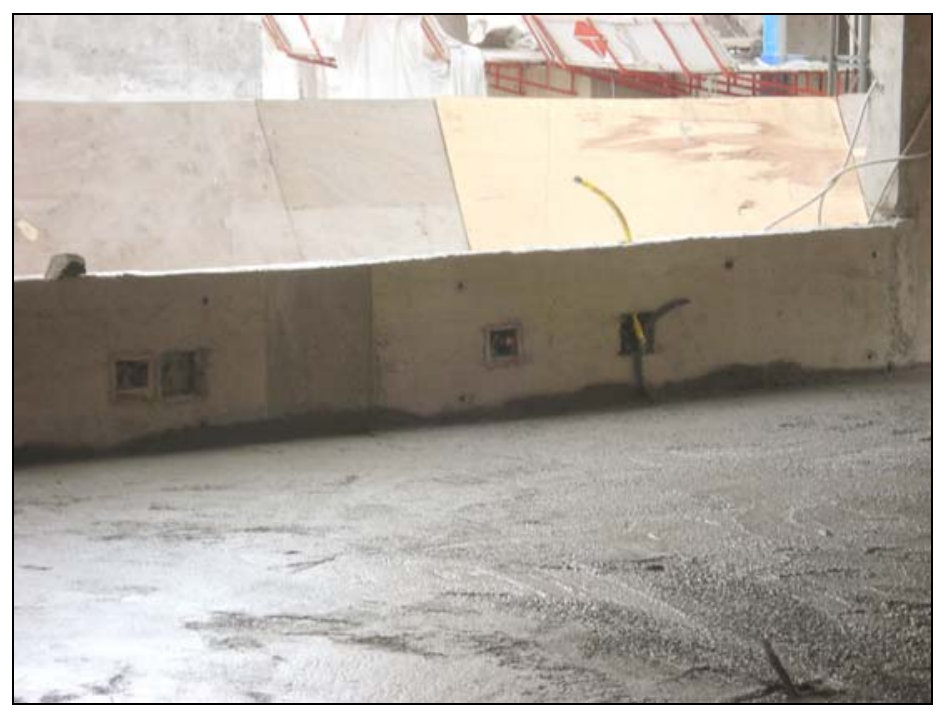

Figura 53 - Novos eletrodutos foram lançados no piso executado para o reforço estrutural das lajes (arquivo do autor)

A empresa contratada para executar os projetos para produção de alvenaria estudou a alternativa da criação de forros nos ambientes, para a passagem dos eletrodutos. Entretanto, as incompatibilidades com a estrutura existente, tais como vigas e altura 
mínima de pé-direito, elevariam sobremaneira o custo da execução, pois os elementos estruturais precisariam ser perfurados e, eventualmente, reforçados.

Nesse momento, mais uma vez o papel da coordenação de projetos, atuando em conjunto com a área técnica da empresa, foi fundamental para a integração da multidisciplinaridade de equipes e para a orientação da seleção alternativa que melhor atenderia a todas as áreas.

Optou-se pelo embutimento dos eletrodutos em caixinhas, no contrapiso e nas vigas invertidas que seriam executados, o que liberou frente para o detalhamento do projeto de elétrica e, posteriormente, para execução dos serviços na obra.

A entrada de energia do edifício ainda não havia sido executada quando da retomada das obras e, portanto, a revisão dos projetos de elétrica contemplaria a nova demanda de carga do edifício.

\section{* Elevadores}

A consultoria em elevadores foi prestada pela empresa parceira da Tecnisa, que realizou levantamentos de campo detalhados. Os levantamentos acusaram desvios de13 a $14 \mathrm{~cm}$ na estrutura da caixa dos elevadores. O enchimento necessário para regularizar o prumo da estrutura e atenuar esta excentricidade provocou outra mudança no projeto, pois foi preciso alterar o posicionamento das portas principais de determinados apartamentos.

\section{* Personalização dos apartamentos}

Mesmo sendo um projeto atípico, a Tecnisa manteve o padrão de oferecer opções de modificações nos projetos dos apartamentos. Para isso criou uma área exclusiva chamada "Departamento Personal" que cuida do atendimento aos clientes, auxilia a escolha de acabamentos, de alternativas de projetos e faz a interface com os projetistas para a readequação dos projetos. Apenas no condomínio Piazza San Pietro a área já contava com 181 solicitações registradas para alterações, de toda natureza, nos apartamentos. Exige-se a execução das modificações com os mesmos projetistas do projeto da edificação, de forma a preservar a garantia do conjunto. 


\subsubsection{Lições aprendidas e comentários finais}

As condições contratuais firmadas pela Tecnisa com os proprietários para reabilitação do condomínio Piazza San Pietro previam flexibilidade no cumprimento dos prazos de execução da obra, devido a sua complexidade. Essa condição, de certa forma, favoreceu a tomada de decisão no canteiro de obras a cada desafio e deu condição mais apropriada, às equipes de projeto, para o desenvolvimento das soluções.

O modelo de coordenação interna, ou seja, a coordenação de projetos exercida por profissional da empresa executora das obras, apresentou-se como uma alternativa relevante no caso estudado. A interface entre equipes de projeto e obra foi, aparentemente, bem resolvida. Na etapa final, a equipe de obras era formada por dois engenheiros e oito estagiários que demandavam a coordenação de projetos.

As discussões técnicas estavam sempre alinhadas aos interesses da empresa e, devido ao fato da coordenação de projetos conhecê-los integralmente, as decisões fluíram naturalmente, sem a necessidade de interlocutores, como mostra a figura 54 :

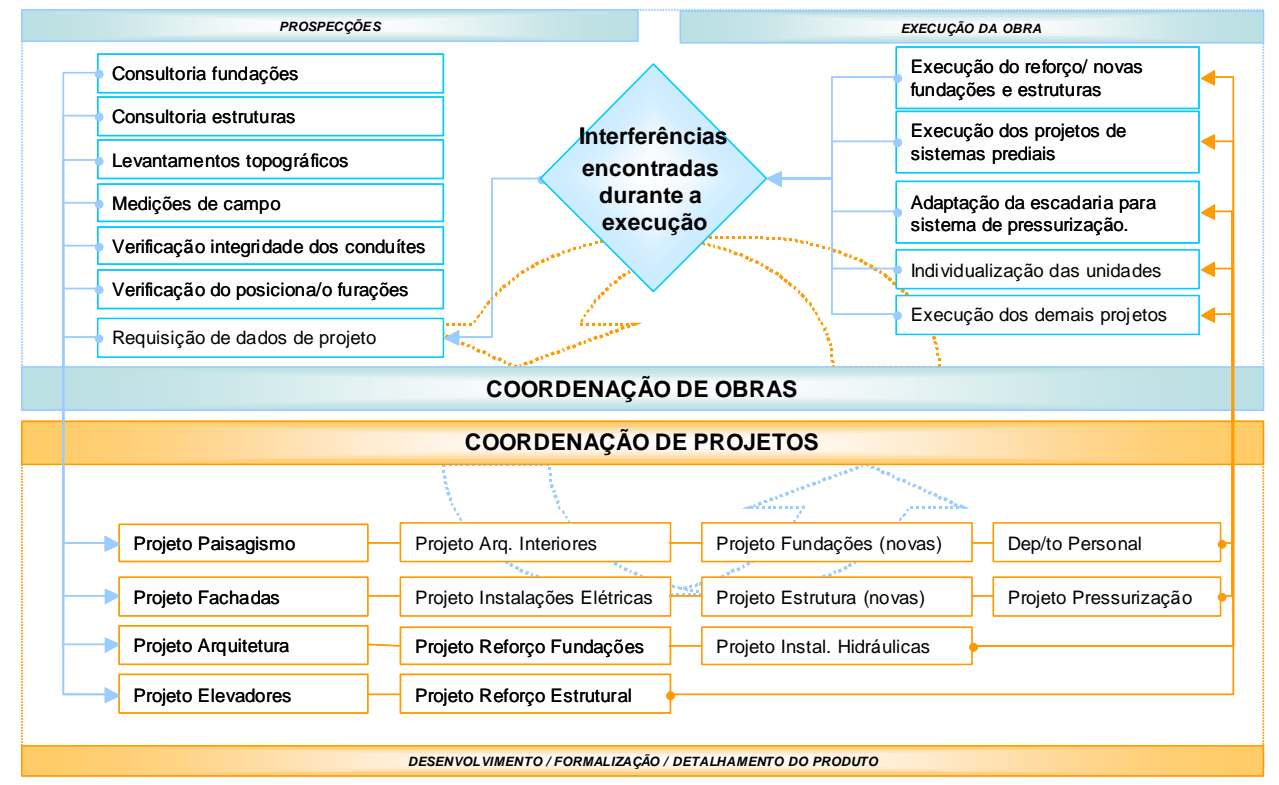

Figura 54 - Integração Projeto x Obra: relacionamento próximo entre as áreas (dados coletados junto à Tecnisa) 
Além disso, a coordenação de projetos que tem sua participação no empreendimento desde o início, na tomada de decisão da empresa pelo negócio, tem condições de propor soluções mais eficientes de projeto, pois se utiliza de uma visão sistêmica do negócio. A coordenação de projetos atuou até o final das obras, com dedicação mínima de três horas por dia para o empreendimento.

Para a Tecnisa, a coordenação de projetos de reabilitação exige a quebra de todos os paradigmas relacionados às atividades de coordenação. Não é possível a utilização dos mesmos procedimentos, cronogramas, fluxos de contratação, modalidades de contratação, produtividades esperadas etc. Os processos precisam ser redesenhados para o novo cenário. Segundo a arqta. Patrícia Valadares, é a "criação de ideais novos que transgridem a nossa cultura".

Ao final do empreendimento, a coordenadora de projetos, arqta Regina Pellizzon, avaliou que deveria ter sido investido mais tempo na elaboração dos projetos, antes do início das obras. Segundo Regina, os projetos de reabilitação não podem ser conduzidos da mesma maneira que os projetos convencionais e o seu prazo para desenvolvimento deve ser maior do que os 150 dias utilizados em empreendimentos novos.

Diferentemente dos demais empreendimentos da empresa, a equipe de obras iniciou os serviços juntamente com a equipe de projetos. Essa mudança no ritmo das atividades exigiu que o perfil dos profissionais envolvidos fosse diferenciado. A seleção das equipes de projeto e obra foi uma das medidas acertadas, na opinião da empresa. Segundo depoimentos coletados pela Tecnisa junto a profissionais das empresas de projeto, o produto final foi comemorado e considerado como uma "realização profissional", em virtude dos desafios apresentados ao longo do empreendimento.

A única exceção apresentada pela Tecnisa, no que diz respeito aos modelos de contratação de subfornecedores, foi a contratação da empresa projetista dos sistemas prediais. Indicada pela empresa instaladora, a Tecnisa entendeu que haveria maior sinergia e, portanto, abriu mão de indicar uma empresa parceira. No decorrer dos trabalhos, a projetista não atendeu às expectativas da Tecnisa e 
iniciou-se uma conturbada relação. A equipe de coordenação de projetos precisou assumir atividades de desenvolvimento de projeto, a fim de suprir as deficiências da empresa contratada. Como lição aprendida, a empresa instaladora deve ser préqualificada e, preferencialmente, parceira da construtora e/ou da incorporadora.

O engenheiro destacado para conduzir as atividades é o profissional que está há mais tempo na empresa e possui grande experiência de obras e conhecimento da cultura da Tecnisa. Na opinião do diretor técnico da empresa, essa foi uma decisão acertada, pois a estabilidade proporcionada pela equipe técnica ao canteiro de obras faz com que a produção atenda aos resultados esperados. Uniu-se, a esse engenheiro, outro profissional para auxiliar na condução do empreendimento.

O impacto social produzido por um empreendimento de reabilitação foi notado pela Tecnisa. Segundo a empresa, além do impacto produzido internamente ao empreendimento com o restabelecimento da possibilidade de os ex-mutuários da Encol usufruírem um bem degradado há tantos anos, a resposta positiva causada no entorno do empreendimento já é perceptível.

Dentre outras lições aprendidas, pode-se perceber que a etapa de prospecções iniciais foi decisiva no empreendimento. A identificação tardia da inadequação do projeto estrutural gerou impactos no desenvolvimento dos projetos, no planejamento, na execução etc. Esse foi um dos principais entraves identificados que influenciaram diretamente no prazo de entrega das obras.

Outro fator que dificultou o prazo de entrega das obras foi a excessiva liberdade concedida aos proprietários para alterar o projeto original. Segundo a arqta Regina Pellizzon, isso contribuiu para aumentar a complexidade da execução, que por si só já não permitia uma padronização que contribuísse para uma melhor produtividade dos serviços.

Os chamados pontos de descontrole, denominados "elementos-surpresa", presentes em grande parte dos empreendimentos de reabilitação, estiveram presentes também no Piazza San Pietro. Os projetos das escadas não foram localizados. As alturas mínimas na escadaria não foram atendidas. 
Com a preocupação de fornecer prontamente as informações relacionadas à segurança e estabilidade das estruturas, estão disponíveis, no canteiro de obras, os laudos e levantamentos técnicos realizados pelos consultores e projetistas de fundação e estruturas, assim como os relatórios de ensaio de integridade e resistência.

$\mathrm{Na}$ opinião dos profissionais entrevistados, os processos desta reabilitação serviram como aprendizado de grande valia para os futuros empreendimentos da empresa. A Tecnisa se auto-avalia mais preparada para um novo desafio semelhante e acredita ter desenvolvido know-how para executar outros projetos dessa natureza. 


\subsection{ESTUDO DE CASO 3: RÉSIDENCE PARK HERMÈS (LYON, PARIS)}

\subsubsection{Histórico do empreendimento}

O empreendimento, objeto deste estudo de caso, situa-se na cidade de Lyon, França. Localizada a 460 km de Paris e capital da região Rhône Alpes, Lyon é a segunda maior cidade da França, com aproximadamente 460 mil habitantes.

Com 102 mil estudantes ${ }^{28}$ (aproximadamente um quarto da população), Lyon conta com quatro universidades, além de inúmeras faculdades em diversas áreas (saúde, tecnologia da informação, direito etc.), sendo que três faculdades de engenharia estão localizadas próximas ao empreendimento.

Isso torna Lyon a segunda maior cidade universitária da França, e essa população estudantil impulsiona o mercado imobiliário residencial local. Com o objetivo de atender a essa demanda, foi lançado o empreendimento residencial Park Hermès (Figura 55).
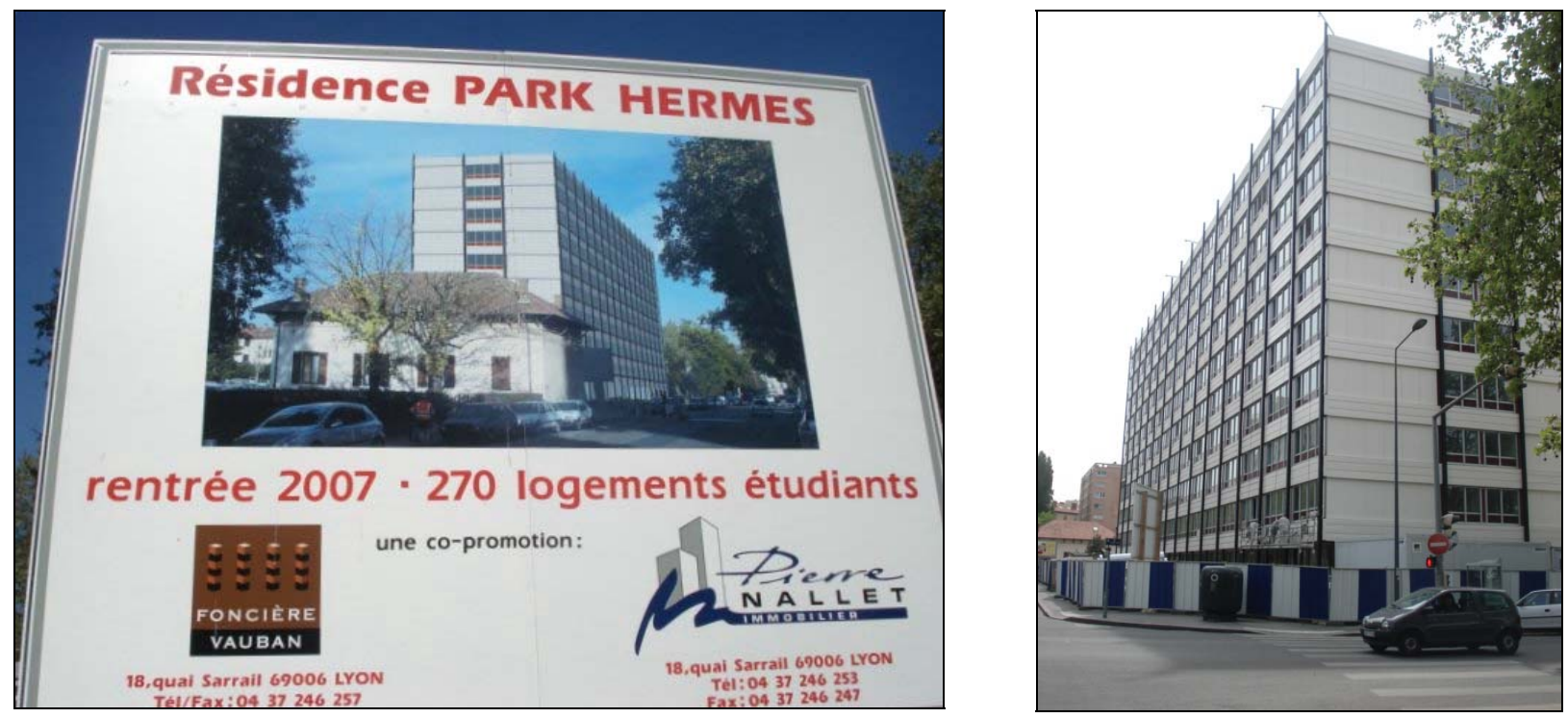

Figura 55 - Placa do empreendimento (esq.) e vista do edifício (dir.) -(arquivo do autor)

\footnotetext{
${ }^{28}$ Disponível em: http://www.lyon.fr/vdl/sections/en/enseignement. Acesso em: 15.07.2007.
} 
O empreendimento, localizado a 15 minutos do centro da cidade de Lyon e a poucos metros da estação Flachet de metrô, foi projetado pelos arquitetos Marcel Lods, Paul Depondt e Henri Beauclair e construído, em 1972, para uso comercial.

Recentemente, o Park Hèrmes foi submetido ao processo de reabilitação com mudança de uso e convertido para abrigar residências projetadas para o público estudantil.

A edificação, construída em estrutura metálica, foi projetada originalmente para abrigar escritórios comerciais. No início da década de 1990, após vinte anos locado para uma mesma empresa, o elevado custo de operação e manutenção da edificação contribuiu para que esta empresa desocupasse o imóvel. Os sistemas prediais que se encontravam ineficientes e desatualizados contribuíram para a desvalorização comercial do edifício, que ficou vago desde então.

A localização do empreendimento e a infra-estrutura existente na região do edifício (Figura 56) despertaram o interesse dos incorporadores do Park Hermès e, em meados de 2004, decidiram adquirir o imóvel.

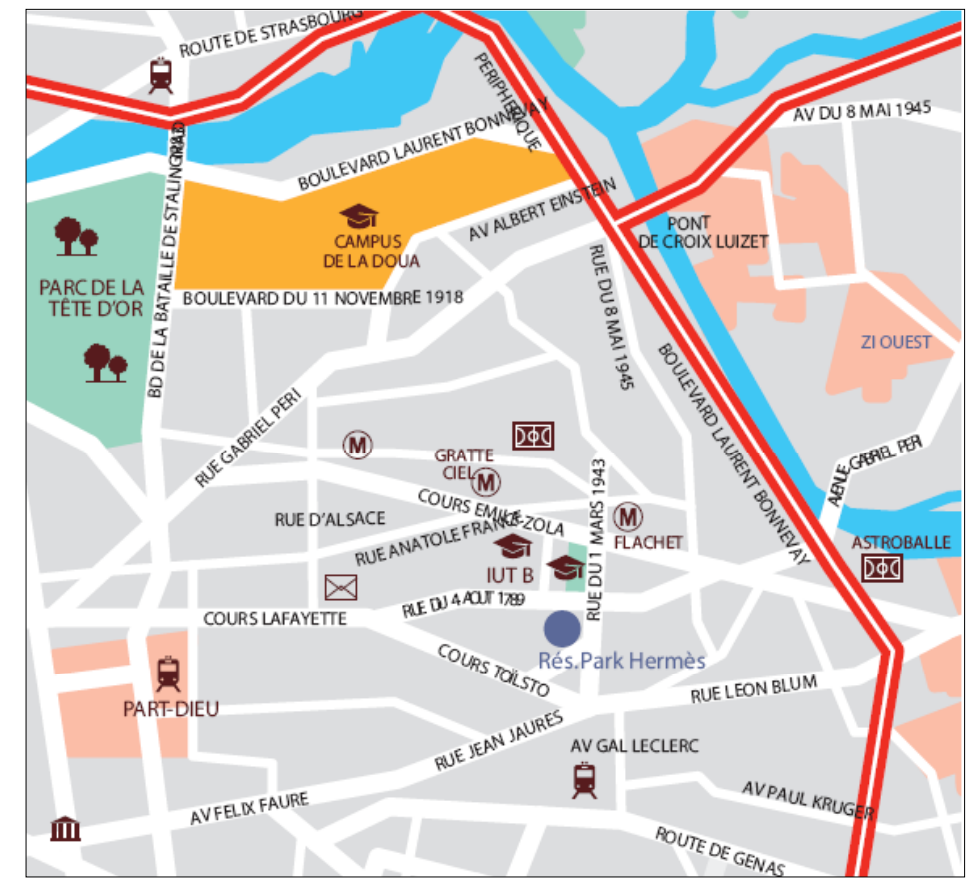

\footnotetext{
${ }^{29}$ Dados retirados do material publicitários do empreendimento, disponível em: http://www.abeliante.com/media/id lyonvilleurbanne hermes.pdf. Acesso em 15.11.2007.
} 
Inicialmente, a estratégia dos incorporadores previa a demolição completa da edificação e a construção de um galpão industrial em seu lugar. Mas o poder público local os impediu de seguir adiante e os obrigou a mudar de estratégia. O poder público municipal havia indicado o Park Hermès para a lista dos patrimônios históricos do século vinte, conforme o documento "Patrimonie du $X X^{\text {éme }}$ siécle en Rhônes-Alpes, 2000" e, portanto, a sua demolição ou descaracterização arquitetônica estaria proibida ${ }^{30}$.

Cada região, na França, elaborou seu próprio documento em que foram relacionados os empreendimentos considerados patrimônio histórico do século XX e que passariam a ser protegidos por lei. A partir daí, foram estudadas as alternativas de reabilitação da edificação e optou-se pela mudança de uso voltada para o público estudantil local.

\subsubsection{Estudo de viabilidade}

A reabilitação do Park Hermès foi um desafio aos projetistas, uma vez que havia sido construído há mais de três décadas, em estrutura metálica e com a finalidade de uso comercial. Agora, o projeto de reabilitação deveria atualizar a edificação quanto às exigências legais de desempenho termo-acústico, segurança estrutural e ao fogo etc., para o uso residencial (França, Code de la construction - articles R11). E, ainda, essa adequação não poderia afetar as características arquitetônicas da edificação, uma vez que ela foi considerada patrimônio histórico.

Para isso, foi realizado um diagnóstico completo da edificação por escritórios de engenharia especializados (bureau d'etudes). Os principais aspectos desse diagnóstico foram as questões de segurança estrutural e ao fogo do edifício como um todo, além das questões de desempenho térmico e acústico com relação às fachadas e suas interfaces.

\footnotetext{
${ }^{30}$ Disponível em: http://www.culture.fr/documentation/milxx/pres.htm Acesso em 15.jul.2007.
} 
Os resultados dos diagnósticos eram trazidos aos projetistas de arquitetura que, juntamente com os escritórios de engenharia especializados, estabeleciam as diretrizes de projeto economicamente viáveis. A coordenação dos trabalhos foi conduzida pelo projetista de arquitetura e pelo engenheiro responsável da incorporadora.

O estudo de viabilidade, que durou aproximadamente seis meses, pode ser dividido em cinco grupos principais, conforme ilustrado na figura 57 :

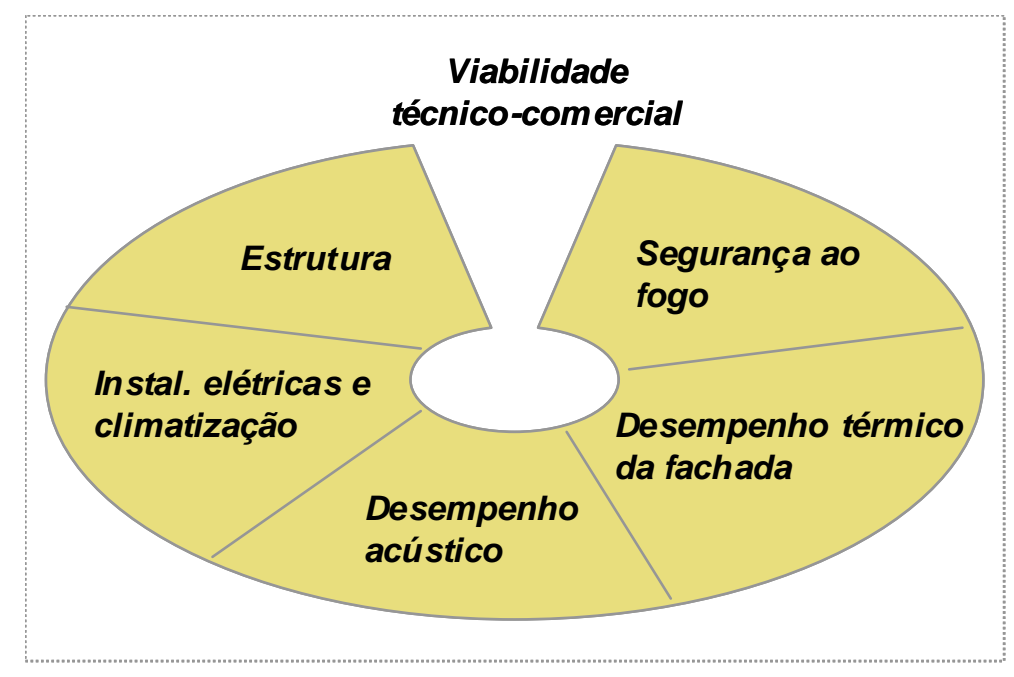

Figura 57 - Principais aspectos do estudo de viabilidade (dados coletados durante as entrevistas)

\section{Estrutura}

A questão central do estudo de viabilidade da reabilitação das estruturas era se o estado dos perfis metálicos seria aceitável e se a estrutura, como um todo, suportaria as novas cargas que Ihe seriam aplicadas. As cargas dos elementos que seriam instalados para melhorar o desempenho ao fogo, térmico e acústico precisariam ser computadas. Além disso, havia a preocupação com a estabilidade horizontal da estrutura.

O levantamento diagnóstico apontou que o estado de conservação dos perfis era bom e poderiam ser aproveitados. Entretanto, o edifício não apresentava estabilidade horizontal suficiente para atender às exigências legais vigentes. Além disso, a necessidade de reforços na estrutura e fundação, devido à sobrecarga na estrutura, precisaria ser analisada. 


\section{* Segurança ao fogo}

Com relação à segurança ao fogo, os pilares metálicos da periferia do edifício, que são aparentes, não possuíam nenhum tipo de proteção. Além disso, as unidades habitacionais e as áreas de circulação deveriam atender aos critérios mínimos de TRRF (Tempo Requerido de Resistência ao Fogo).

O diagnóstico realizado na edificação apontou que o sistema de proteção contra o fogo estava vulnerável. Dos elementos de fachada à estrutura de sustentação do edifício, todo o sistema estaria comprometido e precisaria sofrer uma intervenção complexa.

\section{* Fachada: desempenho térmico}

O sistema utilizado nas fachadas é um elemento importante para o desempenho térmico de toda a edificação. Entretanto, por se tratar de um patrimônio histórico, suas características precisariam ser mantidas. Ou seja, poderia ser substituído por outro sistema, com elementos novos, desde que preservasse as características estéticas originais da década de 1970.

O resultado do diagnóstico apontou que o sistema de fachadas foi reprovado nos requisitos: desempenhos térmico, acústico, de estanqueidade ao ar e à água.

\section{* Acústica}

A questão do desempenho acústico da edificação permearia as definições sobre o tipo da composição dos elementos de vedação, escolha de materiais para piso, fachada etc.

\section{Adequação das instalações elétricas e de climatização}

A questão levantada em relação às instalações elétricas e de climatização foi que elas deveriam ser substituídas, integralmente, por sistemas mais eficientes e que atendessem à demanda do novo uso da edificação. 
Entretanto, as limitações físicas impostas pela estrutura - como altura do pé direito dos andares - e o cuidado para que as tubulações (Figura 58) não servissem de passagem para ruído, vibração e, até mesmo, de incêndio entre as unidades habitacionais, foram desafios para as equipes de projeto.
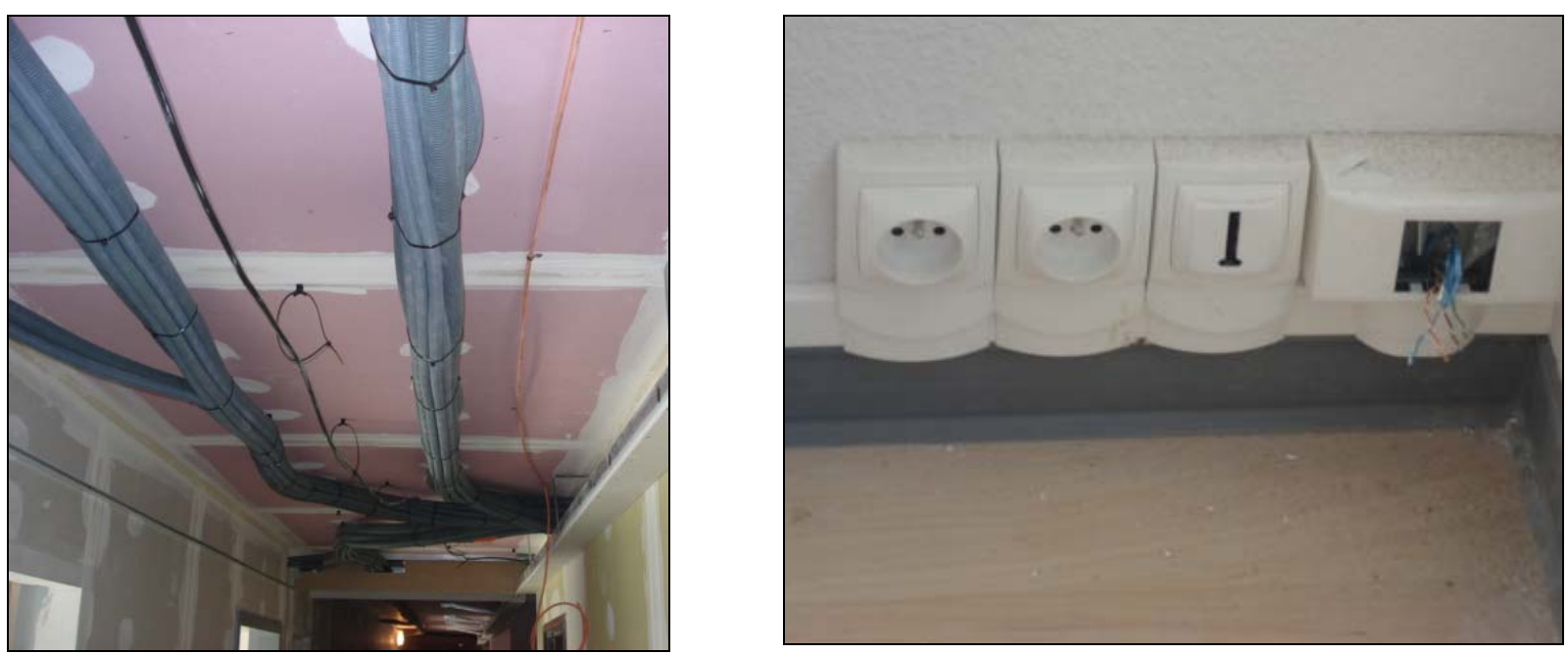

Figura 58 - Instalações originais substituídas (esq.). Instalações elétricas aparentes para evitar pontes de transferência entre os apartamentos (dir.) - arquivo do autor

A coordenação de projetos identificava as interferências entre as soluções dos diversos aspectos do estudo de viabilidade, e conduzia para que fossem solucionadas. Da mesma forma, as interfaces entre as áreas foram sendo tratadas e as alternativas de projeto foram sendo apresentadas.

Impulsionado pela alta demanda do mercado por imóveis destinados à moradia estudantil na região, o estudo de viabilidade sinalizou positivamente e as obras de reabilitação foram iniciadas em 2005.

\subsubsection{Caracterização do empreendimento}

Assim como ocorre no Brasil, as edificações construídas em estrutura metálica, na França, requerem cuidados especiais no que diz respeito ao atendimento dos requisitos de segurança contra incêndio. 
A complexidade técnica e o custo do atendimento rigoroso às normas vigentes de segurança ao fogo podem, eventualmente, inviabilizar um empreendimento de reabilitação de edifícios.

Por essa razão, certos países europeus têm solucionado essa questão de maneiras alternativas. Denominada "engenharia de incêndio", os estudos consistem em garantir a estabilidade global do edifício numa situação de sinistro, com a aplicação de medidas compensatórias como, por exemplo, o aumento do número de chuveiros contra incêndio na edificação (CROITOR; OLIVEIRA; MELHADO, 2007).

Entretanto, no Park Hèrmes, os estudos para adequação da estrutura metálica para a resistência ao fogo acusaram a necessidade de criação de novos pilares metálicos na estrutura (Figura 59). A estrutura do edifício é composta por perfis metálicos na periferia, desprotegidos da ação do fogo. No caso de incêndio, a estrutura não estaria pronta para resistir e, portanto, a sua adequação seria complexa.

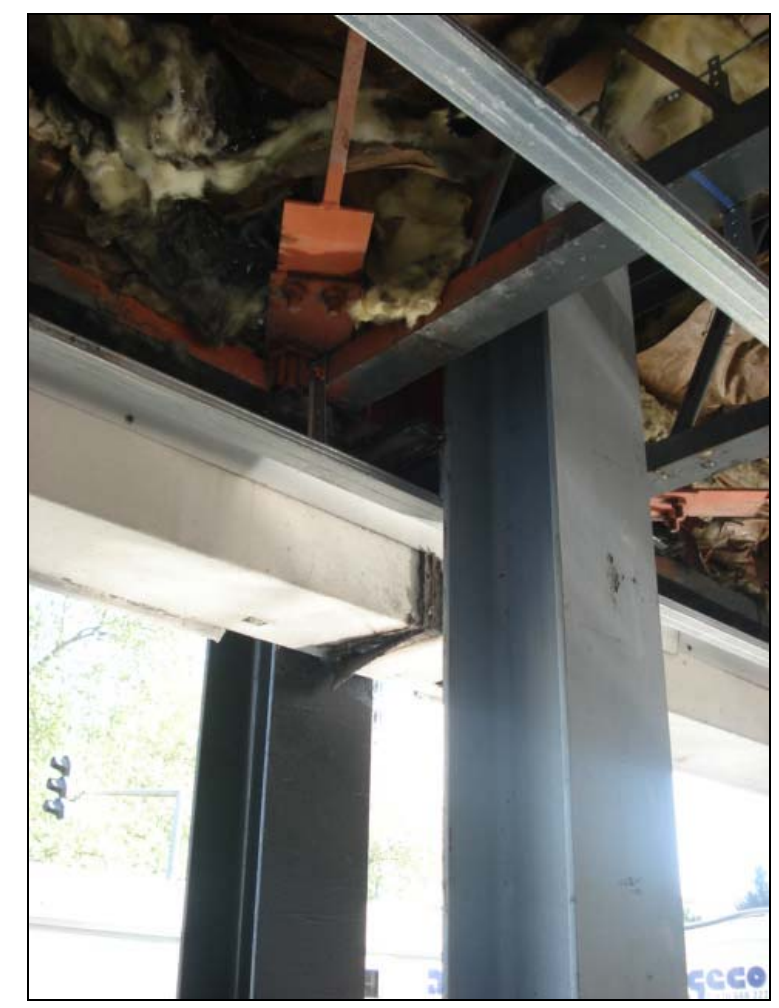

Figura 59 - Novo pilar metálico instalado junto à estrutura existente (arquivo do autor) 
Os fechamentos internos originais foram projetados para a utilização em salas comerciais. Os materiais aplicados nas divisórias e nos forros eram constituídos de madeira e cimento-amianto e estruturados com perfis de alumínio.

A solução adotada no Park Hèrmes previu a instalação de forros e divisórias, ambos em gesso acartonado. As aplicações foram feitas de acordo com a exposição de cada elemento de vedação: áreas úmidas (chapas cor verde), áreas secas (amarelo tradicional) e com resistência contra fogo (chapas cor rosa).

O isolamento termo-acústico das divisórias internas, outra questão importante relacionada ao desempenho, foi projetado a partir de chapas duplas de gesso acartonado com o miolo das paredes e das lajes preenchido com camadas de lã de rocha.

Além disso, as unidades habitacionais foram projetadas de maneira que não tivessem qualquer "ponte de transferência" (acústica, térmica, de incêndio etc.) entre si. Essas considerações, eventualmente, ocasionaram um maior sobrepeso para a estrutura e, por conseqüência, aumento de custo do empreendimento.

\subsubsection{Organização do empreendimento}

As principais informações relativas à comercialização do residencial Park Hèrmes podem ser encontradas no material de publicidade do empreendimento ${ }^{31}$. Nesse documento, além das informações triviais dos materiais de publicidade, tais como: características do imóvel, área útil construída, dependências das áreas comuns etc., encontram-se também dados dos responsáveis pelo empreendimento: nome dos incorporadores, dados financeiros do gestor, dados dos responsáveis pela área contábil, jurídica e fiscal, breve currículo das empresas envolvidas etc.

\footnotetext{
${ }^{31}$ Dados retirados do material publicitários do empreendimento, disponível em: http://www.abeliante.com/media/id lyonvilleurbanne hermes.pdf. Acesso em 15.11.2007.
} 
Esse panorama geral do empreendimento, formatado antes do seu lançamento, permite que o consumidor conheça os agentes nele envolvidos.

No caso do Park Hèrmes, os principais agentes envolvidos são (Figura 60):

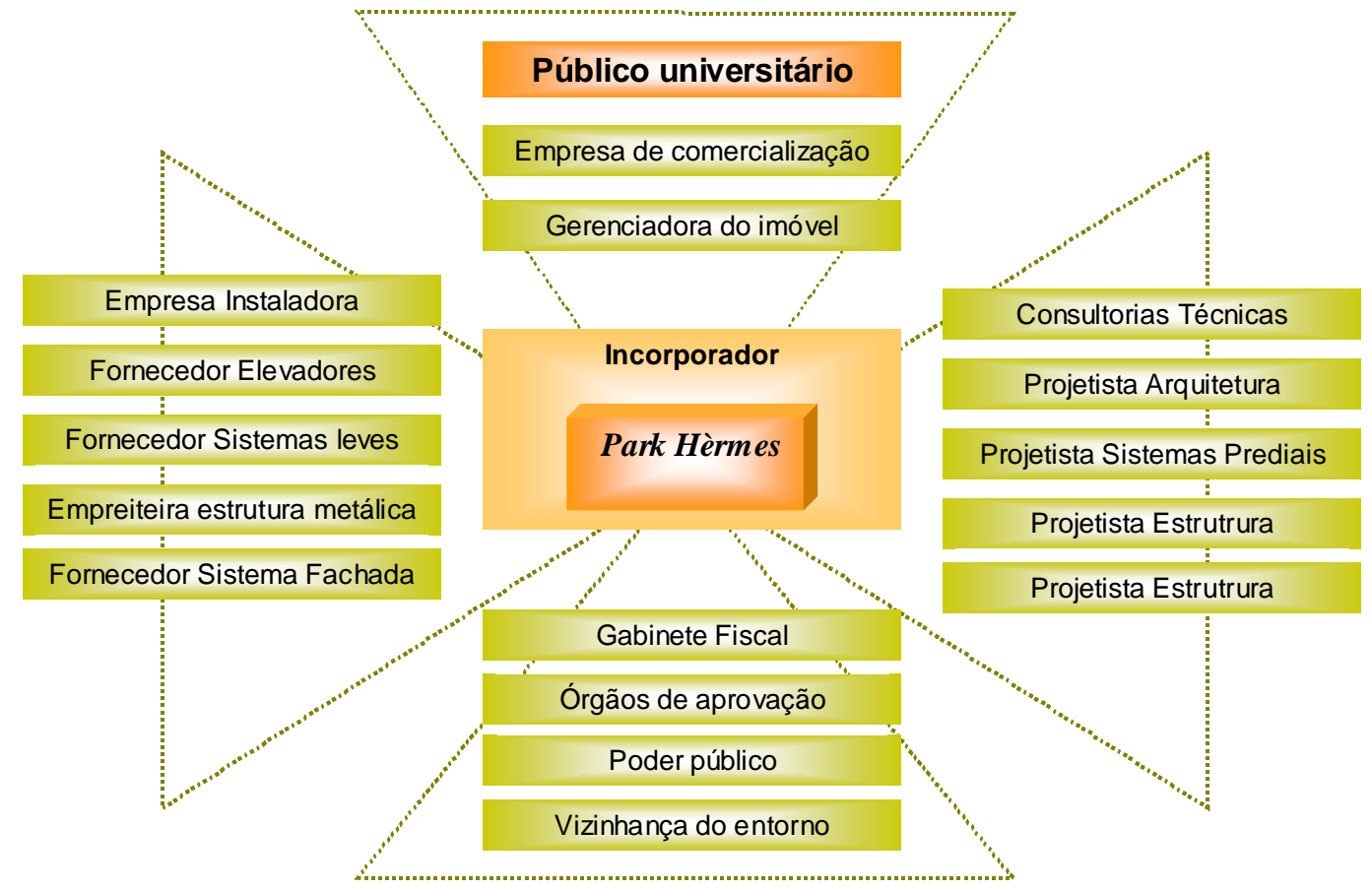

Figura 60 - Principais agentes envolvidos no empreendimento (fonte: dados coletados durante as entrevistas)

O papel dos incorporadores foi além de simples financiadores. Sua atuação no canteiro de obras foi efetiva, cumprindo, eventualmente, o papel de coordenador de projetos em conjunto com o projetista de arquitetura e de coordenador das obras com os empreiteiros. O agente responsável pelo gerenciamento do empreendimento é aquele que fará a gestão do imóvel na operação.

\subsubsection{Estado geral da edificação}

Embora a edificação estivesse abandonada há mais de dez anos, o estudo de viabilidade não acusou a necessidade de recuperação da estrutura existente. Os pilares metálicos que foram incorporados à estrutura, mencionados anteriormente, 
foram especificados para atender à exigência de segurança contra incêndio, uma vez que precisavam ser enclausurados.

Por outro lado, a caixilharia das fachadas encontrava-se totalmente comprometida. Devido ao seu alto grau de deterioração, a decisão de substituí-la seria economicamente mais interessante. O custo de reforma dos caixilhos (Figura 61), segundo informou o incorporador do empreendimento, não seria economicamente viável, uma vez que o custo para torná-los estanques seria muito elevado.

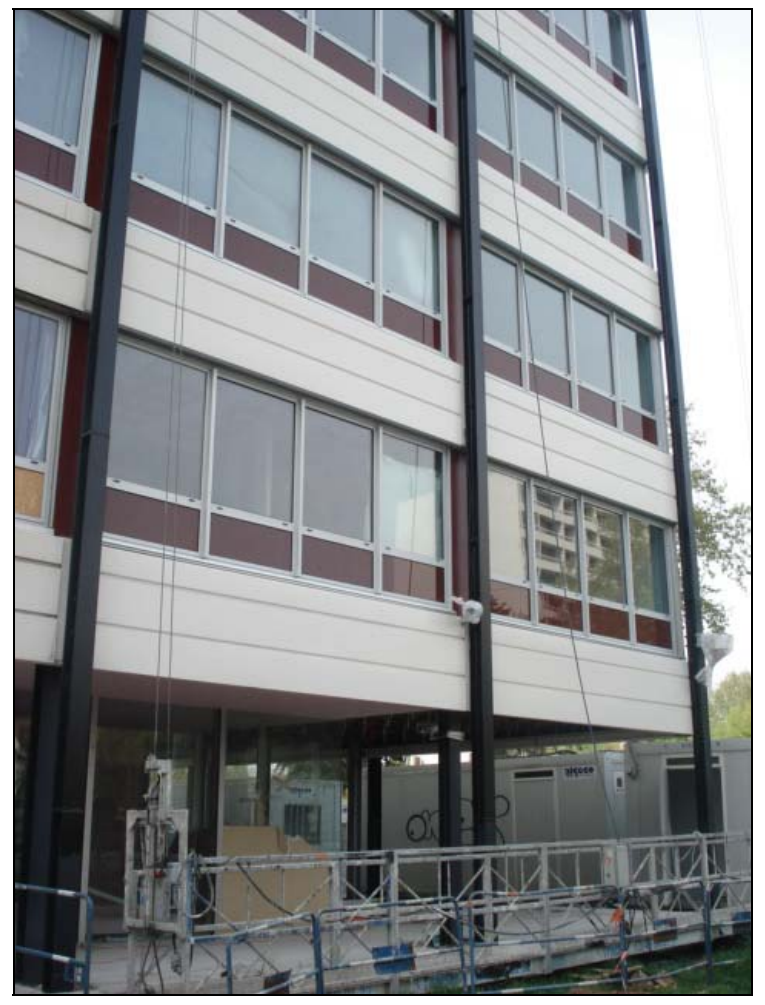

Figura 61 - Caixilhos da fachada: substituição total (arquivo do autor)

Internamente à edificação, as divisórias leves instaladas deveriam ser totalmente removidas e não poderiam ser reaproveitadas. Da mesma forma, foram descartados os sistemas prediais. As cabines dos elevadores, assim como os seus motores, puderam ser recuperados em grande parte. A casa de máquinas, localizada na cobertura do edifício, foi reabilitada. O edifício não conta com sistema de lazer e as áreas comuns, no térreo, são relativamente pequenas, sem nenhum equipamento comunitário instalado. 


\subsubsection{O processo de projeto}

A adoção de sistemas leves em empreendimentos de construção civil de edificações, na França, está consolidada. As soluções adotadas no Park Hèrmes seguiram essa diretriz, o que facilita sobremaneira a execução das obras no aspecto de prazo, organização da produção, planejamento do canteiro, consumo de materiais etc., além de minimizar a sobrecarga aplicada na estrutura e nas fundações.

Atrelado a esses benefícios dos sistemas leves, sempre que possível foram contratados os "sistemas" junto aos subfornecedores. Ou seja, os fornecedores entregam "soluções prontas" e não "partes" que precisam ser unidas por um outro agente interventor. Por exemplo, o fornecimento de divisórias, forro e pisos internos (Figura 62) foram contratados junto a uma empresa responsável pelo dimensionamento, fornecimento e aplicação dos materiais na obra, ficando ela responsável por todo o processo (dimensionamento e controle do recebimento de materiais, execução dos serviços, qualidade, prazo de entrega, garantia etc.).
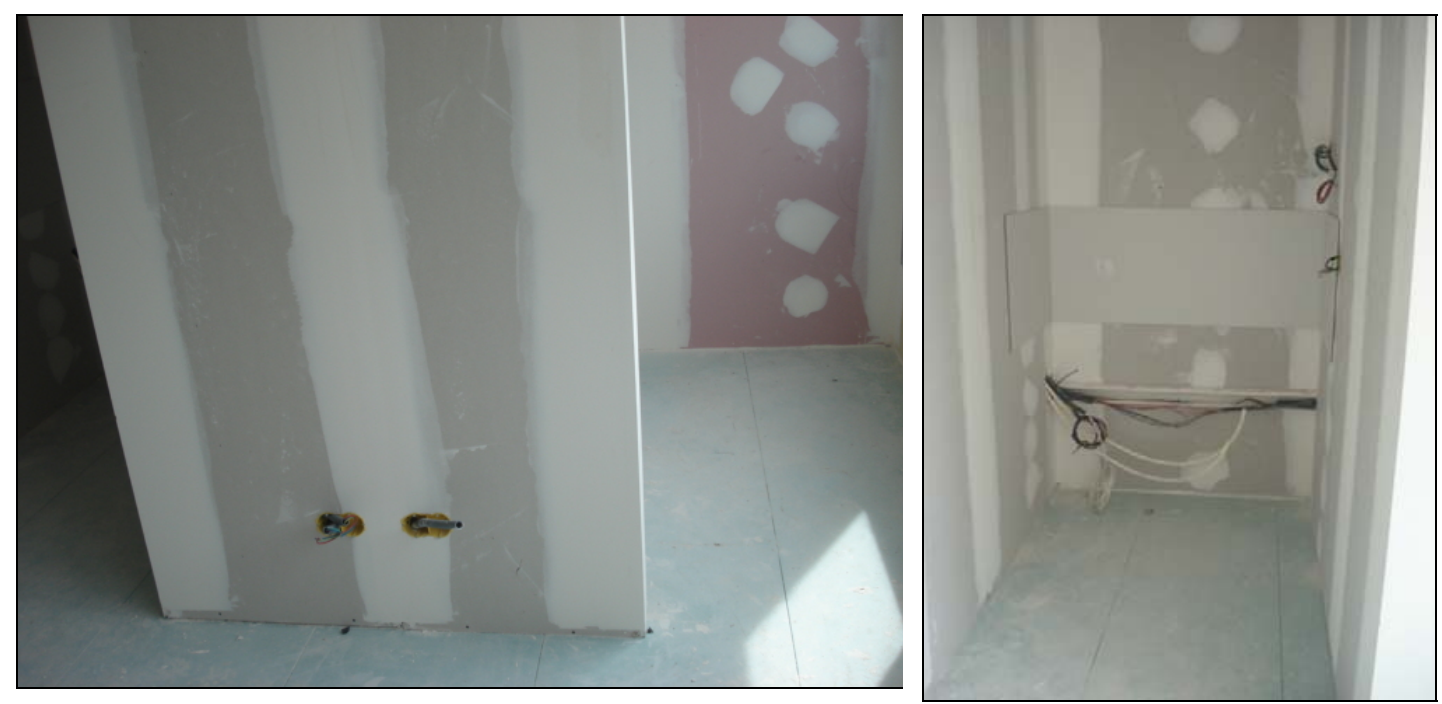

Figura 62 - Sistema de vedação interno em placas de gesso acartonado (esq.), inclusive na área da cozinha do apartamento (dir.) - arquivo do autor 
Isso facilita bastante as atividades de projeto e, conseqüentemente, a execução das obras. Além da facilidade e rapidez com que se executam esses tipos de sistemas leves, a limpeza do canteiro ajuda na organização da produção. Nesse empreendimento, por exemplo, o transporte vertical de materiais foi executado utilizando-se as cabines de elevadores de passageiros existentes, que foram protegidas internamente.

Outro sistema contratado no empreendimento foi o de elevadores (Figura 63). Os projetos foram delegados a uma empresa especializada que recuperou os motores e acessórios existentes e adaptou as cabines de passageiros aos padrões atuais.

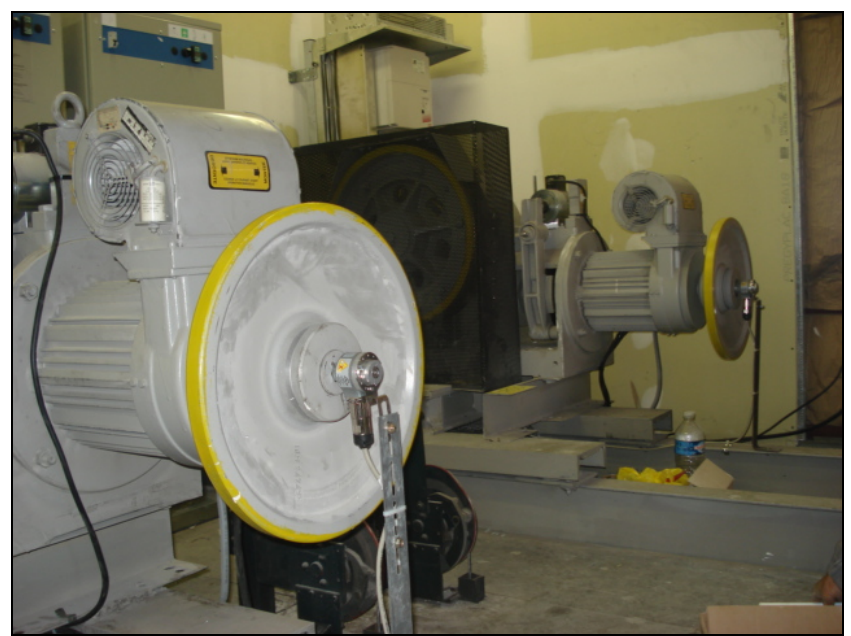

Figura 63 - Casa de máquinas dos elevadores (arquivo do autor)

As lajes dos pavimentos receberam um reforço estrutural com a instalação de vigas metálicas. O objetivo era aumentar a inércia do conjunto e, através do aumento do contraventamento (Figura 64), melhorar a estabilidade horizontal da edificação. Entretanto, os perfis utilizados na construção do edifício já estavam obsoletos e não eram mais fabricados. Os projetistas tiveram que solucionar a incompatibilidade de bitolas dos perfis, somada à pouca altura disponível, sem que comprometesse a altura do pé-direito mínimo exigido pelos códigos de obra municipais. 

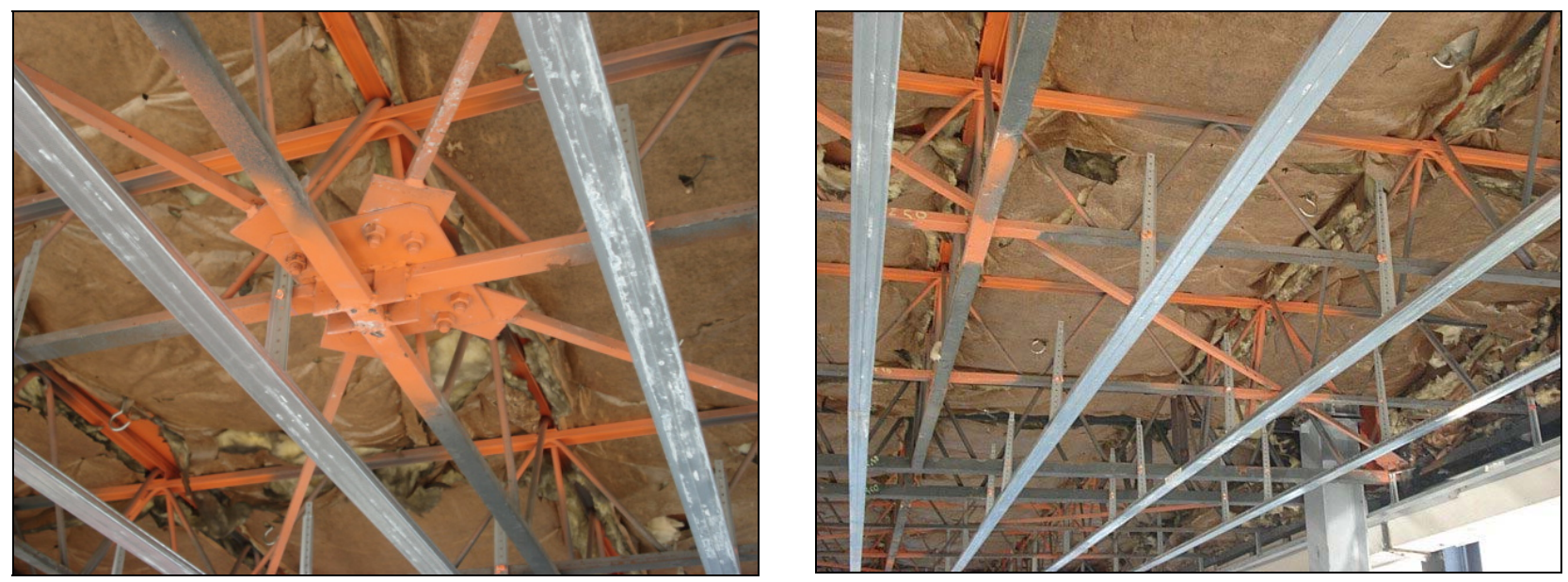

Figura 64 - Contraventamento das lajes para melhoria da estabilidade horizontal (arquivo do autor)

A solução dada para substituição dos elementos de fachada considerava a incorporação de vidros duplos e isolantes nas áreas "não envidraçadas". Esses elementos, que seriam fixados diretamente na própria estrutura do edifício, fazem parte de um estudo que envolveu os fabricantes, instaladores e projetistas desde as etapas de diagnóstico. Embora a solução tecnológica devesse ser contemporânea, a modulação e cor deveriam ser semelhantes às originais.

O modelo de gestão adotado pelo Park Hèrmes não previu, para todas as etapas do empreendimento, a atuação de um coordenador de projetos. Questionado sobre a existência de uma coordenação de projetos, o engenheiro responsável da incorporadora informou que era ele quem, pessoalmente, cumpria esse papel. Entretanto, percebeu-se que nas primeiras etapas do empreendimento houve a participação do projetista de arquitetura na coordenação dos projetos. Segundo o mesmo entrevistado, a execução das obras foi a parte mais simples: "difícil foi dar as soluções de projeto".

\subsubsection{DETALHAMENTO DO PRODUTO}

A reabilitação do Park Hèrmes foi projetada para abrigar 271 habitações, distribuídas em 9 pavimentos, subsolo com 88 vagas para automóveis e vagas para 
estacionamento de 200 bicicletas, no pavimento térreo. Ainda nesse pavimento foi prevista a construção de um escritório com recepção (Figura 65), pequeno refeitório, apartamento para funcionário (vigia), área de depósito e banheiros, além do hall de entrada do edifício.

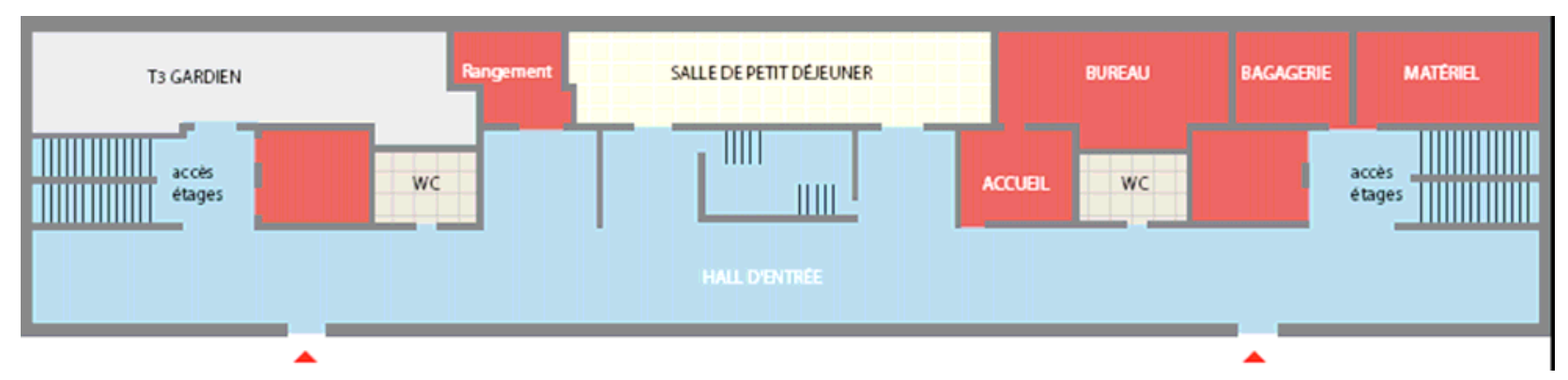

Figura 65 - Planta do pavimento térreo ${ }^{32}$

Os apartamentos possuem um dormitório e áreas úteis de $23 \mathrm{~m}^{2}$ e $41 \mathrm{~m}^{2}$ dependendo da tipologia T1 ou T2 (Figura 66).
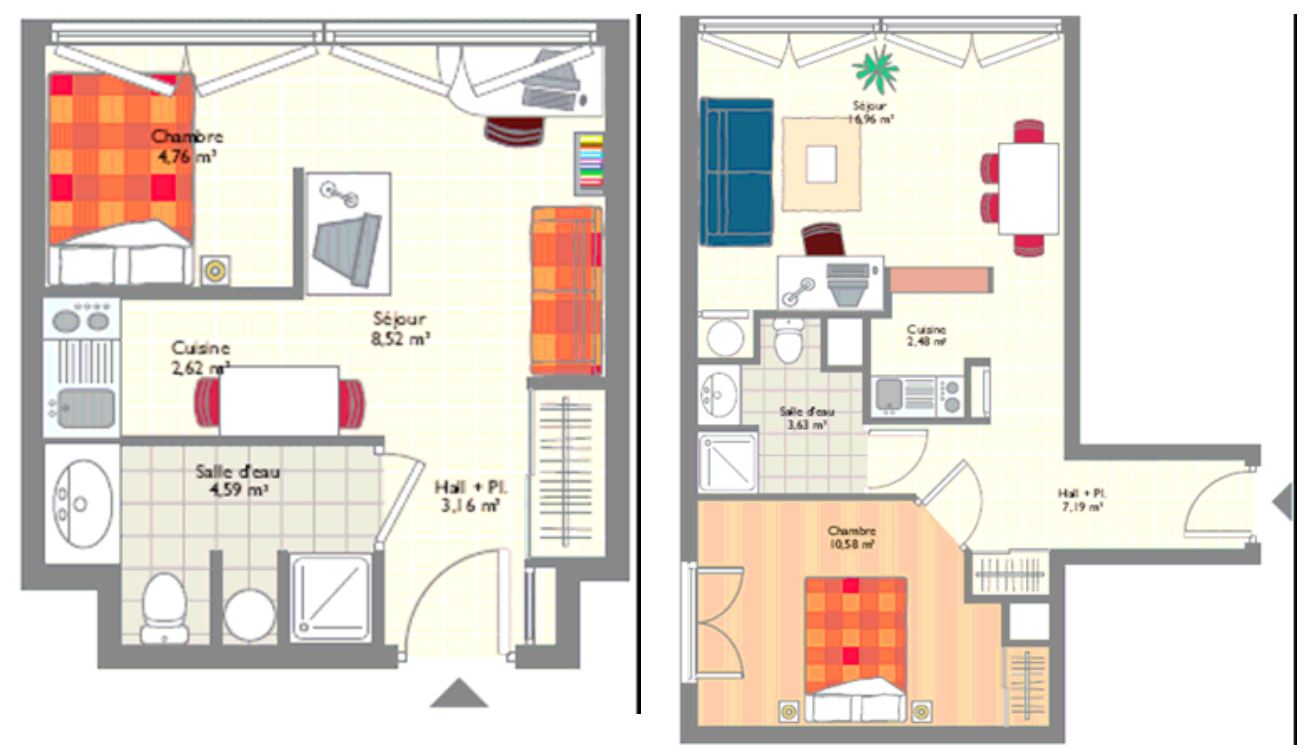

Figura 66 - Tipologia "T1": 234 unidades com 23m² (esq.) e tipologia "T2": 36 unidades com $41 \mathrm{~m}^{2}$ (dir.) ${ }^{33}$

Independentemente da tipologia, serão instalados nos apartamentos o sistema de condicionamento de ar com regulagem eletrônica, o aquecimento de água contará

\footnotetext{
${ }^{32}$ Dados retirados do material publicitários do empreendimento, disponível em: http://www.abeliante.com/media/id lyonvilleurbanne hermes.pdf. Acesso em 15.11.2007. ${ }^{33}$ Idem.
} 
com um boiler elétrico, com capacidade de 100 litros (Figura 67) e suporte com "secador" de toalhas. Os imóveis serão entregues mobiliados com armários embutidos, estantes, mesa para estudos, cadeiras etc.
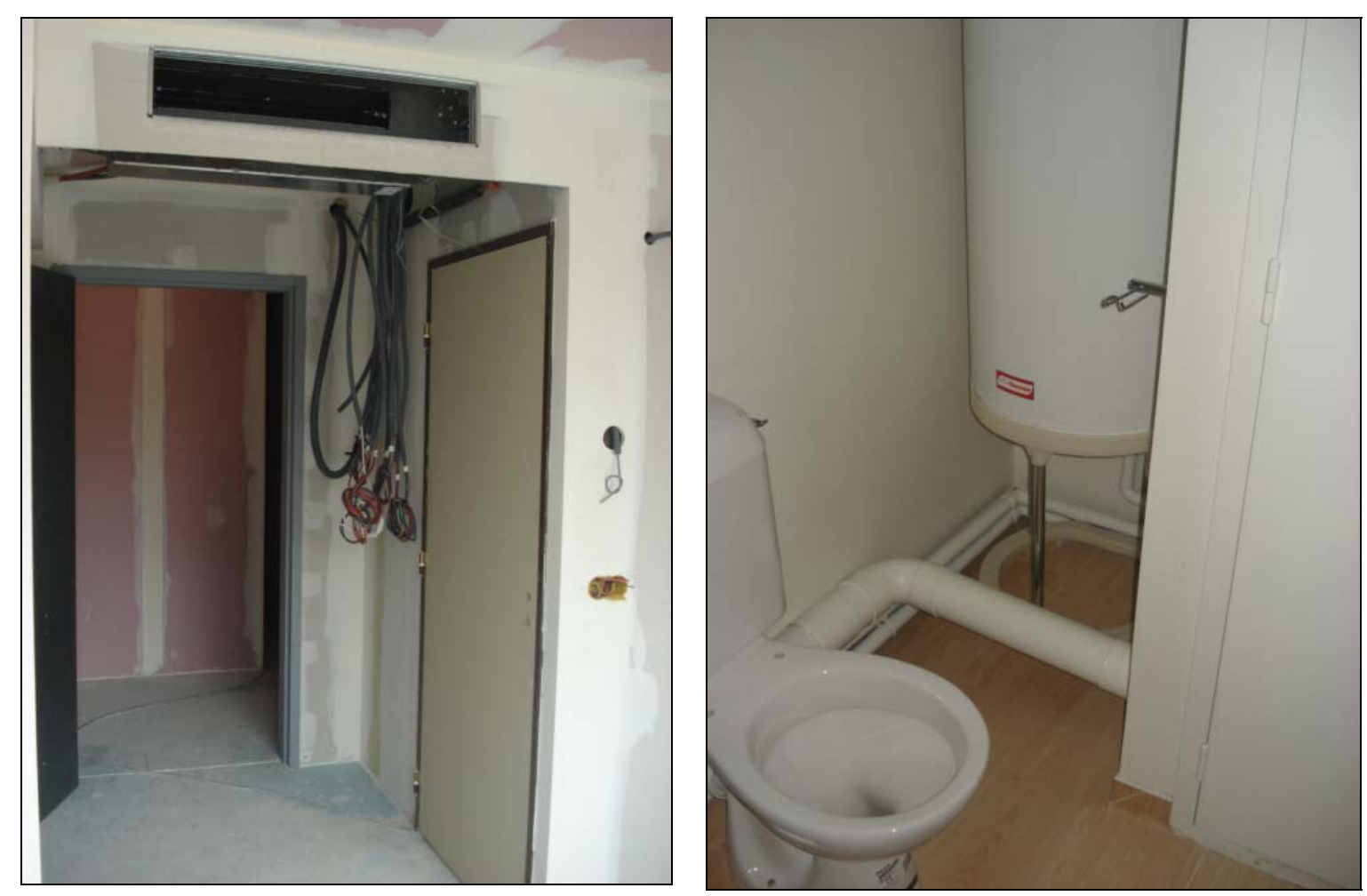

Figura 67 - Sistema de climatização instalado em todos os apartamentos (esq.). Boiler de aquecimento de água e tubulação hidro-sanitária aparente (dir.) - arquivo do autor

O cumprimento das exigências de segurança contra incêndio prevê a instalação de sensores de fumaça nos andares e sistema de exaustão de fumaça nos corredores e nas escadarias. Esse sistema, ao ser acionado pelo detector de fumaça, promove a sucção da fumaça do andar (Figura 68) por um duto que se estende até à cobertura do prédio. Em todos os apartamentos foram instaladas portas de madeira corta-fogo com resistência para 60 minutos. 

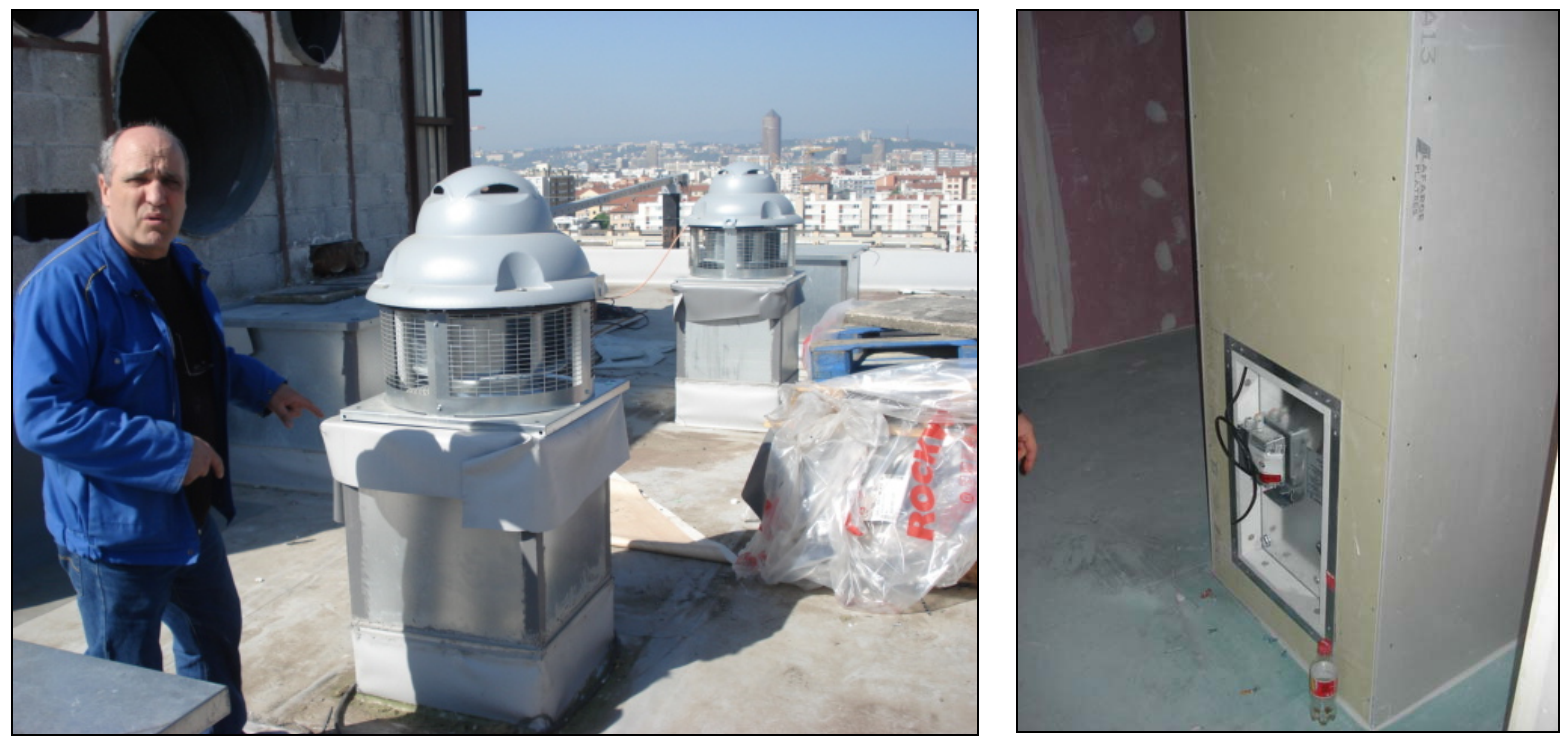

Figura 68 - Sistema de exaustão de fumaça acionado pelos detectores de fumaça. Abertura de captação de fumaça nos pavimentos (dir.) - arquivo do autor

\subsubsection{Lições aprendidas e comentários finais}

O depoimento do engenheiro responsável pela incorporadora: "a execução da obra é simples, difícil é pensar as soluções de projeto", demonstra que a prática de projetar e planejar as soluções para a reabilitação, antes do início das obras e, portanto, fora do canteiro de obras, traz benefícios para a etapa de execução.

Esse processo é iniciado na etapa de diagnóstico para o estudo de viabilidade. O estudo de caso apresentado é um exemplo de cumprimento da etapa mais importante para os empreendimentos de reabilitação. Nessa etapa, os desafios de projeto são mapeados e as alternativas conceituais de projeto passam a ser discutidas e mensuradas. O fruto dessa análise é a viabilidade ou não do empreendimento de reabilitação.

Além disso, o estudo de caso apresentado trouxe outra importante contribuição ao modelo de gestão de empreendimentos de reabilitação: a necessidade do envolvimento da área técnica de projetos, consultoria e execução e os principais fornecedores, desde as etapas preliminares do empreendimento. 


\section{CONSIDERAÇÕES FINAIS}

Entende-se que o objetivo inicial do trabalho foi alcançado. Foram realizadas a análise e a descrição da gestão do processo de projeto em empreendimentos de reabilitação de edifícios. As características particulares desse tipo de empreendimento foram mapeadas e os principais entraves, que ocorrem na interface entre a fase de projeto e execução da obra, foram identificados. Além disso, foram identificadas as principais demandas da gestão de projetos e da execução de obras de reabilitação de edifícios, para as quais foram propostas diretrizes apropriadas.

Conforme apresentado no trabalho, a reabilitação de edifícios não está limitada somente às edificações antigas e degradadas, mas também se aplica, por exemplo, quando há interesse do empreendedor pela substituição de sistemas prediais ineficientes e/ou inadequados, pela mudança de uso do imóvel ou, também, quando as edificações se encontram inacabadas e abandonadas. Ou seja, há um amplo campo de aplicação de empreendimentos dessa natureza, que se traduz em oportunidades de negócio para as empresas e profissionais do setor da construção civil.

Do ponto de vista comercial, a reabilitação de edifícios pode contribuir para recobrar parte da valorização de mercado do imóvel, o que nem mesmo as práticas adequadas de manutenção poderiam proporcionar.

Dentre as diversas etapas de um empreendimento de reabilitação, aquela que se destaca pela importância e por estar diretamente relacionada ao sucesso do empreendimento é a de diagnóstico e estudo de viabilidade. Se em empreendimentos convencionais as etapas preliminares são importantes para o processo de projeto, na reabilitação a etapa de diagnóstico e viabilidade identificará as limitações e oportunidades da estrutura existente e será instrumento fundamental para o desenvolvimento dos projetos. 
$\mathrm{Na}$ etapa preliminar, as condicionantes impostas pelo edifício e seu entorno devem ser amplamente investigadas, pois uma simples informação omitida, nessa etapa, pode provocar graves impactos em todo o andamento do empreendimento, podendo, em última análise, chegar a inviabilizá-lo técnica e comercialmente. Assim, o resultado do empreendimento está diretamente relacionado à quantidade e à qualidade das informações coletadas nas etapas iniciais.

Empreendimentos de reabilitação possuem a característica de impor as limitações físicas da estrutura existente às equipes de projeto. Por outro lado, estas mesmas limitações podem apresentar oportunidades para o projeto, pois, eventualmente, podem oferecer espaços com dimensões maiores que os projetos contemporâneos, o que favoreceria a atualização dos sistemas prediais.

Além disso, outra oportunidade que se nota em empreendimentos de reabilitação, do ponto de vista de projeto, é o fato da estrutura construída possibilitar a simulação imediata, em escala real, do que se quer projetar. Esse piloto pode colaborar com as simulações das soluções de projetos, sistemas construtivos, componentes e materiais, submetendo-os às condições reais de utilização.

Como estudado, é necessária uma abordagem diferenciada para empreendimentos de reabilitação, por parte do empreendedor e projetista. Essa revisão do conceito deve estar presente, inclusive, no modelo de contratação de empresas projetistas. Além da adequação do escopo contratual às demandas específicas da reabilitação (acompanhamento e revisão das soluções de projeto durante a execução das obras, interface com equipes de obra etc.), o modelo de contratação das empresas de projeto deve ser compatível com essa dedicação, de maneira a garantir a sua participação na etapa de obras.

Da mesma forma, a contratação dos serviços de execução das obras não pode se deter em índices de produtividade e consumo de materiais de obras utilizados em empreendimentos "novos" ou convencionais. Há a necessidade de adaptação dos recursos (materiais, mão-de-obra, equipamentos etc.) previstos, para que não haja desequilíbrios nos contratos, quando da execução das obras de reabilitação. 
A experiência anterior em empreendimentos de reabilitação de empresas de projeto, consultorias, construção, subempreiteiros etc. foi notada como positiva para empreendimentos de reabilitação, principalmente de consultores especializados. Entretanto, não se trata de uma restrição para contratação, uma vez que a modalidade de contratação adequada pode suprir a falta de experiência e a ineficiência de determinado fornecedor, sem comprometer gravemente o resultado do empreendimento.

A integração das equipes de projeto e obra foi notada como o entrave principal da interface entre as diferentes áreas. Se por um lado, a participação da equipe de obras, desde o início do empreendimento (diagnóstico e estudo de viabilidade), como fornecedora de dados de entrada para elaboração de projetos, subsidia o desenvolvimento dos projetos, por outro lado, na etapa de execução das obras, a cada interferência entre projeto e estrutura existente identificada, a equipe de obras se torna dependente das soluções de projeto, que podem acabar determinando o ritmo de execução das obras de reabilitação.

No tocante à execução das obras, o aparecimento dos elementos-surpresa (algo não previsto inicialmente na etapa de diagnóstico) foi identificado como o mais importante entrave. Por diversas razões, discutidas neste trabalho, essas intercorrências influenciam diretamente o andamento das atividades no canteiro de obras.

Para amenizar a queda de produtividade gerada pelas eventuais paralisações, entende-se que o papel do coordenador de projetos pode colaborar, imprimindo velocidade às decisões de projeto, na solução dos problemas apresentados na etapa de execução das obras. A interlocução (que deve ser desempenhada pelo coordenador de projetos) entre as áreas de projeto e obra deve ser estabelecida de maneira que a resposta da equipe de projetos não prejudique o cronograma da obra e, principalmente, não permita que seja delegada à equipe de obras a responsabilidade sobre as soluções de projeto.

Principalmente no caso de empreendimentos de reabilitação mais complexos, o coordenador de projetos pode desempenhar um papel fundamental para o sucesso 
do empreendimento. Quando é envolvido no empreendimento desde o seu início, pode atuar como um agente integrador das equipes, que poderá contribuir para que o objetivo final do empreendimento seja alcançado. Durante a etapa de execução das obras de reabilitação, o coordenador de projetos será o ponto focal da área de projetos para orientar as decisões demandadas pela equipe de obras.

Durante a realização deste trabalho, percebeu-se o potencial do tema para o desenvolvimento de pesquisas complementares. A gestão de projetos aplicada à reabilitação de edifícios pode ser estudada com diversos enfoques, dentre eles:

- aprofundar o estudo sobre custos de obras de reabilitação, envolvendo o custo de aquisição do imóvel e da intervenção de reabilitação;

- traçar um comparativo entre o custo de operação das edificações reabilitadas e o custo original de operação para analisar o real retorno do investimento de reabilitação;

- estudar a valorização dos imóveis reabilitados no mercado imobiliário das grandes cidades;

- analisar a relação entre os projetos de revitalização urbana das cidades e o investimento privado na reabilitação de edifícios;

- estudar a contribuição para a desqualificação do entorno causada por uma edificação degradada e o impacto da mesma edificação após a sua reabilitação;

- quantificar a dedicação de um coordenador de projetos para um empreendimento de reabilitação e compará-la à dedicação a projetos novos. Analisar se os perfis dos profissionais devem ser diferentes.

- quantificar os custos de execução de serviços não previstos em projetos de reabilitação.

- realizar um estudo sobre o estado da arte da reabilitação nas cidades brasileiras, mapeando os empreendimentos reabilitados e compilando as melhores práticas de gestão de projetos. 


\section{REFERÊNCIAS BIBLIOGRÁFICAS}

APPLETON, J. Reabilitação de edifícios antigos: patologias e tecnologias de intervenção. Amadora: Orion, 2003. p.146.

ARANTES, E. C. Diretrizes para reabilitação de edifícios - uso residencial em áreas centrais: o bairro de Santa Cecília. 2001. 182 f. Dissertação (Mestrado) Instituto de Pesquisas Tecnológicas, São Paulo, 2001.

AUSTRALIA ICOMOS. The Australia ICOMOS charter for the conservation of places of cultural significance. Victoria: Australia ICOMOS and Deakin University, 1999. Disponível em: <http://www.icomos.org/australia/burra.html>. Acesso em: 16. nov. 2007.

BARRIENTOS, M. I. G. G. Retrofit de edificações: estudo de reabilitação e adaptação das edificações antigas às necessidades atuais. 2004. 189 f. Dissertação (Mestrado) - Faculdade de Arquitetura e Urbanismo, Universidade Federal do Rio de Janeiro, Rio de Janeiro, 2004.

$\therefore$ QUALHARINI, E. L. Intervenção e reabilitação nas edificações. In: CONGRESSO DE ENGENHARIA CIVIL, 5., 2002, Juiz de Fora. Anais... Rio de Janeiro: Internciências, 2002.

.; QUALHARINI, E. L. Retrofit de construções: metodologia de avaliação. In: ENCONTRO NACIONAL DE TECNOLOGIA DO AMBIENTE CONSTRUÍDO, 10., 2004, São Paulo. Construção sustentável: construccion sostenible. São Paulo, 2004. 1 CD-ROM.

.; QUALHARINI, E. L. Retrofit de construções frente à ótica brasileira. In: ENCONTRO SOBRE CONSERVAÇÃO E REABILITAÇÃO DE EDIFÍCIOS, 3., 2003, Lisboa, Portugal. Actas... Lisboa: Laboratório Nacional de Engenharia Civil, 2003. v. 2, p.1007.

BARROS, L.; KOWALTOWSKI, D. Recycling existing buildings stock in city centers for housing: the need for directives. In: INTERNATIONAL CONFERENCE ON PASSIVE AND LOW ENERGY, 18th., 2001, Florianópolis. Proceedings... Florianópolis: Organizing Committee of PLEA'2001, 2001. 1 CD-ROM.

BOMFIM, V. C. Os espaços edificados vazios na área central da cidade de São Paulo e a dinâmica urbana. 2004. 2 v. Dissertação (Mestrado) - Escola Politécnica, Universidade de São Paulo, São Paulo, 2004. 
BONANNI, M. C.; SERRA, G. Reciclagem de edifícios: uma metamorfose sustentável. In: SEMINÁRIO INTERNACIONAL NUTAU'2000 TECNOLOGIA \& DESENVOLVIMENTO; CONGRESSO IBÉRICO DE ENERGIA SOLAR, 10; CONGRESSO IBERO-AMERICANO DE ENERGIA SOLAR, 5., 2000, São Paulo. Resumos. São Paulo: NUTAU-USP, 2000. p. 100.

CHOUCAIR, G. Brasileiro precisa de 8 milhões de casas. O Estado de Minas, 24 nov. 2007. Economia. p.19.

CATARINO, J. M.; SILVA, V.; PAULO, P. MatTEC - sistema de apoio à decisão na reabilitação de construções. In: CONSTRUÇÃO 2001 - CONGRESSO NACIONAL DA CONSTRUCAO, 2001, Lisboa, Portugal. Anais... Lisboa, Portugal: IST, 2001. v. 1, p. 281-288.

CONSERVATION DU PATRIMOINE ARCHITECTURAL DE LA VILLE DE GENÈVE, Departement des affaires culturelles, 1999. Disponível em: <http://www.villege.ch/geneve/amenagement/patrimoine/glossaire>. Acesso em: 16.12.2007.

COELHO, A. L. A conservação e reabilitação de edifícios na perspectiva da segurança contra-incêndio. In: ENCONTRO SOBRE CONSERVAÇÃO E REABILITAÇÃO DE EDIFÍCIOS, 3., Lisboa, Portugal. Actas... Lisboa: Laboratório Nacional de Engenharia Civil, 2003. v. 2, p.795.

CONVENTION EUROPEENNE DE LA CONSTRUCTION METALLIQUE. Fiche d'information n. 02, Acier non protégé. Publication technique, code n. 82, 1995.

CROITOR, E.P.N.; OLIVEIRA, L.; MELHADO; S.B. Etapa de diagnóstico de um projeto de reabilitação: estudo de um caso francês. In: WORKSHOP BRASILEIRO DE GESTÃO DE PROCESSO DE PROJETO NA CONSTRUÇÃO DE EDIFÍCIOS, 7., 2007, Curitiba, PR. Anais... Curitiba, 2007. 7 p.

CUSHMAN WAKEFIELD SEMCO. Painel de negócios: retrofit vale a pena! 2005. Sindicato da Habitação, São Paulo, 2005.

DUCAP, V.M.B.C.L.; ORIOLLI, A.; QUALHARINI, E. L. Considerações sobre manutenção e reabilitação predial frente às questões de auto-sustentabilidade. In: CONSTRUÇÃO 2001 - CONGRESSO NACIONAL DA CONSTRUÇÃO, 2001, Lisboa, Portugal. Anais... Lisboa, Portugal: IST, 2001. v. 2, p. 761. 
EUROCONSTRUCT CONFERENCE, 61., 2006, Amsterdam. Press release. EIB Economisch Instituut voor de Bouwnijverheid. Amsterdam, 2006. Disponível em: <http://www.euroconstruct.org/pressinfo/pressinfo.php>. Acesso em: 04 mar. 2007.

EUROCONSTRUCT CONFERENCE, 62., 2007, United Kingdom. Country report: Austria. United Kingdom, 2007. p. 33. Disponível em: $<$ http://www.euroconstruct.org/publications/publications.php $>$. Acesso em: 17 nov. 2007.

FABRICIO, M. M. Projeto simultâneo na construção de edifícios. 2002. 350 f. Tese (Doutorado) - Escola Politécnica, Universidade de São Paulo, São Paulo, 2002.

; MELHADO, S. B.; GRILO, L. M. Coordenação e coordenadores de projetos: modelos e formação. In: WORKSHOP BRASILEIRO DE GESTÃO DE PROCESSO DE PROJETO NA CONSTRUÇÃO DE EDIFÍCIOS, 3., 2003, Belo Horizonte, MG. Anais... Belo Horizonte, 2003. 7 p.

FERREIRA, A. B. H. Minidicionário da língua portuguesa. Rio de Janeiro: Nova Fronteira, c1977. 506 p.

FERREIRA, P. Prédios abandonados: moradia para baixa renda no hipercentro. Belo Horizonte, MG, 2006. p. 20.

FLORES, I.; BRITO, J. Manutenção em edifícios correntes: estado atual do conhecimento. In: CONSTRUÇÃO 2001 - CONGRESSO NACIONAL DA CONSTRUÇÃO, 2001, Lisboa, Portugal. Anais... Lisboa, Portugal: IST, 2001. v. 2, p. 737.

FONTENELLE, E. Estudos de caso sobre a gestão do projeto em empresas de incorporação e construção. 2002. 369 f. Dissertação (Mestrado) - Escola Politécnica, Universidade de São Paulo, São Paulo, 2002.

FRANÇA, Loi MOP - Loi relative à la maîtrise d'ouvrage publique et à ses rapports avec la maîtrise d'oeuvre privée. Arrêté du 21.12.1993 précisant les modalités techniques d'exécution des éléments de mission de maîtrise d'oeuvre confiés par des maîtres d'ouvrage publics à des prestataires de droit privé - Annexe II, Paris, 1993.

FRANÇA, Code de la construction. Partie réglementer, articles R111 - 11e édition, 2005 . Disponível em: <http://www.legifrance.gouv.fr>. Acesso em 15.07.2007. 
FREITAS, V. C.; SOUZA, M. Reabilitação de edifícios - do diagnóstico à conclusão da obra. In: ENCONTRO SOBRE CONSERVAÇÃO E REABILITAÇÃO DE EDIFÍ́CIOS, 3., Lisboa, Portugal. Actas... Lisboa: Laboratório Nacional de Engenharia Civil, 2003. v. 2, p.1157.

FUNDAÇÃO SEADE/CDHU. Programa de atuação em cortiços - PAC: município de São Paulo - setores básicos de intervenção. São Paulo, 2002. 87p.

- Retratos: histórias e esperanças de famílias atendidas pelo PAC. São Paulo, 2002. 48p. (Cadernos do PAC; 1).

HEITOR, T.; ALEGRE, A. Programas de reabilitação de conjuntos habitacionais células I e II das casas de rendas econômicas do Bairro de Alvalada. In: CONSTRUÇÃO 2001 - CONGRESSO NACIONAL DA CONSTRUÇÃO, 2001, Lisboa, Portugal. Anais... Lisboa, Portugal: IST, 2001. v. 2, p. 705.

LANA, M. V.; ANDERY, P. R. P. Integração de projeto-produção: um novo paradigma cultural. São Carlos, SP. 2001. 5p. Disponível em: < http://www.lem.ep.usp.br/gpse/es23/anais/INTEGRAO PROJETOPRODUCAO NOVO PARADIGMA.pdf $>$. Acesso em: 23.mar.03.

LANZINHA, J. C. G.; FREITAS, V. P.; GOMES, J. P.C. Metodologias de diagnóstico e intervenção na reabilitação de edifícios. In: CONSTRUÇÃO 2001 - CONGRESSO NACIONAL DA CONSTRUÇÃO, 2001, Lisboa, Portugal. Anais... Lisboa, Portugal: IST, 2001. v. 2, p.753.

LINDSEY, A. et al. Edifício São Vito. São Paulo: EPUSP, 2004. 17p. Trabalho prático da disciplina de Planejamento Urbano.

LUCINI, H. C. Gestão da complexidade: o projeto de recuperação de edificações existentes: requalificação urbana e novos assentamento de interesse social. São Paulo: FAU/USP, 1996. 7 p.

LUFT, C. P. Pequeno dicionário da língua portuguesa. 3. ed. São Paulo: Scipione, 1987. 591p.

MANSO, M. A. Modelo de sistema de gestão e coordenação de projetos em empresas construtoras e incorporadoras. 2006. 146 p. Dissertação (Mestrado) Instituto de Pesquisas Tecnológicas, São Paulo, 2006. 
MANUAL de escopo de serviços para coordenação de projetos: indústria imobiliária (versão 1.1). São Paulo, SP: SECOVI, 2006. Disponível em: $<$ http://www.manuaisdeescopo.com.br/Main.php?do=Inicial>. Acesso em: 17 nov. 2007.

MEDEIROS, H. Projetos integrados. Techne, São Paulo, n.109, p. 47, abr. 2006.

MELHADO, S. B. Coordenação e multidisciplinaridade do processo de projeto: discussão da postura do arquiteto. In: WORKSHOP NACIONAL DE GESTÃO DO PROCESSO DE PROJETOS NA CONSTRUÇÃO DE EDIFÍCIOS, 2., 2002, Porto Alegre. Anais... Porto Alegre, 2002. 4 p.

et al. Coordenação de projetos de edificações. São Paulo: Nome da Rosa, 2005. 115 p.

Qualidade do projeto na construção de edifícios: aplicação ao caso das empresas de incorporação e construção. 1994. 294 f. Tese (Doutorado) - Escola Politécnica, Universidade de São Paulo, São Paulo, 1994.

.; AGOPYAN, V. O conceito de projeto na construção de edifícios: diretrizes para sua elaboração e controle. São Paulo, 1995. 23 p.

MODERNO dicionário da língua portuguesa. Disponível em: <http://michaelis.uol.com.brl>. Acesso em: 15 nov. 2007.

MOURA, P. et al. Restauro e reforma do Edifício Mackenzie. In: CONFERÊNCIA DE RECUPERAÇÃO, MANUTENÇÃO E RESTAURAÇÃO DE EDIFÍCIOS, 2004, São Paulo. Anais... São Paulo: Universidade Presbiteriana Mackenzie, 2004. 10 p.

NASCIMENTO, L. A.; SANTOS, E. T. O fenômeno da sobrecarga de informações em equipes de projetos. In: SEMINÁRIO DE TECNOLOGIA DA INFORMAÇÃO E COMUNICAÇÃO NA CONSTRUÇÃO CIVIL, 2., 2002, São Paulo. Anais... Porto Alegre, 2002. $20 \mathrm{p}$.

NOVAES, C. C. Diretrizes para garantia da qualidade do projeto na produção de edifícios habitacionais. 1996. 280 f. Tese (Doutorado) - Escola Politécnica, Universidade de São Paulo, São Paulo, 1996.

OLIVEIRA, D. R.; FILHO, A. Revendo diretrizes de projeto para intervenções em centros históricos: proposta para centro de capacitação técnica Tiradentes-MG. In: 
ENCONTRO SOBRE CONSERVAÇÃO E REABILITAÇÃO DE EDIFÍCIOS, 3., 2003. Actas... Lisboa, 2003. v. 2, p.803.

OLIVEIRA, M.; FREITAS, H. Informação para a decisão em projetos de obras de edificação: estudo de caso. In: ENCONTRO NACIONAL DE TECNOLOGIA DO AMBIENTE CONSTRUÍDO, 7., 1998, Florianópolis,SC. Anais... Florianópolis, SC, 1998. v. 2, p. 577-585.

PATRIMONIE DU XX EME SIECLE EN RHONES-ALPES. Dossier élaboré en 2000. Disponível em: <http://www.jp.culture.fr/rhone-alpes/dossier/jep2000/index.htm>. Acesso em: 14.out.2007.

PONTES, P. Fórmulas de revisão de preços para trabalhos de reabilitação de edifícios de habitação. In: ENCONTRO SOBRE CONSERVAÇÃO E REABILITAÇÃO DE EDIFÍCIOS, 3., 2003. Actas... Lisboa: Laboratório Nacional de Engenharia Civil, 2003. v. 2, p.1341.

PROJETO REABILITA. Diretrizes para reabilitação de edifícios para HIS: as experiências em São Paulo, Rio de Janeiro e Salvador. São Paulo, 2007. 246 f. Programa HABITARE. Disponível em: $<$ http://reabilita.pcc.usp.br/RELATORIO FINAL-REABILITA.pdf>. Acesso em: 16.nov.2007.

RÉSIDENCE "Park Hèrmes" Lyon-Villeurbanne (69). Material publicitário. Disponível em: <http://www.abeliante.com/media/id lyonvilleurbanne hermes.pdf>. Acesso em: 15 nov. 2007.

RIGHI, R.; MACHADO, P. A requalificação de edifícios na área central da cidade de São Paulo - a experiência do Hotel Jaraguá. In: CONFERÊNCIA DE RECUPERAÇÃO, MANUTENÇÃO E RESTAURAÇÃO DE EDIFÍCIOS, 2004, São Paulo. Anais... São Paulo: Universidade Presbiteriana Mackenzie, 2004. 9 p.

RODERS, A. R. G. M. M. P. Re-architecture: lifespan rehabilitation of built heritage. Eindhoven: Technische Universiteit Eindhoven, 2006. 231 p.

SAYEGH, S. Da teoria à prática. Téchne, São Paulo, n.134, p. 38, mai. 2008.

SILVA, R. R. Requisitos para projetos de requalificação de edificações preservadas: um estudo de caso na Cinelândia. 2004. 130 f. Dissertação (Mestrado) - Faculdade de Arquitetura e Urbanismo, Universidade Federal do Rio de Janeiro, Rio de Janeiro, 2004. 
TABELA de custos para manutenção e reforma. São Paulo: PINI, 2006. Disponível em: <http://construcao-engenharia-arquitetura.lojapini.com.br/>. Acesso em: 01 nov. 2007.

THOMAZ, É. Tecnologia, gerenciamento e qualidade na construção. São Paulo: Pini, 2001. 449 p.

VAZ, L. F.; VASCONCELOS, L. M. A reabilitação de edifícios de escritórios: uma opção no cruzamento da questão da habitação com a questão das áreas centrais. In: ENCONTRO SOBRE CONSERVAÇÃO E REABILITAÇÃO DE EDIFÍCIOS, 3., 2003, Lisboa. Actas... Lisboa: Laboratório Nacional de Engenharia Civil, 2003. v. 2, p.737.

WIAZOWSKI, I. Renovação e requalificação de edifícios de escritórios na região central da cidade de São Paulo: o caso do edifício São Bartholomeu. 2007. 110 f. Monografia (MBA em Gerenciamento de Empresas e Empreendimentos na Construção Civil, com ênfase em Real Estate) - Escola Politécnica, Universidade de São Paulo, Programa de Educação Continuada em Engenharia, São Paulo, 2007.

YOLLE, J. N. Diretrizes para o estudo de viabilidade da reabilitação de edifícios antigos na região central de São Paulo visando à produção de HIS: estudo de casos inseridos na Programa de Arrendamento Residencial (PAR-Reforma) Edifícios: Olga Bernário, Labor e Joaquim Carlos. 2006. 178 f. Dissertação (Mestrado) -- Escola Politécnica, Universidade de São Paulo, São Paulo, 2006. 
ANEXO A - Roteiro para entrevistas e visitas técnicas 


\section{A - Informações gerais do empreendimento}

1. Nome do empreendimento:

2. Proprietário atual:

3. Ano da construção:

4. Ano do projeto original:

5. Área do terreno:

6. Área construída (original x proposta):

7. N. ${ }^{\circ}$ unidades/ vagas garagem:

8. Tipologia original $x$ proposta (área, n. ${ }^{\circ}$ dorm. etc.):

9. Áreas comuns (original x proposta):

10. Estágio da construção antes do início da reabilitação:

11. Prazo de execução original:

12. Prazo em que a obra ficou parada:

13. Prazo de negociação da empresa:

14. Prazo para início dos projetos:

15. Prazo de obra:

16. Ficha técnica completa (original $x$ atual):

17. Público alvo do produto:

18. Valor total do investimento:

19. Valor relativo à reabilitação $\left(\mathrm{R} \$ / \mathrm{m}^{2}\right)$ :

20. Disciplinas de projeto (original $x$ proposta):

21. O que se sabe sobre a edificação original a respeito de desempenho termoacústico; eficiência energética etc.

\section{B - Histórico do empreendimento / Idealização do produto}

1. Dados do entrevistado (nome/função/tempo de casa/tempo de formado/formação/experiência profissional anterior) 
2. Histórico da empresa em projetos de reabilitação? Qual o objetivo estratégico?

3. Principal motivação para a reabilitação:

4. Como o projeto foi recebido pelo corpo técnico da empresa (obras e projetos)? E pelos projetistas?

5. Histórico do empreendimento: grupo de moradores, traçar linha do tempo.

6. A empresa comprou o imóvel dos proprietários? Explorar (Há passivos? Quais?).

7. (Se positivo) Aquisição atendeu à política de aquisição de imóveis da empresa? Como foi tratado internamente?

8. Quais alternativas para o empreendimento foram aventadas?

9. Como foi feito o estudo de viabilidade técnica? (metodologia, prazo, profissionais, custo)

10. O estado físico das edificações foi considerado na compra do imóvel? Como foi quantificada essa depreciação?

11. Foi desenhado o fluxo desse processo?

12. Solicitar fluxo do processo de gestão de projetos da empresa.

13. Solicitar imagens e documentos originais e atuais (laudos técnicos, ppts, dwgs etc.).

\section{C - Projetos - Desenvolvimento do produto}

1. Como se deu a etapa de desenvolvimento do programa de necessidades?

2. Quais disciplinas de projetos/consultores foram contratadas especificamente para esse empreendimento?

3. Foram selecionadas empresas projetistas com experiência em reabilitação? Foi importante?

4. Estimativa de recursos (prazo e custo) para projetos foi diferente do padrão de projetos da empresa? 
5. Houve alteração na rotina de coordenação de projetos?

6. Quais foram as atividades de campo da equipe de projetos? A construção estar parcialmente construída foi vista como positiva ou negativa pelos projetistas?

7. O planejamento das atividades de projeto foi diferente?

8. Interfaces de projetos: a análise crítica recebeu tratamento diferenciado? Como foi feita a compatibilização de projetos?

9. A etapa de validação de projetos foi diferente? Qual o procedimento padrão da empresa?

10. Quais foram as modalidades de contratação dos projetos? Estava no escopo o acompanhamento da execução?

11. Eles foram/estão sendo solicitados com maior freqüência que o usual?

12. Como foram feitas as maquetes, apartamento tipo etc.?

13. Qual foi a abordagem no estande de vendas? O fato de ser reabilitação afetou negativamente o lançamento?

14. Os prazos de desenvolvimento do produto foram afetados por alguma razão específica?

15. Houve alguma peculiaridade sobre a consulta a órgãos públicos, aprovação do projeto legal etc.? Como foi a reaprovação do projeto? Há alguma facilitação do poder público nesses casos?

16. Soluções técnicas: o sistema construtivo original foi mantido ou foi alterado? Quais foram as alterações significativas?

17. Quais foram as preocupações com o desempenho da edificação?

18. Quais foram as soluções relacionadas à eficiência energética da edificação? Isso foi considerado prioridade?

19. Qual foi considerada a disciplina de projeto mais crítica no desenvolvimento? 20. O que foi reaproveitado da edificação existente? Sistemas prediais? O que se sabe sobre o desempenho da edificação original? 
21. Como os projetistas reagiram ao novo desafio? Relatar casos relevantes.

\section{D - Projetos - Formalização do produto}

1. O fluxo de informações foi diferente do tradicional?

2. A empresa procurou adequar o empreendimento ao sistema da empresa ou aconteceu o inverso?

3. Utilização de extranet? Qual?

4. Houve algum conflito relevante na integração das soluções dos projetos?

5. A etapa de validação de projetos foi diferente do tradicional?

6. Os prazos foram diferentes?

7. Como foram feitas as etapas de análise das soluções técnicas e do grau de satisfação frente ao programa de necessidades?

8. Foram feitas "individualizações" nos apartamentos?

\section{E - Projetos - Detalhamento do produto}

1. Os prazos foram cumpridos?

2. O fluxo de informações foi eficiente?

3. A integração entre as partes envolvidas precisou ser diferente da tradicional?

4. A etapa de detalhamento demandou dedicação adicional por parte dos projetistas, como visitas ao local?

5. Como os projetistas reagiram ao fato?

6. Em que momento e como foram feitas as compatibilizações dos projetos?

7. Qual solução foi dada para as diferenças construtivas já executadas entre os pavimentos tipo?

\section{F - Projetos - Planejamento do produto}

1. Acompanhamento e uso dos projetos nos canteiros: como se deu?

2. A freqüência de ajustes durante a execução das obras foi maior que o usual? 
3. Qual é o papel da equipe da empresa nessa hora?

4. Como se deu a atuação das empresas projetistas?

5. Quais foram os principais momentos críticos relacionados à execução das obras?

6. Quais foram os principais entraves encontrados na execução das obras do ponto de vista de projeto? Explorar.

7. Quais as alternativas utilizadas na solução dos problemas?

8. Houve demanda específica de estreitamento das relações com a obra?

9. Quais foram as principais demandas relativas a definições de projeto por parte da obra?

\section{G - Projetos - Pós-entrega do produto}

1. O que está previsto para essa etapa?

2. O procedimento empresa será mantido ou haverá algo específico para esse empreendimento?

3. Manutenção?

\section{H - Obra}

1. Dados do entrevistado (nome/função/tempo de casa/tempo de formado/formação/experiência profissional anterior)

2. Composição da equipe da empresa (número e perfil dos profissionais):

3. A seleção da equipe atendeu a qual critério?

4. Foram selecionados profissionais com experiência em reabilitação?

5. Foi contratado algum especialista em obras de reabilitação?

6. Prazos e marcos contratuais: semelhantes aos de obras convencionais?

7. Fase dos projetos quando do início das obras?

8. Produtividade esperada foi alcançada? Qual indicador foi utilizado?

9. Que estratégia foi utilizada para ataque à obra? 
10. Quais as principais demandas da obra em relação a projetos?

11. Quais foram as principais incompatibilidades de projetos encontradas durante a execução (projeto x projeto e projeto x estrutura existente)?

12. Qual o procedimento adotado nesses casos?

13. O índice de retrabalho foi maior ou menor que em obras convencionais?

14. Houve dificuldades para compor equipe?

15. Freqüência de soluções adotadas in loco superou o padrão normal?

16. Em algum momento os projetos tiveram de ser "abandonados"?

17. Quais foram os entraves de interface entre projetos e estrutura existente?

18. Como eles foram solucionados?

19. Na sua opinião, esses empreendimentos são mais difíceis de serem conduzidos? Por quê?

20. Qual estratégia poderia ter sido adotada e não foi? Por qual razão?

21. Qual o padrão da empresa de controle de desenhos no campo? Houve alguma anormalidade?

\section{I - Comentários finais:}

1. Modelo de coordenação interna é mais eficiente nesses empreendimentos?

2. Em que momento do projeto o coordenador precisou ser mais atuante?

3. Houve desgastes excessivos por parte da equipe de projetos? Com os projetistas? Com o departamento de obras?

4. Na sua opinião, reabilitação de edifícios pode ser executada utilizando-se a mesma metodologia de obras tradicionais? Em caso negativo, por quê? Quais os principais aspectos que fundamentam a resposta?

5. Qual seria o modelo ideal de gestão de projetos de reabilitação?

6. Quais aspectos são mais relevantes: formação/capacitação da equipe de projetos; capacitação da equipe de obra; capacitação das empresas projetistas; prazo de execução; custo etc.? 
ESCOLA POLITÉCNICA DA UNIVERSIDADE DE SÃO PAULO

DEPARTAMENTO DE ENGENHARIA DE CONSTRUÇÃO CIVIL

ROTEIRO PARA ENTREVISTAS E VISITAS TÉCNICAS DOS ESTUDOS DE CASO

Empreendimento:

Empresa:

7. Quais foram as medidas tomadas pela empresa para garantir a qualidade na pós-ocupação (garantia do produto)?

8. Quais foram as lições aprendidas de projetos?

9. Quais foram as lições aprendidas de obras? 